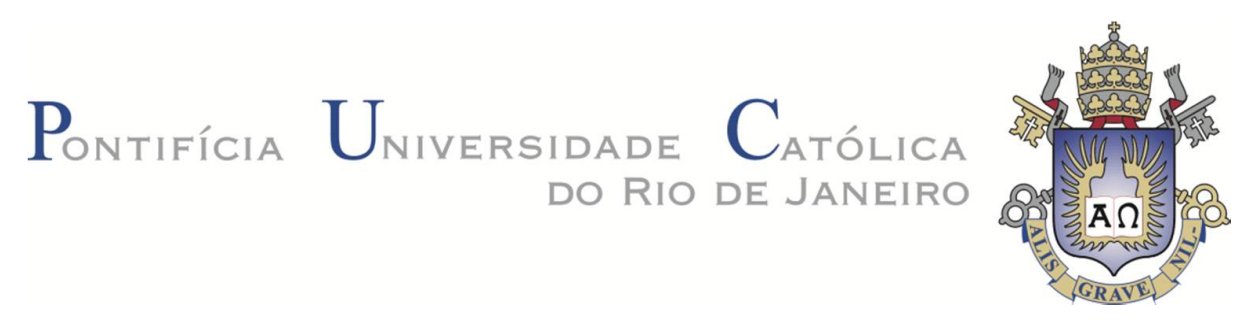

Ronise Ferreira dos Santos

\title{
Design social e produção distribuída de produtos de média complexidade para atenção básica: o caso do calçado escolar
}

\section{Tese de Doutorado}

Tese apresentada ao Programa de Pós-Graduação em Design da PUC-Rio como requisito parcial para obtenção do título de Doutor em Design.

Orientador: Prof. Alfredo Jefferson de Oliveira

Co-orientador: Profa. Lia Buarque de Macedo Guimarães

Rio de Janeiro,

Abril de 2015 


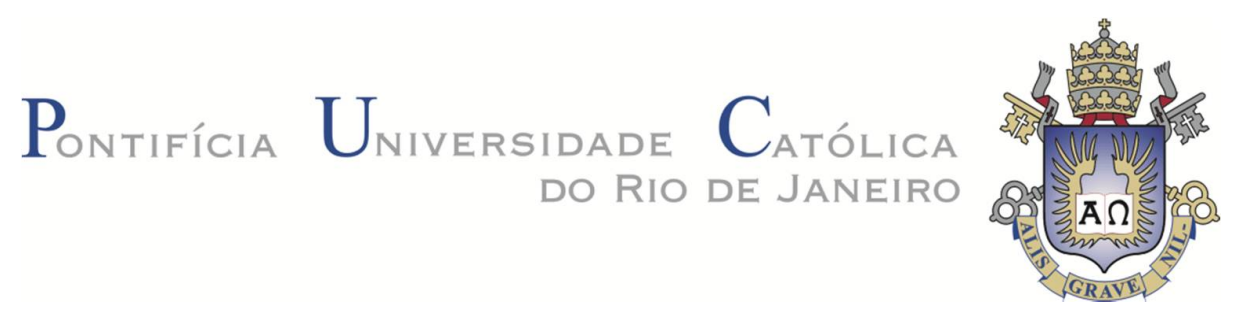

Ronise Ferreira dos Santos

\section{Design social e produção distribuída de produtos de média complexidade para atenção básica: o caso do calçado escolar}

Tese apresentada ao Programa de Pós-graduação em Design da PUC-Rio como requisito parcial para obtenção do título de Doutor em Design. Aprovada pela Comissão Examinadora abaixo assinada.

Prof. Alfredo Jefferson de Oliveira Orientador Departamento de Artes \& Design da PUC-Rio

Profa. Lia Buarque de Macedo Guimarães Co-Orientador Universidade Federal do Rio Grande do Sul

Prof. Claudio Freitas de Magalhães Departamento de Artes \& Design PUC-Rio

Profa. Chiara Del Gaudio Universidade do Vale do Rio dos Sinos

Prof. Fernando Betim Paes Leme Departamento de Artes \& Design da PUC-Rio

Prof. Luiz Antonio Meirelles Escola Técnica da Universidade Federal do Rio de Janeiro

Profa. Denise Berruezo Portinari Coordenadora Setorial do Centro de Teologia e Ciências Humanas-PUC-Rio

Rio de Janeiro, 14 de abril de 2015. 
Todos os direitos reservados. É proibida a reprodução total ou parcial do trabalho sem autorização da universidade, da autora e do orientador.

\section{Ronise Ferreira dos Santos}

Graduou-se em Design de Moda pela Universidade Veiga de Almeida em 1997, no Rio de Janeiro. Cursou a Escola Técnica do Calçado SENAI, na cidade de Novo Hamburgo, de 1999 a 2000. Especializou-se em Engenharia da Produção, ênfase Ergonomia, pela Universidade Federal do Rio Grande do Sul, em 2007. Recebeu o título de Mestre em Engenharia pela mesma instituição. É servidor técnico administrativo com lotação no Instituto de Artes da mesma instituição.

Ficha Catalográfica

Santos, Ronise Ferreira dos

Design social e produção distribuída de produtos de média complexidade para atenção básica: o caso do calçado escolar / Ronise Ferreira dos Santos; orientador: Alfredo Jefferson de Oliveira ; co-orientadora: Lia Buarque de Macedo Guimarães. - 2015.

271 f.: il.(color.); $30 \mathrm{~cm}$

Tese (doutorado)-Pontifícia Universidade Católica do Rio de Janeiro, Departamento de Artes e Design, 2015.

Inclui bibliografia.

1. Artes e design - Teses. 2. Design social. 3. Produção distribuída. 4. Desenvolvimento local. 5. Atenção básica. 6. Calçado escolar. I Oliveira, Alfredo Jefferson de. II. Guimarães, Lia Buarque de Macedo. III. Pontifícia Universidade Católica do Rio de Janeiro. Departamento de Artes e Design. IV. Título. 
Para minha filha Ana Clara luminescência de vida e amor. 


\section{Agradecimentos}

À Essência espiritual que me confiou esta missão.

Ao meu orientador Prof. Alfredo Jefferson de Oliveira por participar desta pesquisa.

A minha co-orientadora Profa. Lia Buarque de Macedo Guimarães por ter sido a mensageira e parceira desta missão do início ao fim.

À CAPES pela bolsa de doutorado-sanduíche na Delft University of Technology.

Ao GRUPO ESPERANÇA, mulheres mães do bairro Canudos, imprescindíveis aos resultados deste trabalho.

À equipe do CRAS CANUDOS I, na pessoa da psicóloga Eloá Silva e da Assistente social Talita Venzo.

Ao Zé Carlos, já em outra dimensão, por ter sido aquele que me aproximou pela primeira vez da realidade dos alunos de baixa renda de escolas públicas do Brasil.

Ao meu supervisor durante meu período de doutorado-sanduíche, na Delft University of Technology, Prof. Jean Carel Diehl, pelo respeito e dedicação no compartilhar conhecimentos com alguém de além-mar.

À Annemarie Mink por ter discutido comigo sobre o Método em design para motivação de capacidades de ser e fazer de pessoas de baixa renda.

Aos Técnicos do Fundo Nacional do Desenvolvimento da Educação, na pessoa de Nelle Cristina e João César da Fonseca.

Ao Prof. Giuseppe Marzano, da Universidade de Quito, pelo incentivo em iniciar um processo de doutoramento. 
Aos professores da Universidade Federal do Rio Grande do Sul que contribuíram com o conhecimento adquirido: Luis Felipe Nascimento (Escola de Administração), Maria Eunice Maciel (Instituto de Filosofia e Ciências Humanas, Departamento de Antropologia), Angela Danilevicz (Escola de Engenharia PPGEProdução) e Mauricio Bernardes (PPGDesign UFRGS). Hoje grandes amigos!

A Valmira, minha MÃE, parceira de todas as horas.

A Valsíria minha tia-mãe que desde a graduação não poupou esforços para dar seu apoio.

Ao Aloisio por ter sido o companheiro amoroso, inclusive para as revisões de textos nas altas horas da noite.

Ao sobrinho querido Matheus que me conduziu, sem saber, até a fonte essencial desta tese.

Aos "Meus" pelo jeito amoroso de cada um: aos irmãos Alex e Wallace, ao Tio Hélio e Tia Vilma, as tias "H2ó" - Helô e Hinha, Luzinete, Cosme, aos sobrinhos pela alegria que transformava qualquer dúvida em certeza.

Aos amigos TODOS que foram tão pacientes e presentes na minha ausência. E àqueles que também estiveram tecnicamente presentes: Magali, Fabrício Kipper, Beth Drumm, Jairo da Costa, Mônica e Aldo Pospichill.

Aos meus colegas de trabalho da UFRGS, nas pessoas de Francisco Gomes e José Carlos de Azevedo.

Ao Prof. Alfredo Nicolaievsky e Prof. Carusto, respectivamente, diretor e vicediretor do Instituto de Artes da UFRGS que permitiram minha licença do trabalho para meu doutoramento.

Aos meus vizinhos do Hawaii (edifício que moro) - uma parceria. 


\section{Resumo}

Santos, Ronise Ferreira dos; Oliveira, Alfredo Jefferson de; Guimarães, Lia Buarque de Macedo. Design social e produção distribuída de produtos de média complexidade para atenção básica: o caso do calçado escolar. Rio de Janeiro, 2015. 271p. Tese de Doutorado - Departamento de Artes e Design, Pontifícia Universidade Católica do Rio de Janeiro.

Sob a perspectiva do design social, esta tese desenvolveu um sistema de projetação e produção distribuída (SPPD) que congrega a indústria e os meios de produção local como solução para a produção e distribuição de produtos (basicamente de segurança, higiene, proteção da saúde, auxilio na vida diária. vestuário, educação e lazer) de média complexidade para atenção básica em territórios diversos. A pesquisa iniciou pela revisão teórica sobre a dimensão da inovação tecnológica social (ITS) e as estratégias do design social para a formação de rede de atores sob a lógica da THDS (Tríplice Hélice Dupla complementares para a sustentabilidade). Na sequência, foi realizada uma investigação sobre as experiências projetuais do design social, brasileiras e holandesas, e as do movimento de tecnologia social no Brasil. Por fim, foi desenvolvido o SPPD que visa a união de empresas e artesãos para produção territorializada de forma a atender suas demandas utilizando recursos locais e assim impulsionar o desenvolvimento local. O SPPD valoriza a atuação governamental ou de agentes sociais como impulsionador da demanda, e depende da constituição de um capital social e produtivo com agentes locais, que se mostrou o maior desafio do sistema. Quando aplicado ao calçado escolar, o SPPD evidenciou o papel crucial do designer para atender os parâmetros da projetação e produção distribuída em função das particularidades de cada local.

\section{Palavras-chave}

Design social; produção distribuída; desenvolvimento local; atenção básica; calçado escolar. 


\section{Abstract}

Santos, Ronise Ferreira dos; Oliveira, Alfredo Jefferson de (Advisor); Guimarães, Lia Buarque de Macedo (Co-advisor). Social design and distributed production of medium complexity primary care products: the case of scholar shoes. Rio de Janeiro, 2015. 271p. Doctoral Thesis Departamento de Artes e Design, Pontifícia Universidade Católica do Rio de Janeiro.

From the perspective of social design, this thesis developed a designing and distributed manufacturing system (DDMS) that gathers industry and local tasks (crafts) as a solution for the manufacturing and distribution of products (basically of safety, hygiene, health protection, assistance daily, clothing, education and leisure) of medium complexity for basic care in different territories. The research started by the theoretical review of the social dimension of technological innovation (STI) and strategies of social design for the network structure of players under the logic of THDs (Triple Helix Twin to sustainability). Following these, an investigation was carried out about Brazilian and Dutch social design experiences, as well as movement of social technology in Brazil. In the end, it was developed the DDMS aiming at the union of companies and craftsmen to implement a territorialized production in order to meeting their demands using local resources and thus achieve local development. The DDMS values governmental action or social actors as demand drivers, and depends on the creation of social capital and manufacturing group with local actors, which proved to be the biggest challenge system. When applied to the scholar shoes issue, DDMS highlighted the crucial role of the designer to meeting the designing requirements and distributed manufacturing According to circumstances of each local.

\section{Keywords}

Social design; distributed manufacturing; local development; primary care; scholar shoes. 


\section{Lista de abreviaturas e siglas}

$A B$ - Atenção básica

$A B D I$ - Agência Brasileira de Desenvolvimento Industrial

ABICALÇADOS - Associação Brasileira das Indústrias de Calçados

ABNT - Associação Brasileira de Normas Técnicas

ABNT - Associação Brasileira de Normas Técnicas

APEX - Agência Brasileira de Promoção de Exportações e Investimentos

APL - Arranjos Produtivos Locais

APLIC - Arranjos Produtivos locais Intensivos em Cultura

ASA - Articulação no Semiárido Brasileiro

ASA - Articulação Semiárido Brasileiro

ASSINTECAL - Associação Brasileira de Empresas de Componentes

para Couro, Calçados e Artefatos

BTS - Banco de Tecnologias Sociais

CAGED - Cadastro Geral de Empregados e Desempregados

CATMAT - Sistema de Catalogação de Material

CB-11 - Comitê Brasileiro de Couro, Calçados e Artefatos de Couro

CDC - Código da Defesa do Consumidor

CEES - Cozinha Escolar Experimental Solar

CETEC - Fundação Centro Tecnológico de Minas Gerais

COOPFARJ - Cooperativa de Fabricantes de Calçados de Duque de

Caxias

CRAS - Centro de Referência de Assistência Social

DL - Desenvolvimento Local

DSF - Designers Sem Fronteiras

ECA - Estatuto da Criança e do Adolescente

EEx - Entidades Executoras

EJA - Educação de Jovens e Adultos

EMBRAER - Empresa Brasileira de Aeronáutica 
EN - European standard

FAO - Organização das Nações Unidas para Agricultura e Alimentação

FBB - Fundação Banco do Brasil

FGV - Fundação Getulio Vargas

FIOCRUZ - Fundação Oswaldo Cruz

Firjan - Federação das Indústrias do Estado do Rio de Janeiro

FNDE- Fundo Nacional de Desenvolvimento da Educação

IBETeC - Instituto Brasileiro de Tecnologia do Couro, Calçados e

Artefatos

IDDS - International Development Design Summitt

IDEs - Itens de demanda ergonômica

IDHM- Índice Médio de Desenvolvimento Humano Municipal

INEP - Instituto Nacional de Estudos e Pesquisas Educacionais

INMETRO - Instituto Nacional de Metrologia, Qualidade e Tecnologia

IPEA - Instituto de Pesquisa Econômica Aplicada

ITCPs - Incubadoras Tecnológicas de Cooperativas Populares

ITS - Instituto de Tecnologia Social

ITS - Instituto de Tecnologia Social

LBA - Legião Brasileira de Assistência

LCA - Avaliação de Ciclo de Vida (life-cycle analysis)

LOAS - Lei Orgânica da Assistência Social

LOPP - Laboratório de Otimização de Produtos e Processos

MDIC - Ministério do Desenvolvimento, Indústria e Comércio

MEC - Ministério da Educação

MIT - Massachussets Institute of Technology

MPE - Micro e Pequena Empresa

MPOG - Ministério do Planejamento, Orçamento e Gestão

MT - Ministério do Trabalho

NBR - Normas Brasileiras Regulamentadoras

NR's - Normas Regulamentadoras do Trabalho

OBAPL - Observatório Brasileiro de Arranjos Produtivos Locais

OMS - Organização Mundial da Saúde

OMS - Organização Mundial da Saúde

ONGs - Organizações não Governamentais 
ONU - Organização das Nações Unidas

OPAS - Organização Pan - Americana da Saúde

P\&D - Laboratórios de Pesquisa e Desenvolvimento

P1+2 - Programa Uma Terra e Duas Águas

P1MC - Programa Um Milhão de Cisternas

PAIS - Produção Agro Ecológica Integrada e Sustentável

PCP - Planejamento e Controle da Produção

PDDE - Programa Dinheiro Direto na Escola.

PDP - Política de Desenvolvimento Produtivo

PIB - Produto Interno Bruto

PIDESC - Pacto Internacional sobre Direitos Econômicos, Sociais e Culturais

PMP - Plano-Mestre de Produção

PNAE - Programa Nacional de Alimentação Escolar

PNC - Plano Nacional de Cultura

PNC - Plano Nacional de Cultura

PPGEP - Programa de Pós Graduação em Engenharia de Produção

RES - Rede de Economia Solidária

RSE - Responsabilidade Social Empresarial

RTS - Rede de Tecnologia Social

SCMSP - Suppply chain management for sustainable products

SDP - Secretaria do Desenvolvimento da Produção

SEC / MinC - Secretaria da Economia Criativa

SEDEIS - Secretaria de Desenvolvimento Econômico, Energia, Indústria e

Serviços do Estado do Rio de Janeiro

SEED - Secretaria de Estado da Educação

SENAI - Serviço Nacional de Aprendizagem Industrial

SLP - Sistema Local de Produção

SLP - Sistemas Locais de Produção

SLTI - Secretaria de Logística e Tecnologia da Informação

SME - Secretaria Municipal de Educação

SMRP - Supplier management risk and performance

SNIBrasil - Sistema Nacional de Inovação do Brasil

SPPD - Sistema de Projetação e Produção Distribuída 
SQC - Sustentabilidade, Qualidade e Custo

SUS - Sistema Único de Saúde

TA - Tecnologia Apropriada

TH - Triple Hélix

HT - Hélice Tríplice

THT - Triple Hélix Twin

THDS - Tríplice Hélice Dupla complementar para a sustentabilidade

TS - Tecnologia Social

TS - Tecnologias Sociais

UEx - Unidades Executoras das Escolas

UFRGS - Universidade Federal do Rio Grande do Sul

UNESCO - Organização das Nações Unidas para a Educação, a Ciência

e a Cultura 


\section{Sumário}

1 INTRODUÇÃO 20

1.1. Caracterização da pesquisa 28

1.2. Estrutura do trabalho 29

2 INOVAÇÕES TECNOLÓGICAS PARA ATENÇÃO BÁSICA: AS

EXPERIÊNCIAS PROJETUAIS ATUAIS E SEUS MEIOS DE PRODUÇÃO 32

2.1. A dimensão social das inovações 34

2.2. Inovação tecnológica e desenvolvimento local: os aglomerados produtivos no Brasil $\quad 41$

2.3. Cooperação entre arranjos produtivos locais brasileiros 46

2.4. A dimensão social do design sob uma visão estratégica de ação 47

2.5. Design social e inovações tecnológicas de atenção básica 51

2.6. Experiências internacionais do design social 59

2.7. Conceito de tecnologia social (TS) 64

2.8. Conclusão do capítulo 73

3 SISTEMA DE PROJETAÇÃO, PRODUÇÃO E DISTRIBUIÇÃO DE PRODUTOS DE MEDIA COMPLEXIDADE PARA ATENÇÃO

BÁSICA

3.1. Análise da situação social a ser atendida, problematização, descrição das características estratégicas, da demanda e do local do sistema (Fase 1)

3.2. Planejamento da implementação e gestão do sistema produtivo (Fase 2)

3.3. Método de projetação e produção distribuída: subsistemas de entrada, transformação, saída e retroalimentação (Fase 3) 
4 ESTUDO DE CASO: APLICAÇÃO DO SISTEMA PROPOSTO

PARA PROJETAÇÃO, PRODUÇÃO E DISTRIBUIÇÃO DO

CALÇADO ESCOLAR DA REDE DE ENSINO PÚBLICA DO BRASIL 130

4.1. Situação social a ser atendida: a Indústria calçadista brasileira e a fabricação/distribuição do calçado escolar (Fase 1)

4.2. Definição do problema (Fase 1)

4.3. Características estratégicas do SPPD do calçado escolar (Fase 1)

4.4. Demanda e local do sistema (Fase 1)

4.5. Planejamento da implementação e gestão do sistema produtivo (Fase 2)

4.6. Formação do capital social (Fase 3)

4.7. Oferta de mão de obra e insumos para o sistema de produção do calçado escolar (Fase 3)

4.8. Cadeia de suprimentos do sistema de produção (Fase 3) 169

4.9. Método em design para projeto do calçado escolar (Fase 3) 170

4.10. Conclusão do Capítulo

5 Considerações finais da tese

6 Referências

7.1. ANEXO I - Email do Diretor da Secretaria de Tecnologia e Inclusão, do Ministério da Ciência e Tecnologia, durante entrevista para esta pesquisadora

7.2. ANEXO II - MATRIZ SQC - SUSTENTABILIDADE, QUALIDADE E CUSTO

8.1. APÊNDICE I - Planilha com critérios de análise para as experiências projetuais do Brasil e do Grupo de Delft 
8.2. APÊNDICE II - Questionário aplicado às Secretarias Municipais

e Estaduais de Educação dos territórios estudados

260

8.3. APÊNDICE III - Pesquisa de campo realizada com alunos matriculados nas escolas públicas de São Paulo, Rio de Janeiro e Rio Grande do Sul (Período de 2008 a 2015)

8.4. APENDICE IV - Análise sobre as especificações técnicas à forma do calçado, contidas na Norma referente a forma de calçados

8.5. APÊNDICE V - Análise sobre as especificações técnicas sobre os modelos de tênis propostos pelo projeto da Norma referente

8.6. APÊNDICE VI - Análise sobre as especificações técnicas sobre o cabedal do calçado escolar contidas no Projeto da Norma

8.7. APÊNDICE VII - Análise sobre as especificações técnicas sobre a estrutura do cabedal - couraça, contra-forte e forro, contidas no Projeto da Norma

8.8. APÊNDICE VIII - Análise sobre as especificações técnicas sobre a montagem do cabedal (parte superior do tênis) contidas no Projeto da Norma 


\section{Lista de figuras}

Figura 1 - Estrutura da Tese $\quad 29$

Figura 2 - Formato da rede de atores do SNIBrasil

(a partir de MCT, 2010, p. 18). 38

Figura 3 - Tríplice Hélice Dupla complementar para a sustentabilidade

(THDS) (a partir de Etzkowtiz e Zhou, 2006). 39

Figura 4 - Quantidade e localização dos APL's do Brasil (OBAPL, 2014) 43

Figura 5 - Localização dos APL's de base cultural (Nicolau, 2015) 46

Figura 6 - Relações das alavancas estratégicas para impulsionar a

inovação tecnológica social (a partir de Freire, 2014). 50

Figura 7 - THDS com a inovação tecnológica social no centro das

atenções em situação ideal (desenho 1) e em situação real (desenho 2). 51

Figura 8 - Objetivos e produtos desenvolvidos por projetos brasileiros 53

Figura 9 - Itens de demanda citados pelos respondentes 57

Figura 10 - Capa dos Livros Designing for Emerging Markets - Design

of Products and Services (Kandachar et al., 2009) e Designing with

Emerging Markets: Design of Products and Services (Kandachar et al., 2011) 61

Figura 11 - Regiões atendidas pelos projetos do grupo de design and

engineering, da TU Delft, em relação a sua localização. 62

Figura 12 - Lâmpada carregada a energia solar fabricada pela Empresa

D-Light (D.light S2: The Learning Light) (Tice, 2013).

Figura 13 - Estrutura do Capítulo com as 3 grandes Fases do modelo

proposto para projetação e produção distribuída (SPPD) de produtos

de atendimento básico.

Figura 14 - Quadro comparativo entre propostas projetuais para

atendimento de necessidades básicas de populações

Figura 15 - Relação da estrutura do sistema com os três estágios de vivência do público-alvo (no topo) e representação gráfica da lógica da THDS, movidas pelas alavancas de arquitetura e reputação (Key, 1993).

Figura 16 - Prazos, atividades e objetivos para tomada de decisão no 
planejamento do sistema produtivo pela Empresa Focal.

(a partir de Tubino, 2007, p. 1). 89

Figura 17 - Passos para implementação do SPPD pela empresa focal. 93

Figura 18 - Fluxograma dos passos para implementação do sistema. 94

Figura 19 - Esquema demonstrativo da formação dos grupos sociais produtivos.

Figura 20 - Configuração do capital social do sistema pela formação de um Arranjo Produtivo Local (APL).

Figura 21 - Lista dos setores produtivos dos arranjos produtivos locais do Brasil (OBAPL, 2014).

Figura 22 - Número de APL's por índices de IDH Estaduais

Figura 23 - Número de APL's por índices de IDH Estaduais

Figura 24 - Lista de materiais sustentáveis reconhecidos como“mais licitados" pelo sistema compras Net do Governo Federal do Brasil entre 2010 e 2012.

Figura 25 - Induções da empresa focal para implementação das práticas socioambientais.

Figura 26 - Modelo para gestão da cadeia de suprimentos do sistema de produção, conforme Seuring e Muller (2008b, p. 1706).

Figura 27 - Detalhamento da estratégia para avaliação de fornecedores para riscos e desempenho. Adaptado do Modelo de Seuring e Müller (2008b, p. 1706).

Figura 28 - Gestão da cadeia de suprimento para produtos sustentáveis

Figura 30 - Lista de soluções para cada necessidade básica por tipo de produto.

Figura 31 - Esquema operacional do sistema

Figura 32 - Valores dos tênis da marca AllStar, desejado por meninas.

Preços em reais (Fonte Empresa fabricante: Coopershoes Ltda., em 2015).

Figura 34 - Configuração básica do sistema de produção do calçado escolar do Brasil.

Figura 35 - Etapas padrão do processo produtivo de calçados esportivos, femininos e botas para uso profissional da Empresa Vulcabrás (2015). 
Figura 36 - Lista dos Estados prioritários em atendimento em relação ao baixo índice de IDHM.

Figura 37 - Número de alunos matriculados, no ensino fundamental, na rede pública de ensino do município de Novo Hamburgo (INEP, 2015).

Figura 38 - Formação do Capital social do sistema de produção

Figura 39 - Fontes de coleta de dados sobre a disponibilidade de mão de obra no Brasil e nos territórios.

Figura 40 - Localização dos Polos Calçadistas Brasileiros por regiões geográficas do Brasil.

Figura 41- Distribuição de fabricantes de sola por lotes de

fornecimento do uniforme escolar definido pela FGV ao FNDE (2010).

Figura 42 - Capacidade para fabricação artesanal do calçado no Brasil

Figura 43 - Consulta no Mapeamento da indústria criativa sobre trabalhadores artesanais da confecção de calçados (Firjan, 2014).

Figura 44- No. de Trabalhadores artesanais da confecção de calçados

e artefatos de couros e peles da cidade de Novo Hamburgo (FIRJAN, 2013). 165

Figura 45 - No. de Trabalhadores artesanais da confecção de

calçados e artefatos de couros e peles/Moda da cidade de

Duque de Caxias (FIRJAN, 2013).

Figura 46 - Resultado da busca por "solado", sem a opção produto

sustentável, no sistema de catalogação de material do portal de compras governamentais - CATMAT.

Figura 47 - Uniforme distribuído pela Prefeitura de Duque de Caxias

(Fonte: SMED de Duque de Caxias, 2015).

Figura 48- Número de lotes distribuídos por regiões do País

Figura 49 - Estrutura, em número de partes, de modelo similar ao proposto pelo projeto da norma específica ao calçado escolar do Brasil (A partir de Tênis para corrida, 2015).

Figura 50 - Tênis escolar, distribuído por escolas do Município de

Duque de Caxias no Rio de Janeiro, usado durante 3 meses, com previsão para uso de 12 .

Figura 51 - Comparação visual entre a sola nova e a sola usada durante 90 dias, tênis tamanho 37-38, distribuído por escolas do Município de Duque de Caxias no Rio de Janeiro. 
Figura 52 - Distribuição de escolas por número de respondentes

Figura 53 - Ordem de citação das respostas dos 480 respondentes para a 1a .

Figura 54- Distribuição de demanda por série escolar.

Figura 55 - Requisitos desejados pelos alunos que definem o fator

Prático e sua relação com as Normas.

Figura 56 - Ficha Técnica com propostas de requisitos obrigatórios

para o método em design do calçado escolar com referência na

análise do Projeto em relação à Norma específica ao calçado escolar.

Figura 57 - Modelo de matriz para definição de matéria-prima em

relação aos fatores práticos citados pelos alunos.

Figura 58 - Matriz morfológica para definir opções de modelo do

calçado escolar

Figura 59 - Protótipo apresentado pelo grupo social produtivo,

formado pelo modelista e a fabriqueta de Novo Hamburgo.

Figura 60 - Tênis desenvolvido pelo modelista, Sr Fernando, para

fabricar com uma Família proprietária de uma fabriqueta em Canudos

- NovoHamburgo: definindo o $4^{\mathrm{o}}$. grupo social produtivo do território.

Figura 61 - Fluxograma do SPPD que o grupo social produtivo

de Novo Hamburgo experimentou.

Figura 62 - Fluxograma das fases do SPPD que o grupo social

produtivo de Duque de Caxias alcançou.

Figura 63 - Análise final sobre a Fase 1a

Figura 64 - Análise final sobre a Fase 1b

Figura 65 - Analise final sobre a Fase 1c: $1^{\text {a }}$. Característica.

Figura 66 - Análise final sobre a Fase 1c: 2ª . Característica.

Figura 67 - Análise final sobre a Fase 1c: $3^{\mathrm{a}}$. Característica.

Figura 68 - Análise final sobre a Fase 1d: sobre a demanda

Figura 69 - Análise final sobre a Fase 1d: sobre o local

Figura 70 - Análise final da FASE 2

Figura 71 - Análise final Fase 3a

Figura 72 - Análise final da fase $3 b$

Figura 73 - Análise final da fase 3c

Figura 74 - Análise final da fase 3d 


\section{1 INTRODUÇÃO}

A motivação deste trabalho é antiga, surgiu de uma reportagem sobre superfaturamento na compra de calçados escolares, realizada no ABC Paulista, no ano de 2008. Naquele ano, eu participava, como bolsista de mestrado, no Projeto CNPq Fábrica da Inclusão: pólos sustentáveis no Rio Grande do Sul sob o enfoque Zeri (Guimarães, 2008), do Laboratório de Otimização de Produtos e Processos (LOPP), da Escola de Engenharia da Produção, na Universidade Federal do Rio Grande do Sul.

A "Fábrica da Inclusão" objetivava gerar bens de consumo não duráveis (fraldas e absorventes higiênicos com celulose de casca de arroz), semiduráveis (utensílios para cozinha em vidro reciclado e cerâmica) e duráveis (micro-ônibus movido a óleo de cozinha para mobilidade local) à população necessitada, a reportagem trouxe a ideia de incorporar ao Projeto a demanda de fabricar calçados e roupas escolares para alunos da rede pública de ensino do Estado. Como tinha adquirido uma vivência acadêmica, durante o mestrado, junto ao setor coureirocalçadista, tive a oportunidade de contribuir com os estudos voltados ao calçado escolar.

Assim, a pesquisa tomou curso reconhecendo que o calçado escolar é um objeto que atende uma necessidade humana básica, pois na sua ausência, principalmente em ambientes onde populações vivem em situações precárias, seu uso é uma maneira eficaz de prevenção e proteção na transmissão de doenças, dentre elas, as doenças da pobreza que segundo a Fiocruz (2011) são:

Doenças que se relacionam, em grande parte, com as chamadas "doenças tropicais", também conhecidas como "doenças negligenciadas", e atualmente referidas pela Organização Mundial de Saúde (OMS) e pela Organização Panamericana da Saúde (OPAS), como "doenças infecciosas relacionadas à pobreza", ou simplesmente "doenças infecciosas da pobreza", tais como as geo-helmintíases ${ }^{1}$ que acometem quase $80 \%$ dos escolares dos municípios de baixo índice de desenvolvimento humano.

1 Geohelmintíases - doenças transmitidas pelo solo contaminado como: Ancilostomose, Ascaradíase, Larva migrans e o tétano. 
A pobreza e a ausência de saúde constituem um círculo vicioso em que doenças infecciosas retroalimentam a pobreza, um círculo que possui determinantes socioeconômicos que acometem, mais frequente e severamente, o contingente de brasileiros pobres, tanto adultos quanto idosos e crianças que, segundo o IPEA (2013), é de 39.150.981 de brasileiros, sendo: 10.452.383 extremamente pobres $(5,5 \%$ da população total em indigência ou miséria) e 28.698.598 pobres (15\% da população total com renda domiciliar per capita inferior à linha de pobreza). Neste contexto, o governo Brasileiro dispõe de programas assistencialistas de transferência de renda (como o Bolsa Família, por exemplo) e de subvenção de recursos para provisão de produtos e serviços de necessidade básica que não estão disponíveis ou não são acessíveis (como o uniforme escolar) para grande parte da população.

Os temas necessidade básica, direitos humanos e responsabilidade governamental trazem à discussão a diferença entre o papel do estado em conduzir ações de assistência social como medidas assistencialistas às populações vivendo carência de atenção básica. O assistencialismo e a assistência social são termos similares, mas que carregam significados bem diferentes. A diferença conceitual pode ser compreendida na análise do processo histórico de atendimento social no Brasil, desde quando os programas de governo eram exercidos pela Legião Brasileira de Assistência - LBA, período reconhecido como prestação de favores àqueles que necessitavam ajuda, portanto assistencialismo. O cenário mudou quando foi instituída a Assistência social, pela Constituição do Brasil (1988), e em seguida com a promulgação da Lei de no. 8.742, a Lei Orgânica da Assistência Social (LOAS) (1993), que regulamenta o serviço social, estabelecendo normas e critérios para sua organização, especialmente no enfrentamento da pobreza, como um direito do povo brasileiro. A LOAS dá a este direito uma conotação restritiva, pelo termo mínimos sociais, apesar de estarem referenciados aos demais direitos internacionais como: o direito à vida, o de desfrutar de um nível de vida adequado à saúde e ao bem estar humano, à proteção contra doenças e ao acesso à alimentação e educação (Declaração Universal dos Direitos Humanos, 1948, Artigo XXV; BRASIL, Decreto no. 591, Artigo 11, 1992).

É neste sentido que se justifica a proposta desta tese, de contribuir com o processo de desenvolvimento humano contínuo, em situações que, em alguns casos, como na situação de urgência, se configuram como assistencialismo, mas 
assumindo que a situação ideal seria que todos tivessem condições igualitárias de vida sustentável. Entende-se que a contribuição foca o momento atual, que ainda requer que o governo subsidie alguns itens básicos para a população mais carente, esperando, no entanto, que num futuro breve não haja mais necessidade de subvenção, pois toda a sociedade poderá arcar com os itens básicos para sua vida.

Apesar da motivação inicial desta tese ter sido a problemática social do calçado escolar, o foco são os produtos/serviços de atenção básica ${ }^{2}$, sob a perspectiva do design. O desafio é responder ao questionamento: como projetar, produzir e distribuir produtos/serviços para atenção básica de populações diversas? Para respondê-lo, foi preciso aproximação de temas que giram em torno do objeto de estudo, e correlatos entre si, sendo eles: 1. necessidades básicas, direitos humanos e responsabilidade governamental; 2. desenvolvimento humano, tecnológico e populações carentes de atenção básica e 3. desenvolvimento local e meios de produção.

Dentro do escopo da tese, o calçado é um estudo de caso, pois apesar dele ser um dos objetos de cuidado básico à segurança, higiene e à saúde dos indivíduos, é um produto caro e, portanto, muitas vezes inacessível àqueles com baixo poder de compra. Por isso, o Governo brasileiro promove a distribuição gratuita do calçado escolar para os alunos matriculados nas escolas de ensino público do Brasil, e vivendo em situação de pobreza, isto é, de famílias com rendimentos inferiores a $\$ 2$ dólares por dia, ou com renda mensal inferior a $\mathrm{R} \$$ 75,00 (setenta e cinco reais) (IPEA, 2013, p. 7).

A distribuição do calçado escolar consta do direito de acesso à Educação e obrigatoriedade escolar, instituído pela Constituição Federal (1988), no Art. 20, incisos I e II e Art. 208, $\S 1^{\circ}$. Desta forma, sua distribuição faz parte de Políticas Públicas e Medidas de Assistência Social do Governo do Brasil. O Capítulo II Dos Direitos Sociais, artigo $7^{\circ}$, inciso IV, da Constituição Brasileira de 1988, prevê o vestuário como uma das necessidades básicas a ser provida pelo salário

\footnotetext{
${ }^{2}$ Atenção básica (AB) - Conceito apropriado, nesta tese, conforme utilizado pela Política Nacional de Atenção básica (PNAB), do Ministério da Saúde no Brasil (2012, p. 9; 10; 43), significando: cuidar de indivíduos expostos a riscos e vulnerabilidades vivendo necessidades básicas [...] orientada pelos princípios da universalidade, da acessibilidade, do vínculo, da continuidade do cuidado, da integralidade da atenção, da responsabilização, da humanização, da equidade e da participação social.
} 
mínimo nacional sendo que, em se tratando de famílias em situações de desemprego, o Estado assume a responsabilidade através de seus programas de transferência de renda e assessoramento social até a condição de urgência findarse.

Desde 2003, o Fundo Nacional de Desenvolvimento da Educação - FNDE, do Ministério da Educação, realiza pregões nacionais para cadastro de preços, que apoiam os Estados e Municípios na compra e na transparência pública dos processos de aquisição do calçado escolar a ser distribuído para os alunos no nível fundamental das escolas públicas (UNDIME, 2003). No entanto, o calçado é pago pelas prefeituras a quem cabe adquirir e distribuir (ou não) este produto, a um custo médio de $\mathrm{R} \$ 25,00$ (vinte e cinco reais).

Enquanto os demais itens do uniforme são de fácil licitação, o calçado tem sido um problema ainda sem solução para o FNDE. Ele é um produto de fabricação mais complexa que os demais itens do uniforme, e depende de poucos fornecedores que podem atender as especificações do produto e o volume sazonal da demanda de um grande número de usuários necessitados em locais diversos do Brasil. Portanto, exige uma infraestrutura produtiva de inovação, pela complexidade tecnológica, principalmente do solado, e produção em grande escala, mas poderia ser projetado, fabricado e distribuído com base nos recursos disponíveis no território onde vive o grupo de usuários, para otimizar os recursos humanos e materiais locais, a logística de produção e distribuição, e atender fatores práticos, simbólicos, culturais e ambientais do produto.

Os temas desenvolvimento humano, desenvolvimento tecnológico e a demanda por produtos de atenção básica trazem uma discussão sobre como as condições de um contexto social com necessidades básicas não atendidas impulsiona inovações tecnológicas específicas. A reflexão toma como base as experiências projetuais atuais do campo do design social (DS) e das chamadas tecnologias sociais (TS). O design social é conhecido como aquele que atende demandas de populações que não têm poder de compra no mercado tradicional, enquanto as TS’s são conhecidas no Brasil como o desenvolvimento tecnológico que alia o conhecimento técnico-científico ao saber popular de um local (o capital social) para, em parceria e cooperação, solucionar problemas. Tanto o DS como a TS estão focados nas demandas tecnológicas para atendimento de melhores condições de alimentação, educação, energia, habitação, renda, recursos hídricos, 
saúde e meio ambiente (Margolin e Margolin, 2002; ITS, 2007, p. 19; FBB, 2015). As soluções podem compreender produtos, técnicas ou metodologias, que necessariamente sejam reaplicáveis em outros contextos sociais que, segundo Albuquerque (2003), tornam-se eficazes quando respeitam as características de cada território, considerando tanto os recursos quanto as demandas sócioeconômico-ambientais, portanto, direcionadas a contribuir com o Desenvolvimento Local (DL), uma modalidade de desenvolvimento que:

[...] pode ser concebido como um processo orientado e promovido a partir do território, no qual são introduzidas inovações, sejam elas técnicas ou sociais. Descrito como o conjunto de ações visando aumento na criação de valor e na economia, pela geração de trabalho, renda, melhoria no bem-estar e qualidade de vida dos moradores (Albuquerque, 2003).

Contudo, salienta Sachs (2004), sendo o DL um processo orientado a partir do território, com a intenção de que suas inovações, técnicas ou sociais, alcancem a melhoria do bem-estar e qualidade de vida das pessoas locais, é importante observá-lo a partir de várias dimensões, como as sociais (igualdade de direitos), culturais (valorização dos conhecimentos tradicionais), políticas (governança democrática), econômicas (alocação e gerenciamento mais eficiente dos recursos) e ambientais (preservação dos recursos naturais). Há também que se perceber o modo de produção no entorno deste processo de DL e, neste sentido, Santos (2000) aponta que sua infraestrutura produtiva é construída a partir das particularidades de cada território como:

[...] mudadas as condições políticas, é nesse espaço banal que o poder público encontraria as melhores condições para sua intervenção. [...] tratase, aqui, da produção local de uma integração solidária, obtida mediante solidariedades horizontais internas, cuja natureza é tanto econômica, social e cultural como propriamente geográfica. A sobrevivência do conjunto, não importa que os diversos agentes tenham interesses diferentes, depende desse exercício da solidariedade, indispensável ao trabalho e que gera a visibilidade do interesse comum (Santos, 2000, p. 53).

A análise de Santos (2005) mostra que não importa o interesse entre os diversos agentes sociais da sociedade civil local, mas o aspecto de cidadania na ação articulada entre eles, que depende a sobrevivência do grupo para os rumos que querem dar ao seu futuro e ao do seu território. Para Feitosa $(2009$, p.11;12), tal movimento entre agentes sociais traduz uma forma de desenvolvimento regional denominado endógeno, entendido por Amaral Filho (1999, p. 2) como: 
[...] um processo de crescimento econômico que implica uma contínua ampliação da capacidade de agregação de valor sobre a produção, bem como da capacidade de absorção da região, cujo desdobramento é a retenção do excedente econômico gerado na economia local e/ou a atração de excedentes provenientes de outras regiões. Esse processo tem como resultado a ampliação do emprego, do produto e da renda do local ou da região.

Como modelos de desenvolvimento endógeno, pode-se elencar aqueles constituídos pelos sistemas que determinam intensas aglomerações de empresas, fabricando o mesmo produto ou gravitando em torno de uma produção típica, como os sistemas locais de produção, os arranjos produtivos locais, os arranjos produtivos locais intensivos em cultura ou os arranjos produtivos locais de artesanato (REDESIST, 2011; Matos, 2013).

A reflexão permite uma visão de desenvolvimento em que modos e meios de produção diferentes não precisam ser excludentes entre si, tendo oportunidades de cooperação, em que juntos se enquadrem recursos das experiências de cada realidade em prol das demandas do território. Sob a perspectiva do design, a estratégia é garantir um envolvimento de ideias compartilhadas e de bem estar social (Meroni, 2008, p. 35).

Uma situação muito próxima ao que se discutiu acima, respeitando suas diferenças, principalmente no que tange aos anseios de desenvolvimento tecnológico integrado, já vem acontecendo na cadeia de produção de empreendimentos solidários, conforme citado em uma das reuniões do Fórum Municipal de Empreendimento Solidário, da cidade de Novo Hamburgo (2015), do qual a pesquisadora participa. Alguns empreendedores declararam que tal situação é compreendida por eles, como solução diante a falta de opção por fornecedores de insumos dentro da economia solidária, ao contrário da disponibilidade de ofertas dinâmicas da indústria de capital. Apesar de não conseguirem trocas por comércio justo, as partes têm conseguido descontos nos valores das compras, o que vem funcionando muito bem.

Este envolvimento de agentes sociais em prol de um bem comum, também se manifesta na cultura de projeto, caracterizada pela abordagem de co-design que motiva as diversas manifestações e expertises dos atores integrantes de um grupo (Sanders e Stappers, 2008, p. 8; Meroni, 2008, p. 35). Neste estudo, as soluções projetuais ou desenvolvimento de inovações tecnológicas ocorrem por meio de rede de atores formada pela lógica da Tríplice Hélice Dupla complementar para a 
sustentabilidade $^{3}$ (Etkowitz e Zhou, 2006), ou como Senhoras (2008) cita, cooperação e o envolvimento de agentes produtivos da indústria (de larga escala) com agentes da produção de pequena escala ou de ofícios tradicionais locais, para garantir um processo de inovação tecnológica responsável por atender as necessidades das pessoas, gerar renda e não impactar o ecossistema. Isto levaria ao fortalecimento do que o Instituto de Tecnologia Social - ITS chama de condição primeira para o início de uma ação de desenvolvimento local: a construção de um capital social de agentes integrados (ITS, 2007, p. 19).

Discutir e refletir sobre os assuntos envoltos na temática desta pesquisa motivou a hipótese de que um sistema de produção distribuída, que congregue a indústria e os meios de produção local (artesanato utilitário) é uma solução para a fabricação de produtos de atenção básica de brasileiros de territórios diversos. Os produtos considerados são aqueles que geralmente pertencem ao escopo do design: bens de consumo duráveis e semi-duráveis, de média complexidade tecnológica para atender necessidades básicas de segurança, higiene, proteção da saúde, auxilio na vida diária, vestuário, educação e lazer

Ao pensar o território, é importante colocar em evidência a lógica ecoeficiente do sistema, ou seja, conseguir produzir sempre melhor, na quantidade suficiente, com menores recursos, menos resíduos, cuidando e satisfazendo as necessidades das pessoas, sem deixar de promover a redução dos impactos ambientais e gerar trabalho e renda.

Desta forma, tem-se como objetivo desenvolver um sistema de projetação, produção e distribuição local de produtos que contribua no atendimento de algumas necessidades básicas de populações carentes e de localização diversa, considerando a redução dos impactos ambientais e sociais deste sistema. Este deve compreender o conjunto de atividades, interrelacionadas, considerando as riquezas (humanas, materiais e técnicas) do

\footnotetext{
${ }^{3}$ Tríplice Hélice Dupla complementar para a sustentabilidade: é uma lógica de ação dos atores sociais envolvidos com a inovação tecnológica que detém o formato de Tríplice Hélice Dupla complementar (governo-empresa-universidade e governo-sociedade-universidade), que incorpora o conceito de sustentabilidade para que processos de produção possam ser repensados quando as políticas públicas são insatisfatórias no controle de crises complexas da sociedade (Etzkowitz \& Zhou, 2006) (Capitulo II, item 2.1).
} 
território como os inputs de seus subsistemas (de entrada, transformação, saída e retroalimentação) dentro de uma lógica ecoeficiente de produção. Contando que o sistema seja replicável em diversos contextos, estas riquezas derivam das ofertas locais de matérias-primas, habilidades de profissionais de ofícios tradicionais (artesanato utilitário) e da tecnologia industrial por meio de cooperação social e tecnológica entre os meios industriais de produção em larga escala e os meios de produção local, inclusive os artesanais.

Para testar o sistema, esta tese toma como estudo de caso de aplicação, a problemática social de projetação, produção e distribuição do calçado escolar, um objeto para atenção básica, principalmente importante para alunos da rede de ensino pública do Brasil, pertencentes a camada da população de menor renda. É um item que requer atenção imediata por parte dos responsáveis pela educação pública, pois são de uso diário, o mais caro do uniforme escolar, o mais valorizado pelos usuários, e também o que implica em mais dificuldades de aquisição pelo governo.

Com a intenção de cumprir com os objetivos gerais desta pesquisa, são os seguintes os objetivos específicos:

1. Investigar experiências do campo do design que tenham atendido necessidades humanas básicas por meio do desenvolvimento de um produto/serviço;

2. Investigar experiências em tecnologias sociais brasileiras que desenvolveram produtos/serviços de atenção básica;

3. Investigar o cenário socioeconômico da problemática social envolta na especificação de compra e distribuição do calçado escolar para a rede de ensino público do Brasil;

4. Desenvolver um sistema de projetação, produção e distribuição local de produtos de média complexidade para atenção básica, focando um mínimo de impactos ambientais e sociais;

5. Experimentar o sistema-piloto considerando a problemática do calçado escolar. 


\section{1. Caracterização da pesquisa}

Esta pesquisa, do ponto de vista de seus objetivos, é exploratória, pois visa proporcionar maior familiaridade com as temáticas envoltas no problema, para torná-lo mais explícito. Por sua natureza, caracteriza-se como pesquisa teórica e aplicada, pois tem como objetivo fundamental o interesse na aplicação e utilização prática dos conhecimentos gerados (Gil, 2002), através do desenvolvimento do um sistema de projetação, produção e distribuição local de produtos que atendam necessidades básicas da população de baixa renda.

Segundo Gil (2002), o delineamento e os procedimentos técnicos desta pesquisa são de cunho: (i) bibliográfico, pois suas fontes referenciais foram livros e artigos científicos; (ii) de levantamento, pois foram coletadas informações de experiências de grupos acadêmicos significativos, de pessoas e instituições da sociedade civil relacionadas ao objeto de pesquisa; (iii) de estudo de caso, tendo sido elencado o contexto de distribuição do calçado escolar no Brasil, como objeto de estudo, e por fim (iv) experimental, diante sua natureza de pesquisa aplicada por proposições práticas pela experimentação do sistema desenvolvido.

A forma de abordagem do problema, desenvolvimento da pesquisa e suas proposições estão sustentados por uma metodologia de pesquisa-ação (Thiollent, 2011) que permite conduzir os objetivos de cunho social, com atuação direta da pesquisadora e cooperação dos atores sociais envolvidos no contexto.

Assim, o método de trabalho foi estruturado por seis etapas: $1^{\mathrm{a}}$ etapa definição do problema: como projetar, produzir e distribuir produtos para atenção básica de populações diversas; $2^{\mathrm{a}}$ etapa - investigar experiências projetuais de design social e tecnologias sociais que tenham desenvolvido objetos de atenção básica; descrever o modo e os meios dos sistemas de produção configurados para operacionalizar estas ações; descrever as especificidades das experiências analisadas; $3^{\mathrm{a}}$ etapa - desenvolver o sistema de projetação, produção e distribuição de produtos que atendam necessidades básicas de populações carentes; descrever suas vantagens e desafios; e $4^{\mathrm{a}}$ etapa - elaboração do plano de ação da pesquisa: experimentação piloto do sistema, considerando a problemática social sobre a produção e distribuição do calçado escolar para alunos da rede pública de ensino fundamental do Brasil. Como recortes ao campo de pesquisa foram definidos dois 
Municípios: Duque de Caxias, no Estado do Rio de Janeiro, e Novo Hamburgo, no Estado do Rio Grande do Sul; descrição do experimento e dos resultados alcançados pelos grupos executores em cada território.

\section{2.}

\section{Estrutura do trabalho}

Esta tese foi desenvolvida em 5 capítulos, conforme a figura 1 que apresenta sua estrutura.

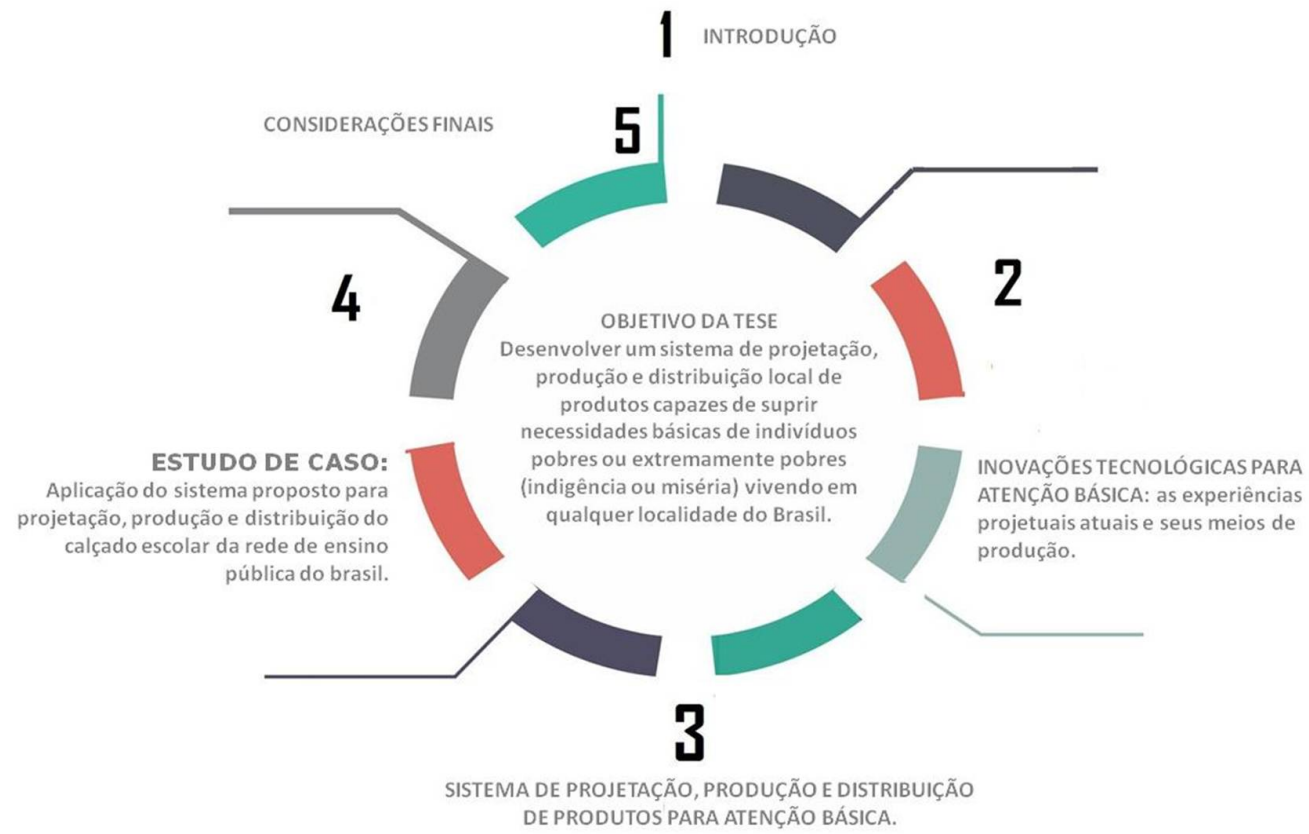

Figura 1 - Estrutura da Tese

O Capitulo I configura-se por esta INTRODUÇÃO que traz uma aproximação ao tema, do objeto de estudo e dos objetivos a serem alcançados com o desenvolvimento deste estudo de pesquisa.

O Capítulo II apresenta uma reflexão sobre a dimensão social da inovação e da inovação tecnológica; sobre os modos de cooperação entre meios de produção industrial e artesanal local para projetação, produção e distribuição de produtos sustentáveis que venham suprir necessidades básicas de uma camada da população. Focou-se produtos que podem ser classificados como: de grande escala, porque devem atender um grande numero de usuários; e local, porque devem ser projetados, fabricados e distribuídos com base nos seguintes requisitos projetuais: utilizar recursos disponíveis no território onde vive o grupo de 
usuários, atender fatores práticos, ambientais, simbólicos e culturais, além de contribuir com o desenvolvimento local.

O capitulo II também apresenta experiências projetuais do design social, nacionais e estrangeiras, e da tecnologia social, especialmente aquelas que desenvolveram produtos para suprir carências básicas de populações. Buscou-se compreender destas experiências: o planejar, o projetar, o fabricar e a logística de distribuição dos produtos, bem como os impactos causados nas cinco dimensões da sustentabilidade (SACHS, 2004) que contribuem para o desenvolvimento local: social, cultural, política, econômica e ambiental. Como fonte de pesquisa para busca de projetos, foram consultados banco de dados sobre o tema, vinculados a instituições de ensino e pesquisa, nacionais e estrangeiras; organizações nãogovernamentais (ONG's) e governamentais, e empresariais, como Fundações e ateliês de design que possuem como atividade fim o projeto de produtos para design social, tecnologia social e desenvolvimento local.

Quanto aos projetos estrangeiros, vinculados ao campo do design, definiu-se como fonte principal de busca o banco de dados do grupo de pesquisa do Departamento de design e sustentabilidade, da Delft University of Technology, instituição de ensino holandesa, onde a pesquisadora realizou o estágio de doutorado-sanduíche, no período de Dezembro de 2014 a março de 2015, com fomento da CAPES. A parceria de trabalho foi definida em função do número de projetos já realizados e os resultados publicados, bem como pelo interesse dos pesquisadores da Delft University of Technology em participar e contribuir com os propósitos desta tese.

O Capitulo III apresenta o processo de desenvolvimento da proposta desta tese: o sistema de projetação, produção e distribuição de produtos/serviços de atendimento de necessidades básicas, considerando os conhecimentos gerados nos capítulos anteriores.

O Capitulo IV apresenta a aplicação do sistema de produção desenvolvido no Capitulo III, utilizando como referência o cenário socioeconômico descrito pelos atores sociais envolvidos com a problemática do estudo de caso desta tese: o calçado escolar da rede pública de ensino do Brasil. As informações foram coletadas entre 2008 e 2015, a partir de uma amostra extraída das populações de cada ator social envolvido no contexto. 
O Capitulo V apresenta as considerações finais e propostas de trabalhos futuros. 


\section{2 INOVAÇÕES TECNOLÓGICAS PARA ATENÇÃO BÁSICA: AS EXPERIÊNCIAS PROJETUAIS ATUAIS E SEUS MEIOS DE PRODUÇÃO}

Este capítulo tem por finalidade organizar os conhecimentos fundamentais ao desenvolvimento do sistema proposto por esta tese. A fim de cumprir seus propósitos foram realizados: a) um estudo teórico sobre a dimensão social da inovação tecnológica, a partir de seus formatos institucionalizados; b) uma investigação sobre os métodos de projetação, fabricação e distribuição de produtos configurados por experiências de desenvolvimento tecnológico social do campo do design, e do movimento de Tecnologia Social, que abrange propostas de diversas áreas do campo científico.

Desta forma, a estrutura do capítulo, em primeiro momento, ao apresentar uma reflexão teórica sobre a dimensão social da inovação tecnológica, mostra que o sentido da inovação vem se ampliando quando os formatos de rede de atores inserem a sociedade como ator e passam a valorizar todas as dimensões da sustentabilidade e a conduzir suas estratégias de ação. A inclusão deste novo ator aos formatos de rede permite ampliar a visão da inovação tecnológica, de produtos e processos para competitividade, para a inovação de caráter social.

Em seguida, mostra-se o campo do design sob a perspectiva de seus modelos e propósitos para o desenvolvimento tecnológico social, considerando as estratégias e métodos de suas experiências projetuais nacionais e estrangeiras. $\mathrm{O}$ levantamento e a coleta de dados sobre as experiências estrangeiras aconteceram durante o período de doutorado-sanduíche, que a pesquisadora realizou junto ao grupo de pesquisa do Design for Sustainability Department, da Delft University of Technology.

Na sequência, apresenta-se as experiências em tecnologia social no Brasil, reconhecidas como um movimento de inovação por desenvolvimentos tecnológicos sociais. 
Sua característica estratégica principal é gerar o conhecimento compartilhado entre os saberes e fazeres tácitos e técnico-científicos, e difundi-los na sociedade. Ao final, concluindo o capítulo, é apresentado um condensado de informações sobre as reflexões teóricas quanto as análises das experiências projetuais.

O método de pesquisa deste capítulo é de cunho qualitativo e quantitativo, pois foram consideradas abordagens, não numéricas e numéricas, à identificação e compreensão das informações. Foram realizadas atividades exploratórias para o levantamento, coleta e descrição dos dados. Como procedimento técnico nas investigações, adotou-se pesquisas do tipo:

- bibliográfica, nas bases de dados disponibilizadas pela biblioteca da PUCRio, da CAPES e demais bases de livre acesso. A coleta priorizou artigos publicados, em periódicos científicos, livros publicados por grupos de pesquisa da área em estudo, ou em correspondência multidisciplinar sobre o tema.

- levantamento de campo, envolvendo o contato direto com pessoas que estavam relacionadas aos grupos de pesquisa em design (no Brasil e no exterior) como: coordenadores dos projetos identificados ou seus representantes, técnicos de instituições governamentais (instância federal, estadual e municipal) e representantes de Organizações não governamentais.

- documental, para consultas locais dos relatórios dos projetos desenvolvidos pelos alunos da Delft University of Technology (TU DELFT).

Para operacionalizar a investigação dos projetos, foram definidos 33 critérios, organizados em 5 grupos, seguindo uma estrutura por modelo de Gestão do processo de desenvolvimento de produto (Rozenfeld et al, 2006; Ulrich e Eppinger (2000); Clark e Wheelwright (1993)). Os grupos definidos foram: Grupo 1 - Dados identificadores / demográficos do projeto; Grupo 2 - Dados do Planejamento estratégico do projeto; Grupo 3 - Dados metodológicos do projeto, Grupo 4 - Dados sobre o desenvolvimento do produto; e Grupo 5 - Pósdesenvolvimento e resultados do Projeto. O apêndice I apresenta a lista de critérios organizados pelo grupo a que pertencem, bem como a descrição qualitativa de cada um dos critérios. 


\section{1. A dimensão social das inovações}

Muitos países vivem ambientes econômicos baseados no conhecimento e caracterizados por mercados competitivos, e para transpor o desafio de estar em desenvolvimento constante, a inovação ${ }^{4}$ surge como solução. Em especial, as inovações tecnológicas, que sempre estiveram relacionadas ao desenvolvimento econômico de uma nação, mensurando o quanto uma nação é ou não desenvolvida em relação à outra. Entretanto, a literatura mostra que uma nação desenvolvida não é aquela que possui progresso econômico, mas aquela que prioriza as demais dimensões do contexto social para manter uma condição sustentável aos seus cidadãos (Sen ${ }^{5}, 2000 ;$ Sachs $^{6}, 2004$, p. 38). Um alto PIB não retrata uma nação desenvolvida se ela tem uma grande taxa de pobreza e miséria.

A inovação é fator primordial ao progresso das organizações empresariais, conceitualmente entendida desde a Revolução industrial (Harvey, 2012, p. 26) e sustentada, pela visão de Schumpeter (1934 apud Harvey, 2012, p. 26), como fator determinante da evolução econômica e do impulso dos ciclos do capitalismo em momentos de crise (OCDE, 1997, p. 21; Figueiredo, 2005, p. 54).

Apesar da massiva concentração de ações e incentivos para o desenvolvimento tecnológico industrial, quer em processos quer em produtos/serviços, as inovações podem ocorrer via conhecimentos diversos, como os tácitos (pessoal e específico ao contexto social) ou codificados (sistematizados e de desenvolvimento tecnológico). Na pré-história, o ser humano já inovava, prolongando suas capacidades com o fazer de artefatos e maneiras próprias de viver em seus ambientes pela necessidade de subsistência (Leroi-Gourhan, 2007, p. 113). Na contemporaneidade, identificam-se modelos via artesanato utilitário

${ }^{4} \mathrm{O}$ termo inovação foi cunhado no âmbito da OCDE nos anos 70 com vistas a promover uma interação mais efetiva entre o setor produtivo e as áreas de Pesquisa e Desenvolvimento (P\&D). Isso ocorreu no momento em que a abertura de mercados e o aumento da competitividade internacional incitaram empresas e governos a estabelecerem sinergias envolvendo pesquisa tecnológica e política industrial, para a manutenção das taxas de crescimento econômico (Andrade, 2006, p. 142).

${ }^{5}$ Amartya Sem (1999) acredita que desenvolvimento econômico implica na expansão das capacidades humanas ou no aumento da liberdade dos indivíduos.

${ }^{6}$ Ignacy Sachs (2004, p. 38) diz: existe um desenvolvimento includente e um crescimento excludente ou concentrador, a maneira de definir desenvolvimento includente é por oposição ao padrão de crescimento perverso, conhecido na bibliografia latino-americana como excludente do mercado de consumo e concentradorm(de renda e de riqueza). 
(populares), grupos sociais (comunidades criativas), organizacionais (empresariais), acadêmicos (universidades) e mercado (marketing) (Andrade, 2006, p. 148; Bignetti, 2011, p. 4).

A inovação como processo social pode ser definida, segundo Machado (2006) como:

[...] um conjunto complexo que compreende e associa dispositivos técnicos, saberes e saber-fazer, como certa apreensão do estado da arte e dos problemas que permanecem em aberto; uma representação dos métodos disponíveis ou pertinentes para resolver esses problemas, certo número de ideias sobre as lições a serem tiradas das experiências passadas e sobre o futuro possível ou provável das tecnologias.

Assim a tecnologia se apresenta, essencialmente, como o saber que pode ser incorporado em artefatos, ou desincorporado em relação aos artefatos, mas incorporado na prática cotidiana de todos os atores envolvidos com o desenvolvimento tecnológico. Esse saber pode ser próprio a um grupo de atores, citando Pinch e Bijker (1984 apud Machado, 2006), uma empresa ou um setor industrial, conforme Nelson e Winter (1982 e 1977 apud machado 2006), ou ter um alcance mais geral, como para Dosi (1982 apud Machado, 2006) onde ele toma a forma de "paradigmas tecnológicos".

Os países que priorizam a inovação como fator primordial de apoio à indústria, integram as políticas de desenvolvimento econômico às de ciência e tecnologia, estruturadas por arranjos institucionais (Albuquerque, 2004, p.10), os chamados Sistemas nacionais de inovação, que são uma medida institucional globalmente utilizada que tem o papel de planejar estrategicamente as ações pelos cenários identificados. Segundo Freeman (1987 e 1995 apud IEIS, 2013), este sistema é:

[...] o conjunto de relações exercidas por diversos atores que formam um conjunto de instituições contribuindo para o progresso tecnológico dos Estados, que consequentemente, determina o desenvolvimento socioeconômico.

Este conceito proporcionou a compreensão de que os diferentes níveis de crescimento da economia estavam associados à capacidade de inovação tecnológica de cada País. Freeman (1987), Lundvall (1992), Nelson (1993) e Edquist (2001) (apud Albuquerque, 2004) identificaram fatores econômicos, políticos e culturais que influenciam as ações dos sistemas nacionais de inovação no que tange a determinação da escala, da direção e do sucesso alcançado pelas inovações. Entretanto, os quatro autores concordam sobre a importância da ação coordenada entre as diferentes instituições para criar e motivar o surgimento das 
dinâmicas de inovações sociais e econômicas. Dentre outras vantagens, há a redução dos custos dos investimentos, porque a integração dos atores permite que suas competências e especializações se complementem criando um ambiente propício e favorável à inovação (Senhoras, 2008, p. 139). Machado (2006) acredite ser ainda mais:

[...] cada ator tem sua própria definição do que é "vantajoso", ou, dito de outro modo, dos objetivos gerais que ele se fixa e que podem ser o lucro econômico para uma empresa privada [...] Pinch e Bijker (1984 apud Machado, 2006) insistem que a lista dos atores envolvidos, o que eles chamam os relevant social groups, é específico de cada inovação e assume um caráter estratégico no desenvolvimento das inovações: são eles que definem os problemas aos quais a inovação deve trazer uma resposta.

Esta estrutura planejada determina que os processos de inovação sejam realizados de forma sistematizada, por desenvolvimentos tecnológicos, assumindo a ciência como gênese da tecnologia. Entretanto, Senhoras (2008, p. 139) e Carvalho (2009, p. 111) mostram que este fenômeno do desenvolvimento institucional e da inovação, realizado por meio do conhecimento gerado de forma compartilhada nas redes de atores, possui diferentes formatos de combinação de atores, e chamam atenção para aqueles em que participam a universidadeempresa-governo.

No modelo do Triangulo de Sábato ${ }^{7}$ o governo apenas computa tais resultados como apoio socioeconômico às demandas da sociedade onde ele deveria atuar e não consegue atingir. São exemplos os projetos desenvolvidos pelas universidades (que desenvolvem a tecnologia) que são financiadas e utilizadas pelas empresas (organizações empresariais). Este modelo é semelhante aos modelos evolutivos da Tríplice Hélice (TH), propostos por Etzkowitz e Leydesdorff (1998), mas no TH, diferente do Triângulo de Sábato, o Governo não é passivo, pois atua integrado aos demais atores, universidades e empresas, e seu papel é de regulador, fonte de informações oficiais e fomentador da atividade.

No Brasil, o Sistema Nacional de Inovação (SNI) mostra que os projetos seguem a lógica do formato $\mathrm{TH}$, composto pelo formato de atores governoempresa-universidade, sendo a universidade o ator essencial do sistema de

7 Sábato, J.A. \& Botana, N. La ciencia y la tecnología en el desarrollo futuro de America Latina. In: Sábato, J.A. (comp.). El pimsamiento latinoamericano en la problemática cienciatecnología-desarrollo. Buenos Aires, Editorial Paidos, 1975. 
inovação para alcançar padrões de produção técnico-científica de países desenvolvidos. No entanto, Czelusniak et al, (2010, p. 12) questionam o modo como se introduziu tal formato no Brasil, porque não foi levado em consideração as diferenças estruturais da sociedade brasileira em relação a sociedade que originou o formato. Isto configura um contra senso em relação às propostas dos autores do modelo $\mathrm{TH}$, que compreendem que cada país deve atender suas características para utilizar o modelo. Na ausência de um ambiente político, econômico e social conformado, tal como dos países desenvolvidos, fica faltando a condição para que o desenvolvimento social e o bem estar da sociedade possam advir do desenvolvimento econômico. Todavia, afirma IEIS et al. (2013) que ainda que tenham ocorrido através da importação de tecnologia estrangeira, os planos de desenvolvimento tecnológico começaram a se fortalecer, no Brasil, desde a década de 90.

O Sistema Nacional de Inovação do Brasil (SNIBrasil) segue o modelo TH tendo o governo como gestor, detendo o papel de articular ações para a inovação através das políticas públicas de Desenvolvimento Produtivo, de Educação, de Desenvolvimento da Agropecuária, de Saúde e de Defesa. Já a gestão é guiada pelo Plano de Ação de Ciência, Tecnologia e Inovação (PACTI), de forma participativa e compartilhada entre os atores, com propósitos de distribuição de recursos e conhecimento em todo território nacional pelo sistema de C, T\& I (MCT, 2010, p. 18). O grupo de atores é formado: pelo Governo Federal e suas agências de fomento e apoio à pesquisa; pelo Governo Estadual e suas secretarias e agências de amparo à pesquisa e pelas grandes agências de pesquisas e regulamentações, universidades, Empresas e Centros de Pesquisa, conforme a figura 2. 


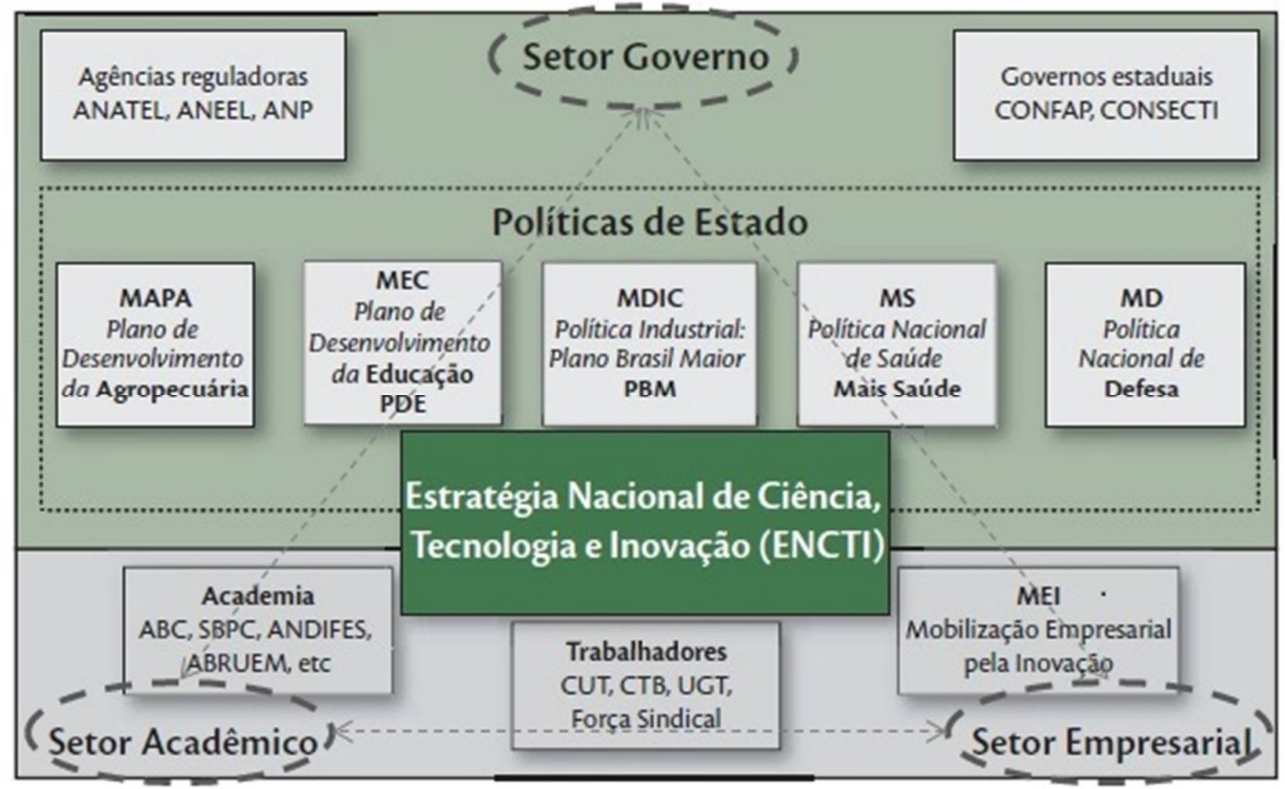

Figura 2 - Formato da rede de atores do SNIBrasil (a partir de MCT, 2010, p. 18).

O potencial de contribuição da inovação tecnológica para o desenvolvimento econômico de uma nação é inegável, mas há como ampliar o seu sentido, concebendo-a por valores contidos no processo histórico-social de cada sociedade e, transcendendo a visão onipresente de produtividade por competitividade, na oferta de bens e serviços (Andrade, 2006). Um argumento que se fortalece quando a inovação se faz imprescindível como apoio em momentos de crises complexas da sociedade, quando as estruturas existentes e as políticas estabelecidas são insatisfatórias na eliminação das desigualdades sociais, das questões da sustentabilidade, das mudanças climáticas e da epidemia mundial de doenças crônicas e ciclos de pobreza e miséria (Murray et al., 2010). Nestes momentos, seus formatos de ação para o bem estar social são obrigados a projetar para além da dimensão econômica, abrigando, em igual teor, as dimensões social, cultural, política e ambiental (Sachs, 2004; Schultz, 1987, p. 64).

Nesse sentido, Etzkowitz e Zhou (2006) incorporam o conceito de sustentabilidade nos seus formatos de Tríplice Hélice, fazendo entender que a inovação envolve tal conceito, para que processos de produção possam ser repensados com a incorporação de requisitos ambientais e sociais. Desta forma, os autores apresentam o seu último modelo de Tríplice Hélice Dupla (THD), com dois conjuntos de Hélices tríplices que se complementam: universidade indústria - Governo e Governo-Universidade-Público (figura 3). 


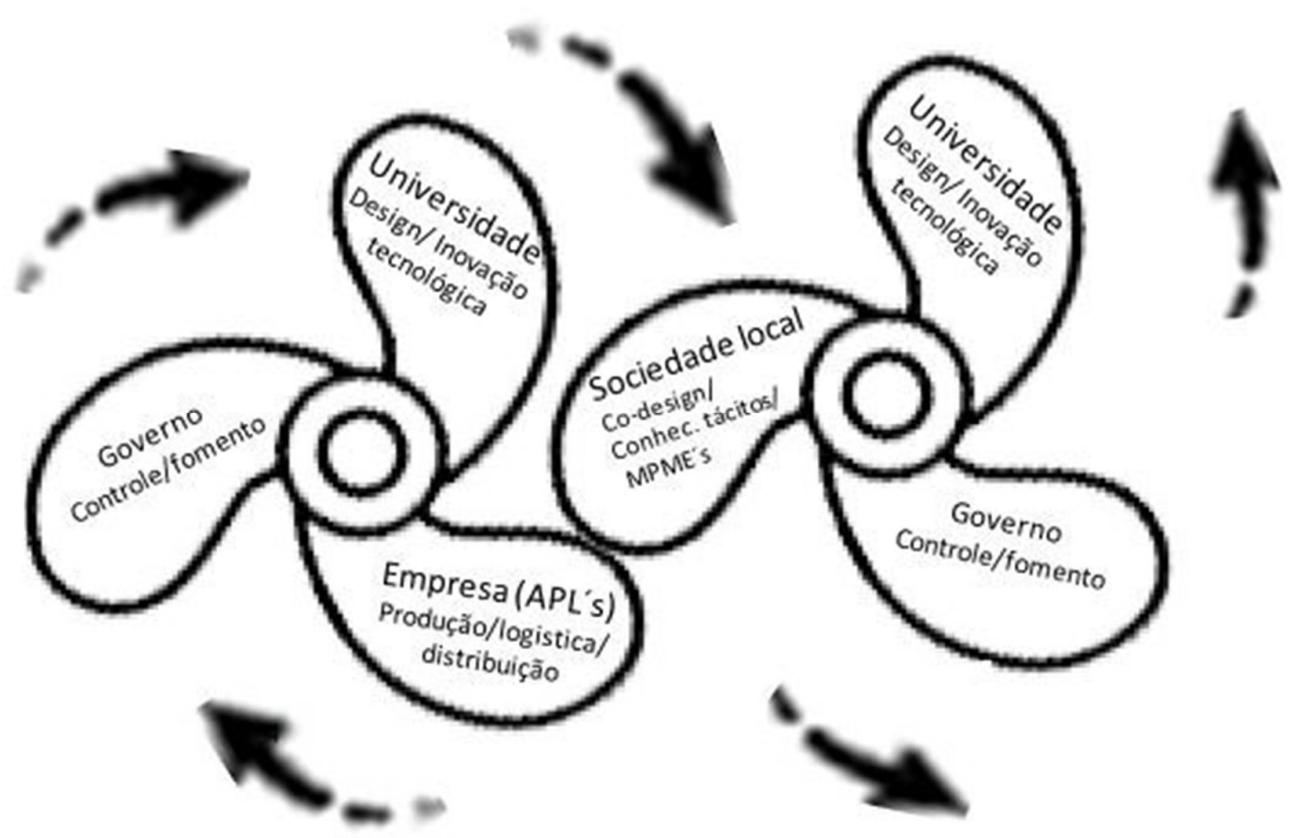

Figura 3 - Tríplice Hélice Dupla complementar para a sustentabilidade (THDS) (a partir de Etzkowtiz e Zhou, 2006).

Senhoras $(2008$, p.141) propõe que a sociedade brasileira remodele a lógica de TH, para um formato de tríplice hélice público social, com viés crítico de ativismo científico e tecnológico para a inclusão social, o que ampliaria o potencial de desenvolvimento da inovação tecnológica. Se a proposta fosse absorvida pelo SNIBrasil, suas ações poderiam responder às necessidades sociais (problemas sociais complexos, regionais e específicos) e ao mesmo tempo inserir a indústria (por suas empresas) de forma competitiva no mercado.

Nesse contexto, surge a inovação social ${ }^{8}$ como uma das formas de se buscar alternativas viáveis para o futuro da sociedade humana, tendo como meta as novas formas de fazer as coisas, por empoderamento individual e consequentemente do coletivo, para satisfazer necessidades sociais. Uma ferramenta para solucionar problemas territoriais locais, diante a inação do Estado (Cloutier, 2003; Dees et al., 2004; Mulgan et al., 2007; Moulaert et al., 2007; Santos, 2009).

Murray et al (2010, p. 3) diz que a inovação social tem propósitos de bem viver para os indivíduos e coletividades através de novas ideias, em produtos, sistemas ou serviços, que servem para aumentar a capacidade colaborativa de ação

${ }^{8}$ Segundo Cloutier (2003) os primeiros autores a apresentarem reflexoes sobre inovação social foramTaylor e Gabor (1970). 
das pessoas, as chamadas iniciativas "de baixo para cima", ou seja, que partem dos cidadãos e do meio ambiente vivido, ao invés de ser uma iniciativa de governos e organizações empresariais.

No campo do design, inovação é entendida como a maneira de um coletivo de pessoas solucionar situações em prol do bem comum e do planeta. Manzini (2008, p. 45) afirma que é o revelar de um novo perfil de sociedade, passando de um comportamento de consumo para outro de acesso às experiências no uso de bens comuns, deixando de existir a direta relação de que bem-estar significa mais produtos fabricados, para uso individualizado: um comportamento do fazer junto ou participativo. Já Tenório (1990, p.2) esclarece que é uma prática social que o ser humano repensa e confronta o seu saber e suas experiências com os saberes dos demais interlocutores do grupo.

O Open Book of Social Innovation, publicado pela The Young Foundation mostra a importância que as pessoas têm no processo de inovação tecnológica, pela consciência e intenção de criar alternativas e respostas aos grandes desafios de nosso tempo à qualidade de vida (Murray et al, 2010, p. 3). Segundo André e Abreu (2006), a inovação quanto às ações diretas com propósitos de mudança social, liga-se por três atributos, simultaneamente, sendo eles: a) o da satisfação de necessidades humanas não satisfeitas pelo estado e pelo mercado tradicional; b) o da inclusão social; e c) o da capacitação de agentes ou atores como sujeitos aptos, empoderados, a superar a exclusão social e disseminar mudanças por grupos sociais (comunidades, movimentos ativistas, como a economia solidária e o comércio justo), centros acadêmicos e empresas sociais.

Bignetti (2011, p. 4; 6) salienta que apesar das diferenças de foco entre inovação tecnológica e inovação social, tal dicotomia não é excludente, portanto podem estar imbricadas no desenvolvimento tecnológico sistematizado, quando muitas outras soluções para a sociedade poderão acontecer pela aplicação do conhecimento gerado das duas vertentes (Pereira, 2000; Mulgan et al 2006: 4; 5). Muitas inovações tecnológicas já possuem caráter social, e inovações sociais já lançam mão da tecnologia no emprego das chamadas tecnologias sociais. Contudo, para (Bignetti, 2011; p.4), a gestão da inovação social se diferencia da gestão tecnológica e sua condução requer modelos distintos dos tradicionais modelos desenvolvidos para a gestão tecnológica. A inovação tecnológica social é o resultado do conhecimento aplicado, por um grupo de informações técnico 
cientificas e tácitas, que de forma participativa focam em soluções como necessidades sociais.

Para (Feitosa, 2009, p. 11; 12), tal movimento entre agentes sociais traduz uma forma de desenvolvimento regional denominado endógeno, entendido por Amaral Filho (1999:2) como:

[...] um processo de crescimento econômico que implica uma contínua ampliação da capacidade de agregação de valor sobre a produção, bem como da capacidade de absorção da região, cujo desdobramento é a retenção do excedente econômico gerado na economia local e/ou a atração de excedentes provenientes de outras regiões. Esse processo tem como resultado a ampliação do emprego, do produto e da renda do local ou da região.

Segundo Santos (2000) seria nesse espaço banal, o território, que o poder público encontraria as melhores condições para sua intervenção e subvenção.

Este fazer da inovação, com propósitos ao desenvolvimento regional, pauta-se na valorização da geração de conhecimento tecnológico endógeno de forma compartilhada. Um movimento estratégico para formação de redes com capilaridade no ambiente social local tentando ampliar a eficiência coletiva para obter vantagens, contando com as competências e especializações das experiências de cada agente, que de forma isolada não seria possível atingir (Albuquerque, 2004, p. 10; Tidd, Bessant e Pavitt, 2008, p. 23; Vieira, 2009, p. 19).

Como modelos de desenvolvimento endógeno, pode-se elencar aqueles constituídos pelos sistemas que determinam intensas aglomerações de empresas, fabricando o mesmo produto ou gravitando em torno de uma produção típica, como os sistemas locais de produção, os arranjos produtivos locais e os arranjos produtivos locais intensivos em cultura.

\section{2 . \\ Inovação tecnológica e desenvolvimento local: os aglomerados produtivos no Brasil}

De acordo com Suzigan (1999), partindo da matriz histórica marshalliana ${ }^{9}$, mas incorporando olhares de diferentes disciplinas e abordagens, existe,

9 As vantagens da aglomeração de produtores foram inicialmente apontadas por Marshall (1982), a partir da experiência dos distritos industriais da Inglaterra no século XIX, procurando compreender como a concentração de firmas em uma mesma região poderia 
atualmente, uma ampla literatura sobre aglomerações produtivas. $\mathrm{O}$ primeiro nome identificado, por pertencer à categoria de "sistema de produção" e pelas ações de abrangência local, é Sistema Local de Produção (SLP) definido pela Redesist $^{10}$ (2011) como:

[...] um aglomerado ${ }^{11}$ de constituição natural formado por agentes econômicos, políticos e sociais, localizados em um mesmo território, que apresentam vínculos consistentes de articulação, interação, cooperação e aprendizagem. Incluem não apenas empresas - produtoras de bens e serviços finais, fornecedoras de insumos e equipamentos, prestadoras de serviços, comercializadoras, clientes e suas variadas formas de representação e associação - mas também outras instituições públicas e privadas voltadas à formação e treinamento de recursos humanos, pesquisa, desenvolvimento e engenharia, promoção e financiamento.

Um aglomerado de agentes integrados com a magnitude e consistência de vínculos de um SLP compreende que sua constituição e vínculos tenham origem em um processo histórico e atemporal da atuação organizada, cooperativa e integrada com base nas relações dos indivíduos e nos recursos específicos do lugar, ou seja, do território (Poletto, 2009; Amaral Filho, 2011, p. 192).

Exemplo similar ao conceito de Sistema Local de Produção (SLP) é o de Arranjo Produtivo Local (APL) que, segundo Paiva (2002, p. 1; 2), significa o processo de sistematização do desenvolvimento de aglomerações produtivas locais, que quando consolidado transforma-se em um SLP. É por este motivo que a REDESIST (2011) adota o termo e o conceito de APL, para apontar SLP's não inteiramente constituídos, ou seja, quando as articulações entre os agentes locais ainda não estão suficientemente desenvolvidas para caracterizá-las como sistema. Contudo, a definição teórica de APL's divulgada pela REDISIT (2003) e

prover, ao conjunto de produtores, vantagens comparativas que não seriam verificadas se eles estivessem atuando isoladamente (Suzigan, 1999).

${ }^{10}$ REDESIST - é uma rede de pesquisa interdisciplinar, formalizada desde 1997, sediada no Instituto de Economia da Universidade Federal do Rio de Janeiro e que conta com a participação de várias universidades e institutos de pesquisa no Brasil, além de manter parcerias com outras organizações internacionais, tendo como principal foco de pesquisa os arranjos e sistemas produtivos locais (Observatório de APL's, 2011).

${ }^{11}$ Aglomerado ou Aglomeração - A especialização de um determinado "sítio" (que pode ser uma rua de um bairro, um bairro de uma cidade, uma cidade de uma região, ou uma região de um estado) em uma determinada atividade (Paiva, 2002, p. 2). 
considerada pelo Observatório Brasileiro de Arranjos Produtivos Locais (OBAPL,2011) é:

Arranjos produtivos locais são aglomerações territoriais de agentes econômicos, políticos e sociais - com foco em um conjunto específico de atividades econômicas - que apresentam vínculos mesmo que incipientes. Geralmente envolvem a participação e a interação de empresas - que podem ser desde produtoras de bens e serviços finais até fornecedoras de insumos e equipamentos, prestadoras de consultoria e serviços, comercializadoras, clientes, entre outros - e suas variadas formas de representação e associação. Incluem também diversas outras organizações públicas e privadas voltadas para: formação e capacitação de recursos humanos, como escolas técnicas e universidades; pesquisa, desenvolvimento e engenharia; política, promoção e financiamento.

No Brasil, o Grupo de trabalho de APL do Observatório dos Arranjos Produtivos Locais tem a atribuição de elaborar e propor diretrizes gerais para a atuação coordenada do governo no apoio a arranjos produtivos locais em todo o território nacional (figura 4).

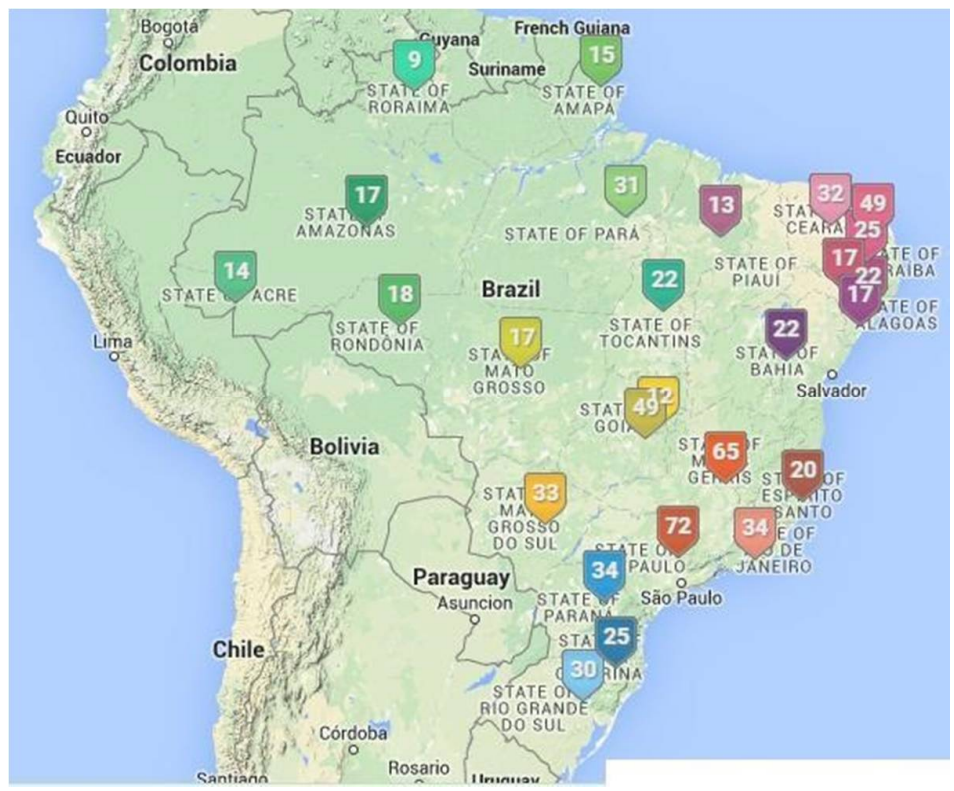

Figura 4 - Quantidade e localização dos APL's do Brasil (OBAPL, 2014)

Os APL's possuem duas características de formação que os distinguem em duas categorias: a de Arranjos produtivos locais industriais (OBAPL, 2011), e a de Arranjos produtivos Locais de base cultural (Matos, 2013), ou por APL's intensivos em Cultura, como são denominados pelo Ministério da Cultura e o Ministério do Desenvolvimento da Indústria e do Comércio (MDIC) (2013). Os APL's industriais se formam a partir da aglomeração e cooperação de empresas de 
mesma atividade econômica, e os APL's intensivos em cultura são formados por indivíduos com mesma habilidade tradicional e conhecimento tácito ${ }^{12}$. Entretanto, as duas categorias apresentam mesma especialização produtiva com agentes pertencentes ao mesmo território.

\subsection{1.}

\section{APL's de artesanato e ofícios tradicionais}

Nas atividades culturais, a forma de conhecimento mais importante é aquela associada à qualidade de atividades culturais. Este é um conhecimento essencialmente tácito, que se manifesta na forma de habilidades dos agentes. Os conhecimentos associados às práticas, rotinas e habilidades são difíceis de serem codificados e transferidos, mas têm um papel primordial para o sucesso inovativo nas mais variadas atividades produtivas (Cassiolato e Lastres, 1999). O que é específico às atividades culturais é o fato de o mesmo conjunto de conhecimentos tácitos e habilidades de uma pessoa constituir o principal insumo, o processo produtivo e o próprio produto resultante.

A concepção de cultura, neste estudo, está relacionada com as atividades econômicas geradoras de bens e serviços, tomando-se como referência inicial a definição da Organização das Nações Unidas para a Educação, a Ciência e a Cultura (United Nations Educational, Scientific and Cultural Organization UNESCO)(2004) sobre as atividades culturais. Elas são relativas:

[...] à criação, produção, e comercialização de conteúdos que são intangíveis e culturais em sua natureza. Estes conteúdos estão protegidos pelo direito autoral e podem tomar a forma de bens e serviços. São indústrias em trabalho e conhecimento e que estimulam a criatividade e incentivam a inovação dos processos de produção e comercialização.

O conceito de Arranjo Produtivo Local (APL) que não prioriza a intensidade competitiva de mercados formatados por modelos organizacionais para desenvolvimento regional, com base no desenvolvimento sustentável e qualidade de vida configura um APL de concepção cultural. Segundo Matos (2013), configura-se como Arranjo Produtivo Local de base cultural e desenvolvimento,

${ }^{12}$ Conhecimento tácito - é aquele que o indivíduo adquiriu ao longo da vida, pela experiência. O conhecimento tácito não é formalizado, não podendo ser facilmente transferido. Este tipo de conhecimento é constituído pelas crenças, valores, saberes e habilidades ou competências dos agentes e organizações (Cohendet e Steinmueller, 2000). 
determinantes de competitividade e sustentabilidade, pois a cultura passa a ser reconhecida como:

o lugar de inovação e expressão da criatividade brasileira que se apresenta como parte constitutiva do novo cenário de desenvolvimento econômico socialmente justo e sustentável [...] tornando-se imperativo a regulação das "economias da cultura", de modo a evitar os monopólios comerciais, a exclusão e os impactos destrutivos da exploração predatória do meio ambiente e dos valores simbólicos a ele relacionados.

Nesse contexto, reconhece-se hoje a existência de uma economia da cultura que, sendo melhor regulada e incentivada, pode ser vista como um vetor de desenvolvimento essencial para a inclusão social através da geração de ocupação e renda. Assim, nesta perspectiva, o Ministério da Cultura busca implementar e consolidar políticas norteadas pelo Plano Nacional de Cultura (PNC), aprovado pela Lei 12.342 de 03/12/2010 que prevê, entre suas estratégias, a ampliação da participação da cultura no desenvolvimento socioeconômico sustentável. Considerando a importância da cultura como vetor de desenvolvimento social e econômico do país, dentre as políticas da Secretaria da Economia Criativa (SEC/MinC) de apoio ao desenvolvimento territorial, destaca-se o fomento a Arranjos Produtivos Locais (APL's) Intensivos em Cultura.

Os APL's culturais detêm aglomerações territoriais de agentes econômicos, políticos e sociais, com o foco em um conjunto específico de atividades oriundas dos setores culturais e $\operatorname{criativos}^{13}$, que apresentam vínculos produtivos e institucionais, organizados por setores da economia criativa como: a) Arquitetura e urbanismo b) Artesanato c) Artes Visuais d) Arte Digital e) Artes de espetáculo: dança, música, circo, teatro f) Audiovisual, incluindo jogos eletrônicos g) Culturas Populares incluindo Culturas Indígenas e Culturas Afro-brasileiras h) Design i) Festas populares j) Gastronomia Regional k) Moda 1) Publicações e mídias impressas, leitura e literatura m) Turismo Cultural.

${ }^{13}$ Escopo dos Setores Criativos do Ministério da Cultura: No campo do Patrimônio - Setores: Patrimônio Material; Patrimônio Imaterial; Arquivos; Museus. No campo das expressões culturais - Setores: Artesanato; Culturas Populares; Culturas Indígenas; Culturas Afrobrasileiras; Artes Visuais; Arte Digital. No campo das Artes de Espetáculo - Setores: Dança, Música, Circo, Teatro. No campo do Audiovisual/do Livro, da leitura e da Literatura Setores: Cinema e Vídeo; Publicações e mídia impressas. No campo das Criações Culturais Funcionais - Setores: Moda, Design, Arquitetura. No Conselho Nacional de Política Cultural (CNPC) a Secretaria da Economia Criativa coordena os colegiados dos setores da moda, do artesanato, do design, da arquitetura e da gastronomia. 
Dentre aqueles que já foram catalogados pelo Ministério do Desenvolvimento, Indústria e Comércio Exterior, por meio da Secretaria do Desenvolvimento da Produção/SDP através de Editais, estão os APL's Culturais Populares incluindo Culturas Indígenas e Culturas Afro-brasileiras e Design (figura 5).

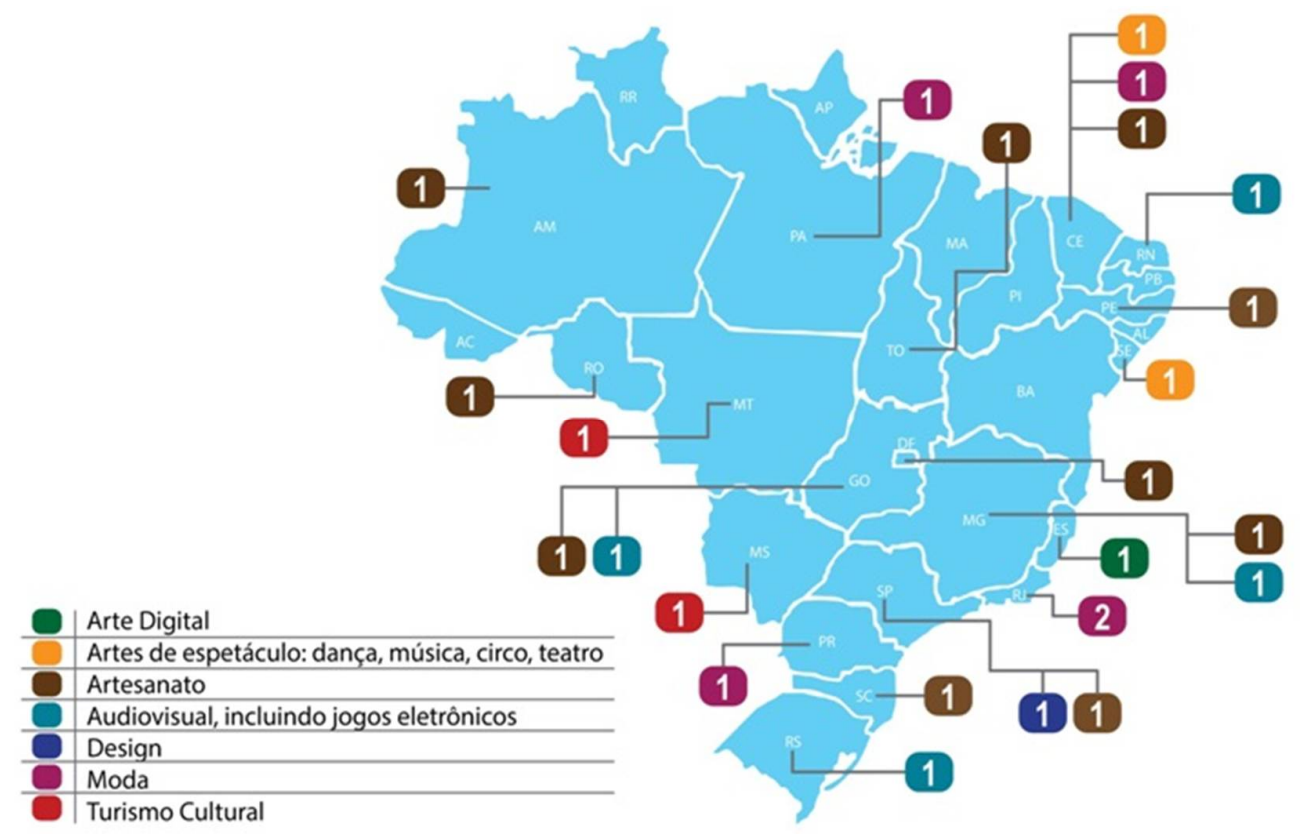

Figura 5 - Localização dos APL's de base cultural (Nicolau, 2015)

\section{3.}

Cooperação entre arranjos produtivos locais brasileiros

Wisner (1992) afirma que é necessário adequar a tecnologia ao ser humano levando em consideração o meio, a cultura, a geografia, os saberes, a singularidade de cada local e região. No artesanato, não há um modelo sistematizado e cientificamente testado de transferência de tecnologia/inovação que seja aplicável em todas as comunidades de produção artesanal respeitando suas particularidades. Suas habilidades advêm do refletir no aproveitamento das ofertas em recursos e demandas territoriais que permitiram estruturas de produção desenvolvida pelo próprio artesão ou ancestrais.

A inovação tecnológica pode apoiar a construção de uma infraestrutura produtiva artesanal, não alienante (sem divisão do trabalho ou trabalho escravo), respeitando as habilidades do artesão, contudo permitindo qualidade ao produto, capacidade produtiva, não impactos ambientais e qualidade de vida. Segundo 
Matos (2013, p. 9; 10), uma característica que distingue fortemente as atividades culturais de outros segmentos produtivos é o envolvimento dos agentes em relações cooperativas. Destaca-se uma propensão para a cooperação muito mais intensa nas atividades culturais do que em segmentos não culturais. Nascimento e Costa (2011) abordam a questão da cooperação pelo ponto de vista da dádiva ${ }^{14}$, porque permite compreender que a cooperação entre atores de grupos territoriais, de vivência próxima, não se reduz ao interesse econômico, mas como citam os autores possibilita ampliar o enfoque e registrar formas de cooperação que visam o bem comum, em relações de camaradagem, exprimindo o circuito da dádiva de dar, receber, retribuir.

Entretanto, não foi identificada, na literatura revisada, a existência de cooperação entre APL's de Artesanato e APL's de outros setores produtivos. Contudo, a experiência da economia solidária mostra que a necessidade de compra de insumos industriais para a produção dos artesanatos, faz com que haja cooperação entre fabricantes de insumos e empreendimentos: não se alcança $o$ preço justo, mas há grandes possibilidades de descontos (resposta concedida à pesquisadora, por empreendimentos solidários, durante uma das reuniões do Fórum de Economia solidária (2015), da cidade de Novo Hamburgo no Rio Grande do Sul).

\section{4.}

\section{A dimensão social do design sob uma visão estratégica de ação}

O design é um dos principais instrumentos de uma organização que tem o caráter inovador e a capacidade de reverter a inovação em resultados financeiros, pela habilidade de relacionar diversas atividades da organização empresarial ou de sua cadeia de valor, tornando-o um vetor estratégico (Franzato, 2011). Entretanto, Borja de Mozota (2003) ressalta que é preciso gerencia-lo à inovação para que não esteja somente vinculado ao nível operacional de desenvolvimento de produto, mas também ao planejamento estratégico da organização.

O desenvolvimento de produtos (DP) em nível estratégico é uma tentativa de articulação das necessidades de mercado, das possibilidades

14 Dádiva - A origem desse novo paradigma, apenas anunciado ou esboçado por alguns teóricos europeus, canadenses, australianos e latino-americanos, encontra-se no famoso texto Ensaio sobre a dádiva: forma e razão da troca nas sociedades antigas (1923), de Marcel Mauss, embora a reflexão sobre a dádiva exista há muito tempo (Nascimento \& Costa, 2011). 
tecnológicas e das competências da empresa (Cheng, 2000, p. 4). Os processos de inovação são realizados por grupos multidisciplinares, tendo como fonte inicial o planejamento estratégico do negócio - PEN, do qual derivam as estratégias de P\&D (Pesquisa e Desenvolvimento) e subsidiam as ações estratégicas do design (Clark e Wheelwright, 1993; Zurlo, 2010).

Contudo, Gavira et al (2007, p. 83) ressaltam que antes de iniciar a caracterização das ferramentas para o processo de inovação é interessante atentar para uma questão fundamental sobre as equipes de desenvolvimento como a definição sobre os projetos e o grau de inovação proposto em cada um deles. Assim sendo, tendo esta tese o propósito de desenvolver um sistema de projetação e produção distribuída de $\operatorname{produtos}^{15}$ para atenção básica, o planejamento estratégico deverá considerar a existência de diferentes estágios de vivencia desta situação para então alocar as equipes e identificar a definição dos projetos e grau de inovação. São considerados três estágios de atendimento: o momento de urgência (de atenção imediata), de manutenção (desenvolvimento continuo) e sustentável (situação ideal). Estes estágios devem ser reconhecidos como stage gates dependentes, como um processo contínuo de desenvolvimento tendo como meta uma condição sustentável de bem viver.

Nesse sentido, quanto as equipes de desenvolvimento, segunda a teoria das formas organizacionais cooperativas, a inovação para competitividade deve ser sustentável, significando que a organização deva possuir um diferencial, ou um atributo distinto de seus competidores, definido por uma habilidade estratégica de captar informações do ambiente externo e transformá-las em conhecimento, realizada de forma cooperativa pela sua cadeia de valores. Esta habilidade é propulsionada por duas alavancas: a arquitetura, entendida como a compreensão da empresa em relação ao seu papel como parte integrante de seu ambiente externo, e a reputação, definida pela composição de signos, símbolos e processos que determinam a identidade da empresa (Kay, 1993 apud Freire, 2014). Segundo Zurlo (2010) é:

${ }^{15}$ Tipo de produtos pretendidos pelo Sistema: bens de consumo duráveis e semi-duráveis, de média complexidade tecnológica para atender necessidades básicas de segurança, higiene, proteção da saúde, auxilio na vida diária. vestuário, educação e lazer. 
uma estratégia de diálogo e confronto, conversa e negociação entre múltiplos atores, que visa alcançar alguma forma de sucesso (um resultado que tem sentido para alguém).

Contudo, se esse comportamento de diálogo e confronto for entendido como um processo comportamental de acontecimento de co-pensamento, uma maneira de juntos encontrar um caminho à inovação, mesmo que tenha sentido para um "alguém", mas que também vai impactar no desejo do grupo que se reuniu por semelhanças em propósitos, podemos entendê-lo sob o sentido de cooperação que Albuquerque (2014) apresenta como o:

Processo que traduz um conjunto de ações cuja intencionalidade das relações estabelecidas é resolver um problema que não pode ser resolvido de forma individual; as relações que se estabelecem entre o tu/eu podem se caracterizar como relações verticais e de dominação ou horizontais e de emancipação.

Contudo, pensar processos de inovação social, que são naturalmente de autogestão, a partir do referencial cooperativo significaria reduzi-lo à (Albuquerque, 2014, p. 392):

"mitologia do bom selvagem", que dissimula a realidade social e a complexidade do processo de produção, induzindo a crença nostálgica de que uma relação simples e sana entre aqueles que produzem pode ser promovida através de sistema de participação propostos e de responsabilidade apenas gerencial.

Nesse sentido, sob a perspectiva do design social, e retomando a discussão sobre o processo de inovação por desenvolvimento tecnológico, referenciado no formato da THD (Etkowitz e Zuho, 2006), pode-se assumir que um processo de inovação tecnológica (produtos e processos) voltado a atender necessidades sociais, de atenção básica, pode ocorrer em uma estrutura em que os agentes formadores da THDS (empresa-universidade-governo-sociedade), quando em movimento de co-dialogo (Zurlo, 2010), co-design (Meroni, 2008) ou consenso autogestionário (Albuquerque, 2014, p. 393), impulsionados por um movimento elíptico com origem de força nas suas arquiteturas e reputações (Kay, 1993), que mesmo havendo uma intencionalidade individual, as relações que se estabelecem transformam o modo de pensar uno e se expandem ao bem comum de um coletivo (figura 6).

Uma proposição que permite assumir que o formato da Tríplice Hélice Dupla (THD) da sustentabilidade, pode ser envolto pelas relações das alavancas 
estratégicas na configuração de vantagens competitivas sustentáveis (Freire, 2014), como forma de desenvolver uma inovação voltada a atender necessidades sociais complexas de abrangências macro ou micro, independente da origem geográfica, abrangência e relação institucional dos atores em rede.

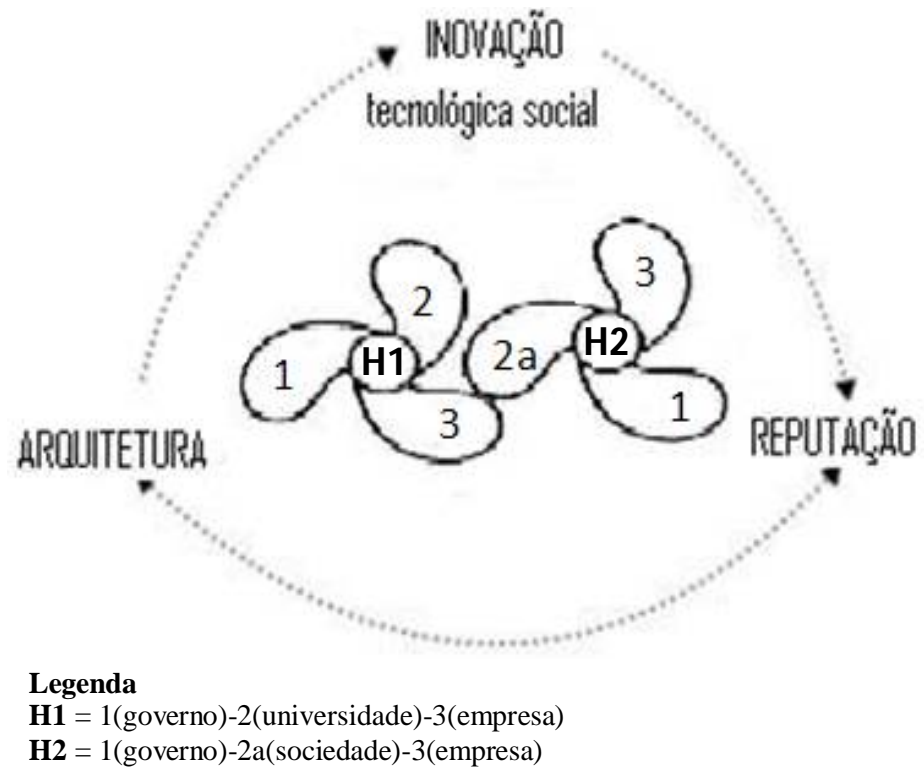

Figura 6 - Relações das alavancas estratégicas para impulsionar a inovação tecnológica social (a partir de Freire, 2014).

A figura 6 mostra uma situação ideal onde a inovação tecnológica social é consenso, portanto o resultado das alavancas e do comportamento dos atores em rede. Contudo há que considerar que se a inovação estiver no centro da atenção (figura 7), provocando as relações ao seu entorno, talvez o grau de tensão (fatores políticos, ausência de conscientização, de relações não convergentes e econômicas) seja forte o suficiente para romper ou não constituírem laços (omissão) entre todos os atores de uma THD da sustentabilidade. Na realidade, é o que ocorre nos modelos entre comunidade-universidade, de ação extensionista ou universidade-empresa, de projetos em parceria para inovação tecnológica. 


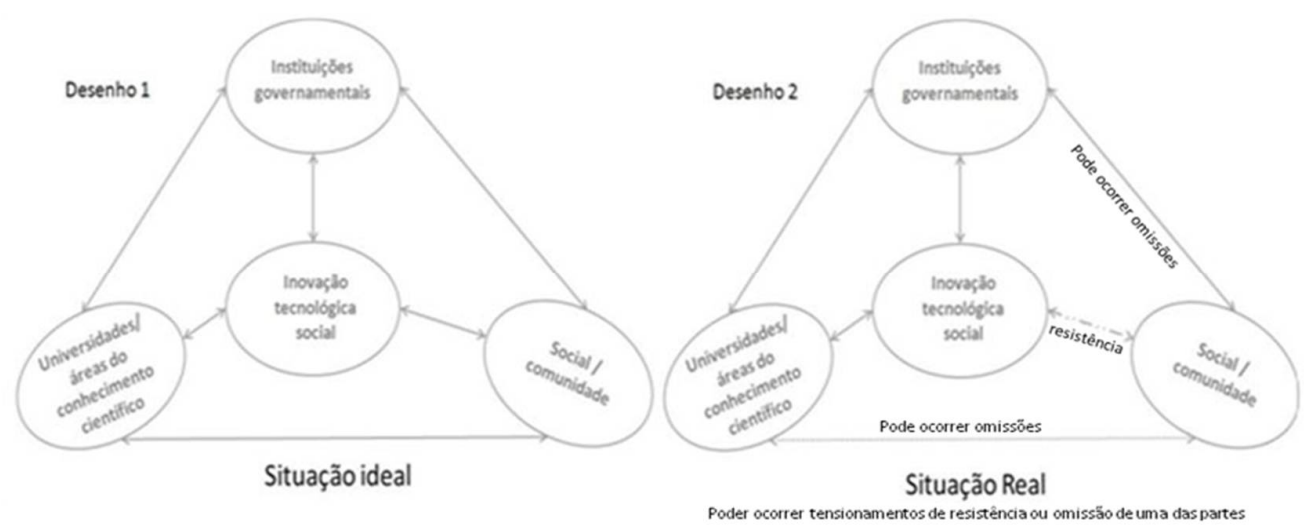

Figura 7 - THDS com a inovação tecnológica social no centro das atenções em situação ideal (desenho 1) e em situação real (desenho 2).

Assumindo o desejo de transformação ou contribuição à situação real, o design tem capacidade de desempenhar um papel estratégico de elo formador das relações entre os atores (governo-empresa-universidade-sociedade) que poderão constituir o modelo ideal para a inovação tecnológica social.

\section{5 . Design social e inovações tecnológicas de atenção básica}

Darcy Ribeiro, ao se referir às discussões sobre design e responsabilidade social, no prefácio do livro A Tecnologia da Tecnologia (Bonsiepe, 1983; 2012), discorre sobre a "permissão" da dominação tecnológica que nos ofereceu estilos de vida e de produção atípicos aos nossos costumes brasileiros. Disse o autor que:

tal permissão foi responsável pela "perda de nossa propriedade criativa", porque seus métodos, constituídos com a promessa de progresso, excluíam a autonomia. Ele argumenta que enquanto nosso projeto de vida permanecer descomprometido com o nosso povo, estaremos submissos à "permissão". Só realizamos nossas próprias potencialidades projetando, nós mesmos, o futuro que queremos para nós. Isso só sucederá quando desenvolvermos estilos de vida e modos de consumo que não se regem pelo primado de lucro, mas que queiram fundamentalmente atender às necessidades de nossa população, em termos de emprego, comida, educação, saúde e moradia (Ribeiro apud Bonsiepe, 1983; 2012).

Todo design é destinado à sociedade (Redig, 2011, p. 93), entretanto as atuais abordagens do design comprometido com questões sociais têm garantido denominações diversas, mas a denominação mais divulgada é: "design social", a mesma utilizada na primeira dissertação de mestrado no Brasil sob a temática, apresentada, em 1996, na PUC-RIO, por Helena Soneghet Pacheco (Pacheco, 1996) sob a orientação do Professor Henrique Antoun. A diferença entre o design tradicional e o social está na demanda da encomenda, pois o social visa atender 
necessidades de populações que não constituem uma classe de consumidores com poder de compra (Margolin e Margolin, 2006).

\subsection{1.}

\section{Experiências do design social no Brasil}

As experiências projetuais do design social no Brasil foram identificadas considerando a investigação de projetos brasileiros, que ocorreu em 3 momentos: 1) definição de critérios para investigação: projetos em design voltados a atender necessidades de populações de baixa renda desenvolvidos por grupos de pesquisa do campo do design; 2) levantamento de dados: a) por palavras-chaves nas bases de dados científicas e, b) junto aos Cursos de Graduação e Pós Graduação; 3) organização e análise dos dados: para operacionalizar a investigação dos projetos foram definidos 33 critérios, organizados em 5 grupos, seguindo uma estrutura por modelo de Gestão do processo de desenvolvimento de produto (Rozenfeld et al, 2006; Ulrich e Eppinger (2000); Clark e Wheelwright, 1993). Os grupos definidos foram: Grupo 1 - Dados identificadores / demográficos do projeto; Grupo 2 -Dados do Planejamento estratégico do projeto; Grupo 3 - Dados metodológicos do projeto, Grupo 4 - Dados sobre o desenvolvimento do produto; e Grupo 5 - Pós-desenvolvimento e resultados do Projeto. O Apêndice I apresenta a lista de critérios organizados pelo grupo a que pertencem, bem como a descrição qualitativa de cada um dos critérios.

O primeiro momento de investigação foi de identificação dos grupos de pesquisa e coleta organizada de informação realizada junto às bases de dados, disponibilizadas pelo sistema de bibliotecas da PUC Rio e as de livre acesso pelos sites de busca Google (para assuntos gerais) e Google Scholar (para assuntos acadêmicos). As buscas foram guiadas pelas palavras-chaves: design social, design e comunidades de baixa renda, design e empoderamento, design e serviço social, design e pobreza, design e políticas públicas. As palavras-chaves foram identificadas nos referenciais teóricos, previamente, consultados.

Foram identificados 7 projetos, desenvolvidos por grupos de design vinculados as Universidades, com resultados apresentados em artigos científicos (figura 8). Dentre eles, 1 projeto de pesquisa-ação, desenvolvido em um trabalho de conclusão, não foi apresentado em artigo cientifico, portanto a fonte foi o site do projeto. 


\begin{tabular}{|c|c|c|}
\hline Projeto & Foco e objetivo & Produto desenvolvido \\
\hline 1 & $\begin{array}{l}\text { Artesanato, focado na qualidade de } \\
\text { produção do objeto. Aproveitamento de } \\
\text { resíduos; geração de renda e trabalho }\end{array}$ & $\begin{array}{l}\text { Pen drive, sacolas e } \\
\text { lixeirinhas }\end{array}$ \\
\hline 2 & $\begin{array}{l}\text { Artesanato. Aproveitamento de resíduos } \\
\text { de outro setor produtivo (têxtil); geração } \\
\text { de renda e trabalho para mulheres mães. }\end{array}$ & $\begin{array}{l}\text { Chaveirinhos temáticos em } \\
\text { tecido; saches; móbiles; } \\
\text { sacolas e almofadas. }\end{array}$ \\
\hline 3 & $\begin{array}{l}\text { Artesanato. Busca a geração de renda } \\
\text { através da venda de produtos artesanais } \\
\text { feitos com materiais reutilizados como } \\
\text { banners, retalhos de tecidos, garrafas pet, } \\
\text { etc. Mescla design e empreendedorismo } \\
\text { popular }\end{array}$ & $\begin{array}{l}\text { Sacolas, porta trecos, e } \\
\text { capas para agendas e } \\
\text { cadernos. }\end{array}$ \\
\hline 4 & $\begin{array}{l}\text { Artesanato. Uniu antigos conhecimentos } \\
\text { a modernas técnicas de design. O } \\
\text { resultado é a criação de uma coleção } \\
\text { original e autêntica, produzida em } \\
\text { parceria com comunidades que guardam } \\
\text { séculos de conhecimento. }\end{array}$ & $\begin{array}{l}\text { Bijuterias: colares de frutas, } \\
\text { chaveiros e fruteiras. Objetos } \\
\text { de decoração: peças } \\
\text { artesanais em madeira e } \\
\text { fibras, cestos, tabuleiros, } \\
\text { máscaras e tapetes em } \\
\text { palha de carnaúba (uso e } \\
\text { decoração). }\end{array}$ \\
\hline 5 & $\begin{array}{l}\text { Atender comunidades de baixa renda, } \\
\text { que têm no artesanato sua forma básica } \\
\text { de subsistência, preocupando-se com a } \\
\text { qualificação do produto artesanal e sua } \\
\text { inserção no mercado. }\end{array}$ & $\begin{array}{l}\text { Cadernos de anotações com } \\
\text { papeis artesanais, fantasias } \\
\text { e apliques para decoração } \\
\text { de roupas (flores em tecido). }\end{array}$ \\
\hline 6 & $\begin{array}{l}\text { intervenção do design em comunidade da } \\
\text { periferia da cidade de São Luís e sua } \\
\text { produção artesanal. bordam-se questões } \\
\text { relativas à economia solidária, } \\
\text { sustentabilidade, artesanato e trabalhos } \\
\text { manuais, design e moda }\end{array}$ & Bolsas femininas \\
\hline 7 & $\begin{array}{l}\text { princípios do design permacultura para } \\
\text { regeneração ambiental do território } \\
\text { habitado. técnicas de bioconstrução para } \\
\text { construção ou melhoria das habitações } \\
\text { com menor impacto ambiental. }\end{array}$ & $\begin{array}{l}\text { Banheiros compostáveis e } \\
\text { lavanderias com tratamento } \\
\text { ecológico das águas } \\
\text { residuais }\end{array}$ \\
\hline
\end{tabular}

Figura 8 - Objetivos e produtos desenvolvidos por projetos brasileiros

Os projetos têm o formato de rede de atores: universidade - comunidade como modalidade de projeto de ensino-pesquisa-extensão. Dentre os projetos 1 apresentou proposta para atendimento à necessidade básica: técnicas de bioconstrução para melhoria das habitações com menor impacto ambiental. Os demais projetos utilizaram métodos participativos com artesãos, propondo intervenções no artesanato, para adequação dos objetos ao mercado consumidor. Todos os projetos analisados são de produção artesanal, sem inserção de meios industriais. Nenhum dos produtos identificados eram produzidos para uso local, com venda de seus excedentes, sendo destinados para consumidores de fora da comunidade (comercialização). 


\subsection{2. \\ Investigação dos projetos brasileiros junto aos cursos de graduação e pós-graduação do Brasil}

Para coleta e análise dos dados, foi utilizada a ferramenta Design Macroergonômico (DM) proposta por Fogliatto e Guimarães (1999). Basicamente, o DM é uma ferramenta de apoio ao design, baseada nos preceitos da macroergonomia, visando as questões que importam na melhoria de produtos, processos e postos de trabalho.

O DM, quanto à sua abordagem, é classificada como uma técnica qualiquantitativa, possuindo análise estatística e análise de dados não numéricos, como entrevistas e depoimentos. Seu principal diferencial para as demais ferramentas é sua estratégia de estimular e considerar a manifestação da opinião dos usuários quanto as suas demandas. Nesse sentido, o seu instrumento principal é a entrevista com perguntas abertas e questionário..

A aplicação do DM contempla sete fases, contudo foram usadas apenas as duas primeiras para as análises dos dados, pois é um momento de investigação do método deste Capítulo. As fases utilizadas foram: Fase 1 - identificação do usuário e coleta organizada de informação e Fase 2 - priorização dos itens de demanda ergonômica (IDEs) identificados pelas citações do usuário, com o objetivo de criar um ranking de itens demandados (FOGLIATTO e GUIMARÃES, 1999). Na Fase 2 e utilizada uma planilha EXCELL para gerar um ranking dos itens citados pelos entrevistados. Por exemplo, os primeiros três itens de demanda mencionados no módulo espontâneo da entrevista recebem pesos de importância pela ordem de menção de cada fator. O peso de importância de um fator mencionado na p/ésima posição, é dado pelo recíproco da respectiva posição; ou seja, 1 /p (resultando nos pesos 1,0, 0,5, 0,33, e assim por diante, garantindo um alto peso de importância para os primeiros fatores mencionados.

Alternativamente, pode-se atribuir pesos de importância 3,0, 2,0 e 1,0, em ordem decrescente de importância; os demais itens do módulo espontâneo, bem como todos os itens de módulo induzido recebem peso 1,0.

Uma vez pontuados em todas as entrevistas, os IDE's têm seus pesos somados; a partir dos pesos finais pode-se gerar um ranking de importância para esses itens. Tal ranking utiliza a suposição de que a ordem de menção dos IDEs 
tende a refletir a postura do entrevistado quanto à sua importância onde os três primeiros fatores mencionados tendem a ser os mais importantes.

Em segundo momento, foram contatados os programas de cursos de graduação e pós-graduação em Design do Brasil. A fonte utilizada para busca dos cursos de pós-graduação foi a lista de cursos cadastrados e indicados pela Coordenação de Aperfeiçoamento de Pessoal de Nível Superior (CAPES). Já a fonte para acesso aos cursos de graduação em Design no Brasil foi o sistema eMec, do Ministério da Educação.

Para a coleta das informações junto aos cursos de graduação e de pósgraduação em Design, foi desenvolvido um questionário, sob o título: Design e ações para populações de baixa renda, contendo as seguintes perguntas: (1) Nome do grupo e Universidade, (2) Se curso: Graduação ou Pós- graduação, (3) O grupo desenvolveu algum projeto (ensino, pesquisa ou extensão) com o objetivo de atender demandas de populações de baixa renda? Se, sim, qual a demanda atendida, (4) O projeto foi implementado? (5) Quais os objetivos do projeto? e (6) Envolveu o desenvolvimento de um produto ou serviço?

Quanto aos cursos de pós-graduação, foram enviados 19 emails, conforme o número de contatos disponibilizados pela lista da CAPES. No entanto, os contatos que estavam naquela lista não eram dos Coordenadores de Curso e, sim, de pessoas que poderiam responder, institucionalmente, pelo Curso a CAPES.

Nesse sentido, para garantir a chegada do questionário junto aos cursos, a lista foi refeita, acessando-se o site de cada curso, sendo que algumas vezes foi preciso telefonar para descobrir o nome e o email do Coordenador de Curso. O trabalho resultou em nova lista, a qual guiou o segundo envio de questionários, para 17 emails.

Em relação aos cursos de graduação, o sistema e-MEC disponibiliza uma busca específica em função dos interesses do usuário. Nesse sentido, foi feita uma busca por cursos de design de produto. A lista recebida continha 48 cursos, mas algumas instituições apareciam duplicadas, porque o número de cursos está vinculado a critérios como: grau do curso, se bacharelado ou tecnológico, e ainda quanto à modalidade do curso: se presencial ou à distância. Assim, uma nova lista foi organizada sem duplicidade de menção das instituições, o que resultou em 41 cursos de design de produto no Brasil listados no sistema e-MEC e 41 emails enviados. 
Em resumo, foram enviados 17 emails aos coordenadores dos cursos de pósgraduação, além dos 19 emails enviados da primeira lista, perfazendo um total de 36 emails de contato aos cursos de pós-graduação em design no Brasil. Quanto aos cursos de graduação em design, foram enviados 41 emails de contato. Ao todo, foram enviados 77 emails com o questionário. Após um período de 3 meses para recebimento de respostas, houve retorno de 11 questionários, ou seja, de 14 $\%$ dos cursos contatados.

Quanto à primeira pergunta, a fim de não expor o grupo respondente, e até porque não foi pedido autorização, serão apenas citadas as regiões das Universidades: Santa Catarina, Campina Grande, Rio Grande do Sul (Porto Alegre e São Leopoldo), Pernambuco e Belo Horizonte.

Quanto à segunda pergunta: Se curso: Graduação ou Pós-graduação? Os resultados mostram que dentre os 11 respondentes, $60 \%$ foram de cursos de pósgraduação e $40 \%$ do curso de graduação.

Quanto à terceira pergunta: $\mathrm{O}$ grupo desenvolveu algum projeto (ensino, pesquisa ou extensão) com o objetivo de atender demandas de populações de baixa renda? A lista dos itens citados é apresentada na figura 9. Dos 10 respondentes, $8(83 \%)$, sendo 4 grupos de pós-graduação e 4 de graduação, afirmaram que "desenvolveram algum projeto". Dois grupos entre os 10 (17\%) opinaram que "não possuem projetos que atendam a esta demanda". 


\begin{tabular}{|c|c|c|}
\hline $\begin{array}{l}\mathrm{N}^{\circ} \text {. de } \\
\text { respon } \\
\text { dentes }\end{array}$ & ITENS DE DEMANDA CITADOS PELOS RESPONDENTES & $\%$ \\
\hline 1 & Infelizmente não tenho projetos com essas demandas. & \multirow{2}{*}{17} \\
\hline 2 & Não & \\
\hline 3 & $\begin{array}{l}\text { Projeto de pesquisa e extensão em design desenvolvido com o } \\
\text { objetivo de proporcionar aos agricultores e produtores familiares do } \\
\text { semiárido sistema de embalagem e de identificação de produtos. }\end{array}$ & \multirow{8}{*}{83} \\
\hline 4 & $\begin{array}{l}\text { Sim. Temos um projeto destinado à elaboração de dispositivo } \\
\text { digital para reabilitação de pacientes acometidos por AVC (a } \\
\text { pesquisa foi desenvolvida com pacientes do Hospital Universitário) // } \\
\text { Temos, também, outro projeto (Jogo Digital) destinado ao } \\
\text { esclarecimento de pré-adolescentes (estudantes de escola pública } \\
\text { no Rio Grande do Norte) a respeito da identificação de sintomas de } \\
\text { AVC e da divulgação dos procedimentos necessários para } \\
\text { acionamento da SAMU. }\end{array}$ & \\
\hline 5 & $\begin{array}{l}\text { Sim. Projeto Bancos Sociais (Extensão) // Cada Banco busca } \\
\text { identificar a demanda da população carente com o setor } \\
\text { Empresarial que produz o excedente, tais como necessidade de } \\
\text { móveis e Indústria do Mobiliário (Banco de Mobiliários), carência } \\
\text { de roupas, Indústria Têxtil e de Vestuários (Banco de Vestuários), e } \\
\text { assim com os demais Bancos (FGBS, 2013). Os Bancos de } \\
\text { Mobiliários e de Vestuários recebem excedentes } \\
\text { diversificados e, a partir disso, produzem novos produtos e os } \\
\text { distribui de acordo com demandas de instituições assistenciais, }\end{array}$ & \\
\hline 6 & $\begin{array}{l}\text { Sim. O curso de Design tem graduação e pós-graduação. } \\
\text { Participam do Laboratório professores que atuam na graduação e na } \\
\text { pós- graduação. }\end{array}$ & \\
\hline 7 & $\begin{array}{l}\text { Sim. Atualmente desenvolve um projeto na área de Design } \\
\text { Estratégico para Economia Solidária. }\end{array}$ & \\
\hline 8 & Sim, extensão em Design de Resíduos. & \\
\hline 9 & $\begin{array}{l}\text { Sim. Junto à Vila Gaúcha - Indicadores de saúde coletiva- periferia } \\
\text { de Porto Alegre, RS. E junto a Comunidades quilombolas de Viamão, }\end{array}$ & \\
\hline 10 & $\begin{array}{l}\text { Sim. a Régua da inclusão é um instrumento multifuncional que } \\
\text { surgiu através de um projeto de ensino, pesquisa e extensão do } \\
\text { Centro Universitário Tupy - UNISOCIESC. }\end{array}$ & \\
\hline
\end{tabular}

Figura 9 - Itens de demanda citados pelos respondentes

A quarta pergunta: $O$ projeto foi implementado? teve 11 respondentes: 5 projetos implementados - sendo 3 de graduação e 2 de pós-graduação; 6 projetos em implementação - sendo 2 de graduação e 4 de pós-graduação e 2 grupos responderam que não tem projetos. Alguns grupos possuem mais que um projeto desenvolvido.

Quanto ao produto desenvolvido pelo projeto: o $1^{\mathrm{o}}$ projeto: estava propondo ampliação de uma renda extra; o $2^{\circ}$. projeto: objetivou melhorias no serviço de saúde, o $3^{\circ}$. projeto : o projeto atendia às necessidades de produtores familiares através do desenvolvimento de embalagens e sistemas de identidade visual para produtos alimentícios desenvolvidos na região semiárida da Paraíba; o 4 projeto: tinha como objetivo projetar uma tecnologia assistiva para cegos. visando 
melhorar as atividades escolares e do dia a dia dessa população que carece de materiais adaptados. O produto desenvolvido foi a Régua da Inclusão, que foi distribuído gratuitamente, em escala piloto, fabricada nos laboratórios da Universidade; e o $5^{\circ}$. Projeto: objetivou intervenções de design para tornar sustentável o artesanato desenvolvido por comunidades produtoras do Estado de Pernambuco. Não foram identificados produtos para satisfazer necessidades básicas, o foco são objetos de decoração, utensílios de cozinha e brinquedos.

\subsection{3.}

\section{Análise dos projetos dos grupos brasileiros}

Os formatos de rede de atores foram do tipo universidade-comunidade, uma modalidade de projeto de pesquisa-ensino-extensão. Não foram identificados projetos nos formatos para desenvolvimento de inovação tecnológica do tipo

Tripla Hélice Dupla (universidade-empresa-governo, governo-sociedadeuniversidade). Os métodos de desenvolvimento das atividades tinham cunho participativo.,.

Não foram identificados projetos que estivessem vinculados a rede de aglomerados produtivos locais (APL’s), mas foram citados o uso de recursos locais (matéria-prima) e mão de obra artesanal, sem a inclusão de processos industriais (trabalho artesanal). Dentre os 18 projetos brasileiros (7 apresentados por artigos científicos e 11 por cursos de graduação e pós-graduação) 3 citaram a dificuldade na formação do grupo social local para dar início às atividades, ressaltando a importância de uma pessoa local (agente local) que tenha o papel de motivar e fazer a interveniência entre os pesquisadores e a comunidade.

Os projetos geraram produtos de comercialização para usuários de fora da comunidade. Dentre os 18 projetos, 3 atentaram para a atenção básica: a Régua da inclusão, o dispositivo para reabilitação de pacientes acometidos por AVC e os banheiros compostáveis, mas não foram implementados. No caso da Régua faltou um dos atores da rede da inovação: a empresa. Para o dispositivo e os banheiros faltou a finalização do desenvolvimento projetual, contemplando o planejamento estratégico operacional. 


\section{6.}

\section{Experiências internacionais do design social}

Quanto as abordagens internacionais do design social, há aquelas voltadas à transformação social pela conscientização do potencial inovador dos cidadãos, como é o caso do método de ação do evento itinerante e de diversidade participativa, coordenado pela Prof ${ }^{\mathrm{a}}$. Amy Smith, do Massachussets Institute of Technology - MIT, denominado IDDS - International Development Design Summitt, com sua primeira edição realizada em 2007. Outras já se propõe a investir em negócios com e para populações da base da pirâmide (BOP - bottom of pyramid population), como é o caso do grupo de pesquisadores da Delft University of Technology, com o projeto Designing with emerging markets design of products and services (2011).

O modelo de prática é tido como coparticipativo, pois o padrão organizacional dos projetos envolve uma comunidade de baixa renda, a universidade representada por um grupo de alunos (de graduação e pósgraduação) e uma empresa parceira.

Há também aquelas que se relacionam com a vertente de empodeiramento de comunidades, como é o caso do Grupo D-Impact, formado por professores da Universidade Cinccinati, nos Estados Unidos, sob a coordenação de Jamsey Ford (Hanisian e Ford, 2008). A proposta se baseia nos métodos de trabalho de assistentes sociais, tal como orienta Margolin e Margolin (2002, p. 25). Operacionalmente, suas práticas consideram como atores: indivíduos da comunidade, chamados por facilitadores e disseminadores de suas propostas no local.

Já os Designers Sem Fronteiras (DSF) (Designers Without Borders) (Kiganda et al, 2001) são formados por um consórcio de designers e educadores que trabalham para atender necessidades de comunicação de populações vivendo em regiões distantes de centros urbanos. Seus agentes são voluntários e são eles que disseminam o conhecimento da tecnologia, tanto para comunidades como para escolas. 


\subsection{1. Experiências internacionais do design social: Delft University of Technology}

Para a busca de projetos internacionais, também foram consultadas as bases de dados internacionais oferecidas pelo Sistema de Bibliotecas da PUC-Rio e as de livre acesso na internet, sob as palavras-chaves: social design, social technology and design, design for needs, design for changes, design for BOP POPULATION, design for emerging markets, design and poverty, design and poverty relieve, design for development e design and community empowerment. As palavras-chave e termos foram os que apareciam nos referenciais teóricos.

A definição do grupo a ser investigado deu-se pelo grau de saturação, ou o número de vezes que os grupos de pesquisa foram citados nas publicações científicas acessadas e consultadas. Desta forma, o grupo classificado para análise foi o da Design and Engineering for sustainability group da Delft University of Technology (TU DELFT), junto ao qual a pesquisadora realizou o seu período de doutorado sanduiche.

O grupo de design and engineering for sustainability, da TU Delft, desde 2009, discute o estado da arte dos impactos que possuem os negócios direcionados às populações da base da pirâmide - BOP Population (Prahalad, 2002). Objetivamente, buscam compreender como definir, planejar, medir e otimizar a criação e a durabilidade de BOP ventures, com a intenção de alcançar a expertise sobre os impactos de sustentabilidade nas circunstâncias econômicas, de capacidade, ambientais e bem-estar deste grupo de pessoas.

O trabalho está focado na rotina de ensino, pesquisa e extensão da Universidade. Os primeiros resultados foram publicados, em dois livros, compêndios, de projetos desenvolvidos por alunos, do curso de mestrado e doutorado em desenho industrial e engenharia, denominados: Designing for Emerging Markets - Design of Products and Services (Kandachar et al., 2009) e Designing with Emerging Markets: Design of Products and Services (Kandachar et al, 2011), conforme figura 10, respectivamente, a) e b). 


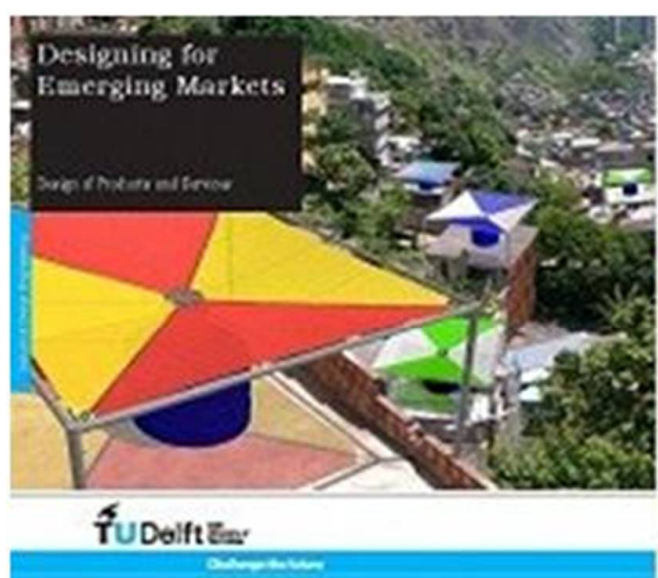

a)

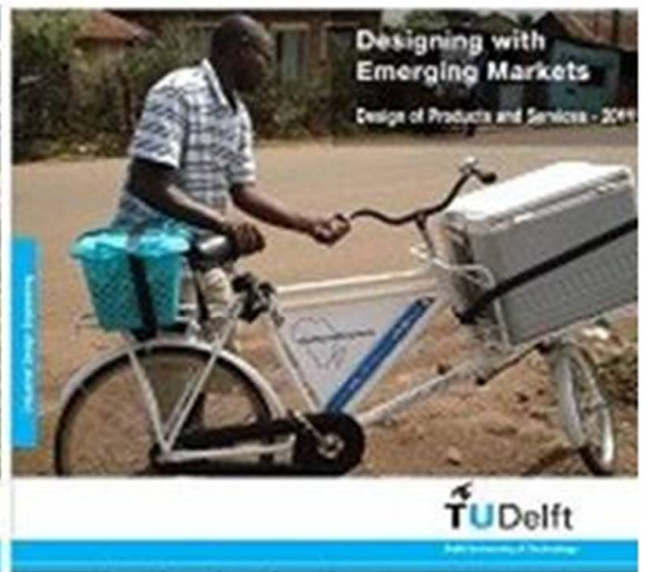

b)

Figura 10 - Capa dos Livros Designing for Emerging Markets - Design of Products and Services (Kandachar et al., 2009) e Designing with Emerging Markets: Design of Products and Services (Kandachar et al., 2011)

Além das publicações, a Delft University disponibilizou os relatórios apresentados por cada aluno sobre seus Projetos (armazenados na TU DELFT Repository com acesso local).

Para a primeira triagem, respeitou-se o critério: houve desenvolvimento de produtos? Foram avaliados, individualmente, os 40 e os 64 projetos publicados, respectivamente, no $1^{\circ}$. e $2^{\circ}$. Livro. Dos 104 projetos avaliados foram selecionados 18 projetos que apresentaram desenvolver produto até seu teste de campo ou distribuição no mercado.

Quanto ao critério "se implementados ou não", quando necessário, foram contatadas as empresas parceiras, como a Phillips para atualizar informações de permanência no portfólio da Empresa e no mercado quanto aos projetos: Repelamp, Insect Repepllent Lamp for the India Market, Redesign of a Smoke Free Batana Extractor and Cooking in Rural China.

Os projetos selecionados foram organizados, por grupos, relacionados às necessidades básicas atendidas por cada um deles, sendo: Grupo 1 - Água, Grupo 2 - Saúde e Alimentação, Grupo 3 - Energia, Grupo 4 - Mobilidade e empreendedorismo e Grupo 5 - Equipamentos que propõem melhorias em processos de produção relacionados à cultura local. O Apêndice I apresenta a lista de critérios organizados pelo grupo a que pertencem, bem como a descrição qualitativa de cada um dos critérios. 
As ações projetuais podem ser localizadas, no mapa mundi, por regiões atendidas pelo grupo da TU Delft, conforme figura 11.

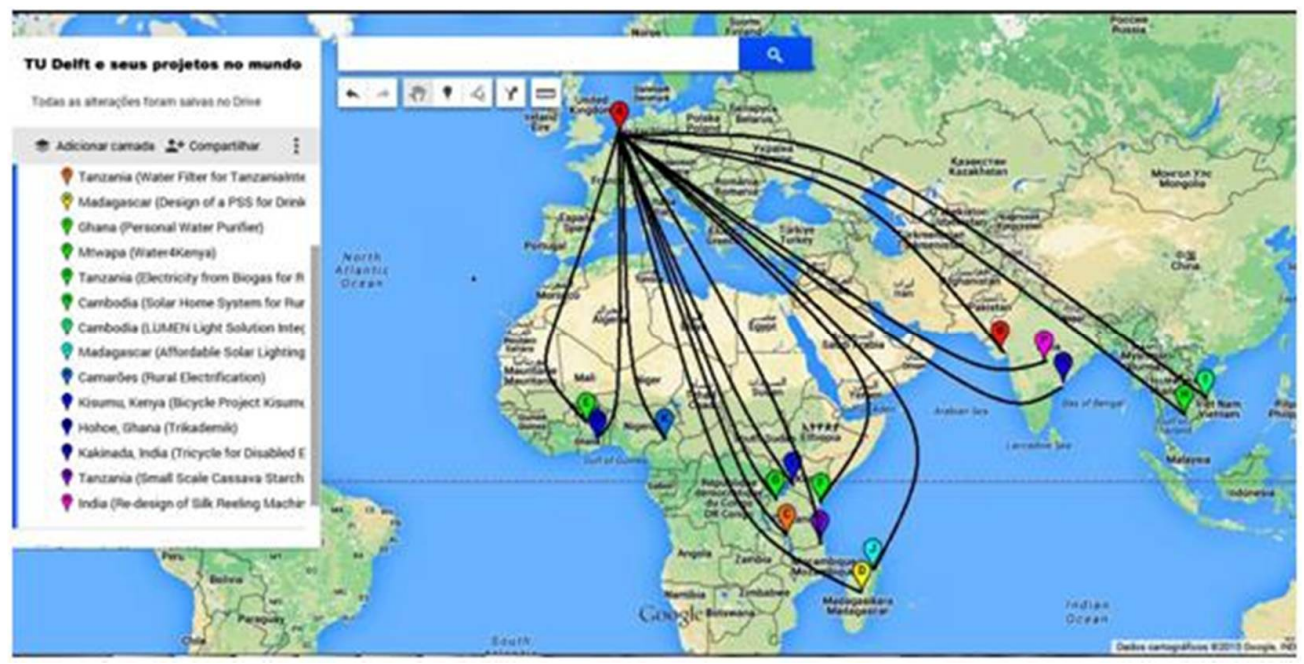

Figura 11 - Regiões atendidas pelos projetos do grupo de design and engineering,

da TU Delft, em relação a sua localização

\subsection{2.}

\section{Análises dos projetos da Delft University of Technology (TU DELFT)}

Os resultados dos projetos analisados da TU DELFT foram descritos em uma tabela que contém: na $1^{\mathrm{a}}$ coluna, a lista de critérios de análises; na $2^{\mathrm{a}}$ coluna a descrição de cada critério, e na terceira coluna a conclusão, por critério, dos 18 projetos definidos.

Além das análises, específicas de cada projeto, os pesquisadores do grupo de Delft fizeram questão de informar sobre a dificuldade de transformar invenção em inovação, que Tempelman (et al, 2012) denominam de Technology Transformation (TT). Como case apresentaram a Empresa D-Light que a implementação de seu negócio teve como maior desafio a estruturação da logística da cadeia de suprimentos para a fabricação de alguns produtos, especialmente aqueles que são distribuídos em regiões de difícil acesso, como na Ásia (Figura 12). A conclusão dos pesquisadores é de que a linha de produção deveria ser local porque a gestão desses vários pontos de fabricação e venda é de elevado custo para a empresa. Contudo, fica inviabilizada a proposta porque o desenvolvimento da inovação tecnológica não é local, como também não são as demandas e as ofertas locais (recursos para o sistema de produção) (Tice, 2013). 

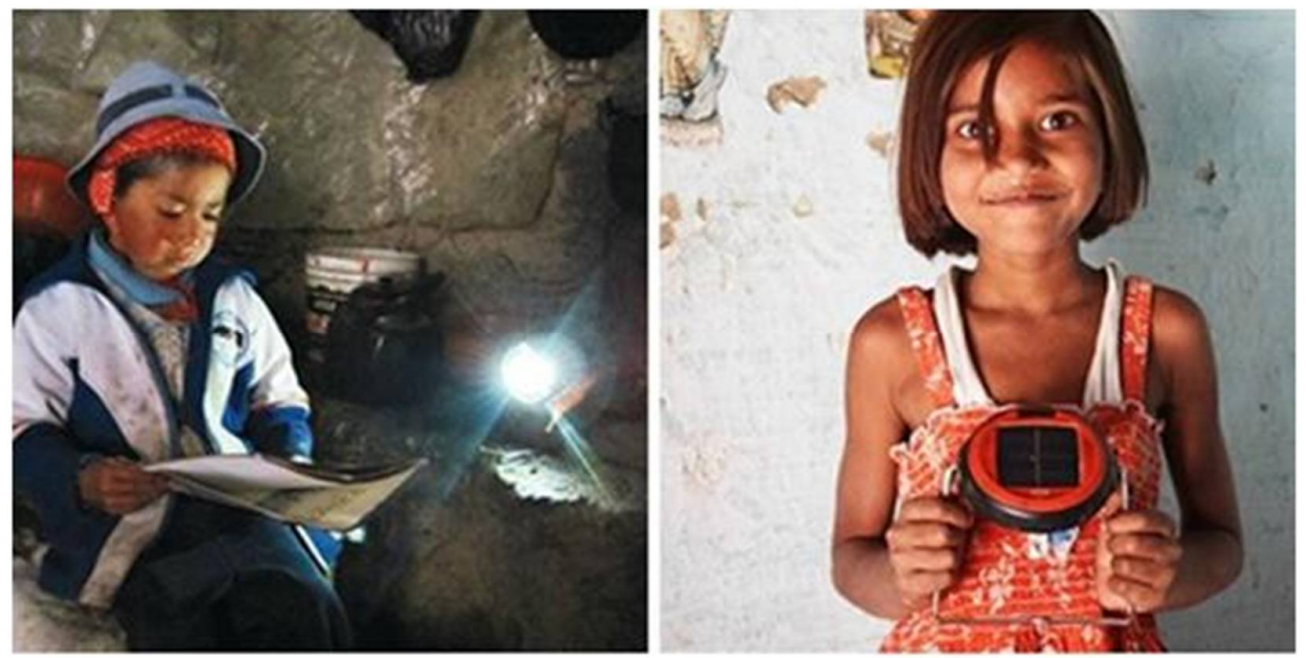

Figura 12 - Lâmpada carregada a energia solar fabricada pela Empresa D-Light (D.light S2: The Learning Light) (Tice, 2013)

\subsection{3.}

\section{Tecnologia social de atenção básica}

A palavra "social" tem conotação de atendimento a problemas sociais como a ausência de moradia, alimentação, educação, saúde, lazer, vestuário e higiene (Lei 8.742, de 07 de dezembro de 1993). Contudo, para atender a demanda da realidade brasileira (manter os 63,3\% de brasileiros, entre 2002 e 2012, que saíram da linha da pobreza extrema por medidas governamentais (IPEA, 2013), em processo de desenvolvimento social e humano), não basta modelos tecnológicos adequados a cada contexto ou situação, mas compreender, também, a estrutura de conhecimento e suas habilidades sociotécnicas capazes de fazer a ponte entre o conhecimento científico e o tácito ou saber popular, para um processo de desenvolvimento tecnológico social e participativo.

A adequação sociotécnica das tecnologias sociais é a transformação da visão sistemática e normativa de uma tecnologia estabelecida por teorias, experimentos e métodos do conhecimento científico, para a ideia de uma tecnologia, não neutra, determinada a atender problemáticas sociais de atenção básica, dentro da proposta de inovação sob o formato da tríplice hélice dupla (Erkowitz e Zhou, 2006).

No Brasil, no período de 1983 a 1985, ocorreu o Projeto Juramento - Prática de Implantação e Disseminação de Tecnologia Apropriada ao Meio Rural, firmado por contrato de cooperação técnica e financeira, entre a Fundação Centro Tecnológico de Minas Gerais - CETEC e a FINEP (1985), na cidade de Belo 
Horizonte/MG. Segundo Moraes (2008:82), durante a execução de um dos projetos, o de abastecimento de água, apesar da habilidade dos técnicos, barreiras foram encontradas com o uso do bambu como alternativa aos canos de PVC. O autor explica que mesmo o bambu sendo reconhecido como um material natural de propriedades uniformes, indeformável e que proporciona uma tubulação regular, as varas possuem variabilidade entre elas, especialmente no diâmetro, o que dificultou os encaixes. Desta forma o custo final de execução do projeto se tornou mais oneroso que o método industrial convencional, muito acima do esperado, apesar das técnicas de baixo custo definidas para a implantação do projeto. Os canos de $\mathrm{PVC}$, comparados às varas de bambu, eram de fácil acesso, baixo custo, além de oferecerem modularidade funcional e prática à execução.

Já em um contexto mundial, na década de 70, Victor Papanek, no lançamento de seu Livro Design for Real World, chama a atenção do campo do design para a responsabilidade social e ambiental, apresentando propostas e experimentos alternativos, construídos sob os conceitos, éticos e técnicos, semelhantes aos princípios da tecnologia social.

\section{7. Conceito de tecnologia social (TS)}

As tecnologias Sociais (TS) têm como característica aliar o saber popular, a organização social (o capital social) e o conhecimento técnico-científico para, em parceria e cooperação, solucionar demandas sociais quanto a carência de recursos para alimentação, hídricos, educação, energia, habitação, renda, saúde e preservação do meio ambiente. Estas soluções podem compreender produtos, técnicas ou metodologias, necessariamente reaplicáveis, desenvolvidas na interação com a comunidade (FBB, 2015).

A TS implica um modo próprio de pensar e agir, com um foco na sociedade, levando em conta valores, como a inclusão social, o respeito ao meio ambiente e o processo democrático. O Instituto de Tecnologia Social (2007:15) descreve a TS por meio de um conjunto de 12 características: 1. compromisso com a transformação social; 2. criação de um espaço de descoberta de demandas e necessidades sociais; 3. relevância e eficácia social; 4. sustentabilidade socioambiental e econômica; 5. inovação; 6. Organização e sistematização; 7. acessibilidade e apropriação das tecnologias; 8. um processo pedagógico para 
todos os envolvidos; 9. Diálogo entre diferentes saberes; 10. Difusão e ação educativa; 11. Processos participativos de planejamento, acompanhamento e avaliação; e 12. construção cidadã do processo democrático.

Contudo, segundo o mesmo Instituto, a TS não possui e nem pode haver uma fórmula metodológica, fixa e imutável, porque se dá na construção participativa para que seja sustentável, e na existência de uma massa critica local vigilante às intenções de não expansão do capital, assegurando o bem estar das pessoas e do ambiente. Nesse sentido, o movimento de TS tem demonstrado resultados positivos na solução de problemas sociais em localidades diversas, tanto pela sua dimensão de fortalecimento da democracia e da cidadania, quanto pela disseminação de conhecimentos reaplicáveis, através do processo de desenvolvimento participativo e cooperativado, respeitando o saber popular.

A tecnologia social tem sua origem reconhecida no movimento de resistência, da década de 60 e 70, que promovia uma tecnologia intermediária entre a realidade dos países capitalistas centrais e os de periferia. $\mathrm{O}$ movimento tinha como fundamento, segundo Dagnino et a.l, (2004, p.14), o pensamento de reformadores da sociedade Indiana, do século XIX, destacando-se a figura de Gandhi, preconizador da reabilitação das tecnologias tradicionais, enaltecendo a roca de fiar, de forma estratégica na luta contra a colonização britânica. Apesar do movimento ter tido como símbolo a roca de fiar, não intentava uma conservação estática das tecnologias tradicionais, havia o interesse por uma política científica e tecnológica moderna, voltada ao melhoramento das técnicas locais e transformação da sociedade hindu, mas que, necessariamente, fosse realizada a partir de dentro daquela sociedade, por adequação sociotécnica, e não através de uma imposição externa e determinista advinda de países tecnologicamente desenvolvidos..

Contudo, gradativamente, o conceito de tecnologia social veio sendo construído como um movimento científico-político-social que objetiva incentivar a comunidade cientifica a ampliar, cada vez mais, suas ações às demandas de uma camada da população que necessita atenção básica. 


\subsection{1.}

\section{A tecnologia social no Brasil}

No início de 2000, surge no Brasil o movimento de tecnologia social (TS), alavancado por um grupo de atores da sociedade civil, não vinculados somente às temáticas da ciência, mas essencialmente preocupados com o crescente estado de emergência social do país. O movimento arrastava a experiência da construção coletiva do conhecimento

Suas origens são reconhecidas pelos movimentos das Tecnologias Intermediárias de Schumacher (1973) e da Tecnologia Apropriada (TA) da década de 1970. Segundo Dagnino et al. (2010: 16), os debates sobre TS pegaram o fluxo dos movimentos das Redes de Economia Solidária (RESs) (FBES, 2001), das Incubadoras Tecnológicas de Cooperativas Populares (ITCPs) (ITCP, 1999), das empresas recuperadas e dos empreendimentos auto gestionários (Facultad Abierta da Facultad de Filosofia y Letras da Universidad de Buenos Aires, 2007).

Nas palavras de Otterloo (2010), o movimento já se apresentou, desde seu início, em forma de rede, denominado como RTS - Rede de Tecnologia Social, de organização proativa, coletiva, solidária e democrática, que primava por reconhecer a produção de tecnologias não direcionadas ao mercado, mas às necessidades humanas, com claro enfoque na inclusão social por geração de trabalho e renda, integrando educação, saúde, participação e cultura. A força da RTS era reconhecida e validada pelo caráter de sua formação coletiva - de instâncias governamentais e não governamentais como: governo, empresas estatais, organizações da sociedade civil e universidades públicas.

No Brasil, a prática da TS vem sendo reconhecida, desde 2000, por um grupo de atores diversos da sociedade civil, formadores da RTS - Rede de Tecnologia Social. No ano seguinte, em 2001, também surge, uma iniciativa pela Fundação Banco do Brasil (FBB).

A FBB incrementou suas ações criando o programa Banco de Tecnologias Sociais (BTS), passando a investir na captação e difusão de modelos já implementados e reaplicáveis. Surgiram outras iniciativas que se mantém até hoje, como a do Instituto de Tecnologia Social (ITS, 2001) desde 2001 e, em 2005, da Rede de Tecnologia Social - RTS (Rodrigues e Barbieri, 2008) (RTS, 2005) 
ambos originados por um conglomerado de instituições e representantes da sociedade civil.

Em agosto de 2004, foram formados Grupos de Trabalho, responsáveis pelo aprofundamento dos debates pela construção dos conceitos e a estruturação de uma rede de instituições públicas e privadas ligadas ao tema da tecnologia social. Em novembro de 2004, foi realizada, na cidade de São Paulo, a $1^{\text {a }}$ Conferência Internacional e Mostra de Tecnologia Social. As reuniões com os primeiros interessados em participar do debate, principalmente universidades e instituições do terceiro setor, proporcionou um avanço na compreensão do tema e contribuiu para o início das discussões sobre a tecnologia social e sua entrada na agenda de políticas públicas do Brasil (MCT, 2014).

A Rede de Tecnologia Social - RTS se sobressaiu diante das demais iniciativas, por ter uma organização articulada por rede, formada com instituições públicas e privadas, que desde o início definiu critérios para apoiar e priorizar a geração de trabalho e renda em territórios que mais careciam de apoio para a promoção do desenvolvimento local, dentre eles: Amazônia Legal, Periferias de grandes centros urbanos, Semiárido/Sertão do São Francisco e Cerrado (RTS, 2005).

Em 2011, a RTS ampliou o foco prioritário, passando a atuar na reaplicação, difusão e desenvolvimento de tecnologias sociais de gestão sustentável de recursos hídricos e florestais; produção de energia limpa e busca permanente de eficiência energética; produção de alimentos saudáveis; produção de habitações e infraestruturas; educação, formação e geração de trabalho e renda por meio de negócios.

Em se tratando de ações determinadas por políticas publicas no Brasil, de acordo com a Secretaria de Ciência e Tecnologia para Inclusão Social, do Ministério de Ciência e Tecnologia, em entrevista, via email, solicitada por esta pesquisadora, no ano de 2014:

[...] as primeiras discussões em torno do que hoje convencionou chamar de Tecnologia Social como proposta de política pública começaram em julho de 2004 a partir dos debates sobre extensão tecnológica, tecnologias apropriadas e da abordagem crítica em torno das tecnologias convencionais e do processo de exclusão social associado a estas.

Segundo Soares e Arruda (2014), a TS vem influenciando fortemente as políticas públicas no país, tanto que há esforços do governo na adoção e adaptação 
de fundos para construir e disseminar a TS. As principais áreas dos atuais investimentos para TS's no Brasil estão voltadas para a região do semiárido, prevenção de desastres naturais, segurança alimentar, educação, energia, habitação, geração de renda, saúde e ambiente (Soares e Arruda, 2014:2-3).

A TS legitima-se perante suas ações junto às camadas mais excluídas da sociedade por apresentar alternativas atualizadas do campo científico, de simples execução e de baixo custo, que solucionam problemas estruturais e de atenção básica. Quanto ao acesso da população às tecnologias sociais, o MCT (Anexo I) esclarece que é favorecido por meio de projetos de extensão, de desenvolvimento, de reaplicação e de capacitação em tecnologia social, bem como pelo fomento à instituições de pesquisa, entidades da administração pública direta e indireta e de organizações sociais sem fins lucrativos com comprovada experiência na área. Contudo desde 2004, alguns projetos já se transformaram em políticas públicas, como:

1. O PAIS - Produção Agro ecológica Integrada e Sustentável, dirigido às necessidades de segurança alimentar (consumo local) e a geração de renda através da comercialização do excedente.

2. O Programa Nacional de Alimentação Escolar (PNAE), do Fundo Nacional de Desenvolvimento da Educação (FNDE) é uma ação amparada pela Lei 11.947, de 16 de junho de 2009, que dispõe sobre o atendimento da alimentação escolar e estabelece que do total dos recursos financeiros repassados às escolas, no mínimo $30 \%$ deverão ser utilizados na compra de alimentos diretamente da agricultura familiar.

3. O Projeto "Cisterna de Placas", pensado para minimizar o problema da seca no Nordeste. A metodologia é simples, desenvolvida em interação com a comunidade e que há mais de 10 anos vem sendo reaplicada por entidades da sociedade civil ligadas à Articulação no Semiárido Brasileiro (ASA).

4. Exemplo similar, direcionado à mesma região, é o programa Água Para Todos que proporcionou a construção de 60 mil cisternas de placas em parceria com os movimentos sociais. 


\subsection{2. \\ Experiências projetuais em tecnologia social: o projetar, produzir e distribuir}

A análise dos projetos em tecnologia social considerou as questões operacionais e metodológicas, a contribuição de cada experiência no que tange a atenção dada e os resultados obtidos nas dimensões sociais, culturais, políticas, econômicas e ambientais (Sachs, 2004). Foram formuladas as seguintes perguntas:

1. O que é a tecnologia social?

2. Qual a demanda da TS?

3. Como iniciou o processo de desenvolvimento da TS no lugar?;

4. Qual o método utilizado?

5. Como financiam o projeto?

6. Como funciona a TS?

7. Como é formada a cadeia de insumos?

O levantamento de projetos de tecnologias sociais foi realizado com base em duas fontes: 1) o banco de dados da Fundação Banco do Brasil (FBB), reconhecido pela sociedade como o banco mais atualizado, promovendo o premio anual de tecnologia social; e 2) Projetos fomentados por outras fundações de organizações privadas, cadastradas no Banco da FBB, como a Fundação Vale, parceira do Centro Popular de Cultura e Desenvolvimento..

A busca no Banco da FBB utilizou a formatação do sistema do banco que esta organizado por 8 temas principais (Alimentação, Educação, Energia, Habitação, Meio ambiente, recursos hídricos, renda e saúde). Foram consultados todos os projetos de cada tema principal, tendo sido selecionados aqueles que desenvolveram um produto (objeto) para atenção básica. Foram analisados 7 projetos de tecnologia social. Alguns dos projetos apresentam tecnologias acopladas, como os da construção civil que propõem casas + banheiro seco + pintura com tinta de terra.

Quanto a primeira pergunta, foram identificadas soluções relacionadas a: construção civil (3 cisternas, 1 banheiro seco, 1 pintura com tinta de terra) e; alimentação ( 2 canteiros produtivos, 1 fogão solar, e 1 Biodigestor em escolas como fonte de energia para cozinha).

Não foi identificada a fabricação de produtos de uso individual e de larga escala produtiva, como o calçado escolar. Quanto aos meios de produção, é 
priorizado o artesanal, de preferência optando por mão de obra de profissionais com habilidades tradicionais locais (artesão utilitário) como: pedreiros, perfuradores de poço, agricultores familiares e pintores. A cadeia de fornecimento de insumos é estabelecida com o mercado do próprio território, ou fornecidas artesanalmente por conhecimentos tácitos apresentados pela própria comunidade, com a utilização de resíduos ou matéria-prima do ambiente local. A inovação tecnológica é introduzida pela instituição de pesquisa participante ou trazidas por organizações não governamentais, mas o seu desenvolvimento completo depende da participação da comunidade local.

A segunda pergunta retrata a demanda de atendimento das tecnologias sócias. Quanto a construção civil: 3 cisternas = 921 famílias e 43 comunidades escolares, e 1 banheiro seco $=110$ famílias atendidas, 01 pintura com tintas de terra $=110$ famílias atendidas; Alimentação: 02 canteiros produtivos $=260$ famílias atendidas, 1 fogão solar = Apesar de apresentar dados da fase experimental, durante os 81 dias de operação da Cozinha Escola Experimental Solar - CEES, de agosto a dezembro de 2009, em torno de 5.600 pratos foram preparados, dos quais $75 \%$ foram cozidos exclusivamente com energia solar, e 1 biodigestor em escolas como fonte de energia para cozinha $=$ Como experimento foi possível atender 2.000 alunos, como multiplicadores ambientais e através da geração de 12 mil reais de economia anualmente para escola, podendo, com isso, aumentar os recursos para merenda, livros e demais recursos necessários.

Em destaque, os 2 projetos, o Programa Um Milhão de Cisternas (P1MC) e do Programa Uma Terra e Duas Águas $(\mathrm{P} 1+2)$, propostos pela Articulação Semiárido Brasileiro (ASA), se transformaram em política publica, com apoio e envolvimento dos agricultores e das agricultoras nos processos de mobilização e educação promovidos pela ASA, que segundo Nogueira (2014) foi a base para a construção de políticas públicas emancipatórias.

Foi identificado que as tecnologias sociais, das cisternas escolares (banheiro e higiene do ambiente) e de produção (para uso nos sistemas de permacultura escolar, cozinhar e beber). bem como os canteiros e o banheiro seco tiveram replicabilidade em outros contextos sociais, mantendo as mesmas características, contudo resguardadas as diferenças entre ofertas e demandas territoriais de implantação: formação do capital social que legitima e apoia a governança local, os conhecimentos tácitos em oferta de mão de obra, que quando não existente são 
necessárias capacitações locais para produção da tecnologia social e variabilidade na oferta de matéria-prima.

A sensibilização da população local para um trabalho participativo é fundamental para iniciar o processo de implantação da TS, e a ação que demonstrou maior efeito positivo foi iniciar a formação do capital social, com a participação de agentes locais. A analise identificou que não foram implementados movimentos sociais para esta ação, tendo sido considerados movimentos locais já existentes, tanto governamentais (municipais), não governamentais, instituições religiosas, fundações de Empresas com atividades econômicas no território, grupos escolares ou grupos informais locais como de agricultores familiares ou pedreiros (trabalhadores de oficio tradicional da construção civil). Entretanto, como motivadores para iniciar o projeto no local foram identificadas a participação de organizações não governamentais, governamentais e instituições religiosas.

A análise mostrou que as TS’s possuem uma base de inovação tecnológica por produto e processo, que sofre alteração de acordo com a participação da população no desenvolvimento de alternativas para implantação no território, o que se chama conceitualmente como adequação sociotécnica (Dagnino, 2006). Nesse sentido, o trabalho é participativo, desenvolvido a partir da realidade de cada comunidade, sendo para isso realizadas reuniões nas comunidades para explicação sobre o princípio de funcionamento dos projetos. São realizadas capacitações para formação de multiplicadores da TS no território.

\subsection{3.}

\section{Avaliação final das experiências projetuais em tecnologias sociais}

As análises das experiências em tecnologias sociais demonstraram que os métodos de trabalho são auto-gestionários ou por grupos de trabalho temáticos, demonstrando haver as alavancas para a realização da inovação tecnológica social, conforme figura 6. Entretanto, seu formato de rede de atores é tipicamente de extensão do tipo universidade-comunidade, sem preocupação com seu desdobramento. Alguns são em Tríplice Hélice (universidade-comunidadeempresa) e nenhum do tipo Tríplice Hélice Dupla, que seria mais favorável pois teria o caráter sustentável. Desta forma, a universidade ainda fica com o papel de motivadora dos processos de implantação e adequação da tecnologia junto às 
comunidades; a comunidade fica no papel de receptora e agente participativo no processo de aprendizagem dos processos e implementação da tecnologia, e a empresa como parceira econômica, quando o projeto possui fomento de Fundações Empresarias, vinculados as suas ações de Responsabilidade Social Corporativa. A participação do governo como responsável pela demanda social não foi identificada, contudo apresentou-se como parceiro nos projetos que se transformara em políticas públicas, após longo percurso de desenvolvimento pela sociedade.

Também não foi identificada nenhuma estratégia de inovação para o desenvolvimento tecnológico contínuo nos locais. As tecnologias sociais não mostraram cooperação entre aglomerações produtivas locais (APL's), até porque a cadeia de suprimentos dos projetos é configurada a partir de insumos produzidos artesanalmente ou comprados no mercado local. Ou ainda, quando possuem fomento de Fundações Empresariais, são realizados convênios com empresas para compra de pouca quantidade de componentes de fabricação industrial, como o caso das cisternas escolares: cimento e as tubulações.

Dentre as tecnologias sociais, não há comercialização de produtos, apenas difusão do conhecimento para uso na comunidade em situação de necessidade. Os processos artesanais mostram prioridade no desenvolvimento local da tecnologia, com forte apelo para a valorização do saber tácito em complemento ao técnicocientífico.

Fica claro que as propostas, analisadas nesta tese, focam a engenharia civil (80\% dos projetos). O método geralmente empregado é apresentar para a população a técnica que a academia desenvolveu, juntar as pessoas para finalizar o desenvolvimento da tecnologia e capacitá-las para produzir eles mesmos com material local. Não transferem para produção em larga escala, é praticamente artesanato, pois os projetos são replicados com alterações locais.

Considerando a necessidade de atendimento a outras necessidades básicas, e de forma a conciliar o projeto de produto/serviço para atendimento em larga escala, foi feito o estudo de um framework para design que contemple questões sociais e técnicas com abrangência nacional, que é apresentado no capítulo a seguir. 


\section{8.}

\section{Conclusão do capítulo}

A contribuição deste capítulo se expressa no entendimento de que os processos de inovação são imprescindíveis para o desenvolvimento de uma Nação, desde que a inovação tecnológica amplie seu conceito para as dimensões da sustentabilidade, consideradas pelos modelos de cooperação entre atores, reconhecidos como Tripla Hélice Dupla, onde o governo, as empresas, as universidades e a sociedade são os atores com responsabilidade compartilhada. Contudo, foi identificado, sob a perspectiva do design, que se este formato for envolto pelas relações das alavancas estratégicas para vantagens competitivas sustentáveis, apresentada por Freire (2014), é possível definir uma estrutura capaz de desenvolver uma inovação voltada a atender necessidades sociais complexas de abrangências macro ou micro. A composição dos atores em rede é o que vai permitir sua abrangência de ação, especialmente quando se trata de contribuir no atendimento as necessidades básicas de populações de baixa renda dentro de seus territórios.

Quanto a relação do design com a tecnologia social, pode-se afirmar que não são excludentes porque, reconhece-se por tecnologia social do design uma ação com base em procedimentos técnicos teórico-metodológicos do design, em parceria, com as técnicas provenientes do saber popular. Contudo nem toda ação do design social pode ser reconhecida como tecnologia social. 


\section{3 SISTEMA DE PROJETAÇÃO, PRODUÇÃO E DISTRIBUIÇÃO DE PRODUTOS DE MEDIA COMPLEXIDADE PARA ATENÇÃO BÁSICA}

Este capítulo foca o objetivo geral desta tese que é desenvolver um sistema de projetação, produção e distribuição local de produtos/serviços capazes de suprir necessidades básicas de indivíduos necessitados de qualquer localidade no Brasil,. A variabilidade de contextos sociais, ambientais e culturais do público-alvo a ser atendido, pela perspectiva do design (Lobach, 2001, p. 54) e da produção distribuída (Kühnle, 2010; Whang e Shen, 2007) impacta, respectivamente, na configuração (física e cognitiva) do produto e nos parâmetros de planejamento da produção (grau de padronização e tipo de operação), distribuição e consumo. Nesse sentido, a estrutura deste capítulo foi formatada em três fases, conforme figura 13, de modo a explicitar a construção do modelo básico de sistema de projetação e produção distribuída (SPPD) de produtos de atendimento básico.

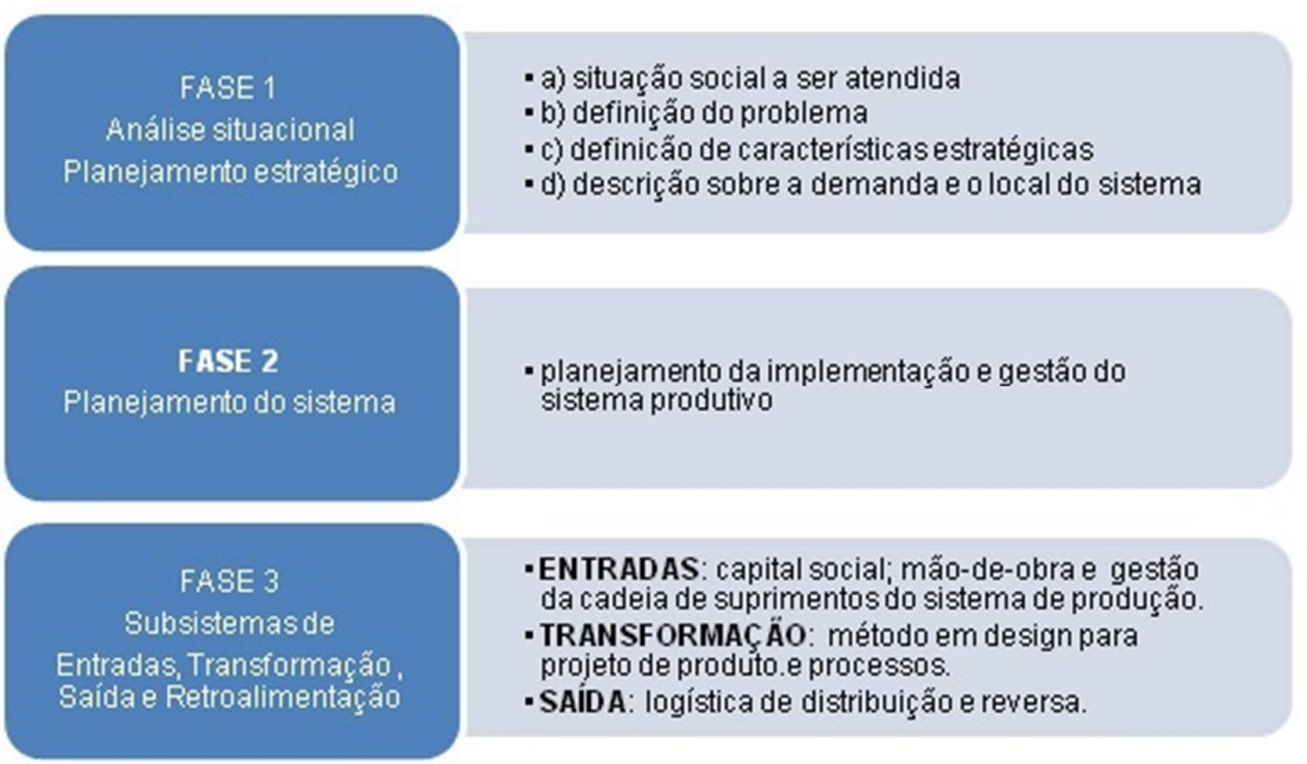

Figura 13 - Estrutura do Capítulo com as 3 grandes Fases do modelo proposto para projetação e produção distribuída (SPPD) de produtos de atendimento básico. 
A Fase 1 está composta pela Análise da situação social a ser atendida, a problematização, a descrição das características estratégicas, a demanda e o local do sistema. A Fase 2 engloba o planejamento da implementação e gestão do sistema produtivo. A Fase 3 incorpora o subsistema de entrada, com os recursos para manufatura; o subsistema de transformação, com o método em design para projeto de produto e processos; e o subsistema de saída, com a logística de distribuição do produto, e a de retroalimentação, enfatizando a ampliação do ciclo de vida do produto com a possibilidade de fazer manutenção durante o uso, bem como, a logística reversa, com o take back do produto e a reciclagem dos componentes.

\section{1.}

Análise da situação social a ser atendida, problematização, descrição das características estratégicas, da demanda e do local do sistema (Fase 1)

\subsection{1.}

Análise da situação social a ser atendida

O primeiro passo do método é a descrição da demanda social ou a situação a ser atendida, para garantir que seja priorizada a investigação da situação a ser resolvida ao invés de tomar como parâmetro soluções já existentes que talvez não sejam compatíveis com o que as pessoas precisam para alcançar um estado de sustentabilidade e bem viver em suas vidas.

\subsection{2.}

\section{Definição do problema}

O segundo passo é a definição do problema que subdivide-se em compreender o problema social de atenção básica por três estágios da situação vivida: 1) urgência, quando há total ausência de produtos ou serviços no atendimento à população; 2) manutenção, quando a população já ultrapassou a barreira da miséria e indigência, e já está suprida com o mínimo e pode usar suas capacidades para manter o processo de desenvolvimento humano, focando no ultimo estágio; 3) o sustentável. 
Nesse processo de atendimento, é imprescindível que todas as dimensões da sustentabilidade: a social, a ambiental, a territorial ${ }^{16}$, a econômica e a política ${ }^{17}$ (Sachs, 2004, p. 15), estejam sendo levadas em consideração no plano de ação. Isto é um diferencial em relação a diversas experiências projetuais, já analisadas no Capitulo II: primeiro porque o plano de ação tem como meta atender os três estágios por uma dinâmica de suprimento da urgência das pessoas daquele lugar, mantendo um contínuo processo de desenvolvimento; e segundo que este processo obriga o envolvimento com o contexto social do território, na formação de um capital social com as instituições que geram conhecimento pelas suas relações de cooperação, e enquanto grupo social produtivo, a partir das habilidades e especializações complementares.

Assim, as necessidades serão atendidas até que sejam extintas, mas para que ocorra, o capital social deverá estar sempre consciente da ação contínua de desenvolvimento local. Isto para desestimular a perpetuação das iniciativas de cunho assistencialista, mitigatória ou por indução legal, que geralmente tem caráter pontual de atendimento às pessoas, e que também não oportunizam o alcance de uma situação sustentável, pois não priorizam o desenvolvimento das capacidades humanas e do coletivo no território.

Mas, ainda assim, é preciso garantir o direito legal de atendimento, porque a problemática tratada é de necessidade básica em função da inação das políticas públicas do Estado. Portanto, o Governo, em algum momento do processo, deve se tornar um stakeholder do sistema, com o papel de dar suporte institucional às ações de solução por território (Cruz e Pithon, 2009, p. 5 apud Scott, 2007; Bhattacharyya et al, 2008; ).

\subsection{3.}

Características estratégicas do SPPD

O sistema proposto possui três características, reconhecidas como estratégicas, porque consistem em gerar e orientar as condições e recursos para que a estrutura do sistema seja desenvolvida segundo os objetivos desta tese. A

16 Territorial- relacionada à distribuição espacial dos recursos, das populações e das atividades;

17 Politica - a governança democrática é um valor fundador e um instrumento necessário para fazer as coisas acontecerem; a liberdade faz toda a diferença (Sen, 2000) 
primeira refere-se à responsabilidade governamental de atender as necessidades básicas de populações vivendo situações de urgência; a segunda retrata a oportunidade de contribuir com o desenvolvimento local de territórios atendidos; e a terceira, promove um movimento de inovação tecnológica social (dos produtos e processos), realizado por 2 vertentes:

A) Quando a estrutura em que os agentes formadores da Tríplice Hélice Dupla para a sustentabilidade (empresa-universidade-governo-sociedade), entram em movimento de co-diálogo (Zurlo, 2010), co-design (Meroni, 2008) ou consenso auto-gestionário (Albuquerque, 2014, p. 393), impulsionados por um movimento elíptico com origem de força nas suas arquiteturas e reputações (Kay, 1993). Independente das intenções individuais, as relações que se estabelecem transformam o modo de pensar individual e se expandem ao bem comum de um coletivo, ou seja, a inovação tecnológica social, proposta no Capitulo II, figura 6, voltada a atender necessidades sociais complexas de abrangências macro ou micro, não dependente da origem geográfica, nem da abrangência, mas da relação especializada e de habilidade à inovação. Contudo fortalecidas quando ocorrem entre agentes sociais do mesmo território.

B) Quando há descentralização dos processos produtivos entre atores, geograficamente dispersos, contudo integrados pelos sistemas de informação porque são configurados pelo conceito de produção distribuída (PD) (Kühnle, 2010; Whang e Shen, 2007).

Estas características e vertentes configuram um diferencial deste sistema, seu formato aberto e capacidade de customização no espaço virtual (a distância) e territorial (in loco). Em relação às experiências projetuais analisadas no Capitulo II, desta tese, e apresentadas, na figura 14, que é um resumo organizado das iniciativas mais recorrentes e diversas quanto: ao produto desenvolvido, a necessidade atendida, a escala de produção e ao tipo de distribuição à comunidade. 


\begin{tabular}{|c|c|c|c|c|}
\hline \multicolumn{5}{|c|}{ Quadro Comparativo entre propostas projetuais para atendimento de necessidades básicas } \\
\hline \multicolumn{5}{|c|}{ Propostas em Designing for emerging market (Delft University of technology) } \\
\hline $\begin{array}{l}\text { Iniciativa } \\
\text { Institucional }\end{array}$ & Produto & $\begin{array}{l}\text { Necessidade } \\
\text { atendida }\end{array}$ & $\begin{array}{l}\text { Escala de } \\
\text { produção }\end{array}$ & $\begin{array}{l}\text { Distribuição à } \\
\text { comunidade }\end{array}$ \\
\hline \multirow{3}{*}{$\begin{array}{l}\text { Empresa } \\
\text { Holandesa- } \\
\text { Delft University of } \\
\text { Technology- } \\
\text { Comunidade ou } \\
\text { Governo de países } \\
\text { em } \\
\text { desenvolvimento. } \\
\text { Pela lógica THDS. }\end{array}$} & Lanterna & $\begin{array}{l}\text { Iluminação } \\
\text { doméstica } \\
\text { (energia) }\end{array}$ & \multirow{3}{*}{$\begin{array}{l}\text { Larga escala* } \\
\text { com fabricação } \\
\text { industrial) }\end{array}$} & \multirow{3}{*}{ Venda } \\
\hline & Óculos & $\begin{array}{l}\text { Visão - } \\
\text { correção } \\
\text { (saúde) }\end{array}$ & & \\
\hline & Fogão & $\begin{array}{l}\text { Alimentação e } \\
\text { saúde }\end{array}$ & & \\
\hline \multicolumn{5}{|c|}{$\begin{array}{l}\left({ }^{*}\right) \text { Larga escala - fabricação industrial de produtos para atender grande quantidade de usuários. } \\
\left({ }^{\star \star}\right) \text { Escala territorial - fabricação com mão de obra local, não significando ser pequena escala, apenas que } \\
\text { garanta o atendimento suficiente aos usuários locais. Deve satisfazer fatores culturais, ambientais. e } \\
\text { desenvolvimento local. }\end{array}$} \\
\hline \multicolumn{5}{|c|}{ Proposta dos Projetos em Tecnologias Sociais } \\
\hline Iniciativa & produto & $\begin{array}{l}\text { Necessidade } \\
\text { atendida }\end{array}$ & $\begin{array}{l}\text { Escala de } \\
\text { produção }\end{array}$ & $\begin{array}{l}\text { Distribuição a } \\
\text { comunidade }\end{array}$ \\
\hline \multirow{4}{*}{$\begin{array}{l}\text { ONG's } \\
\text { Projetos em } \\
\text { Tecnologias sociais } \\
\text { no Brasil } \\
\text { Pela lógica da } \\
\text { Tríplice Hélice ou } \\
\text { Universitária: } \\
\text { pesquisa-ensino- } \\
\text { extensão. }\end{array}$} & $\begin{array}{l}\text { Cisterna } \\
\text { domestica }\end{array}$ & $\begin{array}{l}\text { Água potável } \\
\text { Áqua para }\end{array}$ & \multirow{4}{*}{$\begin{array}{l}\text { Capacidade de } \\
\text { replicabilidade*** } \\
\text { em outros } \\
\text { contextos sociais, } \\
\text { por território } \\
\text { (coletivo local). } \\
\text { Os insumos são } \\
\text { adquiridos no } \\
\text { mercado local, } \\
\text { reutilização de } \\
\text { resíduos ou } \\
\text { produzidos } \\
\text { artesanalmente } \\
\text { (Ex. tintas de } \\
\text { areia). }\end{array}$} & $\begin{array}{l}\text { População fez em } \\
\text { coletivo. Fomento }\end{array}$ \\
\hline & $\begin{array}{l}\text { Cisterna } \\
\text { escolar }\end{array}$ & $\begin{array}{l}\text { produção de } \\
\text { alimentos } \\
\text { (Saúde) }\end{array}$ & & $\begin{array}{l}\text { com Fundo } \\
\text { solidário e } \\
\text { subsídios do } \\
\text { governo federal }\end{array}$ \\
\hline & Fogão solar & $\begin{array}{l}\text { Alimentação } \\
\text { (energia) }\end{array}$ & & $\begin{array}{l}\text { Faça você } \\
\text { mesmo. }\end{array}$ \\
\hline & $\begin{array}{l}\text { Casa } \\
\text { Saudável }\end{array}$ & $\begin{array}{l}\text { Cisterna - água } \\
\text { potável e } \\
\text { produção } \\
\text { (alimentação); } \\
\text { Reformas - } \\
\text { pintura com tinta } \\
\text { natural (areia } \\
\text { colorida); } \\
\text { Banheiro seco } \\
\text { (Saúde) }\end{array}$ & & $\begin{array}{l}\text { População fez em } \\
\text { coletivo. Fomento } \\
\text { de fundação } \\
\text { empresarial. }\end{array}$ \\
\hline \multirow{2}{*}{\multicolumn{5}{|c|}{$\begin{array}{l}\left({ }^{* *}\right) \text { Replicabilidade- significa que a tecnologia desenvolvida com a comunidade, tem capacidade de } \\
\text { reprodução em comunidades diversas. Não há fabricação industrial dos insumos, são técnicas artesanais locais } \\
\text { e/ou adquiridos no mercado local. Atende o conceito de TS: necessariamente reaplicáveis, de baixo custo e } \\
\text { desenvolvidas na interação com a comunidade (FBB, 2015). } \\
\text { PROPOSTA DA TESE: SPPD de produtos para atencão básica }\end{array}$}} \\
\hline & & & & \\
\hline Iniciativa & roduto $^{18}$ & $\begin{array}{l}\text { Necessidade } \\
\text { atendida }\end{array}$ & Escala de produção & $\begin{array}{l}\text { Tipo de } \\
\text { distribuição à } \\
\text { comunidade }\end{array}$ \\
\hline 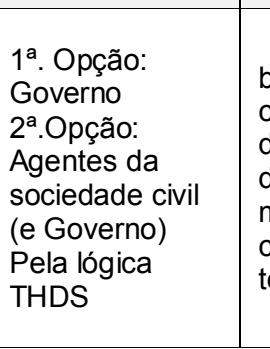 & $\begin{array}{l}\text { ens de } \\
\text { onsumo } \\
\text { uráveis e semi- } \\
\text { uráveis, de } \\
\text { édia } \\
\text { omplexidade } \\
\text { cnológica. }\end{array}$ & $\begin{array}{l}\text { segurança, } \\
\text { higiene, } \\
\text { proteção da } \\
\text { saúde, auxilio } \\
\text { na vida diária. } \\
\text { vestuário, } \\
\text { educação e } \\
\text { lazer }\end{array}$ & $\begin{array}{l}2 \text { perfis: 1)Larga } \\
\text { escala tem demanda } \\
\text { nacional - fabricação } \\
\text { industrial insumos. (2) } \\
\text { Escala territorial } \\
\text { demanda cultural e } \\
\text { ambiental local (meio } \\
\text { artesanal e industrial } \\
\text { de fabricação). }\end{array}$ & $\begin{array}{l}\text { Venda por } \\
\text { comércio justo. } \\
\text { No estágio de } \\
\text { urgência cabe } \\
\text { ao responsável } \\
\text { pela iniciativa } \\
\text { distribuir } \\
\text { gratuitamente } \\
\text { até findar a } \\
\text { situação. }\end{array}$ \\
\hline
\end{tabular}

Figura 14 - Quadro comparativo entre propostas projetuais para atendimento de necessidades básicas de populações

18 Produto para atenção básica: reconhecido pelo usuário e de projeto parametrizado pelas especificações técnicas de segurança ao uso. 
A primeira característica do sistema, denominada Responsabilidade Governamental, dá ênfase à obrigatoriedade do Estado em atender as necessidades básicas das populações vivendo situações de urgência, entendida como situação de pobreza expressa pela ausência de condições básicas para a vida como: água potável, alimentação, abrigo, saúde, educação, liberdade, segurança e lazer, conforme estabelecido por Lei (Artigo XXV, da Declaração Universal dos Direitos Humanos, 1948; Constituição do Brasil de 1988, em seu Capítulo II Dos Direitos Sociais, artigo $7^{\circ}$, inciso IV). Esta característica não foi encontrada nas experiências projetuais analisadas no Capítulo II.

Dentre os projetos investigados, apenas 1 de tecnologia social apresenta uma iniciativa governamental para Assistência Social executada como política pública $^{19}$ (Angola, 2009): o projeto Cisternas Escolares, que faz parte do Programa Um Milhão de Cisternas (P1MC) que pertence ao Programa Uma Terra e Duas Águas $(\mathrm{P} 1+2)$, proposto pela Organização não governamental Articulação Semiárido Brasileiro (ASA). Entretanto, não se identifica a necessidade de programas de políticas públicas específicas para a implantação deste projeto, pois existem modalidades para compra pública que dispensam licitação, conforme disposto no Capitulo II, da Lei $\mathrm{n}^{\circ} 8.666$ (Brasil, 1983), tal como citado pelo Inciso XXXIII, da mesma Lei, no Art. 24:

na contratação de entidades privadas sem fins lucrativos, para a implementação de cisternas ou outras tecnologias sociais de acesso à água para consumo humano e produção de alimentos, para beneficiar as famílias rurais de baixa renda atingidas pela seca ou falta regular de água.

Ou ainda, como citado no Artigo 14, $\S 1^{\circ}$, da Lei n ${ }^{\circ} 11.947 / 2009$ e Artigo 18, $\S 1^{\circ}$, da Resolução $\mathrm{n}^{\circ} 38$, com procedimentos específicos, estabelecendo prioridades para contratar em razão das características do fornecedor.

Esta modalidade de compra pública foi o que permitiu ao Programa Nacional de Alimentação Escolar (PNAE) instituir o Programa Dinheiro Direto na Escola para aquisição de alimentos com origem na agricultura familiar, com o propósito de compor a dieta da merenda escolar de todas as escolas de ensino público do Brasil. Neste caso, quem compra a merenda são as chamadas Entidades Executoras - EEx, instituições da rede pública de ensino federal,

${ }^{19}$ Apesar de existirem outros projetos indicados pelo MCT, que se tornaram políticas públicas, mas que não foram analisados nesta tese, apenas citados no capitulo 2 . 
estadual e municipal que recebem recursos diretamente do Fundo Nacional de Desenvolvimento Escolar (FNDE) para a execução do PNAE. Estas compras podem ser feitas de forma centralizada, pelas secretarias estaduais de educação e prefeituras, ou de forma descentralizada, pelas Unidades Executoras das escolas (UEx) sendo:

entidade privada sem fins lucrativos, representativa da comunidade escolar, responsável pelo recebimento dos recursos financeiros transferidos pela EEx, em favor da escola que representa, bem como pela prestação de contas do programa ao órgão que a delegou. Considera-se também como UEx aquela constituída para execução do Programa Dinheiro Direto na Escola PDDE.

Entretanto, as UEx’s não recebem recursos diretamente do FNDE. Elas são executoras quando da opção das EEx's de descentralizar a gestão dos recursos da alimentação escolar. Como o processo é um instrumento da administração pública, que se mostrou eficiente na compra de produtos que garantam direitos fundamentais aos seres humanos, uma das opções para um sistema de produção de produto local é contar, como aglutinador do capital social, com as instituições da sociedade civil local como: entidades de classe (sindicatos), escolas e associações.

Para o capital econômico e financeiro, existem duas opções, definidas de acordo com a demanda: governamental ou de mercado local. No primeiro caso, seguiria a mesma formação que opera para a compra da merenda escolar dos agricultores familiares, evidentemente que respeitando a necessidade do direcionamento organizacional especifico a característica do produto ou serviço. No caso do calçado escolar, por exemplo, não seria uma instituição local representativa do Ministério da Agricultura, mas sim do Ministério da Educação. $\mathrm{Ou}$ então, a própria escola, representada pelo que se atualmente considera Unidades Executoras.

$\mathrm{Na}$ figura 14, com relação à $1^{\mathrm{a}}$ característica deste sistema, foram identificadas ações por iniciativa de organizações não governamentais (ONGs) que se transformaram em ações de políticas públicas. Contudo, têm abrangência regional, e não nacional, respeitando as necessidades de cada território, como também é a proposta deste sistema. Como exemplo, cita-se o Programa Uma Terra e Duas Águas $(\mathrm{P} 1+2)$, executado pela Articulação Semiárido Brasileiro (ASA). Os demais projetos foram implementados por iniciativa de organizações empresariais, com a interveniência de suas Fundações de Assistência Social ou em 
parceria com Centros Tecnológicos Universitários, demonstrando ações com perfil de filantropia e venda de produtos à comunidade. No entanto, como explica Cruz e Pithon $(2009$, p. 4; 5), a dinâmica empresarial, no que diz respeito à Responsabilidade Social Empresarial (RSE), pode extinguir tais ações sociais em prol da sobrevivência da atividade econômica da empresa, no momento de uma crise, o que tem desdobramentos não só econômicos, mas também gerenciais e sociais. Em especial, isto ocorre quando estas empresas têm suas atividades localizadas nos países em desenvolvimento, como o Brasil. Se estas práticas estiverem sendo realizadas e entendidas como o conjunto de ações deliberadas de uma empresa que busca atender aos interesses dos stakeholders envolvidos no processo, a responsabilidade compartilhada entre a empresa (acionistas, clientes, concorrentes, funcionários) e a comunidade, governo ou ONGs limita a doação de recursos e direciona o objetivo da ação para o desenvolvimento local.

Dentre as ações dos projetos analisados, não foi identificada a participação do Governo ou demais agentes da sociedade civil configurados em rede de atores, como formadores do capital social dos projetos, condição que poderia garantir a preservação do direito do atendimento de forma contínua e sustentável, sem configurar assistencialismo ou uma tradicional ação de mercado (Bhattacharyya et al., 2008).

Nesse sentido, o sistema proposto diferencia-se dos demais projetos analisados porque sua demanda refere-se à responsabilidade governamental, em projetos de assistência social para atendimento de brasileiros carentes. Entretanto, a opção motivada por ONGs ou por Fundações Empresariais também é aceita no âmbito da estrutura deste sistema, desde que o Governo e a sociedade civil (representada pelos vários agentes sociais do local) sejam componentes do Capital Social (Cruz e Pithon, 2009, p. 5 apud Scott, 2007; Bhattacharyya et al., 2008).

Este ciclo de ações, priorizando o desenvolvimento humano e local, pode ser compreendido na relação da estrutura do sistema com os 3 estágios de vivência da situação pelo público-alvo a ser atendido, e no formato proposto de atuação sob a lógica da Tríple Hélice Dupla complementares (Etkowitz e Zhou, 2006) (Figura $15)$. 


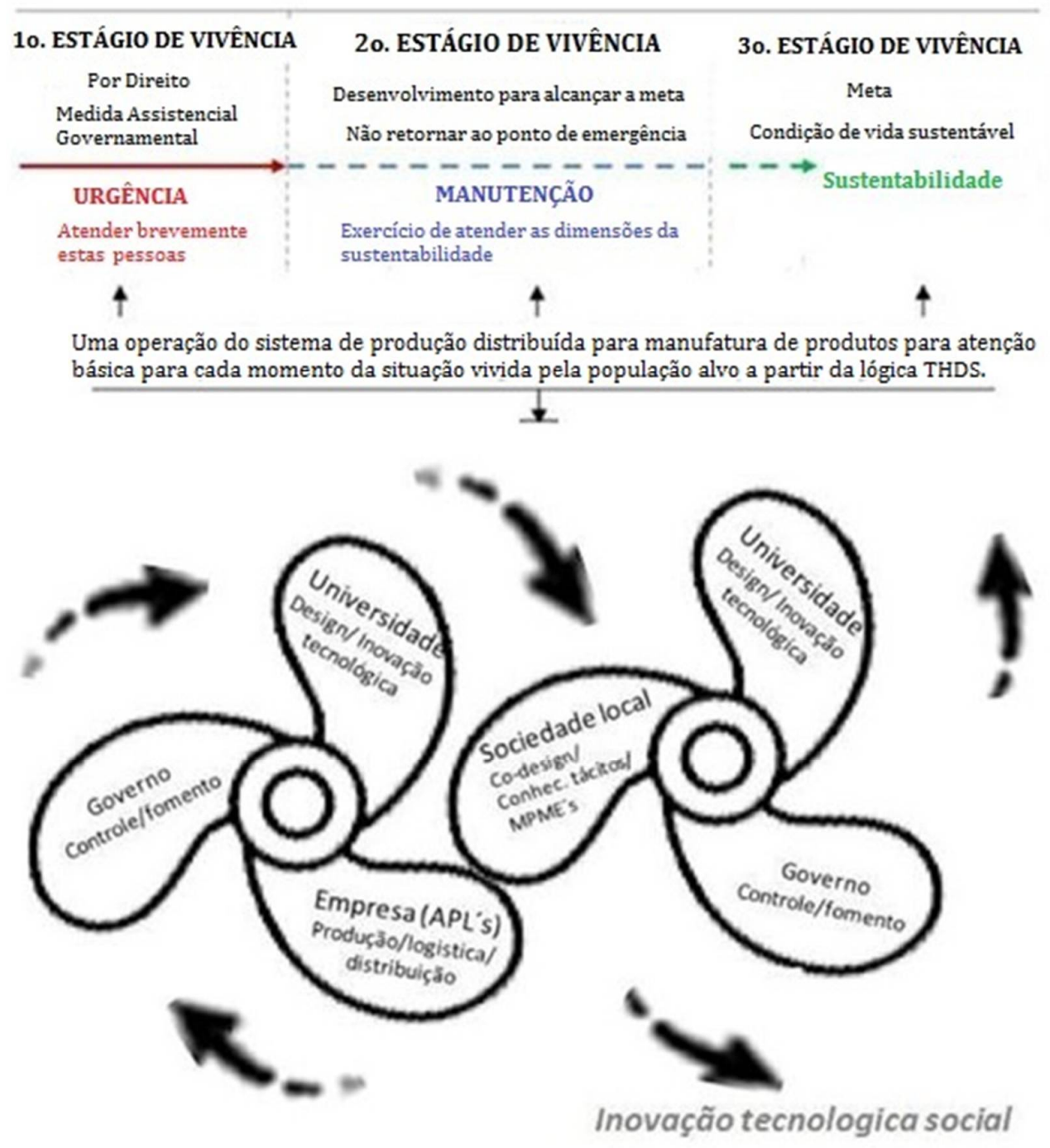

Figura 15 - Relação da estrutura do sistema com os três estágios de vivência do público-alvo (no topo) e representação gráfica da lógica da THDS, movidas pelas alavancas de arquitetura e reputação (Key, 1993).

A segunda característica, chamada de Desenvolvimento do local, trata da oportunidade de gerar trabalho e renda, sem impactar o ecossistema e valorizando os saberes e os fazeres do local, pois apesar do alto volume de produção estimado para a população brasileira, há uma demanda para produção territorial do produto. Um desenvolvimento local compreendido neste trabalho como:

[...] a organização comunitária em torno de um planejamento para o desenvolvimento, por uma perspectiva de construção social, constituindo assim um instrumento fundamental, de caráter orientador e condutor, de superação da pobreza. Não se trata, contudo, de buscar tão somente o atendimento às carências materiais, mas a identificação e a promoção das 
qualidades, capacidades e competências existentes na comunidade e no lugar (Rozas, 1998).

A demanda deste produto já é de larga escala, se for calculada pelo número de indivíduos pobres ou extremamente pobres da população brasileira (39.150.981, segundo o IPEA, 2013). No entanto, deve-se considerar que a demanda é maior, pois muitos brasileiros que não pertencem a estes extratos também não tem acesso a produtos básicos, em função das condições dos locais onde vivem. Portanto, estas pessoas serão melhor atendidas se a produção e distribuição for territorializada, já que cada região tem demandas e oportunidades diversas.

Nesse sentido, não seria a formação de uma cadeia de suprimentos do mercado tradicional local, tão pouco, somente, os conhecimentos tácitos e as habilidades de ofícios dos artesãos locais, que permitiriam satisfazer especificações técnicas de produto e processos de produção com o mínimo padrão de controle quanto: a segurança das pessoas envolvidas em todo o ciclo de vida do produto, desde a extração da matéria-prima até o pós-uso; aos impactos de sua fabricação ao ecossistema e o respeito aos fatores funcionais, simbólicos, culturais e ambientais de produto diante a variabilidade de localização, cultura e ambiente do público-alvo.

Tais especificações são exigidas por instituições de controle como o INMETRO - Instituto de Metrologia, a Associação Brasileira de Normas Técnicas - ABNT, a Política Nacional de Resíduos Sólidos, a Lei de Compras Sustentáveis, ou demais órgãos e legislações de fiscalização específicas a cada produto, portanto este sistema entende que valorizar os saberes e os fazeres do local é considerar a formação de um capital social produtivo que representa o potencial do local (industrial e artesanal) que seja capaz de satisfazer as exigências técnicas de produto e processos.

As ações projetuais (figura 14), analisadas em relação à $2^{\mathrm{a}}$ característica deste sistema, ou seja, quanto à contribuição para o desenvolvimento local de territórios atendidos, mostram-se como: ações de promoção do artesanato local; de desenvolvimento participativo de produtos entre instituições científicas e comunidades atendidas, a exemplo dos projetos de tecnologia social. Já os projetos desenvolvidos pelo grupo de pesquisa da Delft University of Tecnhology apresentam ações com a participação da comunidade para indicação de requisitos 
projetuais, atividade por eles reconhecida, como design participativo (Van Boeijen et al., 2014). Entretanto, não foi identificada a participação de agentes sociais dos locais atendidos junto às atividades de desenvolvimento de inovações tecnológicas dos produtos ou processos. Em relação à distribuição do produto, a maioria seguiu o modelo tradicional de mercado, por venda, a preços compatíveis com a capacidade de pagamento da população dos territórios atendidos, não definindo uma ação estratégica do design envolvida por cenários que retratam os interesses polissêmicos extraídos das relações dos agentes do capital social as suas necessidades para o local.

A terceira característica deste sistema, denominada de Desenvolvimento da inovação tecnológica social, é motivar a cooperação entre os agentes sociais para a inovação tecnológica de produto e processo, porque há possibilidade de propor soluções que misturem meios de produção industrial (local ou mais próximo possível geograficamente) com as habilidades dos artesãos (artesanato utilitário) para impulsionar o desenvolvimento local. A fundamentação desta característica vincula-se ao grau de padronização dos produtos que, apesar de ser de larga escala para atender uma demanda nacional, também são de escala territorial devendo satisfazer as necessidades e exigências em complexidade de produtos e processos. Uma prática que oportuniza disseminar métodos e meios de produção, segmentados pelas dimensões da sustentabilidade (Sachs, 2002), orientados para a preservação de recursos ambientais, valorização e cuidado com as pessoas e suas tradições, sem deixar de gerar trabalho e renda.

Rozas (1998) descreve este processo como uma:

... maneira de entender a realidade do que é feito com referência local para a comunidade, na qual essencialmente existem elementos compartilhados entre os membros de um grupo de pessoas; o mesmo que dizer que todos os seus membros têm uma mesma ideia geral nas vivências de cada um [...].

Desse modo, fica claro que o território será o local de operacionalização do sistema, e, portanto, o projeto do produto a ser disponibilizado terá que considerar a mediação entre fatores práticos, simbólicos, estéticos e ecológicos com a maneira local de produção e consumo, de tradição e inovação e de qualidades locais e relações globais (Krucken, 2009, p. 17). Portanto, os produtos devem ser desenvolvidos levando em consideração não somente o espaço-geográfico, mas também o espaço das experiências vividas, o "onde" das relações entre indivíduos 
com a natureza, com o espaço das relações permeadas pelos sentimentos e simbolismos do contexto social do público que irá atender (Silva, 2009, p. 109; Santos, 2000, p. 57; Krucken, 2009, p. 17; Decreto Lei de 25 de Fevereiro de 2008, Art. $\left.1^{\circ}, \S 2^{\circ}\right)$.

O produto deste sistema terá um conceito semelhante ao de produto local ou de um terroir, como denominado na língua francesa (Krucken, 2009, p. 32), porque sua fabricação estará motivada por um sistema de origem exterior ao território, promovido por uma iniciativa que não se configura "de baixo para cima" como os que foram naturalmente e historicamente concebidos no território, de manifestação cultural, representando o resultado de uma trama tecida ao longo do tempo, que envolveu recursos da biodiversidade, os modos de fazer tradicionais, costumes e hábitos de consumo. Apesar de ter em sua proposta uma relação forte ao território e à comunidade que o produzirá, sua manufatura deve ser orientada por processos promovidos pela inovação tecnológica desenvolvida em cooperação com o grupo social produtivo do lugar ou de lugares o mais próximo possível, permitindo que esta estratégia seja fundamentada pelo conceito e aplicação prática do sistema de produção distribuída (SPD), definido como a descentralização da produção, por meio de uma rede de fábricas geograficamente dispersas, mas que podem ser coordenadas por meio de tecnologia da informação (Kühnle, 2010; Whang e Shen, 2007). Que será detalhadamente descrita na Fase 3e - Modelo do processo produtivo, item 3.3.5 deste capítulo.

Assim, um dos grandes desafios deste sistema é fazer com que seu funcionamento e desenvolvimento tecnológico seja compatível com a necessidade, com o repertorio cultural e com o gosto que se expressa em cada território nacional, atendendo um conjunto complexo de variáveis, mensuráveis e não mensuráveis.

Há risco de insucesso em todos os seus propósitos, se não for realizado por um capital social representativo da sociedade civil, de abrangência territorial e nacional, e detentores de habilidades e especialidades tecnológicas complementares entre si. Este pode buscar suporte em uma realidade, já construída no Brasil desde $2004^{20}$ (Filho e Paula, 2008, p. 2; REDESIST, 2011),

20 Segundo Filho e Paula (2008, p. 2), A partir de 2004, foi instituído o Grupo de Trabalho Permanente para Arranjos Produtivos Locais (GTP/APL)3, com intuito de integrar, articular e coordenar as diversas ações voltadas para APLs. Além dessa iniciativa, foi criado a nível 
que é a dos Arranjos Produtivos Locais (APL's), um instrumento de política de desenvolvimento regional que se manifesta com uma estrutura social e produtiva capaz de suprir em recursos e minimizar os riscos da operacionalização do sistema.

Os APL s são caracterizados como:

...a evolução da simples indicação de concentração industrial geográfica de pequenos e médios produtores, para abarcar outras dimensões tais como territorialidade e especialização definidas em termos de cultura local, existência de cooperação entre MPME ${ }^{21}$ e organização institucional, formas de governança, aprendizagem coletiva, potencial de promover inovações e presença de fornecedores locais (GT Interministerial, 2004).

Desse modo, os APL's demonstram ter capacidade para fornecer suporte ao funcionamento da estrutura deste sistema porque são de abrangência nacional, com operacionalização territorial. São aglomerados de agentes com capacidade para formação de um capital social, tanto em uma iniciativa governamental para implantação do sistema, como para uma iniciativa alternativa, composta por representantes da sociedade civil local (inclusive o governo). Ainda assim, a formação tradicional dos APL's conferida às aglomerações produtivas, segundo Maciel e Albagli (2002, p. 5) permite um diferencial às questões teóricas e metodológicas no campo do estudo da inovação focada no desenvolvimento local, porque reside na existência de ambientes propícios à inovatividade sistêmica, ao conhecimento e ao aprendizado coletivo e interativo.

Cabe esclarecer que não se trata de planejar um sistema produtivo local para sítios com aglomerações especializadas na competitividade de mercados (Orlovicin e Suzigan, 2005), mas compreender que os propósitos estão focados em atender uma autodemanda territorial, por soluções para as necessidades básicas de sua população, valendo-se da mesma especialização, habilidades e vínculos produtivos, diante a proximidade geográfica das fontes de insumos, tecnologias e mão de obra, que as empresas mantém entre elas. Acrescentando,

federal o Grupo Interministerial de APL (GI), o qual, mesmo tendo sendo inicialmente uma instância informal, reunia alguns ministérios com algum grau de articulação entre si, como Ministérios do Desenvolvimento Indústria e Comércio, da Ciência e Tecnologia, do Planejamento e da Integração Nacional.

${ }^{21}$ MPME - Micro, pequenas e médias empresas. 
neste caso, uma dinâmica de desenvolvimento humano que também valorize as habilidades e as capacidades ${ }^{22}$ das pessoas do lugar.

Assim, os parâmetros de planejamento estratégico do sistema, exposto neste texto pelas suas principais características, demonstram estar de acordo com o Projeto de Política Nacional de Apoio ao Desenvolvimento Local nos territórios brasileiros (Instituto Cidadania, 2006) por assumir que:

... a possibilidade de adaptar distintas formas de desenvolvimento à ampla diversidade existente no país permite equilibrar e combinar as necessidades populacionais, ambientais e produtivas, articulando crescimento econômico com inclusão social, elevação da qualidade de vida, bem viver e sustentabilidade ambiental. Ainda assim é capaz de suprir necessidades imediatas, de descobrir ou despertar suas vocações locais, de desenvolver suas potencialidades especificas e de fomentar o intercâmbio externo aproveitando-se de suas vantagens comparativas e complementares locais.

Quanto à $3^{\mathrm{a}}$ característica deste sistema, promover um movimento de Inovação tecnológica (de produtos e processos) participativa entre os agentes sociais de interesse, foram identificadas ações nos projetos de tecnologias sociais analisados no Capitulo II. Tais projetos valorizaram um desenvolvimento tecnológico em parceria com a comunidade, pela importância de agregar o conhecimento tácito de técnicas artesanais locais, como alternativa à reaplicabilidade em outras comunidades, assegurando o baixo custo, por não priorizar a fabricação industrial dos insumos, contudo podendo ser adquiridos no mercado local ou feitos manualmente pela comunidade com recursos locais (oferta de matéria-prima) (FBB, 2015).

Não foi identificado, nas ações por iniciativas de ONG's ou de Organizações Empresariais, com interveniência de centros universitários de inovação tecnológica, o desenvolvimento cooperativo de tecnologias entre comunidade e indústria local, como vetor para a formação da cadeia de suprimentos e processos de fabricação dos produtos.

Desta forma, entende-se que esta proposta de cooperação para inovação tecnológica seria o terceiro diferencial deste sistema, pois permite satisfazer fatores do produto (funcional, simbólico, cultural e ambiental) e requisitos específicos dos processos, principalmente aqueles que focam em métodos e meios

22 Capacidades humanas - o "ser" e o "fazer" das pessoas que permite a elas viverem como gostariam (Sen, 2000, p. 4). 
de produção que preservem os recursos ambientais, a cultura pela valorização das pessoas e suas tradições sem deixar de gerar renda e trabalho. Uma proposta que se baseia nas formas naturais de organização produtiva dos territórios, onde convergem diferentes princípios de organização para o desenvolvimento econômico e social (Castioni, 2003; Senhoras, 2008; Etkowitz e Zhou, 2006), portanto um cenário que favorece um processo de aprendizagem colaborativo nas formas de interação entre os agentes sociais, tanto pelas habilidades industriais como pelo conhecimento tácito.

\subsection{4.}

\section{Demanda e local do sistema}

Este sistema foi pensado para atender populações com necessidades básicas não atendidas, que possam ser supridas por produtos dentro da área de atuação do designer. Em se tratando da realidade brasileira, a demanda é de larga escala, visto o número de pessoas necessitadas, que engloba não apenas as de baixa renda, mas também aquelas que, apesar de terem poder de compra, não são atendidas em função de habitarem regiões carentes, ou também não podem arcar financeiramente com produtos mais caros.

O local deste sistema é o território nacional, mas para localizar a operacionalizar o sistema, seu local é cada território definido pela associação da necessidade de atendimento com a disponibilidade de recursos, conferindo prioridade à localização dos Arranjos produtivos locais (APL's) distribuídos pelas regiões do Brasil: norte, sul, leste, oeste, nordeste, sudeste e centro-oeste.

Sob o aspecto do conceito de produção distribuída o local deste sistema também é virtual, porque neste caso, sua operacionalização se dá pelas redes de tecnologia da informação.

Em resumo, a demanda deste sistema é de larga escala, territorial (in loco ) e à distância (por produção distribuída) porque para funcionar e operar depende das mínimas e básicas características de cada território, que são diversas já que mudam de região para região do País. Portanto, a situação se mostra valorando proporcionalmente as dimensões da sustentabilidade no atendimento a um problema social complexo em cada território. Constitui-se em desafio ao campo do design, porque diante os três estágios de atenção a uma necessidade básica nem sempre será suficiente o re-design ou um fator incremental. 
O local ou território de implantação do sistema está constituído pelo espaço geográfico de todo território nacional, considerando o agrupamento das unidades da federação do Brasil pelas 5 regiões geográficas como: Norte, Nordeste, CentroOeste, Sudeste e Sul. Neste trabalho, ao se considerar estas territorialidades, estáse também considerando o desenvolvimento local, que é uma forma de organização comunitária para o atendimento das carências materiais locais, para a identificação e a promoção das qualidades, capacidades e competências existentes na comunidade e no lugar. Enfim, ao se considerar o território, pode-se identificar, além das necessidades, as ofertas de mão de obra, matéria-prima e meios de produção deste local, ou o mais próximo geograficamente.

\section{2.}

\section{Planejamento da implementação e gestão do sistema produtivo (Fase 2)}

Para que o sistema produtivo transforme suas entradas em produtos, ele precisa ser pensado em termos de planos e ações a curto, médio e longo prazo (Tubino, 2007, p. 1). Como este sistema já prevê a existência de três estágios (urgência, manutenção e sustentabilidade) para atender sua demanda (figura 16), é possível construir uma relação entre estes estágios e os prazos para ação do Planejamento produtivo. A figura 16 mostra esta relação que a Empresa focal deverá seguir para orientar o grupo social produtivo do local, conforme descrição do capital social, na Fase 3.

\begin{tabular}{|c|c|c|}
\hline Relaçäo entre as açöes & Curto prazo & Médio e longo prazo \\
\hline $\begin{array}{l}\text { Momento de } \\
\text { ação e objetivo }\end{array}$ & $\begin{array}{l}\text { Urgência } \\
\text { Atendimento imediato }\end{array}$ & $\begin{array}{l}\text { Manutenção e contínuo } \\
\text { de se nvolvimento humano à } \\
\text { sustentabilidade como meta }\end{array}$ \\
\hline $\begin{array}{l}\text { Atividades do } \\
\text { Planejamento e } \\
\text { Controle da } \\
\text { Produçẫo }\end{array}$ & Programação & Plano-Mestre e de Produção \\
\hline $\begin{array}{l}\text { Niveis de } \\
\text { decisấo do PCP }\end{array}$ & Operacional & $\begin{array}{l}\text { Tático e Estratégico seguindo as } \\
\text { características principais do } \\
\text { sistema proposto }\end{array}$ \\
\hline $\begin{array}{l}\text { Tipos de } \\
\text { produtos }\end{array}$ & Produtos já existentes & $\begin{array}{l}\text { Design para inovação e } \\
\text { sustentabilidade }\end{array}$ \\
\hline
\end{tabular}

Figura 16 - Prazos, atividades e objetivos para tomada de decisão no planejamento do sistema produtivo pela Empresa Focal.(a partir de Tubino, 2007, p. 1).

Em curto prazo, a empresa focal terá uma programação operacional imediata para compra de produtos já existentes. Sendo uma compra 
governamental ou de caráter público, esta deverá ser configurada por licitação atendendo, pelo menos, a necessidade de avaliação das especificações técnicas de segurança do produto. Será uma medida de urgência para amenizar o sofrimento dessas pessoas que estão em situação de carência em seu dia a dia.

Em paralelo, a implementação do sistema deverá seguir com atividades de médio e longo prazo, porque visam a manutenção ou desenvolvimento humano contínuo, com ação em cada território, para que essas pessoas não retornem ao estágio de urgência inicial.

Segundo Tubino (2007, p. 5), nas funções de planejamento e controle produtivo são previstas dinâmicas complexas, porque estão diretamente relacionadas com o grau de padronização dos produtos (diversidade de contextos sociais, ambientais e culturais do Brasil) e com o volume de produção que, no caso deste sistema, tendem a se intensificar nas ações de médio e longo prazo, apesar de estarem atendendo de forma customizada a cada território ao invés da demanda nacional.

A complexidade se apresenta nas ações estratégicas e táticas, de médio e longo prazo, porque a Empresa focal, o Governo ou o grupo de agentes sociais, não são fabricantes do produto, e sim um cliente que ao mesmo tempo exerce o papel de gestor do processo de produção pelo poder de compra e controle que possui, e definindo um planejamento do processo produtivo com características, conforme denominado por Tubino $(2007$, p.51) de Plano-Mestre de produção (PMP), considerando um sistema de produção distribuída (SPD). .

O PMP irá atuar nas táticas de operacionalização dos recursos, fazendo a conexão entre o planejamento de longo prazo (a sustentabilidade) e as atividades operacionais da produção no estágio de manutenção/desenvolvimento humano contínuo (médio prazo) definindo a operacionalidade do sistema, utilizando para isso os procedimentos legais de um processo de compras públicas.

\subsection{1.}

\section{Definição do capital social}

Atendendo as estratégias do sistema, faz-se necessário iniciar o PMP pelo processo de definição do capital social, do grupo social produtivo e de desenvolvimento da inovação, com interveniência de instituições cientificas e tecnológicas, que será composto pelas empresas fabricantes de insumos e 
produtos, bem como pelos artesãos locais, pertencentes ou não à formação dos Arranjos Produtivos Locais (APL's).

A identificação e participação dos agentes no sistema, se por iniciativa governamental ou de aglomerados de agentes sociais de implementação do sistema, dar-se-ão por audiência pública, que é o instrumento para juntar possíveis licitantes dando a oportunidade para que todos expressem suas opiniões para um certame que será proposto, o que se define como um meio de comunicação pública e transparente entre aqueles que possuem interesse em participar do sistema de produção e de suas fases de planejamento produtivo. Este instrumento sempre deverá ser utilizado nos casos de contratações de grande vulto, de similaridade entre objetos e frequência de compra.

Contudo a Empresa focal ou gestora do sistema no local deverá estimar, listar e convidar agentes sociais de relevância diante as estratégias de operacionalização do sistema.

Tendo sido formados (conforme Figura 19) o capital social e o grupo social produtivo, o segundo instrumento a ser utilizado é a Chamada Pública, um processo para formalização de dispensa de licitação, prevista nos artigos $14, \S^{\circ}$, da Lei $n^{\circ} 11.947 / 2009$ e $18, \S 1^{\circ}$, da Resolução $n^{\circ} 38$, com procedimentos específicos, estabelecendo prioridades para contratar em razão das características do fornecedor, que neste sistema tem a intenção de priorizar o desenvolvimento tecnológico customizado para as necessidades do Brasil.

A chamada pública será para formalizar os grupos produtivos do sistema: desenvolvimento tecnológico, fabricação de insumos e fabricação de produtos. Este grupo deve ser composto por agentes sociais, não importando o número de participantes, mas necessariamente deve haver um para cada etapa de implantação do sistema, com a intenção de complementar a habilidades de cada um.

Esta chamada pública seguirá os passos (figura 17 e 18) para definir os recursos para a manufatura e todo o ciclo de vida do produto (até a reciclagem), com instrumentos exigidos pela Empresa focal que serão gerenciados pelo Capital Social e executados pelo grupo social produtivo. 


\begin{tabular}{|c|c|}
\hline $\begin{array}{l}\text { Sequência de passos para } \\
\text { funcionamento do sistema tendo como } \\
\text { base os instrumentos da administração } \\
\text { pública }\end{array}$ & $\begin{array}{l}\text { Relação dos passos com as } \\
\text { considerações apresentadas pelo } \\
\text { desenvolvimento do sistema }\end{array}$ \\
\hline $\begin{array}{l}\text { "0" Passo: Análise do contexto } \\
\text { socioeconômico e político da problemática } \\
\text { social identificada como demanda para } \\
\text { assistência social. }\end{array}$ & $\begin{array}{l}\text { Ação de investigação, pesquisa, } \\
\text { levantamento de dados, analise e } \\
\text { mapeamento do contexto da problemática } \\
\text { identificada - Estudo de Caso, descrição } \\
\text { customizada das características do } \\
\text { sistema. }\end{array}$ \\
\hline $\begin{array}{l}\text { 19. Passo: Audiência Pública para mapear } \\
\text { os territórios que tenham interesse em } \\
\text { participar e ter uma estimativa da demanda } \\
\text { para o sistema. }\end{array}$ & $\begin{array}{l}\text { Ação operacional. Disposto na FASE 1d, } \\
\text { sobre a demanda e o local do sistema. }\end{array}$ \\
\hline $\begin{array}{l}\text { 20. Passo: Chamada Pública para definir o } \\
\text { capital social do sistema, a governança } \\
\text { local ou a unidade executora local do } \\
\text { sistema. }\end{array}$ & $\begin{array}{l}\text { Ação operacional. Disposto na Fase } 3^{\mathrm{a}} \text { - } \\
\text { ENTRADAS, sobre o capital social do } \\
\text { sistema. }\end{array}$ \\
\hline $\begin{array}{l}\text { 3o passo: Investigação no CATMAT - } \\
\text { Sistema de Catalogação de Material se há } \\
\text { qualquer cadastro de produtos sustentáveis } \\
\text { que estejam de acordo em atender a } \\
\text { demanda apresentada pela chamada } \\
\text { pública. }\end{array}$ & $\begin{array}{l}\text { Ação de verificação atende uma pressão } \\
\text { da Empresa focal (Suerig e Muller, 2008). } \\
\text { Fase } 3 c \text { - ENTRADAS, sobre a gestão da } \\
\text { cadeia de suprimentos do sistema de } \\
\text { produção. }\end{array}$ \\
\hline $\begin{array}{l}\text { 4. Passo: chamada pública para formação } \\
\text { de grupos produtivos para o } \\
\text { desenvolvimento cooperativo de inovações } \\
\text { tecnológicas para produto e processo, } \\
\text { levando em consideração o método de } \\
\text { design para produto sustentável, bem como } \\
\text { demais induções contidas no Edital de } \\
\text { Chamada Pública, propostos pela Empresa } \\
\text { focal; }\end{array}$ & $\begin{array}{l}\text { Ação estratégica de planejamento do } \\
\text { sistema. Atende as características } \\
\text { principais: } 1^{\mathrm{a}} \text { (medida assistencial } \\
\text { governamental), } 2^{\mathrm{a}} \text { (contribuir com o } \\
\text { desenvolvimento local) e a } 3^{\mathrm{a}} \\
\text { (desenvolvimento cooperativo para } \\
\text { inovação tecnológica). Deve atender o } \\
\text { disposto nos itens da FASE } 3 \text { - } \\
\text { ENTRADAS DO SISTEMA: 3a sobre o } \\
\text { capital social; 3b sobre a mão de obra; } 3 \mathrm{c} \\
\text { sobre a gestão da cadeia de suprimentos; } \\
\text { os itens da } 3^{\mathrm{a}} \text {. FASE - } \\
\text { TRANSFORMAÇÃO: } 3 \mathrm{~d} \text { métodos em } \\
\text { design para projeto de produto } \\
\text { sustentável. }\end{array}$ \\
\hline $\begin{array}{l}\text { 5. Passo: Apresentação dos protótipos de } \\
\text { componentes e produto final, bem como a } \\
\text { descrição do ciclo de vida de ambos, } \\
\text { considerando as matrizes propostas como } \\
\text { protocolo de avaliação tanto para projeto } \\
\text { de produto como para avaliação da } \\
\text { cadeia de suprimentos e processos de } \\
\text { fabricação. }\end{array}$ & $\begin{array}{l}\text { Ação de Verificação. Deve atender aos } \\
\text { protocolos de avaliação de produtos } \\
\text { sustentáveis pela matriz que considera os } \\
\text { impactos dos recursos que serão } \\
\text { utilizados no sistema de fabricação em } \\
\text { todo ciclo do produto, desde a extração } \\
\text { da matéria-prima ate o seu pós-uso, } \\
\text { denominada de Matriz SQC - } \\
\text { Sustentabilidade, Qualidade e Custo. }\end{array}$ \\
\hline \multicolumn{2}{|c|}{$\begin{array}{l}\text { Continuação próxima página...(Figura } 17 \text { - Passos para implementação do } \\
\text { sistema no local pela empresa focal.) }\end{array}$} \\
\hline
\end{tabular}




\begin{tabular}{|c|c|}
\hline $\begin{array}{l}\text { Sequencia de passos para } \\
\text { funcionamento do sistema tendo como } \\
\text { base os instrumentos da administração } \\
\text { pública }\end{array}$ & $\begin{array}{l}\text { Relação dos passos com as } \\
\text { considerações apresentadas pelo } \\
\text { desenvolvimento do sistema }\end{array}$ \\
\hline $\begin{array}{l}\text { 60. Passo: Testes e ensaios de verificação } \\
\text { das especificações técnicas contidas no } \\
\text { edital por laboratórios credenciados pelo } \\
\text { INMETRO. }\end{array}$ & $\begin{array}{l}\text { Ação de verificação. Deve atender as } \\
\text { exigências da administração pública } \\
\text { para compras sustentáveis, disposto na } \\
\text { Fase 3c, sobre o modelo para gestão da } \\
\text { cadeia de suprimentos: sobre a } \\
\text { avaliação de fornecedores para riscos e } \\
\text { desempenho. }\end{array}$ \\
\hline $\begin{array}{l}7^{\circ} \text {. Passo: Divulgação dos grupos } \\
\text { produtivos definidos para fabricação de } \\
\text { insumos, fabricação do produto, } \\
\text { distribuição gratuita (casos de urgência) e } \\
\text { venda por comércio justo (quando a } \\
\text { urgência findar-se), manutenção do produto } \\
\text { durante o uso (caso seja o caso), take back } \\
\text { e reciclagem. }\end{array}$ & $\begin{array}{l}\text { Atende as características principais } 2^{\mathrm{a}} \\
\text { (contribuir com o desenvolvimento local) } \\
\text { e a } 3^{\mathrm{a}} \text { (desenvolvimento cooperativo } \\
\text { para inovação tecnológica). }\end{array}$ \\
\hline $\begin{array}{l}\text { 80 Passo: Publicação de edital a chamada } \\
\text { pública para compra de insumos e } \\
\text { contratação de serviços a fabricação e } \\
\text { logística de entrega. }\end{array}$ & \\
\hline $\begin{array}{l}\text { 99. Passo: Publicação de edital para } \\
\text { chamada pública para contratação, a titulo } \\
\text { de responsabilidade compartilhada, } \\
\text { conforme o Art1o. e § } 10 \text { da LEI No } 12.305 \text {, } \\
\text { DE } 2 \text { DE AGOSTO DE } 2010 \text {, que Institui a } \\
\text { Política Nacional de Resíduos Sólidos. } \\
\S 10 \text { Estão sujeitas à observância desta } \\
\text { Lei as pessoas físicas ou jurídicas, de } \\
\text { direito público ou privado, responsáveis, } \\
\text { direta ou indiretamente, pela geração de } \\
\text { resíduos sólidos e as que desenvolvam } \\
\text { ações relacionadas à gestão integrada ou } \\
\text { ao gerenciamento de resíduos sólidos. }\end{array}$ & $\begin{array}{l}\text { Atender o objetivo geral desta tese que } \\
\text { é desenvolver um sistema de produção } \\
\text { para fabricação de produtos capazes de } \\
\text { suprir necessidades básicas comuns a } \\
\text { indivíduos de origens e culturas } \\
\text { diversas. }\end{array}$ \\
\hline $\begin{array}{l}\text { 10․ Passo: Programar a distribuição do } \\
\text { produto considerando que: há distribuição } \\
\text { gratuita (casos de urgência) e venda por } \\
\text { comércio justo (quando a urgência findar- } \\
\text { se), e que o mesmo grupo responsável } \\
\text { pela logística reversa, será o mesmo que } \\
\text { distribui o produto nas Unidades } \\
\text { Executoras locais, definidas pelo Capital } \\
\text { Social, em parceria, com membros da } \\
\text { comunidade. }\end{array}$ & $\begin{array}{l}\text { Atende as características principais } 2^{\mathrm{a}} \\
\text { (contribuir com o desenvolvimento local) } \\
\text { e a } 3^{\mathrm{a}} \text {. (desenvolvimento cooperativo } \\
\text { para inovação tecnológica). Como } \\
\text { disposto na Fase 1c. sobre UEx's. }\end{array}$ \\
\hline
\end{tabular}

Figura 17 - Passos para implementação do SPPD pela empresa focal. 


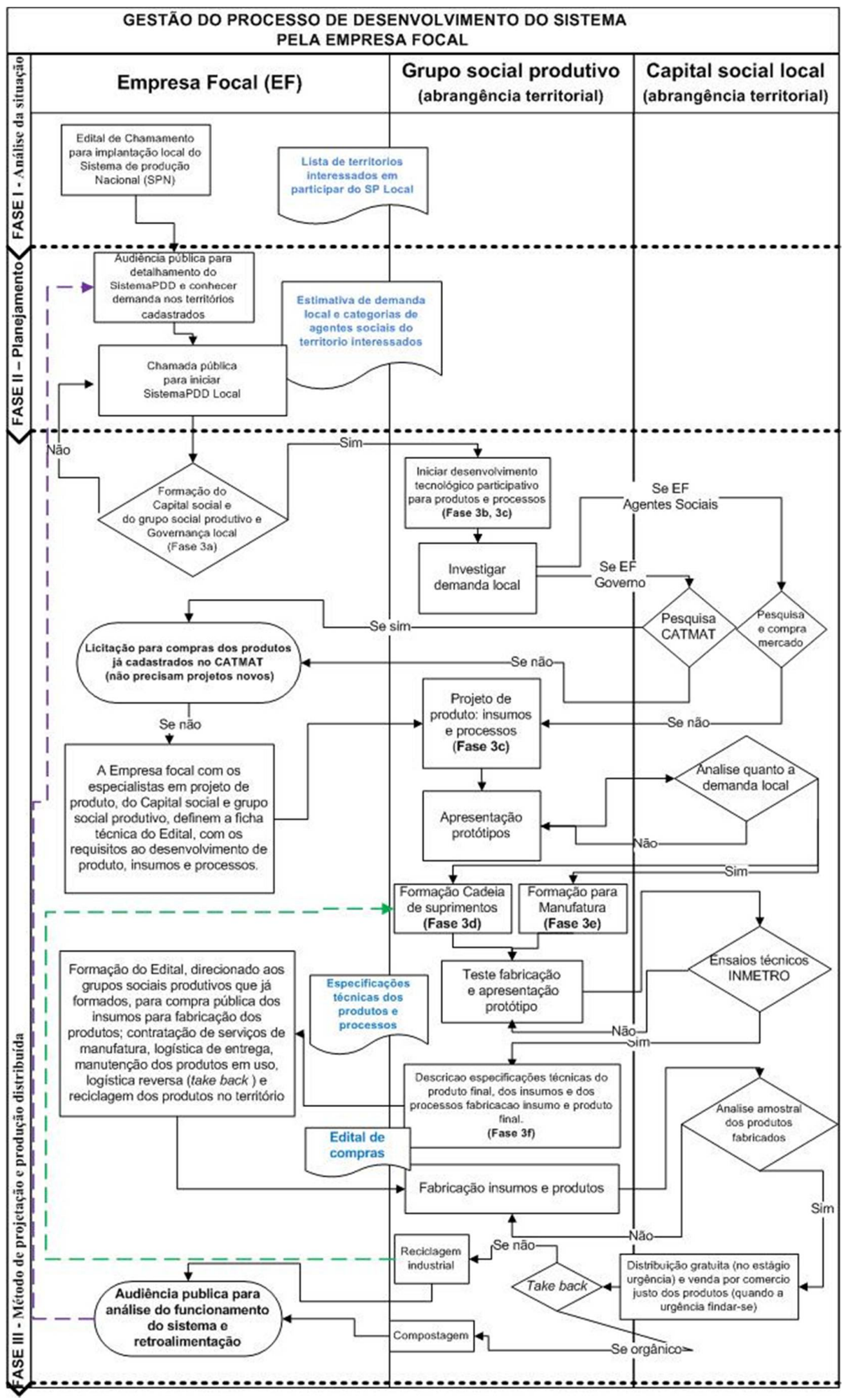

Figura 18 - Fluxograma dos passos para implementação do sistema. 


\section{3. \\ Método de projetação e produção distribuída: subsistemas de entrada, transformação, saída e retroalimentação (Fase 3)}

O subsistema de entrada compreende o capital social, a mão de obra e a gestão da cadeia de suprimentos. O subsistema de transformação compreende a projetação, o método de design e de produção. O subsistema de saída compreende a logística de distribuição e reversa.

\subsection{1.}

\section{Formação do capital social}

Capital social, segundo Albagli e Maciel (2002, p. 3), refere-se a um conjunto de instituições formais e informais, incluindo hábitos e normas sociais, que afetam os níveis de confiança, interação e aprendizado em um sistema social. Desta forma, a estrutura social tem a capacidade de mobilizar os agentes sociais para dar início ao trabalho participativo de desenvolvimento do sistema no local pretendido, como também legitimar e dar apoio, localmente, às atividades operacionais do sistema de produção. Segundo Santos (2000, p. 53), seria o mesmo que construir a integração solidária, obtida mediante solidariedades horizontais internas, para uma intervenção de transformação social.

Assim sendo, a formação do capital social, neste sistema, considerou os seguintes parâmetros:

os tipos de formação de agentes sociais formadores das experiências projetuais, analisadas no Capitulo II;

as propostas de rede de atores no formato de tríplice hélice público social (Senhoras, 2008, p. 141);

a perspectiva do design estratégico, considerando a estrutura das relações estratégicas para impulsionar a inovação tecnológica social (Capitulo II, figura 6).

as características estratégicas deste sistema: atender a população por direito e medida de assistência social governamental; motivar o desenvolvimento de inovações tecnológicas e contribuir com o desenvolvimento local.

Além de definir o capital social, é necessário definir os grupos sociais produtivos formados de acordo com a necessidade de desenvolvimento tecnológico de produtos e processos. Estes grupos devem representar a estrutura produtiva do sistema proposto, tanto para uma iniciativa governamental como para uma iniciativa por aglomerados de agentes sociais da sociedade civil 
(inclusive o governo), conforme figura 19. Esta proposta tem como base as reflexões teóricas, descritas no item 2.3, do Capitulo II, em que as ações estratégicas da inovação tecnológica social advêm das relações que se estabelecerão entre os agentes deste capital social local.

Isso se traduz em uma disposição ao envolvimento ativo e consciente nas relações estabelecidas e que assume a forma de aprendizagem, descoberta do outro como diferente de si. O papel do capital social é criar um sentido, um contexto, uma plataforma que seja válida para todos os sujeitos envolvidos na produção de valor. Ao constituir essa plataforma, constrói-se o sentido que irá apoiar a tomada de decisão estratégica de todos os atores de uma constelação de valores (Weick, 1995), porque apesar de existir uma polissemia de interesses individuais, todos compartilham um sentido de interesse comum ao pertencerem ao mesmo território.

Como exemplo, o capital social poderá ser composto por: 1) instituições governamentais, atuando como comprador e designando representantes para governança local (controle); 2) organizações não governamentais com capacidade para motivar o sistema no local; 3) fundações empresariais para apoiar as condições necessárias e possíveis quando da implantação do sistema nos territórios onde estão localizadas; 4) organizações empresariais para fabricação de insumos; 5) micro e pequenas empresas para fabricação de produtos e insumos; 6) trabalhadores artesanais (artesanato utilitário) para manufatura de produtos (Barroso Neto, 2011, p. 7); 7) fóruns locais de movimentos sociais, para motivar as atividades da comunidade; 8) instituições de ciência e tecnologia para apoiar o desenvolvimento de inovação tecnológica e; 9) comunidade local para contribuir, de forma participativa, com as atividades do sistema. Os APL's não foram citados porque, dentre os mencionados, todos têm capacidade para ser agente formador de um APL (Lastres e Cassiolato, 2003, p. 3 e 4; Paradizo, 2005, p. 40).

Esta formação é um diferencial diante as que foram identificadas nas experiências projetuais analisadas (Capitulo 2), porque considera um movimento de cooperação entre agentes e os modos de produção da sociedade local, este ultimo organizado pelo que foi denominado de grupo social produtivo do território, com uma formação que represente a estrutura produtiva para operacionalização do sistema no local ou virtual pelo conceito de Produção Distribuída (PD). Nas experiências projetuais analisadas, da mesma forma, não 
foi identificada qualquer formação de capital social por aglomerados produtivos, como os APL's, nem uma organização por PD.

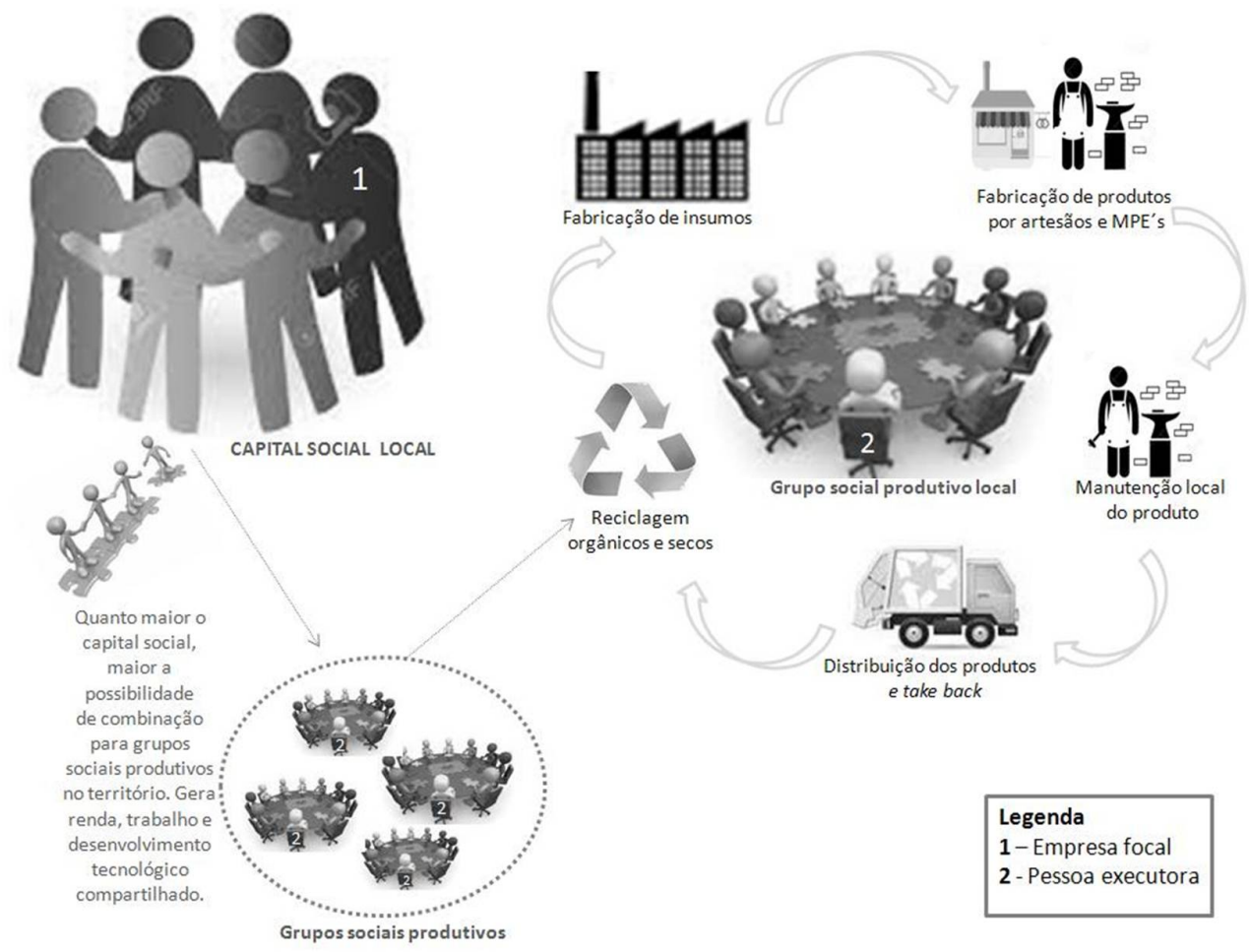

Figura 19 - Esquema demonstrativo da formação dos grupos sociais produtivos.

Esta proposta de formação de grupos sociais produtivos é a base conceitual do formato aberto do sistema, o que permite sua personalização às necessidades de cada território. O que também fortalece o seu caráter generalizado para fabricação de produtos diversos para necessidades básicas.

\subsubsection{1.}

\section{Participação dos APL's na formação do capital social}

Considerando a demanda deste sistema, que é nacional, e o grande número de pessoas com necessidades básicas não atendidas, nos territórios de cada região do Brasil, assumiu-se que os APL's seriam importantes para a formação do capital social. Na formação de seu capital social, os APL's já visam aglomerar "o quanto possível" os representantes da sociedade civil local como atores sociais, políticos e suas interações nos vários níveis de instâncias: Federal, Estadual e Municipal (Cassiolato e Matos, 2012, p. 192).

Assim, uma formação padrão para atender os propósitos deste sistema, deve prioritariamente firmar a governança local deste capital social que será o 
catalisador das relações entre os agentes no local em prol do interesse comum. Há categorias denominadas empresa focal ou hierárquica, quando uma das empresas é a que orienta a produção e as demais dependem dela, e as de governança associativa ou redes, quando o poder é distribuído entre os agentes sociais, exercendo o papel de coordenação das atividades econômicas e tecnológicas, com a presença de instituições, com regras coletivas e mecanismos de regulação (SEBRAE, 2010).

Segundo Paradizo (2005, p. 40), pelo grau de coesão e organização entre os agentes formadores do capital social, institui-se a infraestrutura produtiva dos APL's da qual participam: a) fornecedores de insumos específicos, componentes, máquinas e serviços; b) canais de distribuição e consumidores, o que envolve os fabricantes de produtos complementares e as empresas de setores industriais afins, podendo possuir semelhanças em tecnologias ou insumos comuns; c) instituições que forneçam treinamentos especializados em recursos humanos, informações em tempo hábil para o setor como um todo, fontes de pesquisa e suporte técnico; e d) instituições governamentais, de fomento, entidades ligadas ao setor empresarial, agentes que estejam envolvidos com a coordenação das ações e com políticas de apoio à inovação dos APL's para melhoria da competitividade e desenvolvimento tecnológico.

Tomando-se como referência a formação padrão de capital social de um APL, apresenta-se, na figura 20, uma formação de capital social considerando o tipo de iniciativa para a motivação e governança do sistema. A primeira alternativa é a governamental, como medida de Assistência Social e a segunda alternativa, por aglomerados de agentes representantes da sociedade civil (inclusive o Governo) de algum território a ser atendido para garantir o Direito ao atendimento não como filantropia ou assistencialismo. Ambas não são empresas fabricantes de produtos e, sim, contratantes, componentes do capital social, com o papel de gestores do sistema de produção para manufatura dos produtos, significando que em cada local ou território deverá ser definida uma unidade executora (UEx) que os represente. 


\begin{tabular}{|l|l|}
\hline $\begin{array}{l}\text { Tipo de } \\
\text { iniciativa }\end{array}$ & Agentes sociais sob a formação de um APL \\
\hline $\begin{array}{l}\text { 1a. Opção } \\
\text { Governamental } \\
\text { (Medida de } \\
\begin{array}{l}\text { Assistência } \\
\text { Social) }\end{array}\end{array}$ & $\begin{array}{l}\text { Instituições governamentais como comprador e governança local, em } \\
\text { cooperação com as governanças de cada APL capacitados à } \\
\text { formação da infraestrutura produtiva Do sistema: os APL's de setores } \\
\text { produtivos para fabricar produtos e fornecer insumos; e os APL's da } \\
\text { economia criativa (artesãos) para fabricar produtos e fornecer } \\
\text { insumos. A participação efetiva de instituições de ciência e tecnologia } \\
\text { à inovação. E fóruns de movimentos sociais locais. }\end{array}$ \\
\hline $\begin{array}{l}\text { 2a. Opção } \\
\text { Aglomerados de } \\
\text { representantes } \\
\text { da sociedade } \\
\text { civil (e Governo) }\end{array}$ & $\begin{array}{l}\text { ONGS ou Fóruns de movimentos sociais locais cooperando com as } \\
\text { Governanças de cada APL capacitados à formação da infraestrutura } \\
\text { produtiva, perfazendo um capital social formado ao máximo por } \\
\text { aglomerado de agentes sociais, representantes da sociedade civil, } \\
\text { como fundações empresariais, e o Governo a garantir o Direito. }\end{array}$ \\
\hline
\end{tabular}

Figura 20 - Configuração do capital social do sistema pela formação de um Arranjo Produtivo Local (APL).

A formação por aglomerados produtivos contribui quando o governo ( $1^{\text {a }}$. opção) ou os aglomerados de agentes representantes da sociedade civil (2a . opção) geram demanda e motivam o interesse dos APL's em participar como vetor operacional dos subsistemas de entrada, transformação, saída e retroalimentação do sistema de produção, porque a) têm estrutura para formar os grupos sociais produtivos, disponibilizando mão de obra para fabricação dos produtos, por meio dos profissionais agrupados por setores produtivos, como da economia criativa (artesãos) ou de micro e pequenas empresas; na formação da cadeia de suprimentos; b) podem promover o desenvolvimento cooperativo de inovações tecnológicas por ter em sua formação a participação de instituições de ciência e tecnologia e c) principalmente, porque este instrumento está presente em todos os estados do Brasil, o que atende a demanda nacional de distribuição destes produtos de atenção básica.

O sistema ora proposto se diferencia dos tradicionais modelos de cooperação em APL's porque sua demanda foca no atendimento às populações com necessidades básicas que não têm poder de compra, portanto suas estratégias não são destinadas à competitividade de mercado. Entretanto, dentre os setores produtivos constituintes dos APL's do Brasil (OBAPL, 2014) 32 deles podem atender diretamente necessidades básicas da população, ou apoiar na formação dos grupos sociais produtivos de cada território, como: alimentação, saúde, abrigo, vestuário, higiene e energia, conforme mostra a figura 21 . 


\begin{tabular}{|c|c|c|c|c|c|}
\hline \multicolumn{6}{|c|}{$\begin{array}{l}\text { SETORES PRODUTIVOS FORMADORES } \\
\text { DOS ARRANJOS PRODUTIVOS LOCAIS DO BRASIL } \\
\text { (*) Setores que atendem necessidades básicas diretamente = } 32 \\
\text { (Alimentação, saúde, abrigo, vestuário, higiene e energia). }\end{array}$} \\
\hline \multicolumn{2}{|c|}{ Setores produtivos } & \multicolumn{2}{|c|}{ Setores produtivos } & \multicolumn{2}{|c|}{ Setores produtivos } \\
\hline 1 & Aeroespacial & 20 & Economia Criativa* & 38 & Metal mecânico* \\
\hline 2 & Agricultura* & 21 & Eletroeletrônico* & 39 & Ovinocaprinocultura* \\
\hline 3 & Agricultura Orgânica* & 22 & Extrativismo Mineral & 40 & Pecuária* \\
\hline 4 & Agroindústria* & 23 & $\begin{array}{l}\text { Fabricação de alimentos } \\
\text { para animais }\end{array}$ & 41 & $\begin{array}{l}\text { Pesca, aquicultura e } \\
\text { serviços } \\
\text { relacionados* }^{*}\end{array}$ \\
\hline 5 & Alimentício* & 24 & Fabricação de bebidas & 42 & $\begin{array}{l}\text { Petróleo, Gás e } \\
\text { Naval. }\end{array}$ \\
\hline 6 & Alumínio & 25 & Fabricação de calçados * & 43 & Plástico \\
\hline 7 & Apicultura* & 26 & Fabricação de móveis* & 44 & $\begin{array}{l}\text { Prestação de } \\
\text { Serviços Ambientais }\end{array}$ \\
\hline 8 & Artesanato* $^{*}$ & 27 & Fármacos* & 45 & Produção Florestal \\
\hline 9 & Artigos Pirotécnicos & 28 & Fitoterápicos* & 46 & Produtos Químicos \\
\hline 10 & $\begin{array}{l}\text { Audiovisual, incluindo } \\
\text { jogos eletrônicos. }\end{array}$ & 29 & Floricultura* & 47 & Resíduos Sólidos \\
\hline 11 & Avicultura* & 30 & Fruticultura* & 48 & Rochas Ornamentais \\
\hline 12 & Bens de Capital & 31 & Gemas e Joias & 49 & Saúde* \\
\hline 13 & Biotecnologia* & 32 & Gesso* & 50 & $\begin{array}{l}\text { Serviços de } \\
\text { tecnologia da } \\
\text { informação }\end{array}$ \\
\hline 14 & Caprino cultura* & 33 & Horticultura* & 51 & Setor Gráfico \\
\hline 15 & Confecções $^{*}$ & 34 & Hortifrutigranjeiros $^{*}$ & 52 & Suinocultura* \\
\hline 16 & Construção Civil $^{*}$ & 35 & Laticínios* & 53 & Têxtil * \\
\hline 17 & $\begin{array}{l}\text { Construção e reparação } \\
\text { de embarcações }\end{array}$ & 36 & Logística & 54 & Têxtil e Confecções* \\
\hline 18 & Cosméticos* & 37 & Madeira a Aaricultura* & 55 & Turismo \\
\hline 19 & Defesa & U1 & 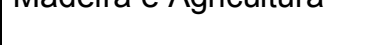 & 56 & Vitivinicultura \\
\hline
\end{tabular}

Figura 21 - Lista dos setores produtivos dos arranjos produtivos locais do Brasil (OBAPL, 2014).

Outra informação que se mostra a favor da produção utilizando os APL's como vetor para atendimento de necessidades, pode ser observado na Figura 22, quando apresenta o Estado do Pará como aquele que detém o maior número de APL's constituídos no Brasil. Entretanto, é o estado que possui o menor índice médio de desenvolvimento humano municipal (IDHM, 2010), o que vem fortalecer o argumento discutido pelos Objetivos de Desenvolvimento do Milênio (United Nations, 2015; Sachs, 2004, p. 14; 38) de que uma nação não pode ser considerada desenvolvida se apenas e considerado o fator econômico e não há 
investimentos em desenvolvimento humano, social e ambiental. Como afirma Vieira e Santos (2012, p. 19), a implantação de atividades industriais não assegura, isoladamente, a melhor distribuição da renda.

\begin{tabular}{|c|c|c|c|c|c|c|c|}
\hline \multicolumn{8}{|c|}{ Distribuição de APL's por estados com índice de IDHM } \\
\hline Estados & Pará & $\begin{array}{l}\text { Rio Grande } \\
\text { do Sul }\end{array}$ & São Paulo & $\begin{array}{l}\text { Minas } \\
\text { Gerais }\end{array}$ & Tocantins & Goiás & $\begin{array}{l}\text { Mato } \\
\text { Grosso do } \\
\text { Sul }\end{array}$ \\
\hline $\begin{array}{l}N^{\circ} \text {. de } \\
\text { APL's }\end{array}$ & 376 & 370 & 305 & 242 & 229 & 216 & 212 \\
\hline IDHM & 0,646 & 0,746 & 0,783 & 0,731 & 0,699 & 0,735 & 0,729 \\
\hline Estados & $\begin{array}{l}\text { Espírito } \\
\text { Santo }\end{array}$ & Alagoas & Bahia & $\begin{array}{l}\text { Mato } \\
\text { Grosso }\end{array}$ & Sergipe & $\begin{array}{l}\text { Rio } \\
\text { Grande } \\
\text { do Norte }\end{array}$ & Piauí \\
\hline $\begin{array}{l}N^{\circ} \text {.de } \\
\text { APL's }\end{array}$ & 170 & 158 & 157 & 152 & 131 & 130 & 120 \\
\hline IDHM & 0,74 & 0,631 & 0,66 & 0,725 & 0,665 & 0,684 & 0,646 \\
\hline Estados & Paraíba & Pernambuco & Maranhão & Rondônia & $\begin{array}{l}\text { Santa } \\
\text { Catarina }\end{array}$ & Acre & Amazonas \\
\hline $\begin{array}{l}N^{\circ} \text {. de } \\
\text { APL's }\end{array}$ & 112 & 98 & 96 & 91 & 90 & 80 & 74 \\
\hline IDHM & 0,658 & 0,673 & 0,639 & 0,69 & 0,774 & 0,663 & 0,708 \\
\hline Estados & $\begin{array}{l}\text { Rio de } \\
\text { Janeiro }\end{array}$ & Roraima & Paraná & Amapá & Ceará & Distrito fe & deral \\
\hline $\begin{array}{l}N^{\circ} \text {.de } \\
\text { APL's }\end{array}$ & 74 & 71 & 57 & 47 & 42 & 9 & \\
\hline IDHM & 0,761 & 0,707 & 0,749 & 0,674 & 0,682 & 0,792 & \\
\hline
\end{tabular}

Figura 22 - Número de APL’s por índices de IDH Estaduais

De acordo com as experiências do Instituto de Tecnologia Social (2011), a condição imprescindível para o desenvolvimento local é a definição do capital social, ou seja, do grau de confiança, organização social, participação cidadã e política, associação, mobilização e articulação entre pessoas, setores produtivos e grupos sociais.

\subsection{2.}

\section{Mão de obra}

Os APL's do Brasil podem ser a principal fonte para definir a mão de obra que estará participando do sistema, porque apresentam uma formação que contempla a aglomeração de empresas e artesãos locais, em comunhão com os propósitos do sistema, mas não exclui a participação do trabalho dos demais artesãos, cooperativas e empresas não vinculadas aos APL's pertencentes ao território. O propósito é que sejam valorizadas as habilidades das pessoas do local, gerando trabalho e renda de forma responsável, conforme as orientações dispostas 
nas Normas Regulamentadoras do Trabalho (NR's) do Ministério do Trabalho (MT), e dentro das capacidades e limites de cada pessoa (em se tratando de artesãos) de acordo com a atividade que será realizada em cada etapa do ciclo de vida do produto: no processo de extração da matéria-prima, na transformação da matéria-prima em componentes industriais (cadeia de suprimentos), na manufatura dos produtos, na manutenção dos produtos possíveis durante o uso (ampliando tempo de vida), no take back do produto e no processo de reciclagem dos resíduos não compostáveis.

Os APL's estão organizados por setores produtivos, e cada setor com seus segmentos. Assim, são interessantes para a formação de grupos sociais produtivos em oferta de mão de obra ou serviço: os APLs industriais para fornecimento de insumos industriais e manufatura de produtos que não possam ser manufaturados por grupos de artesãos locais; os APL's de artesanato, organizado por trabalhadores artesãos do utilitário ; e os APL's da economia criativa, nos seus segmentos de Arquitetura, Biotecnologia, Design, Moda e Pesquisa \& Desenvolvimento (FIRJAN, 2014).

Outra opção de mão de obra, além das pessoas já oficialmente vinculadas às empresas dos APL's, são os artesãos dos APL's do artesanato e os artesãos do utilitário que ainda não foram cadastrados no banco de APL's do artesanato (ou que queiram se manter sem cadastro).

Dentre os APL's citados, os de artesanato com grupos de trabalhadores artesãos locais oferecem a oportunidade de serem incluídos como mão de obra para a manufatura, com processos capazes de incorporar um conjunto de maneira que o artesão se utiliza ${ }^{23}$. Como descreve Martins (1973), o artesão é a pessoa que faz à mão objetos de uso frequente na comunidade, tendo surgido do resultado, entre a pressão da necessidade sobre a inteligência, aliada ao poder de inovar. Isto justifica considerar o artesão como mão de obra para um sistema que tem propósitos de atender populações carentes de oportunidades a um modo de vida sustentável. Importante esclarecer, no entanto, que o sistema proposto não tem qualquer intenção de promover ou motivar intervenção no trabalho de qualquer modalidade de artesanato do local, mas sim, conforme o antropólogo Ricardo

${ }^{23}$ Artesanato é fonte de produção, é o conjunto de maneiras pelas quais a coisa é feita. E produto é a coisa resultante do artesanato (Martins, 1973). 
Lima (Vidigal, 2003) explica sobre experiências com seu trabalho junto a programas de apoio ao artesanato:

Com o SEBRAE do Pará, por exemplo, temos mantido um diálogo muito intenso no sentido de respeitar e entender o artesanato local, a fim de que os profissionais se coloquem diante das comunidades muito mais para discutir o artesanato, do que para introduzir valores e modelos. Entretanto, com frequência, ainda nos deparamos com designers que acreditam deter o gosto, o padrão, o correto e o bonito. Sou contrário a atitudes impositivas. Acho que esses profissionais devem trocar informações com os artesãos e interagir com as comunidades, sem jamais descaracterizar as produções originais e seu lastro cultural.

É neste sentido que o sistema pretende considerar a inclusão dos artesãos do utilitário (Barroso Neto, 2011, p. 5; Martins, 1973) como alternativa de mão de obra do sistema, com o propósito de ofertar insumos, habilidades e conhecimentos para a manufatura e, especialmente, no prolongamento da vida útil do produto com a possibilidade de efetuarem a manutenção durante a fase de uso.

Para se ter uma estimativa das finalidades do artesanato, foi realizada uma pesquisa dos artesãos cadastrados no banco de dados dos APL's do Brasil, A análise dos dados identificou que:

- há diferença entre as atividades dos artesãos credenciados, sendo que existem trabalhos orientados a produzir objetos de função lúdica, decorativa e religiosa.

- há modalidades de artesanato: a) conceitual, que é a atividade principal de quem o produz, de relevante valor cultural; b) manual, descrito por Barroso Neto (2011, p. 4) como uma das fronteiras mais tênues com o artesanato conceitual, pois se apresentam como uma ocupação secundária, quando pessoas utilizam-se do tempo disponível ou ocioso para complementar a renda familiar. Os produtos geralmente são: roupas de bebê, toalhas, colchas, almofadas com aplicações de rendas e bordados, crochê, tapetes, cestos, caixas e uma infinidade de pequenos objetos para o lar ou de uso pessoal como acessórios e bijuteria, produtos que também foram identificados nos resultados da investigação quanto aos dos projetos brasileiros analisados no Capitulo II.

A análise dos dados não identificou os artesãos do utilitário, os quais Barroso Neto (2011, p. 5) descreve como sendo os artesãos de utensílios desenvolvidos para suprir carências e necessidades das populações de menor poder aquisitivo. São detentores de técnicas tradicionais elementares, de que o 
homem sempre se serviu para sua subsistência, voltados ao: vestuário (os alfaiates, as costureiras e os sapateiros); construção de casas e mobiliários (os pedreiros e os marceneiros); alimentação (os pescadores e agricultores familiares); cuidado com a saúde e higiene (cultivadores de ervas medicinais, raizeiros, benzedeiros, erveiros, curandeiros, parteiras, práticas dos terreiros de matriz africana e das comunidades indígenas e atividades terapêuticas, como florais e massagens, a homeopatia, a fito terapia e fabricantes de sabão) (Ministério da Saúde, 2012) e demais outros relacionados à manifestação cultural e necessidade de cada território.

Também não foi identificado que os produtos estejam sendo produzidos para suprir necessidades da própria comunidade, mas que estão sendo produzidos diretamente para venda em mercados tradicionais, conforme foi identificado na análise dos projetos brasileiros realizada no Capitulo II.

Em conclusão, a proposta de valorização do artesanato utilitário territorial assemelha-se ao que o Ministério da Saúde (2012, p. 10) cita sobre o papel da Educação Popular em Saúde que construiu sua singularidade não se contrapondo ou tentando sobrepor o saber científico, mas sim, agindo de forma compartilhada com as práticas profissionais de saúde instituídas no SUS (Sistema Único de Saúde).

Assim, percebe-se que é possível considerar o artesão do utilitário como fonte de mão de obra para o sistema, porque desta forma:

- estaremos não só reincorporando estes profissionais de valor cultural e simbólico ao território no modo de produção contemporâneo;

- estarão incentivando um comportamento de consumo consciente na comunidade, a partir de seu trabalho de manutenção do produto durante o uso, que prolonga o ciclo de vida do produto e evita a fabricação de novos, geração de resíduos e uso de recursos ambientais.

A modalidade de artesanato utilitário não foi identificada no cadastro de APL's do artesanato (OBPL, 2014), mas há a possibilidade de formação deste grupo produtivo em todo território nacional, com apoio de instituições governamentais regionais, conforme proposição do Ministério da Cultura que busca programar e consolidar políticas norteadas pelo Plano Nacional de Cultura (PNC), aprovado pela Lei 12.342 de 03/12/2010 e que prevê, entre suas 
estratégias, a ampliação da participação da cultura no desenvolvimento socioeconômico sustentável.

Importante consideração deve ser feita quanto à questão de gênero, pois a presença das mulheres é constante, em números representativos, como formadoras de capital social em projetos focados no desenvolvimento local ou de atenção à subsistência de famílias. Esta informação foi coletada durante a $22^{\mathrm{a}}$. Feira Internacional de Cooperativismo da Cidade Santa Maria, no Estado do Rio Grande do Sul, quando a pesquisadora participou da oficina sobre Fundos Rotativos Solidários, e foram ouvidos relatos, sobre a atividade feminina, de quatro empreendimentos solidários: o Grupo feminino Unidos Vivendo em Ação (MT); Centro de Agricultores familiares de Turmalina (MG), Grupo MANGA (Cariri / CE); Rede UVA (RS). O consenso apresentado pelos relatos foi que existem mulheres que não mais querem viver situações de opressão e violência doméstica, e outras estão reagindo a uma exclusão do mercado de trabalho formal porque possuem responsabilidades como mãe, atreladas a ausência de especialização profissional. Pelo reconhecimento destes pontos em comum, e ainda, pela busca do trabalho e renda, tornam-se solidárias entre si, criando o fortalecimento da dignidade, que é a força motriz e caracterização da formação dos empreendimentos solidários das mulheres.

Em conclusão, o capital social dos APL's tem capacidade para definir grupos sociais produtivos, com o fornecimento de mão de obra ao sistema.

\subsection{3.}

\section{Cadeia de suprimentos do sistema de produção}

O setor público está entre os grandes consumidores do mercado, gastando cerca de 10 a $15 \%$ do PIB para efetuar compras públicas. O sistema de produção, ao atender uma demanda nacional de produtos de necessidade básica, também se apresenta como um consumidor em grande escala de insumos e serviços. Nesse contexto, de acordo com Seuring e Müller (2008b, p. 1699), o governo ou o aglomerado de agentes sociais desempenham o papel de uma empresa focal, entendida como aquela que estabelece regras ou gerencia a cadeia de suprimentos, mantendo contato direto com o consumidor, além de definir as especificações que irão parametrizar os requisitos no método de design para desenvolvimento do projeto de produto ou insumo que a cadeia oferece. 


\section{Para manter a transparência pública nos procedimentos de formação} da cadeia de suprimento, tanto o governo como o grupo de agentes sociais poderão seguir orientações dos instrumentos usados pela administração pública. Portanto a descrição da formação da cadeia de suprimentos vai priorizar apresentar o funcionamento de instrumentos referenciados na gestão da administração pública.

A atividade da cadeia de suprimentos apresenta desafios, porque os seus impactos ambientais e sociais, a partir de seus processos e efluentes, acompanham a progressão de fabricação de insumos, salvo se estes vetores estiverem incorporados por protocolos de verificação, controle e responsabilidade compartilhada entre os agentes do modelo de gestão como pre-requisito para a formação da cadeia de suprimentos. Este comportamento orientado por práticas sustentáveis, difere daqueles processos licitatórios de compra pública exercida pelo Governo, ou por qualquer processo de avaliação para fornecimento de insumos, quando os parâmetros de decisão seguem a escolha pelo menor preço.

Carvalho (2011) ressalta que uma cadeia de suprimentos interessada em considerar dimensões ambientais e sociais, como os propostos para a cadeia deste sistema, deve ser orientada à sustentabilidade, tendo a empresa focal, o papel de induzir práticas socioambientais junto a fornecedores diretos e indiretos. Mesmo assim, diz o autor, para que a sustentabilidade torne-se integrada à organização desta cadeia, será preciso que a empresa focal tenha a gestão da cadeia de suprimentos orientada por meio de metas que o desempenho, social e ambiental, esteja atrelado à capacidade de inovação, e ao mesmo tempo sejam fatores prioritários.

O sistema proposto se enquadra nesta condição, porque se referencia em instrumentos específicos da administração publica para orientar a empresa focal, obedecendo três principais características que atendem a esta exigência: responsabilidade governamental em operacionalizar um sistema para atender necessidades básicas de populações carentes; contribuir com o desenvolvimento local dos territórios a serem atendidos e; motivar a cooperação entre agentes sociais do capital social do sistema, para o desenvolvimento de inovações tecnológicas que satisfaçam as necessidades dos seus usuários.

A indução de práticas socioambientais junto a fornecedores se dá pela imposição de requisitos socioambientais aos seus fornecedores diretos e indiretos 
(Carvalho, 2011, p. 187). Em se tratando da administração pública, o modelo de gestão sempre estará defendendo o uso do poder de compra do Estado como instrumento de fomento ao desenvolvimento sustentável, seguindo os ditames contidos no Art. $3^{\circ}$ da lei 8.666/93, com a nova redação dada pela Lei 12.349/10, que determina:

Art. $3^{\circ}$ : A licitação destina-se a garantir a observância do princípio constitucional da isonomia, a seleção da proposta mais vantajosa para a administração e a promoção do desenvolvimento nacional sustentável, e será processada e julgada em estrita conformidade com os princípios básicos da legalidade, da impessoalidade, da moralidade, da igualdade, da publicidade, da probidade administrativa, da vinculação ao instrumento convocatório, do julgamento objetivo e dos que lhes são correlatos.

Segundo a Secretaria de Logística e Tecnologia da Informação - SLTI, do Ministério do Planejamento, Orçamento e Gestão (MPOG), do ano 2010 até o mês de março de 2012, 735 unidades de órgãos governamentais usuários do SIASG ComprasNet realizaram 1.490 licitações utilizando itens de material do Sistema de Catalogação de Material (CATMAT). Os dados e resultados estatísticos das compras governamentais com critério de sustentabilidade por órgãos que mais adquiriram em número de licitações podem ser visualizados na figura 23 .

\begin{tabular}{|l|l|l|}
\hline Órgão governamental & $\begin{array}{l}\text { Quantidade } \\
\text { de licitação }\end{array}$ & $\%$ \\
\hline Ministério da Educação & 621 & 42 \\
\hline Ministério da Defesa & 283 & 19 \\
\hline Ministério da Justiça & 78 & 5 \\
\hline Ministério da Agricultura, Pecuária e Abastecimento. & 65 & 4 \\
\hline Ministério da Fazenda & 60 & 4 \\
\hline Ministério da Saúde & 45 & 3 \\
\hline Ministério do Meio Ambiente & 38 & 3 \\
\hline Ministério do Trabalho e Emprego & 31 & 2 \\
\hline Ministério da Ciência e Tecnologia & 30 & 2 \\
\hline Outros & 239 & 16 \\
\hline Valor Total & 1490 & 100 \\
\hline
\end{tabular}

Figura 23 - Número de APL's por índices de IDH Estaduais

Já a lista dos materiais sustentáveis mais licitados, pelo Sistema de ComprasNet do Governo Federal do Brasil, pode ser visualizada na figura 24. É importante notar que apesar do grande número de pessoas com necessidade de produtos de atenção básica, não foram identificados, na lista, produtos com capacidade de atendimento de populações carentes, público-alvo deste sistema de 
produção. Isto é mais uma justificativa para o desenvolvimento deste trabalho de pesquisa.

\begin{tabular}{|l|l|}
\hline Descrição Material no Sistema Compras Net & $\%$ \\
\hline Cartucho de tinta para impressora, reciclado. & 41,5 \\
\hline Cartucho toner impressora, reciclado. & 23,9 \\
\hline Aparelho ar condicionado, com selo PROCEL. & 7,5 \\
\hline Papel A4, papel reciclado. & 6,2 \\
\hline Envelope, papel reciclado. & 3,5 \\
\hline Papel OFFSET reciclado & 2,1 \\
\hline Papel SULFITE, celulose reciclada. & 1,8 \\
\hline Papel A4, certificação FSC ou Conselho de manejo florestal. & 1,2 \\
\hline Papel pardo, reciclado. & 1,1 \\
\hline Impressora Laser, frente/verso. & 1.0 \\
\hline Outros & 10,2 \\
\hline
\end{tabular}

Figura 24 - Lista de materiais sustentáveis reconhecidos como "mais licitados" pelo sistema compras Net do Governo Federal do Brasil entre 2010 e 2012.

Pinheiro (2013) evidencia que a preservação do meio ambiente passou a figurar entre os objetivos das licitações para contratações públicas, o que permite à Administração pública exigir de seus contratados cuidados necessários para minimizar os impactos da atividade que serão desenvolvidas, o que, em síntese, transforma o Governo em um agente motivador fundamental para a difusão de inovações tecnológicas, considerando o seu poder de influenciar outros membros da cadeia a introduzirem práticas sustentáveis.

Neste modelo de gestão da cadeia de suprimentos, o governo e os aglomerados de agentes sociais não só atuam como empresa focal, mas como aqueles que também legislam prescrevendo as próprias exigências (ou pressões ${ }^{24}$ ), motivações ou decisões para a implementação das práticas sustentáveis através da capacidade de coordenar e liderar processos de integração. A figura 25 estará apresentando as experiências da administração pública (Governo) em motivar ou pressionar decisões às práticas sustentáveis.

24 Pressões - indução e implementação das práticas socioambientais por processos de decisão, motivações e exigências legais, reconhecidas por Suering e Muller (2008) pela palavra: pressões. 


\begin{tabular}{|c|c|c|}
\hline $\begin{array}{l}\text { Induções para implementação das } \\
\text { práticas socioambientais }\end{array}$ & Relação com o sistema & $\begin{array}{l}\text { Impactos } \\
\text { positivos ao } \\
\text { sistema }\end{array}$ \\
\hline \multicolumn{3}{|l|}{ Motivações } \\
\hline $\begin{array}{l}\text { Lei Complementar } N^{\circ} 123 / 2006, \\
\text { instituiu o Estatuto Nacional das } \\
\text { MPE's e estabeleceu normas gerais } \\
\text { ao tratamento diferenciado e } \\
\text { favorecido a ser dispensado às MPE’s } \\
\text { no âmbito dos Poderes da União, dos } \\
\text { Estados, do Distrito Federal e dos } \\
\text { Municípios. Nas contratações públicas } \\
\text { de bens, serviços e obras, no âmbito } \\
\text { da administração pública federal } \\
\text { regulamentado pelo Decreto } N^{\circ} 6.204 \text {, } \\
\text { de } 2007 \text {. }\end{array}$ & $\begin{array}{l}\text { A cadeia de suprimentos } \\
\text { do sistema de produção } \\
\text { será constituída pelas } \\
\text { micro e pequenas } \\
\text { empresas formadoras do } \\
\text { capital social dos Arranjos } \\
\text { Produtivos Locais e demais } \\
\text { outras que tiverem } \\
\text { interessem em participar da } \\
\text { chamada pública. }\end{array}$ & $\begin{array}{l}\text { Garantia de } \\
\text { participação no } \\
\text { processo de } \\
\text { compras públicas } \\
\text { para produtos de } \\
\text { atenção básica. }\end{array}$ \\
\hline \multicolumn{3}{|l|}{ Processos de decisão } \\
\hline $\begin{array}{l}\S 5^{\circ} \text { da Lei } \mathrm{N}^{\circ} 12.349 \text {, de } 2010 \text { que } \\
\text { permite aplicação da margem de } \\
\text { preferência de até } 25 \% \text { para produtos } \\
\text { manufaturados e serviços nacionais } \\
\text { que atendam a normas técnicas } \\
\text { brasileiras e incorporem inovação. }\end{array}$ & $\begin{array}{l}\text { Consta como uma das } \\
\text { características estratégicas } \\
\text { do sistema, o } \\
\text { desenvolvimento de } \\
\text { inovação tecnológica em } \\
\text { cooperação com agentes } \\
\text { sociais, em especial, } \\
\text { aqueles que irão compor a } \\
\text { cadeia de suprimentos. }\end{array}$ & $\begin{array}{l}\text { A garantia de } \\
\text { compra de } \\
\text { produtos } \\
\text { manufaturados } \\
\text { pelo sistema, em } \\
25 \% \text { do total } \\
\text { demandado pelas } \\
\text { compras públicas, } \\
\text { salvo se } \\
\text { estiverem de } \\
\text { acordo com as } \\
\text { especificações } \\
\text { exigidas em } \\
\text { edital. }\end{array}$ \\
\hline \multicolumn{3}{|l|}{ As pressões } \\
\hline $\begin{array}{l}\text { Lei } \mathbf{N}^{\circ} \mathbf{1 2 . 3 0 5} \text {, de } 2010 \text {, que } \\
\text { estabelece como objetivos a } \\
\text { prioridade, nas aquisições e } \\
\text { contratações governamentais, para } \\
\text { produtos reciclados e recicláveis e } \\
\text { para bens, serviços e obras que } \\
\text { considerem critérios compatíveis com } \\
\text { padrões de consumo social e } \\
\text { ambientalmente sustentáveis. }\end{array}$ & $\begin{array}{l}\text { Condição atendida pelas } \\
\text { características do sistema, } \\
\text { pelo método em design } \\
\text { para projeto de produto } \\
\text { (ecodesign) e modelo de } \\
\text { produção excluindo os } \\
\text { impactos no meio ambiente } \\
\text { e às pessoas (Braungart e } \\
\text { McDonough, 2002). }\end{array}$ & $\begin{array}{l}\text { Prioridade dos } \\
\text { produtos } \\
\text { manufaturados } \\
\text { pelo sistema nas } \\
\text { aquisições e } \\
\text { contratações } \\
\text { governamentais. }\end{array}$ \\
\hline
\end{tabular}

Figura 25 - Induções da empresa focal para implementação das práticas socioambientais.

Carvalho (2011) cita que pressões e incentivos para a adoção de práticas de sustentabilidade afetam a colaboração dos fornecedores, desde a obtenção de informações sobre aspectos sociais e ambientais da produção inicial da cadeia (extração de matéria-prima) até a busca por melhoria de desempenho dos principais fornecedores. No caso dos APL's, enquanto agentes formadores da cadeia de suprimentos do sistema, o desafio não é tão difícil de ultrapassar, pois naturalmente detém a rotina de manter algumas atividades estratégicas de 
otimização da produção por cooperação entre as habilidade e especializações de cada agente. Uma prática que oportuniza um ambiente favorável ao uso do sistema de produção distribuída (SPD).

No mercado tradicional, onde empresas lutam pela competitividade, estas dinâmicas visam o desenvolvimento de fornecedores parceiros e sua permanência como um fornecedor base. Isto, por um lado, otimiza os processos de inovação por práticas de descomoditização, transparência, rastreabilidade e certificação, mas por outro limita a entrada de novos fornecedores na cadeia, porque os processos de desenvolvimento de fornecedores são de longo prazo, para dar tempo as relações de confiança que se estabelecem entre eles. Como o sistema visa o desenvolvimento local pela igualdade de direitos, a formação da cadeia de suprimentos deverá priorizar, a cada necessidade de compra, a chamada pública de fornecedores interessados em desenvolver inovação tecnológica, em parceria, por formação de grupos que tenham interesse em apresentar soluções para a demanda apresentada: os grupos sociais produtivos. Para isso, deverão ser convidados fornecedores, nas diversas especialidades representativas a cada componente e processo capazes de manufaturar um produto.

Nesse sentido, os grupos que melhor forem avaliados diante as especificações técnicas contidas no Edital serão os fornecedores base para atender, especificamente, aquela chamada pública. É uma forma de dar oportunidade a todos os interessados e motivar inovações tecnológicas às necessidades do Brasil.

Para orientar a gestão de uma cadeia de suprimentos, podem ser analisados modelos divulgados pela literatura científica. Dos modelos estudados por Carvalho (2011), o que mais se ajusta ao que se pretende alcançar com o funcionamento desta cadeia é o de Seuring e Müller (2008b, p. 1705; 1706), que afirmam que apesar da cadeia de suprimentos sustentável exercer o papel de gestão dos fluxos de materiais, informações e capital, ela tem o papel de realizar a cooperação entre empresas para alcançar as três dimensões do desenvolvimento sustentável: econômica, ambiental e social, sem deixar de considerar as necessidades dos consumidores e das partes interessadas. Portanto, gera trabalho e renda, valoriza as pessoas ao seu entorno e não impacta o ecossistema.

O modelo proposto considera a empresa focal como objeto de pressões, para a indução e implementação de inovações socioambientais, exercendo um monitoramento para melhor avaliar os fornecedores diante os riscos e seus 
desempenhos, a partir de duas ações: por Avaliação de fornecedores para risco e desempenho (supplier management risk and perfomance - SMRP) e Gestão da cadeia de suprimento para produtos sustentáveis (supply chain management for sustainable products - SCMSP) (figura 26). Elas são abordagens baseadas nos atributos do ciclo de vida do produto, exigindo intensa cooperação junto a fornecedores diretos ou indiretos.

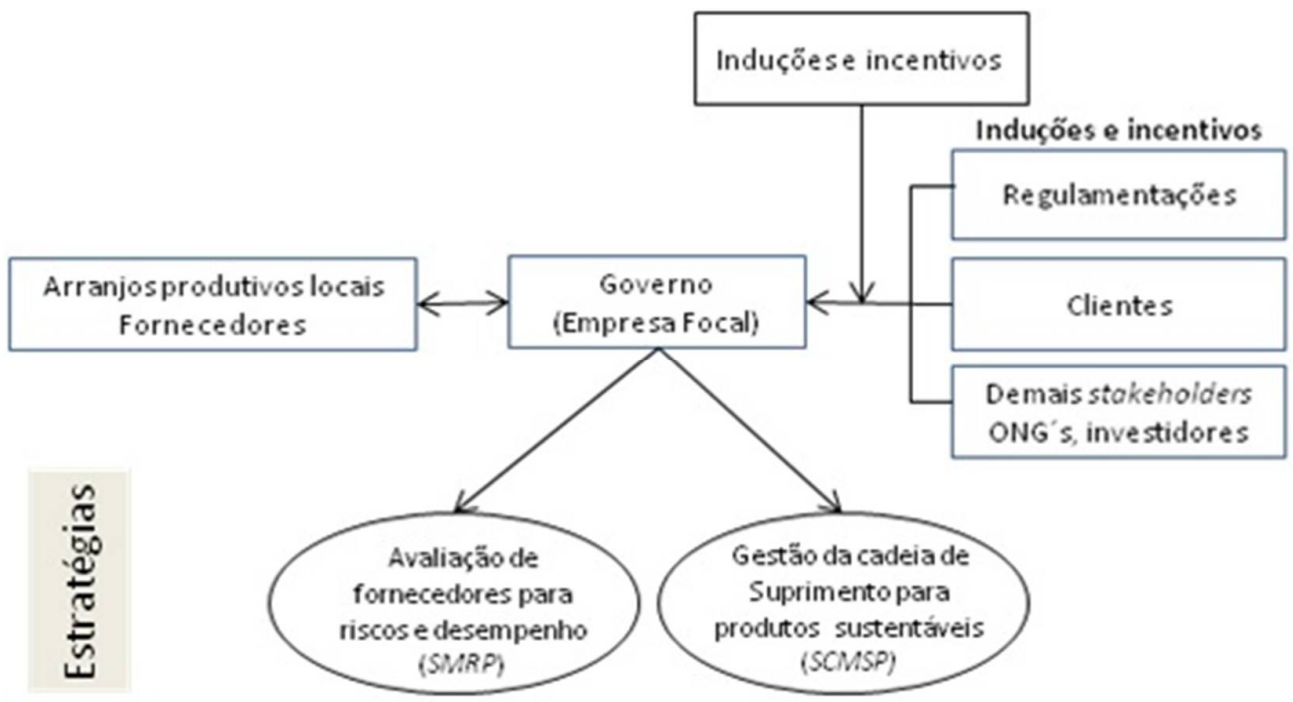

Figura 26 - Modelo para gestão da cadeia de suprimentos do sistema de produção, conforme Seuring e Muller (2008b, p. 1706).

De acordo com Seuring e Müller (2008b, p. 1706), o modelo da Figura 26 apresenta três aspectos que o distingue de uma cadeia de gestão de suprimentos tradicional (Supply Chain Managment):

1) exige examinar um número maior de impactos em uma cadeia de suprimento extendida em função da indução e incentivos, porque agrupa demais agentes sociais além dos fornecedores de insumos, como ONGS, comunidades e stakeholders;

2) considera um grupo mais numeroso de objetivos de desempenho pela incorporação das dimensões ambiental e social da sustentabilidade; e

3) exige a integração e cooperação entre membros da cadeia de suprimentos. As duas estratégias, a de Avaliação de fornecedores para riscos e desempenho e Gestão da cadeia de suprimento para produtos sustentáveis (SCMSP) não são excludentes, mas ambivalentes (Carvalho, 2011) apoiando a gestão da cadeia de suprimentos da empresa focal. 


\subsubsection{1. \\ Modelo para gestão da cadeia de suprimentos: avaliação de fornecedores para riscos e desempenho}

A empresa focal inicia e consolida um processo de incorporação de critérios sociais e ambientais para avaliação de fornecedores quanto a riscos e desempenho, conforme figura 27. Neste caso, a administração pública do Brasil possui mecanismo do Estado para operacionalizar a Lei, denominado de Agenda Ambiental da Administração Pública (A3P). A A3P visa implantar a responsabilidade socioambiental nas atividades administrativas e operacionais da administração pública, com base nos seguintes eixos temáticos: uso racional dos recursos naturais e bens públicos; gestão adequada dos resíduos gerados; qualidade de vida no ambiente de trabalho; sensibilização; e o ultimo eixo, diretamente relacionado ao assunto tratado, capacitação dos servidores para licitações sustentáveis.

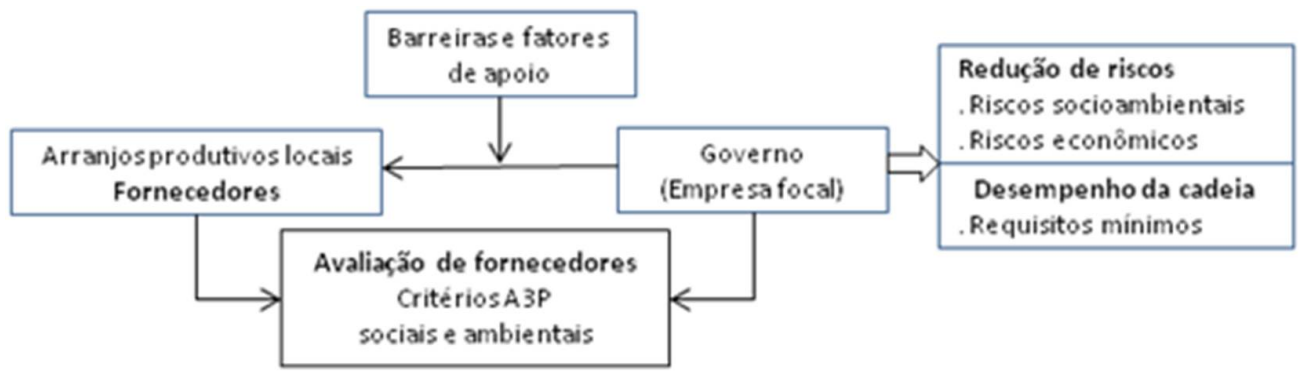

Figura 27 - Detalhamento da estratégia para avaliação de fornecedores para riscos e desempenho. Adaptado do Modelo de Seuring e Müller (2008b, p. 1706).

Este modelo de gestão da cadeia de suprimentos não estabelece um processo licitatório de compra de produtos prontos a serem usados, mas um instrumento diferenciado porque prima pela apresentação de soluções por grupos sociais de fornecedores, podendo iniciar por uma audiência pública, como forma de juntar os licitantes para receber suas opiniões ao certame que será proposto para avaliação na redução de riscos socioambientais e econômicos.

Os órgãos e entidades da Administração Pública Federal direta, autárquica e fundacional, quando da aquisição de bens, poderão exigir que sejam atendidos os seguintes critérios de sustentabilidade ambiental, segundo o Art. $5^{\circ}$, da Instrução Normativa $\mathrm{n}^{\mathrm{O}}$ 01, de 19 de janeiro de 2010 (MPOG, 2010): 
I - que os bens sejam constituídos, no todo ou em parte, por material reciclado, atóxico, biodegradável, conforme ABNT NBR - 15448-1 e 15448-2;

II - que sejam observados os requisitos ambientais para a obtenção de certificação do Instituto Nacional de Metrologia, Normalização e Qualidade Industrial - INMETRO como produtos sustentáveis ou de menor impacto ambiental em relação aos seus similares;

III - que os bens devam ser, preferencialmente, acondicionados em embalagem individual adequada, com o menor volume possível, que utilize materiais recicláveis, de forma a garantir a máxima proteção durante o transporte e o armazenamento;

IV - que os bens não contenham substâncias perigosas em concentração acima da recomendada na diretiva RoHS (Restriction of Certain Hazardous Substances), tais como mercúrio $(\mathrm{Hg})$, chumbo $(\mathrm{Pb})$, cromo hexavalente $(\mathrm{Cr}$ $(\mathrm{VI})$ ), cádmio (Cd), bifenil-polibromados (PBBs), éteres difenilpolibromados (PBDEs).

$\mathrm{O} \S 1^{\circ}$ permite que a comprovação das exigências seja realizada mediante apresentação de certificação emitida por instituição pública oficial, instituição credenciada ou por qualquer outro meio de prova que ateste que o bem fornecido cumpre com as exigências do edital.

Segundo a FGV (2012), definido o objeto a ser adquirido e os atributos de sustentabilidade, a organização poderá elaborar a especificação técnica do produto com ajuda de profissionais especializados. É previsto ainda, que as especificações sejam solicitadas não como caráter compulsório, porque vai depender da comparação entre a disponibilidade do produto no mercado e de componentes que atendam as especificações técnicas elaboradas pelos setores produtivos e divulgadas por instituições como a Associação Brasileira de Normas Técnicas (ABNT).

No setor público, a especificação deve levar em conta aspectos técnicos e jurídicos, atentando tanto para a garantia da competitividade, sem direcionar a contratação, quanto para as novas normas que tratam especificamente de sustentabilidade (FGV, 2012, p. 56 e 57):

- ambientais (usar protocolos de avaliação, reduzir material de embalagens, incentivar a concepção de produtos recicláveis ou reutilizáveis, considerar a toxicidade de materiais e produtos, matéria-prima renovável, eficiência energética, uso de água, redução de emissões de gases e desperdícios);

- diversidade (comprar de empresas pertencentes a mulheres e a minorias, como quilombolas e indígenas),

- segurança (garantir o transporte seguro de insumos e produtos, bem como que as instalações dos fornecedores sejam operadas com segurança); 
- direitos humanos (visitar instalações de fornecedores para garantir que não estejam usando trabalho análogo ao escravo, trabalho infantil e se estão pagando um salário digno) e;

- compras de pequenas empresas locais (comprar de micro e pequenas empresas e fornecedores locais).

Também podem ser consideradas as diretrizes apresentadas pelo Decreto 7. 746/10 (Arantes, 2014):

I - menor impacto sobre recursos naturais como flora, fauna, ar, solo e água; II - preferência para materiais, tecnologias e matérias-primas de origem local;

III - maior eficiência na utilização de recursos naturais como água e energia;

IV - maior geração de empregos, preferencialmente com mão de obra local;

$\mathrm{V}$ - maior vida útil e menor custo de manutenção do bem e da obra;

VI - uso de inovações que reduzam a pressão sobre recursos naturais; e

VII - origem ambientalmente regular dos recursos naturais utilizados nos bens, serviços e obras.

Os critérios de sustentabilidade podem ser comprovados por estudos técnicos e científicos; certificações ambientais; boas práticas nacionais e internacionais, de amplo conhecimento e domínio de mercado. Entretanto recomenda Arantes (2014): que a verificação dos critérios siga os mesmos procedimentos de verificação dos requisitos de desempenho e qualidade, salvo se as especificações técnicas forem divulgadas como não compulsórias.

\subsubsection{2. \\ Modelo para gestão da cadeia de suprimentos: a gestão da cadeia de suprimento para produtos sustentáveis}

Segundo o Ministério do Meio Ambiente (2015), deve-se atentar para eleger os bens e serviços cujas características atendam as especificações adequadas, tanto em termos de qualidade e funcionalidade, em conformidade com o dever do Estado de proteção ao meio ambiente, bem como quanto aos princípios e deveres do Estado definidos na Constituição Federal. Um modelo que pode ser utilizado, e que necessariamente deve ser a primeira atividade da gestão da cadeia de suprimentos, possui 5 passos, denominados fase interna:

$1^{\circ}$ - Identificar os bens, serviços e obras mais adquiridos para analisar a viabilidade de adotar exigências de sustentabilidade nas licitações futuras, optando por produtos equivalentes que causem menor impacto ambiental e, que, por exemplo, tenham maior eficiência energética. Também devem ser exigidas práticas sustentáveis nas execuções dos serviços e obras;

$2^{\circ}$ Verificar a disponibilidade no mercado e acessar o Portal de Compra do Governo Federal com Critérios de Sustentabilidade: CATMAT; 
$3^{\circ}$ Incluir gradativamente critérios ambientais, elaborando especificações técnicas claras e precisas dos produtos, bens e construções sustentáveis. $4^{\circ}$ Incluir novos critérios nos editais de compras, serviços e obras e $5^{\circ}$ Comunicar-se com outros gestores para trocar informações, pedir auxílio e sensibilizá-los.

Tendo realizado os procedimentos anteriores, segue-se então para a especificação de produtos sustentáveis que tem na avaliação de ciclo de vida (lifecycle analysis, LCA) uma ferramenta essencial para garantir que a empresa focal tome decisões mais acertadas (Seuring e Müller, 2008, p. 1706). Contudo, a ACV é uma ferramenta que demanda tempo para ser executada e não é a mais adequada para produtos de atendimento de necessidades básicas, especialmente nos estágios de urgência onde a tomada de decisão deve ser "o quanto mais breve for possível". Assim, propõe-se que seja utilizada, como protocolo de avaliação no lugar da ACV (Figura 28), uma Matriz que considera os impactos dos recursos que serão utilizados no sistema de fabricação em todo ciclo do produto, desde a extração da matéria-prima ate o seu pós-uso, denominada de Matriz SQC Sustentabilidade, Qualidade e Custo (Guimarães, 2010) (Anexo II).

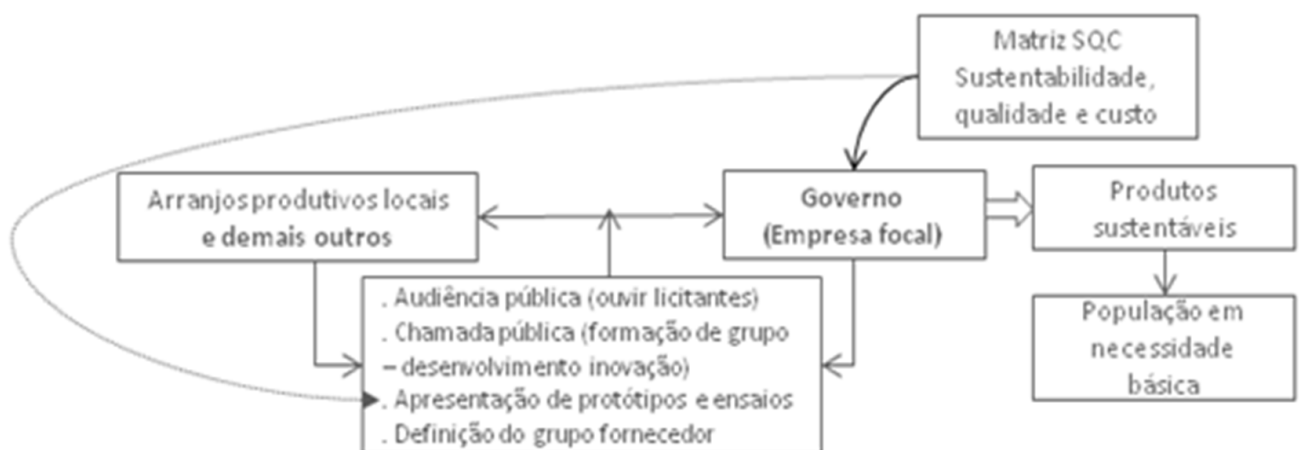

Figura 28 - Gestão da cadeia de suprimento para produtos sustentáveis

Esta Matriz, que compõe o $3^{\circ}$. Passo do método de design sociotécnico, proposto por Guimarães (2010, p. 4; 60), tem a função de estruturar os parâmetros conceituais de um projeto, meio ambiente, dos três usuários humanos que participam do ciclo de vida do produto (usuário primário: na extração e transformação/fabricação; usuário secundário: na logística; usuário terciário: o consumidor) e nos três ciclos do produto (processo, uso e logística de entrega reversa). A matriz realiza essa tarefa calculando as médias geométricas das colunas para os itens de sustentabilidade (nos três ciclos do produto - processo, uso e logística), qualidade e custo. Sua última coluna é de resultados finais, para 
cada um dos três itens, e a pontuação final é a média geométrica dos resultados finais dos três itens.

Precede o uso da Matriz SQC, a coleta de informações quanto a todas as matérias-primas, componentes (matéria-prima transformada) e processos usados na manufatura do produto, como também possíveis materiais alternativos como resíduos da logística reversa e reciclagem prevista na estrutura deste sistema. $\mathrm{O}$ preenchimento da matriz requer um grupo de especialistas para responder, que pode ser exercido pelo grupo social produtivo (inscritos na chamada pública) formado para desenvolver inovações no sistema.

Os temas abordados são relativos à origem da matéria-prima, seu processo de transformação e seu custo. Da mesma forma, a matriz deve ser preenchida para os componentes fabricados e seus processos, considerando a acessibilidade no mercado, o custo de aquisição, o custo de produção e a diversidade de uso de materiais na sua montagem.

Em conclusão, a cadeia de suprimentos do sistema deverá seguir o que o modelo de Suering e Muller (2008) indica como Avaliação de fornecedores para riscos e desempenho e Gestão da cadeia de suprimento para produtos sustentáveis (SCMSP) devendo ocorrer pelos 10 procedimentos a seguir:

1) formação do capital social da cadeia de suprimentos por APL's específicos ou demais outros agentes interessados;

2) cooperação para inovação tecnológica e definição das especificações de produto e processo do produto;

3) chamada para cadastro de fabricantes locais e unidades executoras locais (compra e distribuição aos consumidores finais);

4) cadastramento de responsáveis pelo take back;

5) cadastramento de empresas recicladoras locais;

6) recebimentos dos protótipos para análise das exigências em especificações técnicas conforme edital;

7) análise participativa entre todos os agentes sociais produtivos envolvidos na apresentação e definição dos protótipos;

8) chamada de fabricação e compra de insumos;

9) chamada de fabricação, compra e distribuição do produto; e.

10) chamada de take back e reciclagem dos resíduos. 


\subsection{4. Método em design para projeto de produtos}

Steve Jobs disse à BusinessWeek, em 1995: é difícil desenhar produtos por focus groups. Muitas vezes, as pessoas não sabem o que querem até você mostrar para elas. O público-alvo dos produtos a serem fabricados por este sistema provavelmente também não sabe o que quer, mas vivencia a ausência de produtos e serviços básicos para uma condição de vida digna. Neste sentido, esta proposta metodológica em design de produto tem como ponto de partida compreender "a situação" ou o estado das pessoas insatisfeitas, como um problema que precisam solucionar, não se fixando a analisar propostas de produtos já existentes, porque estes podem até auxiliar no atendimento ao estado de urgência, mas não serão capazes de aglutinar os requisitos definidos para que essas pessoas alcancem um estado sustentável de suas vidas ou bem viver, o que no sistema apontamos como o $2^{\circ}$. e $3^{\circ}$ estágio de vivência da situação (figura 15 ).

Tais contextos sociais fazem emergir, ao campo do design, o desafio de encontrar soluções por processos de inovação que tenham a sustentabilidade como meta, sem que as ações tornem-se filantrópicas ou assistencialistas. O desafio não é simples, devido a variabilidade de requisitos a serem atendidos em cada uma das dimensões da sustentabilidade: a social, a ambiental, a territorial, a econômica e a política (Sachs, 2004, p. 15).

Dois parâmetros são considerados na formatação das primeiras fases do método em design para mudança da situação vivida pelo público-alvo deste sistema:

O primeiro é compreender que a Empresa focal, quer seja o governo ou a segunda alternativa, os agentes sociais, não são empresas fabricantes de produtos e sim instituições contratantes, mas que detém o papel de gestores do sistema de produção para manufatura dos produtos que precisam distribuir ou subsidiar sua manufatura. Portanto, a equipe de projeto ou desenvolvimento da inovação tecnológica será representada pelo grupo social produtivo que será formado obedecendo ao que foi descrito na FASE 3: o capital social e mão de obra. Cabendo ressaltar a presença dos designers vinculados aos APL's da Economia Criativa ou aos grupos de inovação tecnológica pertencentes às Universidades ou Institutos Tecnológicos. 
O segundo parâmetro é compreender que apesar de priorizar o desenvolvimento de inovação em produtos e processos, os contextos sociais dos usuários com necessidades básicas não atendidas apresentam-se em três estágios: 1) o momento de urgência (indivíduos em situação de pobreza ou extrema pobreza), que necessitam atendimento imediato e não podem pagar pelo produto; 2) o de manutenção, ou de desenvolvimento contínuo para alcançar e se estabilizar na meta e; 3) de sustentabilidade, que engloba aqueles que saíram dos estágios anteriores e não devem jamais retornar ao estado inicial (figura 29).

Assim, dois tipos de produtos são elencados: aqueles que já existem e atendem aos usuários, e aqueles que precisam sofrer modificações incrementais, ou ser fruto de inovação, ambos para atender o momento imediato de urgência, até que atinja o segundo momento da situação - o de manutenção, que já estará em fase de implementação.

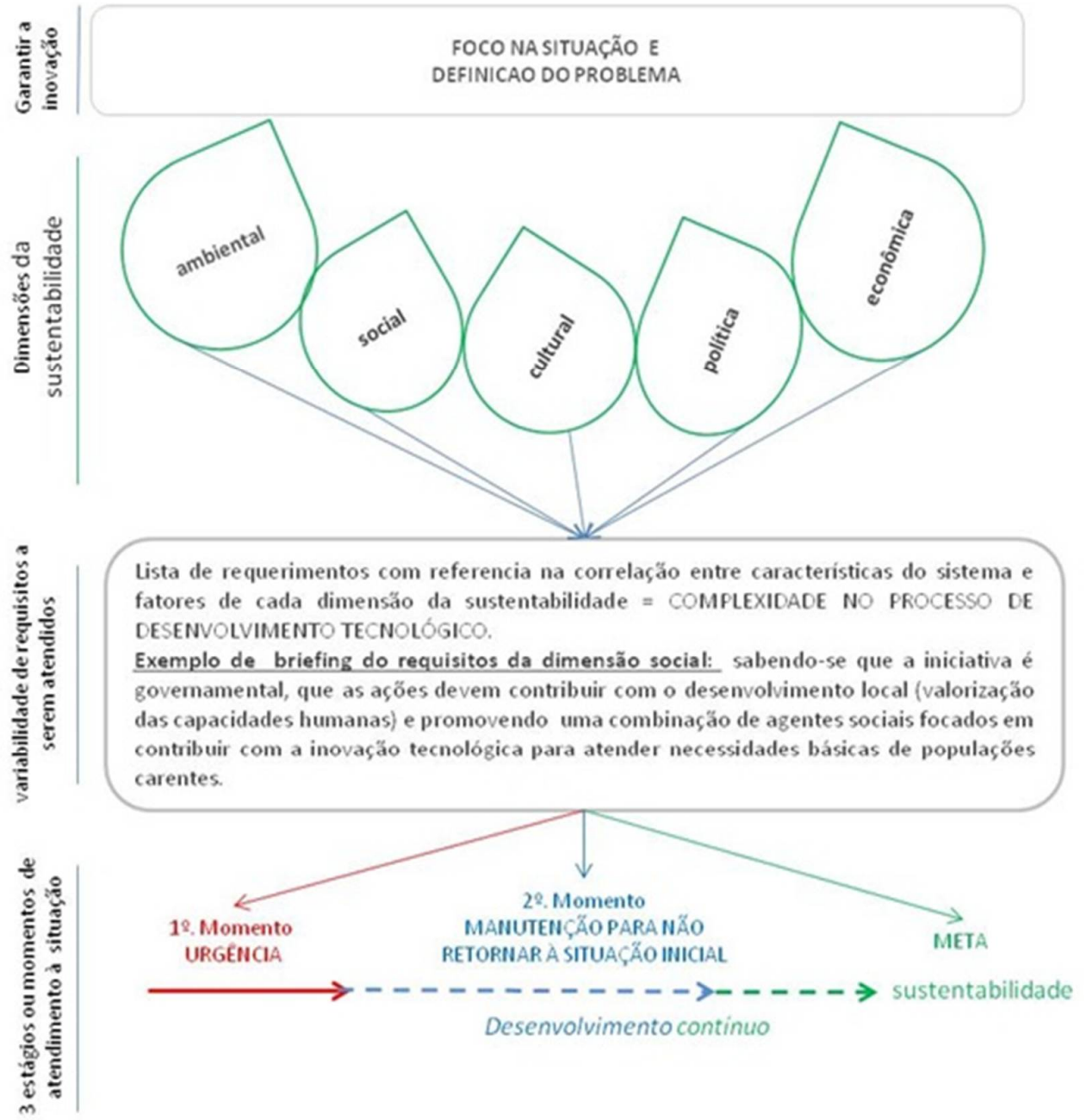

Figura 29 - Pensamento em design ao desenvolvimento projetual 
O método em design é proposto como um orientador do desenvolvimento do projeto de produtos a ser realizado pelo grupo social produtivo do sistema local, apesar de considerar a presença do designer. Ele não seguiu uma única proposta de projeto ou desenvolvimento de produtos ou serviços disponível na literatura, entretanto teve como parâmetro a necessidade da situação social, ou seja, o propósito de suprir as necessidades básicas diárias de indivíduos carentes. Isto não significa que um processo sistematizado não tenha sido considerado para estruturar o pensamento e as ações em design para o projeto de produto.

Para auxiliar na construção do método, foram consultadas propostas que tiveram o papel de apontar para a funcionalidade do método proposto, para garantir a inovação focando na situação e na definição do problema, sem focar em resultados de produtos já existentes (Guimarães, 2010; Rozemburg e Eekels, 1995; Delft Design Guide, 2014; Fogliatto e Guimarães, 1999). Ainda assim, foram consideradas propostas de autores da Engenharia, como Pugh (1990), para melhor esmiuçar a lista de requisitos de projeto, o que atende as especificações técnicas exigidas pelos procedimentos da administração pública ou de qualquer outra fonte de fomento, de caráter público, ao sistema de produção, como empresa focal para a iniciativa gestora.

Para as avaliações e ponderações dos requisitos, bem como orientação do processo de planejamento, análise e geração de indicadores para projetação e/ou desenvolvimento tecnológico, foram consideradas ferramentas como check lists, sob temáticas relacionadas ao controle de impactos ambientais - Ecodesign Check list (Brezet e Van Hemel, 1997) e matrizes do método de Design sociotécnico, um método que compatibiliza as necessidades humanas com a tecnologia disponível (Guimarães, 2010, p. 4; 24).

O método em design ao orientar o grupo social produtivo do sistema prevê ao estágio de urgência, um tempo curto para atendimento, portanto o método vai, no máximo, orientar o redesign de produtos já existentes no mercado. No estágio de manutenção, o método estará voltado ao desenvolvimento contínuo de inovações em produtos e processos tendo como meta a estabilização dos indivíduos no estágio sustentável. O método apresenta-se como mais um dos instrumentos a serem usados pela administração pública (nos dois tipos de iniciativa) para compor a implantação do sistema no local. Ele envolve o desenvolvimento tecnológico integrado e de planejamento estratégico para 
processos de inovação ou redesenho, a ser realizado pelo grupo social produtivo do sistema local. O método em design subdivide-se em: a) Planejamento; b) Análise; c) Projetação; d) prototipagem e testes, conforme descrito a seguir.

No momento de Planejamento (a), é feita uma lista de requisitos (Pugh, 1990) tendo como base o problema definido, na realidade do público-alvo, nas três características do sistema de produção para cada estágio da situação (urgência, manutenção e sustentabilidade) e na relação destes três fatores com cada dimensão da sustentabilidade (Sachs, 2004). Os requisitos são elencados em duas categorias: 1) os obrigatórios, que devem ser cumpridos para que a solução seja aceita, e 2) os desejados, aqueles que no possível devem ser cumpridos, tendo como fonte as investigações sobre o contexto social e os itens de demanda citados por indivíduos que estejam vivendo tais situações. A coleta de dados sobre a situação vivenciada pelos indivíduos, partindo de itens citados pelos próprios, poderá ser realizada com a ferramenta de Design Macroergonômico (DM), proposta por Fogliatto e Guimarães (1999), já utilizado no Capitulo II, como método para investigação e análise de dados dos projetos brasileiros.

No momento de Análise (b), os requisitos devem ser analisados em função dos insumos disponíveis, das habilidades disponíveis e dos impactos sociais, ambientais e econômicos das alternativas. Para tanto, podem ser utilizadas quatro matrizes indicadoras e orientadoras em design:

A primeira é a Matriz de Oportunidades de projeto (necessidades) x matériaprima (Guimarães, 2010), que terá o papel de mostrar as ofertas de matéria-prima local, podendo ser utilizada como recurso à cadeia de suprimentos;

A segunda é a Matriz de Correlação das Habilidades artesanais e industriais (mão de obra) com a capacidade de manufatura dos produtos com os insumos disponíveis no local. Nota-se que a fonte de mão de obra é tanto artesanal quanto industrial (micro e pequenas empresas).

Desta forma, com a informação do tipo de insumo, da habilidade e da capacidade de mão de obra, o passo seguinte será utilizar a terceira Matriz, a SQC - Sustentabilidade, Qualidade e Custo (Anexo II) (Guimarães, 2010), que considera os impactos dos recursos que serão utilizados no sistema de fabricação em todo ciclo do produto, desde a extração da matéria-prima até o seu pós-uso.

Com o resultado das duas primeiras matrizes e o check list feito pela matriz SQC, pode-se realizar a quarta Matriz, a Morfológica, para estimar as possíveis 
combinações de produto, entre insumo e processo, permitindo identificar outros parâmetros de desenvolvimento tecnológico em soluções para fabricação dos produtos.

No momento de Projetação (c), os projetos de inovação, ou redesenho, serão dirigidos pela: definição do problema, os requisitos obrigatórios e desejados, o resultado da matriz que relaciona os tipos de produtos necessários, em cada estágio da situação (urgência, manutenção e sustentabilidade), conforme figura 15. A situação de necessidades vividas por populações carentes, no Brasil, é um desafio para o design, porque nem sempre será suficiente o projeto de produto por inovação. $\mathrm{O}$ atendimento as necessidades de pessoas em estado de urgência nem sempre pode esperar por ações de inovação que se deem a médio ou longo prazo,. Para atender em curto prazo, cabem inovações incrementais, em produto ou processo. Nessas condições, sugere-se que seja realizada uma lista com a descrição de produtos já existentes que demandem re-design (Figura 30).

\begin{tabular}{|l|l|l|l|l|l|}
\hline \multicolumn{5}{|l|}{$\begin{array}{l}\text { Matriz de tipo de produtos por necessidades da população } \\
\text { = lista de produtos para fabricação }\end{array}$} \\
\hline \multirow{2}{*}{ Tipos de produtos } & Lista de necessidades como: & \multicolumn{2}{|l|}{} \\
\hline & Alimentação & Abrigo & Água & Saúde & Educação \\
\hline $\begin{array}{l}\text { 1. Produtos existentes } \\
\text { que satisfazem } \\
\text { necessidades, mas } \\
\text { precisam redesign por } \\
\text { ecodesign. }\end{array}$ & & & & & \\
\hline $\begin{array}{l}\text { 2. Produtos existentes } \\
\text { que precisam melhorias } \\
\text { e modificações } \\
\text { incrementais }\end{array}$ & & & & & \\
\hline $\begin{array}{l}\text { 3. Inovação - } \\
\text { desenvolvimento de } \\
\text { soluções para um } \\
\text { problema. }\end{array}$ & & & & & \\
\hline
\end{tabular}

Figura 30 - Lista de soluções para cada necessidade básica por tipo de produto.

$\mathrm{Na}$ fase de prototipagem e testes (d), as alternativas devem ser prototipadas, para posterior teste de insumos (componentes) e dos processos para fabricação dos produtos. Uma vez aprovadas, as soluções estão prontas para produção.

\subsection{5.}

Modelo de processo produtivo

Tendo em vista a ideia de produção local, mesmo em se tratando de uma demanda nacional, o que se propõe é a adoção do conceito e aplicação prática do 
sistema de produção distribuída (SPD), definido como a descentralização da produção, por meio de uma rede de fábricas geograficamente dispersas, mas que podem ser coordenadas por meio de tecnologia da informação (Kühnle, 2010; Whang e Shen, 2007). O Controle e a tomada de decisão ficam descentralizadas, pois cada unidade tem seu próprio controle, que está vinculado ao controle central, que é a Empresa Focal: o governo ou os aglomerados de agentes da sociedade civil, dependendo da estratégia da produção adotada.

A produção distribuída tem a vantagem de permitir a produção local, além da disseminação e compartilhamento da aprendizagem das práticas de projeto e produção pela interação do conhecimento tácito (da comunidade), técnicocientífico (das indústrias e instituições tecnológicas) de cada território (Maciel e Albagli, 2002, p. 2; Etkowitz e Zhou, 2006; Senhoras, 2008) e entre territórios (Whang e Shen, 2007).

Algumas vantagens da produção distribuída sobre a produção em massa são os impactos na sustentabilidade (Rauch et al., 2015) ao atender as suas 5 dimensões (Sachs, 2004, p. 15) que estão orientando esta tese: 1) dimensão social: a) maior proximidade com as necessidades locais, o consumidor; b) envolvimento do usuário no desenvolvimento de produto; 2) dimensão cultural e territorial: a) regionalismo e autenticidade, usando matéria prima e atendendo gosto local; b) fixação da pessoas nas regiões de origem, pelo fortalece das regiões produtoras, gerando trabalho e renda; 3) dimensão econômica: a) produção flexível em pequenas unidades para atender diferentes necessidades dos usuários (customização em massa de produtos) e a definição do comércio justo local para venda dos produtos logo que findar o estágio de urgência vivenciado pela comunidade; b) agregação de valor (e redução de custos) devido a customização dos produtos; c) redução dos custos de logística, pela otimização da logística, que passa a ser prioritariamente regional, que gera renda para as regiões e otimiza o just in time delivery; 4) dimensão ambiental: a) cadeia de suprimentos mais sustentável pois apenas algumas matérias primas serão transportadas por longa distância; b) redução de uso de energia; c) redução de emissão de gases; d) redução de tráfego; e) redução de resíduos. 5) dimensão política: a) governança democrática pela formação do capital social e grupo social produtivo no formato tríplice hélice dupla complementares. 


\subsection{6.}

\section{Logística de distribuição e reversa}

O modelo do sistema foi pensado para ter um ciclo produtivo fechado ao máximo, assumindo o modelo de gestão da produção limpa e ciclo de vida de produto do berço a berço, ao ponto máximo de otimização que seja possível alcançar. Desta forma, o subsistema de saída detém a logística de distribuição do produto no local, contudo com o planejamento de logística reversa já instituído pelo responsável do take back do produto usado nos locais definidos pelo grupo social produtivo. Após coleta, os produtos serão desmontados, um processo que já foi considerado no projeto de produto (DfD), para que cada parte tenha o reuso na reciclagem e o manejo dos componentes orgânicos para adubo.

O diferencial está em valorizar a possibilidade de manutenção do produto com o trabalho dos artesãos locais durante o ciclo de vida. Este serviço irá permitir o prolongamento do tempo de vida útil do produto, a motivação do consumo consciente e objetivamente garantir a fabricação de uma quantidade suficiente de produtos novos e redução da geração de resíduos. As partes sem condição de manutenção, mas que sejam compostáveis, serão reutilizadas no metabolismo biológico do local. Utilizando a rede de distribuição, as partes reprocessáveis podem retornar para a indústria, a fim de serem recicladas no metabolismo técnico.

Assim, os produtos deste sistema são projetados para serem desmontados e ter um tempo de vida útil não parametrizado pelo Código da defesa do Consumidor (CDC - Lei n 8.078 de 11 de Setembro de 1990).

Quanto a distribuição do produto ao público-alvo, deverá seguir os parâmetros dos três estágios de vivencia da situação (figura 15) ou seja: distribuído gratuitamente para os indivíduos no estágio de urgência, como atenção básica imediata por direito, até findar, ou pelo menos reduzir, o número de indivíduos nesta situação. No segundo estágio, a distribuição deve ser via comércio justo $^{25}$ (IPEA, 2011) quando produtos fabricados no local devem ter um preço de acordo com a realidade econômica das pessoas. Inclusive, se possível, a

${ }^{25}$ Comércio justo - é um movimento internacional para gerar benefícios ao produtor, dentre alguns segmentos como: produtos do agronegócio, artesanato e confecções, de comunidades, associações e cooperativas dos meios rural e urbano (SEBRAE, s/ d; IPEA, 2011). 
comercialização pode se dar com uma moeda local, a exemplo do Banco de Palmas (Melo, 2008; Freire, 2011) e seu sistema e-dinheiro (Banco Palmas, 2015). O sistema propõe um desenvolvimento local para desenvolvimento contínuo pelo trabalho, renda e valorização do potencial humano e ambiental do território, incentivando, desta forma, o empoderamento econômico destas pessoas, para atingir o terceiro estágio, o de vida sustentável (figura 31).

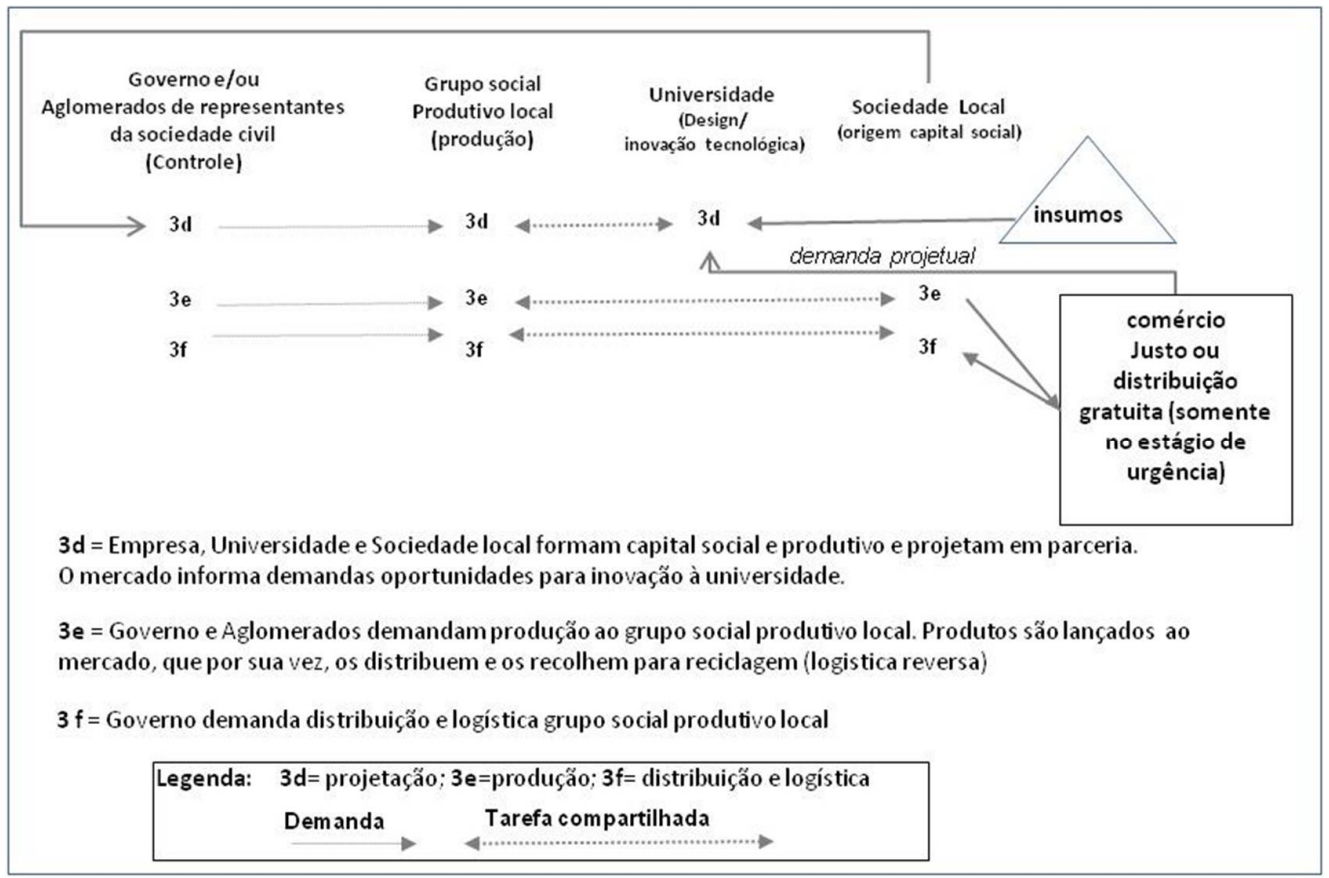

Figura 31 - Esquema operacional do sistema

\section{4 .}

Vantagens e desafios do sistema

\subsection{1.}

1‥ vantagem: direito de atenção básica e de participação efetiva

O sistema objetiva proporcionar provisão às necessidades básicas de populações em situação de carência, podendo ser implantado por duas iniciativas diversas, não restritivas, para que qualquer local possa usá-lo, sendo elas: governamental, como medida de Assistência Social, e por aglomerados de agentes sociais, representantes da sociedade civil local, inclusive o Governo, para preservação do Direito no recebimento do atendimento por estes indivíduos em carência, sem configurar uma ação de filantropia ou assistencialista.

A configuração estratégica e de planejamento do sistema assume um formato de rede de atores do tipo Tríplice Hélice Dupla complementares à 
sustentabilidade (THDS), proposta por Etkowitz e Zhou (2006), ou como Senhoras (2008, p. 147) denomina de Tripla hélice público-social, porque considera a sociedade ator imprescindível para operacionalizar os seus propósitos de medida de assistência social, através de um processo de inovação por desenvolvimento tecnológico de visão ampliada para as dimensões da sustentabilidade.

A proposta, sob o ponto de vista do design estratégico, se configura como um movimento de inovação tecnológica social (dos produtos e processos) pois as relações que se estabelecem transformam o modo de pensar uno e se expandem ao bem comum de um coletivo. A inovação tecnológica social, proposta no Capitulo II, figura 6, está voltada a atender necessidades sociais complexas de abrangências macro ou micro, independente da origem geográfica, contudo dependente das relações dos atores em rede.

\subsection{2.}

2- vantagem: do estado de urgência à auto-condição de compra do produto para suprir a necessidade, anteriormente assistida pelo Estado no estado de urgência

O sistema prevê ações de desenvolvimento humano, nos três estágios da situação vivida pelos indivíduos, até atingir um estado sustentável para não mais retornarem à situação inicial de dependência do recebimento gratuito do produto.. A definição do problema subdivide-se em compreender o problema social de atenção básica por três estágios da situação vivida: 1) em urgência, quando há total ausência de produtos ou serviços no atendimento à população; 2) manutenção, quando a população já ultrapassou a barreira da miséria e indigência, e já está suprida com o mínimo e pode usar suas capacidades para manter o processo de desenvolvimento humano, focando no ultimo estágio 3) o sustentável. O sistema propõe um desenvolvimento local e contínuo pelo trabalho, renda e valorização do potencial humano e ambiental do território, como o empoderamento econômico de uma parcela de seus residentes, considerados como mão de obra local do sistema, o que vem a contribuir para o alcance de um estágio de vida sustentável. O sistema prevê a distribuição gratuita dos produtos no estágio de urgência e atenção básica, e por comercialização dos produtos por comércio justo ao findar-se ou reduzir a condição de urgência. 


\subsection{3.}

\section{3a. vantagem: um capital social e produtivo que desenvolve o local}

A proposta para formação de grupos sociais produtivos, a partir do capital social do território, fortalece as ações do sistema nos três estágios de atenção da situação, porque após atenderem o momento de urgência, possuem capacidade de produção e geração de conhecimento tecnológico para manterem o sistema local em desenvolvimento atendendo a necessidade, gerando trabalho e renda. Ainda assim o formato de grupos sociais produtivos é modular em cada situação a ser atendida, portanto sempre poderá estar se formando, em quantidades necessárias a cada território, e suas especializações e experiências em complementaridade, estarão sempre reduzindo custos e tornando-se autossuficientes a cada experiência.

A proposta de desenvolvimento local faz motivar um movimento de cooperação entre os modos de produção da sociedade local, organizado pelo que foi denominado de grupo social produtivo do território, com uma formação que represente a estrutura produtiva para operacionalização do sistema no local e à distancia (produção distribuída). A proposta é motivar o desenvolvimento da inovação tecnológica, disseminando um processo de aprendizagem compartilhado, fundamental para o enfrentamento de cada desafio e melhorias no produto em relação aos seus fatores funcionais, simbólicos, ambientais e culturais.

\subsection{4.}

4a. vantagem: uma demanda de larga escala com funcionalidade territorial

Além de atender uma demanda de larga escala diante a realidade de carência de muitos brasileiros por produtos de atenção básica, o sistema contribui com o desenvolvimento local, porque seu planejamento visa a fabricação de produtos capazes de suprir necessidades básicas comuns para indivíduos de origens e culturas diversas, portanto funciona e opera dependente das potencialidades de cada território para melhor configurar as dimensões físicas e cognitivas do produto; parâmetros de projeto; produção e consumo diante o fator variabilidade em relação à diversidade de contextos sociais, ambientais e culturais do públicoalvo a ser atendido.

O sistema considera como fomentador de capital social produtivo e cadeia de suprimentos, um instrumento de desenvolvimento regional já estabelecido no 
País, que são os APL's, em todas as suas modalidades: industrial e intensivos em cultura, porque naturalmente já possuem uma rede de atores de especializações complementares em compartilhamento de saberes e fazeres, que pelo formato THDS poderão ampliar suas contribuições com o desenvolvimento local de seus territórios a partir de atividades sócio-econômicas-ambientais que amenizam necessidades básicas da população local: gerando trabalho, renda e valorização das pessoas e das riquezas materiais do local.

\subsection{5.}

5a vantagem: produtos duráveis projetados para sofrerem manutenção e serem desmontados após o uso e manejados ao reciclo biológico (compostagem) e técnico (novos componentes industriais)

Os produtos deste sistema são projetados para receber manutenção durante o uso e desmontar após o uso. Assim, a possibilidade de manutenção do produto, quando possível, valoriza o trabalho dos artesãos locais e os tornam atores imprescindíveis no ciclo de vida do produto e, principalmente, no seu prolongamento. Este serviço motiva o consumo consciente local, e objetivamente, define uma quantidade suficiente na fabricação de novos produtos, reduzindo a quantidade na geração de resíduos para serem manejados.

Dentre as alternativas de projetos analisadas, não foi identificada a participação de artesãos de artesanato utilitário para compor o grupo de mão de obra dos sistemas produtivos, tampouco como ator imprescindível para ampliar o tempo de vida útil do produto.

\subsection{6.}

6a vantagem: um método de design que projeta para a situação vivida pelas pessoas

O método de design tem como ponto de partida para seu desenvolvimento, compreender "a situação" ou o estado das pessoas (Ferreira, 2015) insatisfeitas, com um problema de necessidade básica à vida que precisam solucionar, não se fixando a analisar propostas de produtos já existentes, porque estes podem até auxiliar no atendimento ao estado de urgência, mas não serão capazes de aglutinar os requisitos definidos para que essas pessoas alcancem um estado sustentável para qualidade de suas vidas.

A demanda deste sistema é de larga escala porque deve atender muitas pessoas necessitadas, e territorial porque para funcionar e operar depende das 
mínimas e básicas características de cada território, que são diversas porque mudam de região para região do País. Portanto, a situação se mostra valorando proporcionalmente as dimensões da sustentabilidade no atendimento a um problema social complexo em cada território. Constitui-se em desafio para o design, porque diante os três estágios de atenção a uma necessidade básica nem sempre será suficiente o re-design ou um fator incremental em produto ou processo, mas planejar por uma estratégia que a inovação tecnológica social seja o objetivo.

\section{5 .}

\section{Conclusão do Capítulo 3}

O sistema de projetação, produção e distribuição foi desenvolvido para contribuir com a qualidade de vida das pessoas, de locais e culturas diferentes, que vivem em situação de carência de produtos de atenção básica, Suas características estratégicas são à base da formatação ética e operacional para:

- ser implantado por duas alternativas que garantam o direito de atendimento que os indivíduos possuem: por iniciativa governamental ou por aglomerados de agentes sociais representantes da sociedade civil (incluindo o governo).

- contribuir com o desenvolvimento local, considerando os três estágios de vivência da situação dos indivíduos: urgência, manutenção/desenvolvimento contínuo e sustentabilidade, motivando o desenvolvimento socioeconômico através da valorização dos ativos locais, definidos pela integração solidária, de natureza econômica, social, cultural e geográfica.

O sistema foca nas iniciativas de implementação de caráter público, com demanda de abrangência nacional e territorial, exigindo de sua "Empresa focal", equidade e transparência nos processos de desenvolvimento e operacionalização da produção, entre eles: o método de formação do capital social e produtivo; a formação da cadeia de suprimentos; o método em design do produto e seu ciclo de vida.

Estas exigências conferem a este sistema vantagens para desenvolver potencialidades locais inclusivas como:

1) sob a perspectiva do design, considerar uma estrutura das relações estratégicas para impulsionar a inovação tecnológica social (figura 6) e a 
formação de um capital social que torna as comparações e competições das atividades econômicas direcionadas ao bem comum do território;

2) a formação do capital social produtivo para atender a situação no estágio de urgência com metas de desenvolvimento para uma situação sustentável e de qualidade de vida;

3) motiva um movimento local de aprendizagem capaz de fazer fluir o desenvolvimento de inovações, baseado na cooperação entre conhecimentos tácitos e técnico-científicos para processos e produtos, bem como entre meios de produção industrial e artesanal, que geram melhores condições de trabalho, garantia de renda, maior controle dos impactos ambientais e valorização das habilidades locais.

4) O sistema propõe um desenvolvimento local para desenvolvimento contínuo pelo trabalho, renda e valorização do potencial humano e ambiental do território que, desta forma incentiva o empoderamento econômico dos habitantes, para que atinjam um estágio de vida sustentável.

O exercício diário de cooperação faz com que os agentes locais formadores do capital social produtivo percebam o território onde habitam como o mesmo local do sistema de produção, o que permite, com mais naturalidade, promover o controle dos impactos de suas atividades econômicas com requisitos aos ciclos de produção e de vida do produto que atendam as dimensões sociais, culturais, ambientais, políticas e econômicas. 


\section{4 ESTUDO DE CASO: APLICAÇÃO DO SISTEMA PROPOSTO PARA PROJETAÇÃO, PRODUÇÃO E DISTRIBUIÇÃO DO CALÇADO ESCOLAR DA REDE DE ENSINO PÚBLICA DO BRASIL}

Este capítulo tem o propósito de experimentar o sistema de produção e distribuição de produtos para atenção básica, desenvolvido no Capitulo 3, considerando a problemática do calçado escolar do ensino público do Brasil. O estudo justifica-se porque o calçado escolar é de uso comum, um produto de atenção básica por ter a função de proteger e prevenir a saúde, bem como preservar a dignidade do indivíduo com a possibilidade de estar com seus pés calçados quando presente em ambientes da sociedade, como a escola ou em outros frequentados durante a rotina diária do aluno. Nos casos daqueles que não têm nenhum poder de compra, o calçado escolar ${ }^{26}$ é uma das poucas opções de proteção segura para seus pés.

O calçado é um dos itens do material escolar a ser distribuído para os alunos matriculados na rede de ensino público do Brasil, e pode ser comprado e distribuído pelas Prefeituras Municipais de todo território nacional através de Pregão Nacional de Registro de Preços ou por licitação pública realizada no local, quando não há o produto disponível em Pregão. De acordo com o Fundo Nacional de Desenvolvimento da Educação - FNDE e as prefeituras dos municípios de Duque de Caxias e Belford Roxo, localizados no Rio de Janeiro, já vêm sendo realizada licitação local para compra do tênis escolar para os alunos destes municípios, de forma a gerar trabalho e renda no território (conforme relatos da Secretaria de Educação dos municípios, em entrevista concedida à pesquisadora).

${ }^{26}$ Calçado escolar: entendido, neste estudo, como qualquer modelo de calçado, reconhecido pelo usuário e de projeto parametrizado pelas especificações técnicas de segurança ao uso, para proteção dos pés. 
A formatação deste capítulo considerou as três principais características do sistema modelo: iniciativa governamental, como medida de assistência social ${ }^{27}$, preservando o direito no atendimento às necessidades dos alunos; contribuição para o desenvolvimento local e a promoção de um movimento de inovação tecnológica entre os agentes do capital social e produtivo, nos territórios atendidos. Quanto à demanda de produção do calçado escolar, estimou-se o contexto de abrangência nacional e territorial. A demanda do território apresentase como o recorte de pesquisa que delimita o trabalho de campo desta tese, tendo sido escolhidos três municípios para o exercício desta prática:

a) o município de Novo Hamburgo, localizado no Estado do Rio Grande do Sul, com uma demanda de 23.426 alunos matriculados na rede de ensino público fundamental. No município, não há distribuição do kit de uniforme escolar, nem de calçados escolares, apesar de ser uma cidade reconhecida como uma das mais antigas aglomerações produtivas da indústria coureiro-calçadista ${ }^{28}$, localizada no Polo Calçadista do Vale do Rio dos Sinos (Calandro e Campos, 2013, p.1).

b) os municípios de Duque de Caxias e Belford Roxo, localizados no Estado do Rio de Janeiro, que distribuem, respectivamente, 80 mil e 43 mil kits de uniformes escolares, sendo o tênis um dos componentes. Outra particularidade que somou para a escolha destes municípios é que neste território há um bairro limítrofe, chamado Lote XV, que abriga um APL de calçados em expansão e implementação, para formalizar e regularizar as atividades da maioria dos empresários locais. Este APL, que está sendo formado com apoio governamental, já conta com 80 micros e pequenas empresas, com meios de produção mais artesanais do que mecânicos, e que têm em seu histórico uma relação cultural com a habilidade profissional de sapateiros de bairro, ou como "casqueteiros", o nome popular a eles concedido naquele território. Estes artesãos demonstram ter o perfil do artesanato utilitário, conforme a descrição feita por Barroso Neto (2011, p. 5). O APL do Lote XV é formado por organizações empresariais.

27 Declaração Universal dos Direitos Humanos, 1948, Artigo XXV; BRASIL, Decreto no. 591, Artigo 11, 1992.

28 Polo Calçadista do Vale do Rio dos Sinos - Não oficializada como APL por qualquer instituição governamental, conforme esclarecimento da ABICALÇADOS (Anexo III). 
Os recortes qualificam-se por apresentarem contextos sociais diferentes, contudo relacionados à mesma problemática social do estudo de caso desta tese: a necessidade de calçados escolares para os alunos de baixa renda matriculados na rede pública de ensino de cada um dos territórios. Os contextos sociais abordados oportunizam ao trabalho de campo descrever experiências reais diversas, contribuindo para a geração de dados que, analisados, darão subsídios para aceitar ou recusar a hipótese desta tese.

O capítulo apresenta a formação do grupo social produtivo de cada um dos 3 territórios, a aplicação do método em design junto a estes grupos, que envolveu a apresentação da ficha técnica do calçado escolar, feita, pela pesquisadora, com base nas normas a serem seguidas, e dos testes e ensaios exigidos como verificação das especificações técnicas que se apresentaram como requisito obrigatório no método de design, a qual orientou o grupo para o desenvolvimento dos protótipos de calçados escolares. É descrito o funcionamento do sistemapiloto experimentado em cada território e seus resultados considerando:

- a Análise situacional e Planejamento estratégico (Fase 1) do sistema que foi totalmente executada;

- Planejamento da implementação e gestão do sistema produtivo (Fase 2) não foi realizado como exigido no modelo, porque trata do planejamento para implantação e gestão do sistema em situação real.

- o Método de projetação e produção distribuída (Fase 3): subsistemas de entrada (capital social, mão-de-obra e gestão da cadeia de suprimentos do sistema de produção); transformação (método em design para projeto de produto e do processo produtivo), saída e retroalimentação (logística de distribuição e reversa) que não obteve a elaboração do plano-mestre de produção, um stage gate quando todos os recursos para fabricação e montagem dos bens e serviços já estariam estrategicamente disponíveis para serem operacionalizados pela Programação da Produção (Tubino, 2007, p. 3; 4).

Contudo, com os resultados obtidos nas fases 1 e 3 do modelo já se pode assumir resultados, visto que protocolos de verificação permitem uma análise descritiva dos recursos necessários para a elaboração de um plano de produção operacional, incluindo a logística de distribuição e reversa. 


\section{1. \\ Situação social a ser atendida: a Indústria calçadista brasileira e a fabricação/distribuição do calçado escolar (Fase 1)}

A história da indústria de calçados no Brasil começa no século XVIII, com as atividades de subsistência: pecuária e agricultura (Navarro, 2006). Em 1888, a primeira fábrica de sapatos foi fundada no Sul do Brasil e, ao longo do tempo, com o aumento do consumo de calçados, ações voltadas para a industrialização da produção de couro foram necessárias em várias regiões do Brasil, principalmente com investimentos em tecnologia. Este movimento determinou a principal característica da indústria calçadista brasileira: a sua organização geográfica e socioeconômica por polos produtivos.

Os polos produtivos são identificados, principalmente, pelo tipo de calçado fabricado e o destino dado à produção (se mercado interno ou exportação). Os calçados femininos e de alto desempenho são produzidos pelo Polo calçadista gaúcho, os esportivos (tipo tênis) pelo Polo mineiro e os calçados infantis, pelo Polo paulista. Já os calçados de couro, destinado à exportação, são produzidos por dois Polos distintos: pelo nordestino, devido a sua localização estratégica para embarques e pelo do centro-oeste, situado na maior região curtidora do país.

Outra característica que favorece a indústria calçadista é a organização por clusters: a capacidade das empresas estarem agrupadas geograficamente com atividades inter-relacionadas (Porter, 1989). O cluster gaúcho já foi considerado o maior do mundo, mas atualmente ele vem perdendo força pois esta havendo uma mudança do polo calçadista gaúcho para o nordeste, em virtude da migração de muitas empresas em busca de melhores condições fiscais,

Santos (2008) identificou, com uma investigação sobre o método de desenvolvimento de calçados, realizada com profissionais de uma Empresa calçadista de grande porte, e com profissionais independentes que atuam no Polo Calçadista Gaúcho, que o calçado é reconhecido como um objeto de moda, produzido à luz do que é concebido e lançado ao mercado no Hemisfério Norte (Europa principalmente), e que o método de desenvolvimento utilizado pelas Empresas fabricantes brasileiras continua, desde a década de 70 (Carrasco, 1970), utilizando a cópia como ferramenta principal. Dados que podem ser confirmados, em 2015, pela entrevista realizada, no Vale do Rio dos Sinos, com 3 professores vinculados a instituições de ensino, 10 profissionais exercendo a função de 
designers, vinculados a empresas fabricantes de calçados para o mercado de moda e 5 empresários fabricantes de calçados. Os profissionais foram contatados através da indicação pela administração das instituições de ensino e entidades de classe, as entrevistas foram realizadas, presencialmente e orientadas por 1 pergunta aberta, sendo ela: 1) Como você desenvolve calçado?

A investigação de Santos (2008) apontou que o conceito de design não era claro para a formatação das empresas do setor, não foram identificados critérios que considerem a gestão em design como estratégia de negócio de competitividade e inovação (Borja de Mozota, 2003). Em 2015, há o reconhecimento do papel do design para a competitividade da empresa e para a gestão ambiental no que tange ao controle da geração de resíduos, contudo ainda não há a compreensão da contribuição do designer, no que Rozenfeld et al. (2006) consideram como gestão do processo de desenvolvimento do produto. Desse modo, estes fatores continuam incentivando a cópia, reduzindo o potencial de diferenciação no mercado, e a ausência de atividades integradas da equipe de desenvolvimento de produto, não permitindo feedback para o planejamento estratégico das atividades da empresa.

O Governo Federal do Brasil, desde 2008, vem instituindo ações que apoiam e incentivam a competitividade do calçado brasileiro no mercado interno e estrangeiro, através da Agência Brasileira de Desenvolvimento Industrial (ABDI) e da Agência Brasileira para Exportação (APEX). O principal objetivo é focar suas atividades em programas e projetos, estabelecidos pela Política de Desenvolvimento Produtivo - PDP, com estratégias para o fortalecimento da competitividade do setor calçadista, com o uso articulado de incentivos fiscais, financeiros, regulação, poder de compra e apoio técnico (ABDI, 2008; 2012). Em 2012, segundo a ABICALÇADOS E ASSINTECAL, os esforços foram concentrados, da mesma forma, em programas para o gerenciamento de resíduos e gestão ambiental, considerando a Política Nacional de Resíduos sólidos como parâmetro (LEI No 12.305, 2010).

\subsection{1.}

Os entraves ao fornecimento de calçados para o sistema público de ensino

Em 2009, o MEC começou a preparar um pregão nacional para iniciar, em 2010, e em grande escala (50 milhões), as transações de compra dos kits de 
uniforme escolar. O objetivo seria dar transparência, extinguir problemas com as licitações (ou a falta delas), baixar custos, estabelecer padrões de qualidade e permitir que o pregão seja feito por itens separados, para que os estados e municípios possam formar seus kits de uniformes de acordo com cada realidade e necessidade.

O numero é de alto risco para um sistema de produção, o que piora quando pensamos que esse calçado tem ciclo de vida de seis meses (inverno e verão) para algumas regiões do País. Nos moldes atuais, as empresas julgam que atender o pregão é incompatível com suas estratégias de negócios: elas deixariam de atender seus mercados para atender as escolas diante o número efetivo de alunos matriculados por região do Brasil; não tem capacidade de atender a diversidade de atributos desse produto; a logística de entrega é difícil e o planejamento da produção arriscado, pois o edital de compra não define a venda com um número de pares mínimo, a demanda é aleatória e a compra não é certa, depende das Prefeituras querer comprar ou não.

A última atualização realizada sobre o assunto junto ao FNDE foi em fevereiro de 2014, quando fizeram nova chamada pública para o registro de preços do tênis escolar. Houve somente uma empresa participante que apresentou a contento todos os documentos exigidos. Contudo, antes de entregar um pedido de 700 mil pares de calçados à Cidade de São Paulo, algumas de suas amostras não atenderam as especificações técnicas contidas no edital, sendo o processo de fornecimento cancelado pelo FNDE. A empresa, para não encerrar suas atividades e demitir 500 funcionários, tentou resolver o problema apresentando laudos técnicos que comprovariam que as especificações técnicas, exigidas em Edital, foram atendidas. Contudo, os laudos não tiveram legalidade reconhecida junto ao Laboratório executor, contratado pela Empresa.

Foi instaurada uma investigação pelo Ministério público, mas a Prefeitura de São Paulo conseguiu autorização do FNDE, para realizar licitação regional, e não deixar de fornecer os calçados às crianças, apesar do ano letivo de 2014 já ter sido comprometido na entrega de calçados escolares para as crianças paulistas. Os primeiros pares só poderiam ser entregues no segundo semestre de 2014.

Desde as primeiras tentativas para o registro de preços do calçado, o FNDE vem tentando aproximação com a indústria calçadista do Brasil. Por conta deste último episódio, houve uma maior aproximação, tendo acontecido reuniões 
periódicas entre o FNDE e a entidade representativa das indústrias de calçados do Brasil, a ABICALÇADOS. As empresas calçadistas mostram interesse em participar do pregão, e estão dispostas a conversar com o FNDE para tentar uma solução.

No entanto, ainda em 2014, a ABICALÇADOS, que representa a opinião dos fabricantes, considerou ser muito difícil garantir a presença das empresas junto ao pregão, visto que as condicionalidades do edital de participação não mudaram quanto à logística de entrega, as especificações técnicas que restringem a participação de empresas fabricantes, a sazonalidade da demanda e o comprometimento de fabricação com um número determinado de pares por semestre sem ter conhecimento da demanda real e a região a solicitar.

O grupo vem tentando uma melhor adequação entre os fatores de produto, fabricação, logística e exigências técnicas da ABNT para futuros editais.

Segundo Caldas e Nonato (2012):

No plano jurídico, entre as normas que atualmente regem o processo de aquisição governamental no Brasil estão a Lei de Responsabilidade Fiscal $\mathrm{n}^{\circ} 101 / 200$ e a Lei de Licitações e Contratos 8.666/93, criadas com o intuito de promover maior transparência e controle sobre os gastos públicos. Alterada em 2010 (Lei 12.349/10), o art. $3^{\circ}$ da Lei 8.666/93, reza que a função da licitação não é tão somente obter a proposta mais vantajosa, mas promover o desenvolvimento inclusivo, de forma a direcionar a demanda do Estado para o desenvolvimento local.

\section{2.}

\section{Definição do problema (Fase 1)}

A demanda de calçado escolar é de 15,4 milhões, para atender os alunos de famílias beneficiárias do Programa Bolsa Família que tiveram frequência escolar acompanhada no período de abril a maio do ano de 2014 (MDS, 2014). Esta camada da população não tem poder de compra para o calçado escolar porque, segundo as informações quanto a preços enviadas pelas empresas fabricantes, Coopershoes, da marca ALLSTAR e Companhia Alpargatas S.A, da Topper, eles custam respectivamente: $\mathrm{R} \$ 113,27$ (cento e treze reais e vinte e sete centavos) o desejado pelas meninas (Figura 32), da marca AllStar, e R \$ 70,60 (setenta reais e sessenta centavos) o desejado pelos meninos, da marca Topper, estilo Society (figura 33). Estes preços significam 42,14\% (tênis masculino) e 67,60\% (tênis 
feminino) do valor médio de $\mathrm{R} \$ 167,56$ (cento e sessenta e sete reais e cinquenta e seis centavos $)^{29}$ pago pelo Beneficio a uma família (MDS, 2015).
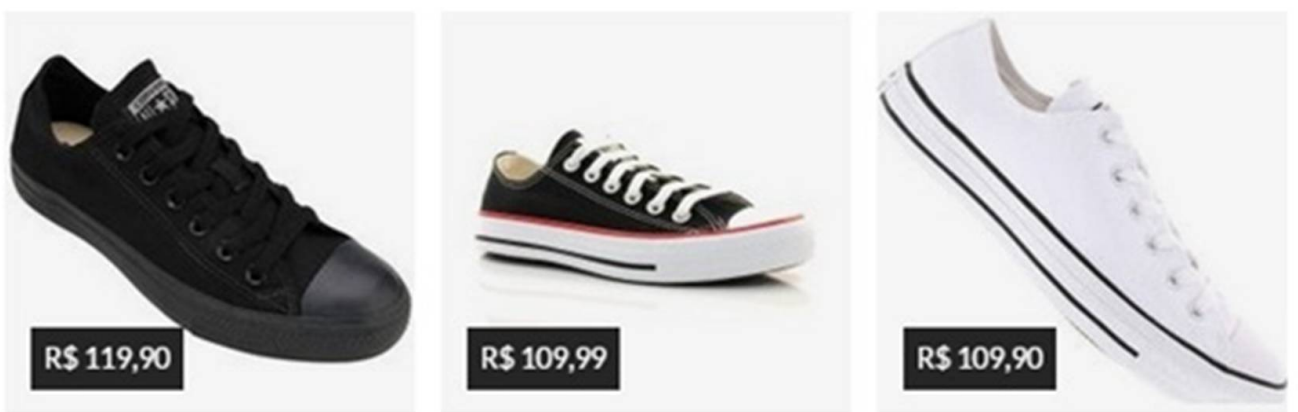

Figura 32 - Valores dos tênis da marca AllStar, desejado por meninas. Preços em reais (Fonte Empresa fabricante: Coopershoes Ltda., em 2015).
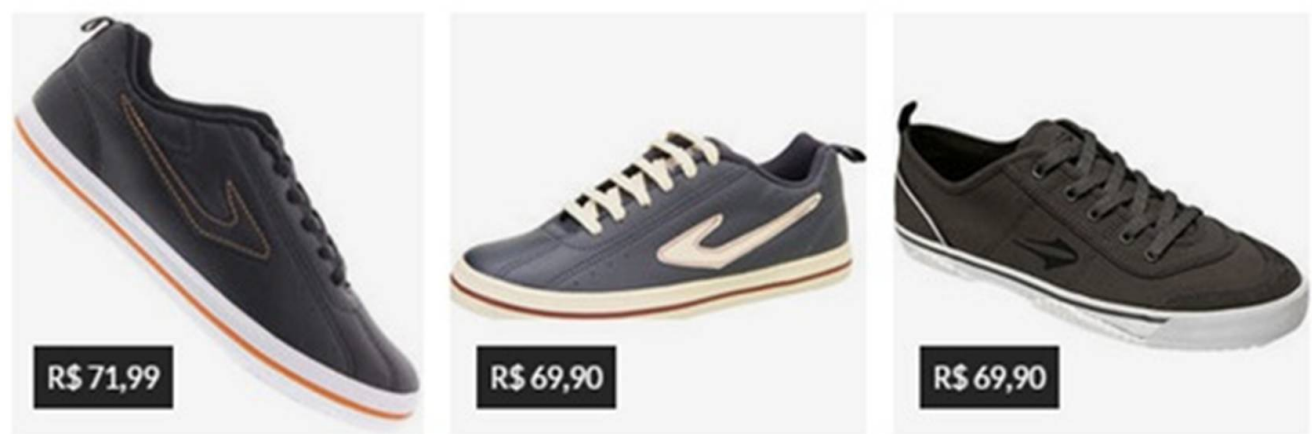

Figura 33 - Valores dos tênis estilo Society, desejado por meninos. Preços em reais (Fonte Empresa fabricante: Alpargatas S.A, em 2015).

Desta forma, a utilização do sistema de produção e distribuição do calçado escolar pode atender uma demanda governamental, ou por aglomerados de agentes da sociedade civil, e garantir a igualdade de direitos dos alunos das escolas públicas ao acesso a melhores condições de permanência na escola. Ravena (2015), ao dissertar sobre as Escolas como resistência no Semiárido, citou que já passados 25 anos de decreto do Estatuto da Criança e do Adolescente (ECA) ainda são muitos os desafios para assegurar os direitos das crianças e dos adolescentes brasileiros, como o direito à educação presente no capítulo IV do Estatuto, em que se afirma a igualdade de condições de acesso e permanência na

29 Valores pagos, pelo Beneficio do Programa Bolsa Família, referentes ao mês de janeiro do ano de 2015 (MDS, 2015). 
escola. Pela figura 34, pode-se identificar a capacidade do sistema em prestar esta contribuição social.

\begin{tabular}{|l|l|}
\hline \multicolumn{2}{|l|}{ Qualificação do sistema para contribuição com o problema do calçado escolar } \\
\hline Iniciativa & $\begin{array}{l}\text { Governamental ou por aglomerados de agentes sociais locais (inclusive o } \\
\text { governo). }\end{array}$ \\
\hline Produto & Calçado escolar para alunos de escolas públicas do Brasil. \\
\hline $\begin{array}{l}\text { Necessidades a } \\
\text { serem atendidas } \\
\text { pelo calçado } \\
\text { escolar }\end{array}$ & $\begin{array}{l}\text { Preservar a dignidade humana dos alunos garantindo o direito ao calçado } \\
\text { escolar. Proteção aos pés durante a marcha; Prevenção a doenças de solo } \\
\text { (geominthoses) e doenças musculoesqueléticas; Segurança durante as } \\
\text { atividades escolares; Proteção contra as intempéries do clima; Proteção } \\
\text { em ambientes que não o escolar. }\end{array}$ \\
\hline $\begin{array}{l}\text { Escala de } \\
\text { produção do } \\
\text { sistema e } \\
\text { contribuições }\end{array}$ & $\begin{array}{l}\text { 1) Larga escala tem demanda nacional - Ex.Cadeia suprimentos. } \\
\text { 2) Escala territorial** desenvolve o local envolvendo recursos ao sistema } \\
\text { as ofertas: matéria-prima, mão de obra, conhecimentos técnico-científicos, } \\
\text { tácitos e industriais, formação de capital social e demanda local (fatores do } \\
\text { produto, trabalho, renda). }\end{array}$ \\
\hline $\begin{array}{l}\text { Distribuição à } \\
\text { comunidade }\end{array}$ & $\begin{array}{l}\text { Distribuição gratuita até findar a situação, pela Medida Assistencial } \\
\text { (direito), e manter o sistema para desenvolvimento local. }\end{array}$ \\
\hline $\begin{array}{l}\text { (**) Escala territorial - a fabricação com mão de obra local, não significa pequena escala, } \\
\text { desde que garanta atendimento aos usuários. Deve satisfazer fatores culturais, ambientais e de } \\
\text { desenvolvimento local. }\end{array}$ \\
\hline
\end{tabular}

Figura 34 - Configuração básica do sistema de produção do calçado escolar do Brasil.

\section{3. \\ Características estratégicas do SPPD do calçado escolar (Fase 1)}

A primeira característica do sistema dá ênfase à responsabilidade governamental em atender as necessidades básicas das populações. Tomando como base a problematização, do Governo Brasileiro, através do MEC/FNDE, que é o responsável pela compra dos calçados escolares. Uma ação que não apresenta no formato (governo-empresa) que não reproduz qualquer formato de rede de atores ao desenvolvimento de inovação tecnológica, apresentado pela literatura estudada (Sábato e Botana (1975), Etzkowitz e Leydesdorff (1998); Etkowitz e Zhou, 2006; Senhoras (2008, p. 139); Carvalho (2009, p. 111); BRASIL (2010, p. 18). Diferenciando-se dos propósitos do sistema-modelo, conforme Figura 6, Capitulo II, que prioriza a inovação tecnológica social considerando o desenvolvimento humano e local, pela evolução que o individuo deve ter em 3 estágios de vivencia da situação (urgência, desenvolvimento, vida sustentável).

A segunda característica é a oportunidade que o sistema possui em contribuir com o Desenvolvimento local. A produção do calçado escolar pode tomar como referência o exemplo do que já vem ocorrendo com o Programa Nacional de Alimentação Escolar (PNAE) que compra alimento direto dos 
agricultores locais para compor a dieta alimentar das escolas do Brasil (sem atravessador). Esta opção de compra, por chamada pública que dispensa processo licitatório, deixaria de ter os entraves que vem ocorrendo na compra por pregão e licitação nacional, porque o controle dos requisitos de produto, constantes do edital de chamada para fornecimento do calçado, poderão ser controlados pelo próprio local, através da unidade executora (UEx), eleita pelo capital social e grupo social produtivo local do sistema de produção do calçado. Uma dinâmica que acontece no território que garante os fatores de produto citados pelos alunos ao calçado e contribui com o desenvolvimento local, gerando trabalho e renda na valorização do ecossistema e dos saberes e fazeres do local, tanto artesanal como tecno-industrial.

A terceira característica do sistema define os recursos e desenvolvimento de inovação tecnológica cooperativo para seu planejamento operacional através:

- do formato de organização da Indústria Calçadista no Brasil, que tem sua estrutura formada por Polos Produtivos, reconhecidos por clusters ou arranjos produtivos locais, diante as inter-relações que ocorrem entre as empresas pertencentes aos aglomerados ou em trabalho compartilhado à distância com outros.

- pelo tradicional processo produtivo da indústria calçadista brasileira, do tipo semi-industrial, intensivo em mão de obra e exigente em desenvolvimento tecnológico e inovação, especialmente quando se trata da manufatura de calçados do tipo esportivo, que atende a demanda do mercado de moda e especificações técnicas da indústria desportiva profissional.

Este mix entre meios de produção industrial (máquinas e equipamentos), artesanal (manual) e tecnológico (softwares específicos), como mostra a figura 35, é uma rotina produtiva de Empresas calçadistas de grande porte, como a Vulcabrás Azaléia S.A, que detém em seu portfólio calçados esportivos (profissionais e uso comum), de moda e de segurança para uso profissional. 


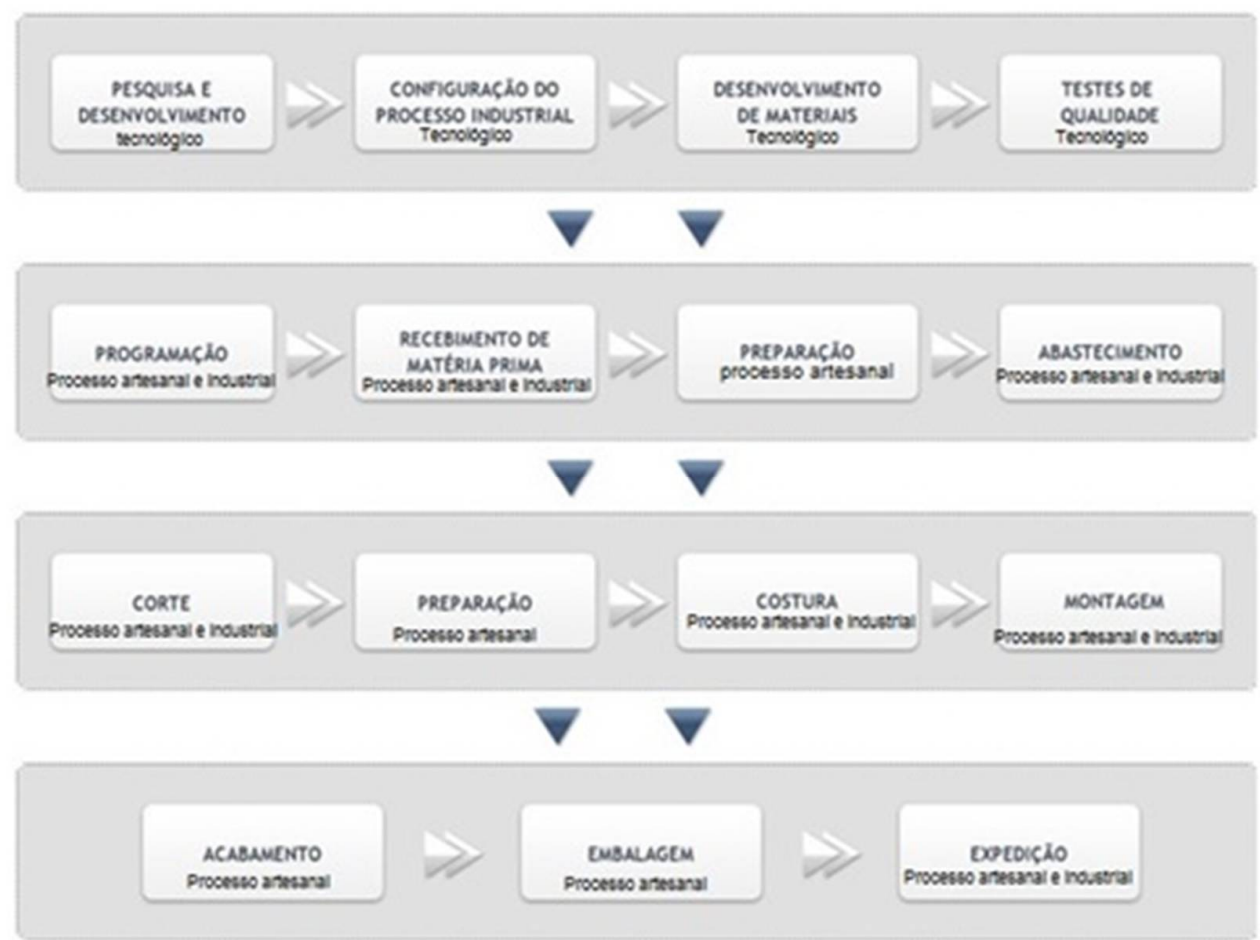

Figura 35 - Etapas padrão do processo produtivo de calçados esportivos, femininos e botas para uso profissional da Empresa Vulcabrás (2015).

$\mathrm{Na}$ figura 35, dentre as 15 etapas de processos, 4 demandam tecnologia mais sofisticada utilizando para suas atividades softwares ou sistemas de informação, 7 são atividades que alternam uso de máquinas e equipamentos industriais e 4 são processos manuais, totalmente artesanais, com uso intensivo de mão de obra. Contudo a indústria calçadista tem habilidades no uso da produção distribuída, quando é de sua prática, por exemplo, localizar os Centros de Pesquisas e Desenvolvimento (P\&D’s) das Empresas de grande porte em centros urbanos como São Paulo ou em Pólos Produtivos, como Novo Hamburgo, onde a mão de obra é especializada para desenvolvimento tecnológico de produto, e via canais de comunicação, trabalham à distancia com parques fabris, localizados no Nordeste do Brasil, para a fabricação dos produtos desenvolvidos.

Entretanto, o diferencial proposto por este sistema de produção de calçados escolares é aproveitar este know-how da indústria calçadista, que está pulverizada $^{30}$ (mas nem todas em comunicação entre si) no Brasil por Polos

30 Mas nem todos em comunicação integrada para desenvolvimento tecnológico. Exceto aqueles que possuem Empresas de grande porte que já fazem da produção distribuída uma prática: com $P \& D$ 's nos centros urbanos e parques fabris em lugares, como o Nordeste do 
industriais, APLs de MPME's, sapateiros de bairro, e ateliês de trabalhadores artesanais da confecção de calçados e artefatos de couros e peles (FIRJAN, 2013), como recursos à escala territorial do sistema.

\section{4.}

\section{Demanda e local do sistema (Fase 1)}

Este item estará apresentando a demanda do sistema de produção, com uma visão de abrangência nacional (Federação) e territorial, considerando a realidade de cada local, definido como recorte para o trabalho de campo desta tese. São eles Novo Hamburgo (RS), Belford Roxo (RJ) e Duque de Caxias (RJ).

\subsection{1. Demanda Nacional}

De acordo com o Instituto Nacional de Estudos e Pesquisas Educacionais Anísio Teixeira (INEP) (2014; 2015), o número de alunos matriculados no ensino fundamental das redes estaduais e municipais, urbanas e rurais em tempo parcial e integral foi de 28.459.667, em 2014. Já no primeiro semestre de 2015 foram de 21.431.522 matrículas nas redes de ensino público de todo o Brasil (demanda nacional) não estando incluídos, nestes números, os alunos da educação básica matriculados em creches e pré-escola, e do ensino médio (incluindo o médio integrado e normal magistério), os alunos da Educação de Jovens e Adultos (EJA presencial Fundamental), Médio (incluindo o EJA integrado à educação profissional), bem como as matrículas dos alunos da Educação Especial.

A distribuição de alunos matriculados por região geográfica do Brasil, que configura a demanda territorial para o sistema de produção do calçado escolar, composto por gráficos do cenário real, de cada estado, e um gráfico que mostra o cenário por região geográfica do Brasil.

Entretanto, ao analisar a demanda geral, sob a perspectiva do índice de desenvolvimento humano municipal (IDHM), foi identificado um grupo de brasileiros em situação de urgência para atendimento, definindo territórios, em prioridade, para implantação do sistema.

O método utilizado para coleta destes dados foi correlacionar o número de alunos matriculados por região, com indicadores do Atlas do Índice de 
Desenvolvimento Humano Municipal (IDHM), com o percentual (\%) de pessoas em domicílios vulneráveis à pobreza e sem ensino fundamental completo. Os resultados permitiram identificar: o ranking dos municípios de todo território nacional com prioridade de atendimento e o número de alunos a serem atendidos por região geográfica do Brasil. Do resultado geral, foram extraídos os estados com a média mais baixa dos índices de IDHM e listados na figura 36.

\begin{tabular}{|c|c|c|c|c|c|c|c|}
\hline $\begin{array}{l}\text { Estados } \\
\text { brasileiros }\end{array}$ & $\begin{array}{l}\text { População } \\
\text { do Estado } \\
\text { (IBGE, } \\
\text { 2015). }\end{array}$ & $\begin{array}{l}\text { IDHM } \\
(2010)\end{array}$ & $\begin{array}{l}\mathrm{N}^{\circ} \text {. total de } \\
\text { matrículas } \\
\text { Ensino } \\
\text { Fundamental }\end{array}$ & $\begin{array}{l}\% \text { de } \\
\text { pessoas em } \\
\text { domicílios } \\
\text { ninguém } \\
\text { tem ensino } \\
\text { fundamental } \\
\text { completo } \\
\text { (2010) }\end{array}$ & $\begin{array}{l}\% \text { de } \\
\text { pessoas em } \\
\text { domicílios } \\
\text { vulneráveis } \\
\text { à pobreza e } \\
\text { ninguém } \\
\text { tem } \\
\text { fundamental }\end{array}$ & $\begin{array}{l}\mathrm{N}^{\circ} \text {. de } \\
\text { pessoas } \\
\text { em } \\
\text { domicílios } \\
\text { vulneráveis } \\
\text { a pobreza }\end{array}$ & \begin{tabular}{|l|} 
Mão de obra \\
necessária \\
para fabricar \\
demanda de \\
calçados do \\
estado \\
(1 pessoa em 3 \\
meses produz \\
1056 pares) \\
\end{tabular} \\
\hline Pará & 8.175 .113 & 0,646 & 1.094 .566 & 33,07 & 25,24 & 3.239 & $1.036,52$ \\
\hline Paraíba & 3.972 .202 & 0,658 & 31.398 & 36,55 & 25,89 & 1.534 & 29,73 \\
\hline Bahia & 15.203 .934 & 0,66 & 1.733 .290 & 33,6 & 23,62 & 6.437 & $1.641,37$ \\
\hline Acre & 803.513 & 0,663 & 119.444 & 33,21 & 24,79 & 324 & 113,11 \\
\hline Sergipe & 2.242.937 & 0,665 & 250.552 & 34,12 & 24,62 & 911 & 237,27 \\
\hline Pernambuco & 9.345 .173 & 0,673 & 980.618 & 32,94 & 23,15 & 4.037 & 928,62 \\
\hline Amapá & 766.679 & 0,674 & 107.054 & 26,49 & 20,65 & 371 & 101,38 \\
\hline Ceará & 8.904 .459 & 0,682 & 971.266 & 27,76 & 19,66 & 4.529 & 919,76 \\
\hline $\begin{array}{l}\text { Rio Grande } \\
\text { do Norte }\end{array}$ & 3.442 .175 & 0,684 & 347.992 & 29,28 & 19,9 & 1.730 & 329,54 \\
\hline Rondônia & 1.768 .204 & 0,69 & 213.364 & 30,19 & 15,49 & 1.142 & 202,05 \\
\hline Tocantins & 1.515 .126 & 0,699 & 1.738 & 26,79 & 17,6 & 861 & 1,65 \\
\hline
\end{tabular}

Figura 36 - Lista dos Estados prioritários em atendimento em relação ao baixo índice de IDHM.

A figura 37 mostra que se fosse possível uma relação direta entre a necessidade de mão de obra para a produção de calçados, por estados prioritários em atendimento, com o número de pessoas vivendo em domicílios vulneráveis e pobreza, o sistema já estaria contribuindo com a geração de trabalho, renda, e desenvolvimento humano em todos os territórios.

Os resultados mostram que as iniciativas de implementação do sistema, quando realizadas por políticas públicas ou medidas assistenciais governamentais de abrangência nacional, deveriam levar em consideração os estados e seus municípios com maiores índices de pobreza e miséria. Se o modelo de planomestre de produção deste sistema fosse utilizado para abrangência nacional, a estratégia de ação seria de curto prazo, focada ao estágio de urgência. 


\subsection{2.}

\section{Demanda territorial do Município de Novo Hamburgo}

O município de Novo Hamburgo possui escolas públicas de ensino fundamental, municipais e estaduais. Desta forma o método de investigação sobre a demanda do município foi estruturado pelo levantamento de dados sobre: a) a distribuição de kits de uniformes escolares; b) se o calçado era um dos componentes do kit, c) sobre a origem geográfica dos fornecedores e d) sobre o número de alunos matriculados na rede de ensino do município. Foram realizados contatos presenciais com fontes primárias como: as Secretarias Municipais (SME) e Estaduais (SEED) de Educação, para solicitar entrevistas com os responsáveis sobre o assunto. Foi elaborado um questionário contendo 12 perguntas (Apêndice II) para orientar as entrevistas. Fontes secundárias foram acessadas para coleta de dados estatísticos quanto à população dos alunos do município, como o Censo Escolar de 2014, e seus dados prévios de 2015 foram solicitados pela pesquisadora, via email, ao INEP - Instituto Nacional de Estudos e Pesquisas Educacionais Anísio Teixeira) (INEP, 2015).

A SME de Novo Hamburgo, para responder ao questionário, solicitou à pesquisadora que fizesse um pedido oficial junto ao protocolo da prefeitura. $\mathrm{O}$ procedimento foi realizado, em junho e agosto de 2015, e a resposta concedida em setembro de 2015 foi: não distribuímos uniformes escolares porque o município não apresenta esta demanda. E não temos informações da opinião, dos pais ou alunos, sobre o uso do uniforme escolar.

Em relação à resposta da Prefeitura, apesar do IDHM de Novo Hamburgo ser de 0,747 (Atlas Brasil 2010), o percentual de crianças vulneráveis à pobreza é de $27,73 \%$. O percentual de crianças pobres é de $8,70 \%$ e o percentual de mães, chefes de família, sem fundamental e com filho menor, é de $48,45 \%$, do total das mães chefes de família, com filho menor e 9.499 famílias são beneficiárias do Programa Bolsa Família, o que representa um percentual de 19,90\% da população, assumindo que a média familiar seja de 5 componentes, considerando que a população de Novo Hamburgo é de 238.940 (IBGE 2010).

A Secretaria de Estado não quis receber o questionário para resposta posterior, tendo preferido dar as informações por telefone, justificando que havia greve dos servidores em função da crise econômica vivida pela administração 
pública do Estado do Rio Grande do Sul, desde o início do ano de 2015. Entretanto, a resposta foi:

Não há distribuição, e pelo que percebemos, nem há condições financeiras para isso. Se o governador não consegue pagar os salários dos servidores, imagina se ele vai autorizar compra de uniformes escolares. A situação prioritária hoje é matar a fome dos servidores do Estado e de suas famílias (Entrevista concedida em agosto de 2015).

O número de alunos matriculados no ensino fundamental e o número de escolas do município, tomando como referência, o Censo Escolar de 2014 e as planilhas prévias do Ano de 2015 (INEP, 2015) são de:

- o número de alunos matriculados no ensino fundamental da rede pública, estadual e municipal é de 23.426 alunos (INEP, 2015) (figura 37).

- Novo Hamburgo possui 110 escolas de educação infantil e ensino fundamental (período de 8 e 9 anos), dentre este número estão contempladas as escolas de gestão Estadual e Municipal.

\begin{tabular}{|l|c|}
\hline $\begin{array}{c}\text { Unidades da } \\
\text { Federação - Municípios }\end{array}$ & $\begin{array}{c}\text { Número de } \\
\text { alunos matriculados }\end{array}$ \\
\hline Estadual Urbana & 7.379 \\
\hline Estadual Rural & 270 \\
\hline Municipal Urbana & 3.798 \\
\hline Municipal Rural & 266 \\
\hline Estadual e Municipal & 11.713 \\
\hline Total & $\mathbf{2 3 . 4 2 6}$ \\
\hline
\end{tabular}

Figura 37 - Número de alunos matriculados, no ensino fundamental, na rede pública de ensino do município de Novo Hamburgo (INEP, 2015).

\subsection{3.}

\section{Demanda territorial dos municípios de Belford Roxo e Duque de Caxias, no estado do Rio de Janeiro}

O método de coleta de dados foi estruturado da mesma forma que no município de Novo Hamburgo.

As etapas iniciaram, previamente, por contato telefônico com as Secretarias Municipais de Educação dos municípios para solicitar a entrevista presencial ou preenchimento do questionário. Foram coletados dados em fontes secundárias, sobre a demanda dos alunos matriculados no município: no banco de dados do Censo Escolar de 2014 (INEP, 2014) e dados prévios de 2015 do INEP.

Os dados do INEP (2015) mostram que, no estado do Rio de Janeiro, 1.212.438 alunos foram matriculados no ensino fundamental nos primeiros 
semestres do ano de 2015. Já os municípios de Duque de Caxias e Belford Roxo tiveram, respectivamente, 72.424 e 21.503 alunos matriculados no ensino fundamental, representando 7,75\% do total de alunos do estado do Rio de Janeiro.

\subsection{4.}

\section{Local do sistema}

A localização do sistema, a partir das informações coletadas, em entrevista com os agentes sociais dos territórios selecionados depende de 3 condições, sendo uma imprescindível, que é a $1^{\mathrm{a}}$ delas:

$1^{\mathrm{a}}$.) o interesse político em implementar o sistema nos territórios e o grau de entrosamento entre os agentes sociais que receberem a proposta do sistema no território;

$2^{\mathrm{a}}$.) o atendimento sob a perspectiva do Índice de Desenvolvimento Humano (IDHM) que permite identificar localidades em prioridade de atendimento no Brasil; e

$3^{\mathrm{a}}$.) a relação da capacidade de produção com a disponibilidade de mão de obra em relação à demanda do território, a presença de instituições tecnológicas para apoiar as inovações e a oferta de matéria-prima local, ou o mais próximo do território.

\section{5.}

Planejamento da implementação e gestão do sistema produtivo (Fase 2)

O funcionamento do sistema de produção do calçado escolar tem o planejamento de seu cronograma em função do calendário escolar das escolas, por semestre letivo, de cada município. O calendário escolar é marcado por 7 pontos de interseção: 1) o período de matricula do aluno, 2) a distribuição do uniforme escolar e dos materiais didáticos, 3) a data de início das aulas do primeiro semestre, 4) a data de início das férias do meio do ano (inverno), 5) a data de início das aulas do segundo semestre, 6) a data final das aulas do ano letivo e 7) período de férias de final e início do próximo ano (verão).

O período de matrícula é sempre realizado 1 mês antes de iniciar as férias de final de ano, que normalmente tem um período de 3 meses, por isso marca o início do planejamento da produção para o sistema do calçado escolar, porque é neste momento que se tem a chance de coleta de dados antropométricos e de fatores do produto de cada aluno que se matricula nas escolas do município. Estes dados são 
importantes para alimentar o sistema de informação para o planejamento da produção local do calçado escolar. No cronograma de planejamento este três meses de férias serão considerados tempo de coleta de dados, desenvolvimento projetual do calçado, definição de protótipo e processos de fabricação, formação da cadeia de suprimentos, compra e entrega dos insumos, fabricação e entrega dos calçados aos usuários.

Os dados antropométricos fornecem o número de calce por informação do aluno ou por desenho do tamanho real do pé do aluno (em folha de papel comum e escaneada) e o perímetro do pé, medido com uma fita métrica simples envolvendo a região do peito do pé. Estes dados irão contribuir para o planejamento da escolha de formas e matrizaria do solado. Ainda assim, a longo prazo estará formando um banco de dados antropométrico, sobre o pé de uma população brasileira de 06 a 14 anos de idade (em média, considerando atípicos para mais idade). Contudo, a curto prazo será utilizada para: planejamento da escala de formas dos calçados e planejamento da escala antropométrica do conjunto de matrizes para fabricação do solado. Os benefícios desta coleta atende fatores biomecânicos do pé, portanto conforto e segurança da saúde e durante a marcha.

Os dados coletados sobre os fatores simbólicos e estéticos permitirão identificar requisitos desejados para uso no desenvolvimento projetual do calçado escolar. É a oportunidade dos alunos incluírem, na ficha de matrícula, resposta a pergunta: como você imagina seu calçado escolar? Como o uniforme escolar não tem obrigatoriedade de uso, e a pesquisa junto ao grupo amostral de alunos do ensino fundamental mostrou que eles não gostam de usar uniforme escolar com qualquer simbologia que remeta "a uniforme do governo", esta informação permitiria customizar, ao máximo, as funções simbólicas e estéticas, auxiliando na configuração da cartela de matérias-primas para cabedal e dos solados do primeiro semestre. Isto garante atender ao gosto dos alunos para cada território brasileiro, portanto seu uso, justificando sua compra. Além disso, os dados formam um banco de simbologias e ícones da expressão cultural e de gosto desta população jovem, de cada território brasileiro, e por época.

Outros dados que irão auxiliar na composição dos requisitos biomecânicos poderão ser informados pela escola no momento de matricula como: o tempo de 
hora/aula e programa na disciplina de educação física e demais atividades que exijam movimentos motores e em marcha dos alunos.

Uma estimativa de valor do produto também poderá ser informada pelos pais dos alunos, na ficha de matrícula, o que irá auxiliar no planejamento do produto e de sua produção. A pergunta sugerida é: qual o valor de um calçado escolar? Quanto o calçado deveria custar?

Outras perguntas poderiam ser feitas: quanto ao desgaste do calçado: onde gasta mais o seu calçado escolar? Por quê? Quanto tempo dura o seu calçado escolar?

\section{6.}

\section{Formação do capital social (Fase 3)}

Como se está realizando um trabalho de campo para experimentar o sistema modelo, e não se detém o instrumento da administração pública, a chamada Audiência Pública, para convidar os possíveis agentes sociais para a formação do capital social do sistema, a alternativa foi formar o capital social nos três territórios da seguinte forma:

$1^{\text {a) }}$ Foram listados os agentes sociais da sociedade civil que tinham o perfil para apoiar o sistema com o propósito de apresentar o projeto e perguntar se tinham interesse em participar como agente do capital social e do grupo social produtivo, bem como era percebida a contribuição da Instituição junto ao projeto. Então foram listadas as instâncias governamentais, governanças de arranjos produtivos locais, artesãos do calçado (sapateiro de bairro), entidades de classe (empresas fabricantes de insumos e produtos e profissionais da área), centros tecnológicos, fóruns de movimentos sociais, grupos de referencia de assistência social e empresas fabricantes de calçados;

$2^{\mathrm{a}}$.) Foram realizados contatos telefônicos e presenciais para fazer a entrevista com os agentes sociais identificados de cada território;

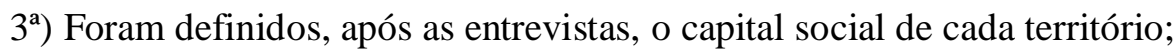

$4^{\mathrm{a}}$ ) Foi solicitado ao grupo a indicação do agente social para assumir a governança local do sistema de produção, tanto para o capital social como para o grupo social produtivo.

Contudo, cada território demonstrou suas particularidades, que serão descritas a seguir. 


\subsection{1.}

\section{Formação do Capital Social da Demanda Nacional}

A identificação dos possíveis agentes sociais formadores do capital social que estaria impulsionando, na escala federal, Políticas públicas ou medidas assistenciais que promovam apoio à implementação do sistema nos territórios, foi realizada a partir dos agentes sociais que mostraram participação durante a descrição do estudo de caso do calçado escolar, e as informações já descritas no Capitulo III sobre o assunto. Assim, foram identificados 6 principais agentes sociais (figura 38 ):

1) as instituições governamentais que estarão atuando como gestoras, nas instâncias federal, estadual e municipal, da organização e execução dos instrumentos públicos para implantação do sistema nos territórios: como o FNDE, as Secretarias Municipais e Estaduais de Educação e as escolas;

2) os Arranjos produtivos locais com capacidade de oferta em recursos para o sistema nos territórios como: APL's da indústria calçadista, APL's da economia criativa como os de Artesanato;

3) demais setores produtivos localizados o mais próximo, geograficamente aos territórios, com capacidade de fornecimento;

4) Instituições de ciência e tecnologia para cooperação, localizadas no território ou o mais próximo, geograficamente;

5) fóruns locais de movimentos sociais: para motivar as atividades localmente junto aos demais agentes político-sociais necessários ao funcionamento do sistema; 
6) Comunidade local a contribuir de forma participativa com as atividades do sistema.

\section{FORMAÇÃO DO CAPITAL SOCIAL DO SISTEMA DE PRODUÇÃO DO CALÇADO}

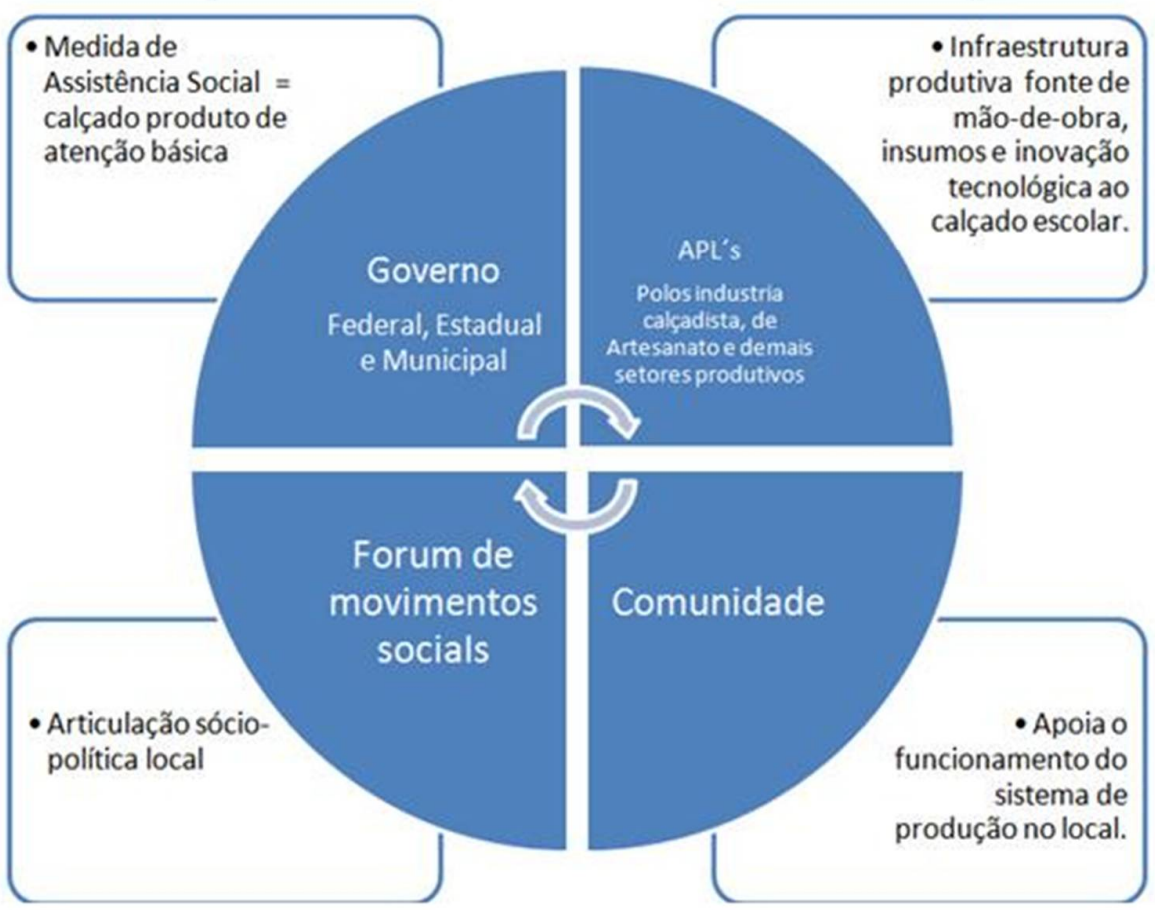

Figura 38 - Formação do Capital social do sistema de produção

\subsection{2.}

\section{Formação do Capital social territorial de Novo Hamburgo}

Na cidade de Novo Hamburgo, pode-se encontrar iniciativas da sociedade civil a partir de entidades de classe, vinculadas às atividades econômicas locais, como a indústria calçadista, moveleira e comércio, e de organizações populares de fazeres e saberes locais, como a agricultura familiar, artesanato utilitário (costureiras, sapateiros e marceneiros), organizações governamentais municipais, como a Incubadora Popular da Prefeitura Municipal e Instituições de ensino, públicas e particulares, para o ensino superior, técnico e fundamental.

Para identificar os agentes sociais e montar uma formação para o sistemapiloto do território de Novo Hamburgo, o método utilizado foi: a) contatar, presencialmente, cada agente social com perfil para participação; b) apresentar o projeto; c) identificar o interesse na participação; d) identificar com o agente social sobre a percepção de seu papel no sistema. 
Aceitaram participar do experimento 5 instituições da sociedade civil de Novo Hamburgo. A lista e a forma de participação, apontada por cada uma delas, podem ser analisadas a seguir:

- A Incubadora Popular da Prefeitura definiu-se como: o espaço referencial (endereço) para as atividades do experimento, visto que seu espaço já é utilizado por grupos da sociedade. Pela sua experiência de trabalho no município mostrouse capaz de assumir o papel de unidade executora, representante da prefeitura municipal.

- O Fórum de economia solidária é o espaço, no município, onde se discute um modo de economia alternativa, como a economia solidária. Definiu-se como motivador da oferta de mão de obra e componentes (resíduo da indústria calçadista, previamente analisados), bem como orientador de uma gestão econômica alternativa aos grupos sociais produtivos.

Ao fórum foi realizada uma pergunta: seria possível pensar em uma cadeia produtiva com empreendimentos solidários e industriais? A resposta foi:

A realidade dos empreendimentos solidários já é esta, não há insumos suficientes a partir dos empreendimentos solidários; a indústria vem participando. Contudo há como encontrar uma forma de cooperação entre, ECOSOL e INDUSTRIAL, focando na responsabilidade ética, social, no respeito ao ambiente e com isso na aprendizagem entre realidades para o desenvolvimento sustentável do município. O que não pode é pensar em ser excludente, o que seria um contrassenso aos princípios da economia solidária, pois estamos num município que toda sua economia gira em torno da indústria e participa ativamente do cenário econômico do Brasil.

- A ASSINTECAL - Associação Brasileira de Empresas de Componentes para Couro, Calçados e Artefatos, única entidade de classe, que foi contatada, da mesma forma que as demais, e aceitou contribuir com o trabalho. Colocou-se disponível para contatar e negociar futuras necessidades do projeto com empresas fabricantes de componentes para o calçado escolar, sobretudo as empresas fabricantes de solados. Não se responsabilizando financeiramente por desenvolvimentos de inovação tecnológica junto às empresas, caso necessário.

- As instituições técnico-científicas, responsáveis por ensaios técnicos laboratoriais para calçados, localizadas no município, foram contatadas, colocaram-se disponíveis a fornecer informações, contudo não poderão assumir os 
ensaios técnicos dos protótipos fabricados pela pesquisadora ou pelos grupos sociais produtivos do sistema-piloto, diante os custos que existem para a instituição na realização dos mesmos. Os ensaios deverão ser pagos.

- O Sindicato dos trabalhadores da indústria do calçado foi contatado, inclusive para identificar se os sapateiros de bairro seriam associados da entidade de classe. A resposta quanto a contribuir com o projeto foi positiva, mas disseram que não sabiam como. Quanto aos sapateiros de bairro disseram que eles não participam da mesma categoria dos trabalhadores filiados ao sindicato, pois estes profissionais trabalham realizando consertos e não para a indústria, e que por isso não poderiam ajudar no agrupamento desta categoria, caso fosse necessário.

- Os sapateiros de bairro do município foram contatados, porque o projeto do sistema considera estes trabalhadores do artesanato utilitário como uma das principais fontes de mão de obra, não somente para a fabricação local do calçado escolar, como para a manutenção deste produto enquanto ele ainda estiver sendo usado pelos alunos. Nesse sentido, foi realizada uma investigação sobre os sapateiros de bairro do município de Novo Hamburgo.

Identificou-se que existem duas famílias do município que mantém 3 lojas abertas, uma na periferia e duas no centro da cidade, para realizar consertos nos calçados. Uma loja, de uma das famílias, com o passar do tempo iniciou atividades como ateliê de modelagem e amostras (protótipos) para a indústria do calçado. Essas lojas foram contatadas para que o projeto fosse apresentado.

Nas entrevistas, foi identificado que os sapateiros não tinham interesse em participar na manufatura e sim nos consertos (manutenção dos calçados), alegando que possuem muito serviço de conserto e que são atividades que levam tempo para fazer, porque são manuais. Nas palavras de um dos entrevistados:

"consertar calçado é muito mais trabalhoso do que fabricar um novo. Mas que não podem reclamar, porque tem muito serviço. Vocês deveriam entregar este trabalho às fabriquetas de bairro, lá eles têm condições de fabricar e estão em situação muito difícil."

A postura dos sapateiros de bairro de $\mathrm{NH}$ abre um espaço para se pensar em pesquisar porque as pessoas estão procurando consertar seus calçados, demonstra ser negativa a hipótese de que o ofício do sapateiro está sendo extinto, o que vem fortalecer a proposta do sistema-modelo em considerá-los como mão de obra na manutenção dos calçados escolares durante o uso. 
Apesar dos sapateiros indicarem as fabriquetas para manufatura dos calçados escolares de Novo Hamburgo, identificou-se que este artesão está sendo valorizado pelos usuários, o que permite estimar que em outros territórios, diferente do perfil de uma cidade polo calçadista, pode-se ter o aceite destes artesãos como mão de obra na manufatura e na manutenção (consertos).

- Micro e pequenas empresas fabricantes de calçados, as chamadas fabriquetas de bairro, conforme indicado pelos sapateiros. Dentre as 10 contatadas uma aceitou participar desde que os protótipos fossem pagos. As demais justificaram: precisam de trabalho e não de tentativas; gastam dinheiro e tempo, sem retorno com pesquisas. Outras solicitaram pagamento para participarem.

Em relação à questão de gênero tratada no Capitulo III, item 3.2.2 outras alternativas de agentes locais surgiram para contato: a Pastoral da Criança do Vale dos Sinos e Novo Hamburgo, e a Secretaria de Desenvolvimento Social de Novo Hamburgo que mantém um Centro de Referência de Assistência Social- CRAS para capacitação profissional. O CRAS Canudos I, unidade do bairro Canudos (bairro industrial), em Novo Hamburgo, possui oficinas artesanais de motivação das capacidades de ex-trabalhadoras da indústria de calçados, que vivem em situações de vulnerabilidade social, porque não conseguem conciliar o cuidado com os filhos e a carga horária exigida pelas fábricas de calçados. Mulheres do Grupo Esperança, informaram que gostariam de participar como mão de obra na fabricação do calçado escolar, para venda e para seus próprios filhos.

A coordenadora regional da Pastoral da Criança recebeu a ideia do projeto com muito entusiasmo e permitiu o acesso da pesquisadora aos supervisores dos grupos de Novo Hamburgo e São Leopoldo, que desenvolvem trabalhos com algumas mães cadastradas. O primeiro contato foi com as mães da Vila Rio do Sinos, em São Leopoldo, mas não houve aceite porque a maioria destas mulheres trabalham no "lixão" da Vila, comandado pelo "dono do lixão" uma pessoa com poder de mando as famílias que trabalham para ele, portanto a permissão de restringe-se somente a participar da Pastoral porque é distribuída alimentação.

O grupo da Pastoral e a pesquisadora foram "convidados a sair da comunidade pelo "dono do lixão" e pelo "guarda do tráfico de drogas local", mas esta experiência negativa evidenciou a importância do trabalho de construção do capital social e produtivo, e como são delicadas as questões que impactam nesta construção. De acordo com o Prof. Nilton Bahlis, integrante do grupo de 
saúde do Programa Brasil sem Miséria, pesquisador da Fundação Oswaldo Cruz, a inclusão produtiva de alguns grupos em situação de vulnerabilidade, só e possível se, antes, profissionais da saúde e da assistência social prestarem um cuidado de atenção básica primária.

- Foi contatado um modelista de solados e um modelista de cabedal, que aceitaram participar do projeto piloto oferecendo suas habilidades profissionais artesanais para desenvolvimento da modelagem do cabedal (pago) do calçado e do perfil do solado desejado.

Os resultados mostram que foi possível formar, no município de Novo Hamburgo, um capital social, um grupo produtivo e a Empresa focal, composto por instituições governamentais e agentes da sociedade civil, conforme o modelo que o sistema propõe. Contudo, ficou evidente a questão econômica necessária para desenvolvimento de inovações tecnológicas. Neste caso, será realizada uma tentativa com a instituição governamental e por parcerias. Entretanto, esta é uma variável que deve ser considerada como imprescindível para o grupo social produtivo dos sistemas a serem implantados.

\subsection{3.}

Formação do Capital social territorial do Rio de janeiro, municípios de Duque de Caxias e Belford Roxo

O método utilizado para a formação do capital social dos municípios de Duque de Caxias e Belford Roxo foi: a) contatar, presencialmente, cada agente social com perfil para participação; b) enviar os propósitos do projeto via email e contatos telefônicos; c) identificar o interesse na participação; d) identificar, com o agente social, a percepção de seu papel no sistema.

A formação do capital social do Município de Duque de Caxias já inicia com:

- a participação da instituição governamental, porque a prefeitura de Duque de Caxias já distribui 80 mil pares de calçados para crianças matriculadas nas escolas do município, priorizando o desenvolvimento local, ao convidar somente empresas locais para participar da licitação de compra pública do produto.

- a presença da formação do APL do Calçado no Lote XV, representado pelo Sr. Avelino, presidente da COOPFARJ - Cooperativa de Fabricantes de Calçados de Duque de Caxias. Ele aceitou desenvolver protótipos para identificar a capacidade produtiva das empresas de Duque de Caxias a fim de atender a 
demanda municipal de calçados escolares, considerando os requisitos obrigatórios e desejados do método em design do modelo.

- a participação da Secretaria de Desenvolvimento Econômico do Estado do Rio de Janeiro (SEDEIS), instituição governamental coordenadora das Atividades do APL Lote XV. A representante, Sra. Luciana Leis, aceitou participar apoiando e divulgando a pesquisa junto aos agentes sociais do APL em formação, e prestando informações socioeconômicas sobre o APL, bem como sobre o Centro tecnológico que está em construção, no município de Belford Roxo.

- a participação da Secretaria de Desenvolvimento Econômico da Prefeitura de Duque de Caxias, representada pelo Sr. Wellington. Ele aceitou participar, também apoiando e indicando a pesquisa junto aos agentes sociais do APL, e prestando informações socioeconômicas do município.

Não se obteve acesso as demais entidades de apoio, como o SEBRAE e a FIRJAN. Quando contatados, o SEBRAE indicava a FIRJAN e esta por sua vez indicava a SEDEIS, única instituição que realmente forneceu informações sobre o APL do calçado do Lote XV, além dos agentes locais.

Nenhum retorno positivo foi recebido dos agentes sociais contatados no município de Belford Roxo. Inclusive, o presidente da Associação dos Fabricantes de calçados, em entrevista à pesquisadora, demonstrou desconforto e desinteresse em participar, porque:

Não existe apoio da Prefeitura para formação do Arranjo Produtivo Local (APL), portanto não tendo importância qualquer atividade que irá se relacionar com o APL LOTE XV.

Desta forma, sem a informação da Secretaria de Educação e o não aceite dos fabricantes de calçados, o município de Belford Roxo deixou de fazer parte do grupo de territórios para experimentar o sistema-piloto, ficando mantida a participação do Município de Duque de Caxias.

Desta forma, enquanto projeto-piloto, pode-se assumir que o capital social do sistema do Lote XV está formado pelo grupo de agentes sociais do APL que aceitaram participar: pela Cooperativa de Fabricantes de Calçados de Duque de Caxias (COOPFARJ), com suas empresas e sua cadeia de suprimentos, pela Secretaria de desenvolvimento econômico do Estado do Rio de Janeiro (SEDEIS), a Secretaria de Desenvolvimento econômico da Prefeitura de Duque de Caxias, representada pelo Sr. Wellington e o modelista que estava trabalhando com o Sr. 
Avelino na montagem do protótipo. O grupo demonstrou interesse em experimentar, oficialmente, o SPPD após a implementação do APL do Calçado.

4.7.

Oferta de mão de obra e insumos para o sistema de produção do calçado escolar (Fase 3)

\subsection{1.}

Uma visão nacional para a disponibilidade de mão de obra

O método utilizado para identificar a disponibilidade de mão de obra utilizou indicadores com dados coletados junto às fontes de referência, conforme figura 39 .

\begin{tabular}{|l|l|}
\hline \multicolumn{1}{|c|}{$\begin{array}{l}\text { Itens de investigação de habilidade e } \\
\text { conhecimentos autóctones da indústria } \\
\text { calçadista do Brasil }\end{array}$} & Fontes de coleta de dados \\
\hline $\begin{array}{l}\text { - A localização no território nacional dos Polos } \\
\text { Calçadistas do Brasil } \\
\text { - O número de empresas fabricantes de calçados } \\
\text { - O número de empresas fabricantes de calçados por } \\
\text { região do Brasil. }\end{array}$ & $\begin{array}{l}\text { Ministério do Trabalho através dos } \\
\text { dados contidos no Cadastro Geral } \\
\text { de Empregados e Desempregados - } \\
\text { CAGED }\end{array}$ \\
\hline $\begin{array}{l}\text { - Total de Profissionais no Brasil - Trabalhadores } \\
\text { artesanais da confecção de calçados e artefatos de couros e } \\
\text { peles/Moda }\end{array}$ & $\begin{array}{l}\text { - Total de Profissionais para o Município Novo Hamburgo } \\
\text { - Trabalhadores artesanais da confecção de calçados e } \\
\text { artefatos de couros e peles/Moda } \\
\text { - Total de Profissionais para o Município Duque de } \\
\text { Caxias - Trabalhadores artesanais da confecção de } \\
\text { calçados e artefatos de couros e peles/Moda }\end{array}$ \\
\hline $\begin{array}{l}\text { - o número de empresas fabricantes de solados } \\
\text { esportivos por região do Brasil. }\end{array}$ & no Brasil - SISTEMA FIRJAN \\
\hline
\end{tabular}

Figura 39 - Fontes de coleta de dados sobre a disponibilidade de mão de obra no Brasil e nos territórios.

Como o interesse é propor um sistema de produção do calçado escolar, é fundamental a investigação das habilidades e conhecimentos tácitos que estão diretamente relacionados às atividades econômicas e culturais dos territórios brasileiros. Portanto, o primeiro caminho de condução desta investigação foi mapear os territórios relacionados ao calçado, por meio da identificação da localização dos Polos da Indústria Calçadista brasileira e os Arranjos Produtivos Locais do Calçado.

O Brasil possui nove Polos calçadistas distribuídos nas regiões CentroOeste, Nordeste, Sudeste e Sul (figura 40). Os Polos são reconhecidos pelo número de empresas fabricantes, pela característica do produto fabricado ou 
porque o grupo de empresas da região está organizado e oficializado pelo

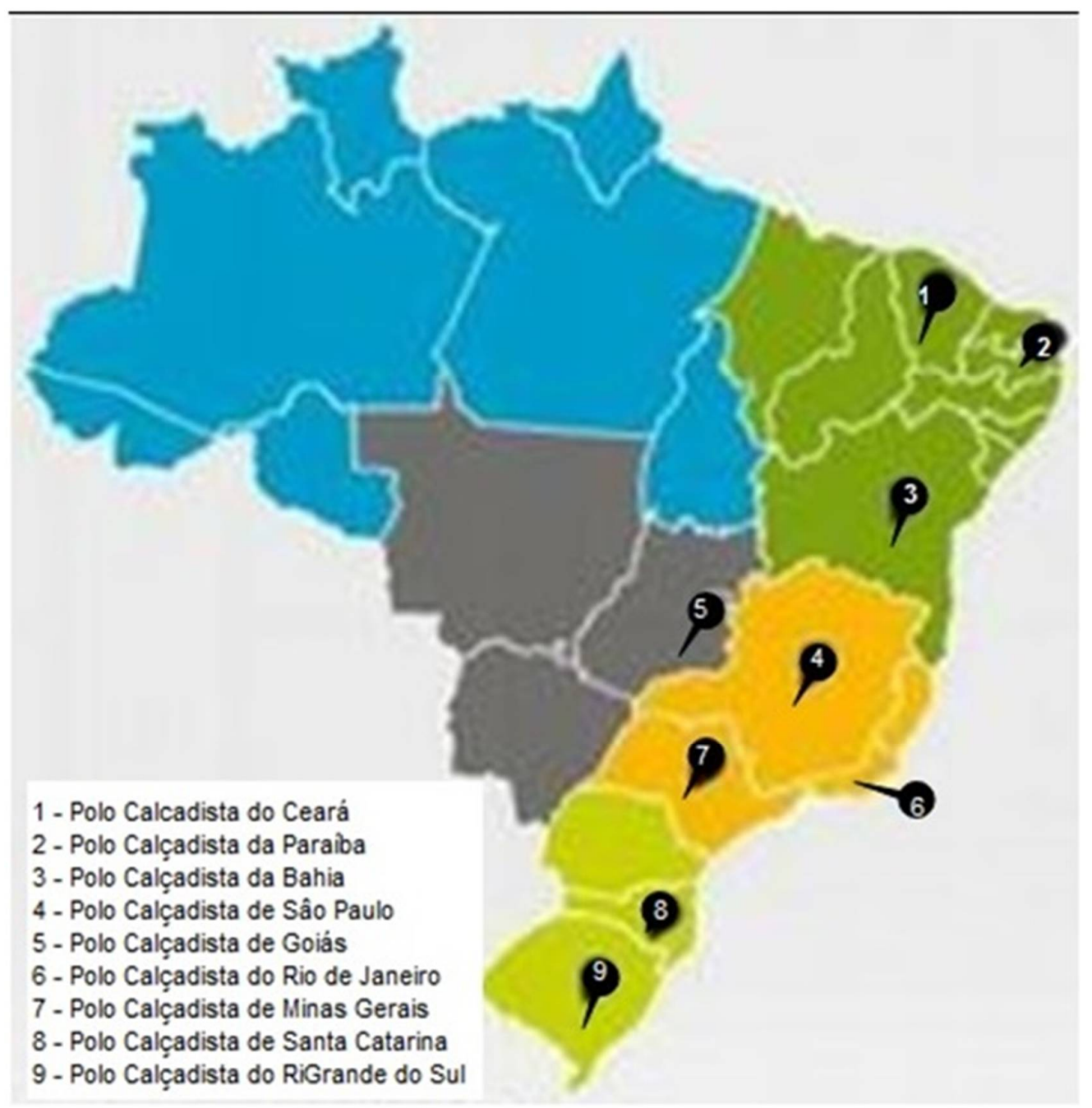

Ministério da Indústria e do Comércio como um Arranjo Produtivo Local (APL).

Figura 40 - Localização dos Polos Calçadistas Brasileiros por regiões geográficas do Brasil.

A Região Sul está composta por 2 Polos: o Polo Calçadista do Estado do Rio Grande do Sul, considerado um dos principais clusters calçadistas do mundo, com APL's localizados nas cidades do Vale do Rio dos Sinos, Vale do Paranhana, Vale do Taquari e Serra Gaúcha, com 2.929 empresas fabricantes (\% Brasil: 35,8), empregando 118.397 trabalhadores (\% do Brasil: 34,0). Sua característica é fabricar calçados femininos, calçados de segurança e esportivos, abrigar os setores de pesquisa e desenvolvimento das Empresas de grande porte e os escritórios das Companhias de exportação; e o Polo Calçadista do Estado de Santa Catarina formado pelas cidades do Vale do Rio Tijucas dentre elas: Tijucas, Canelinha, 
Nova Trento, Major Gercino e São João Batista, com um total de 287 empresas (\% do Brasil: 3,5 ) com um total de 8.155 mil pessoas empregadas (\% do Brasil: $2,3)$.

A Região Sudeste está composta pelo Polo de São Paulo formado pelas cidades de Franca, Birigui, Jaú e Santa Cruz do Rio Pardo, sendo Birigui a maior produtora nacional de calçados infantis; o Polo do Estado do Rio de Janeiro, ainda em formação por arranjos produtivos locais, com proposições às micro e pequenas empresas das cidades de Belford Roxo, Duque de Caxias, Rio Claro, São Gonçalo/Niterói, Região Serrana e Rio de Janeiro (capital); e os Polos Calçadistas do Estado de Minas Gerais representados pelas cidades de Nova Serrana, Belo Horizonte e Uberlândia.

A Região Nordeste é composta pelo Polo Calçadista do Estado da Bahia, distribuído nas regiões de Feira de Santana, Alagoinhas, Cruz das Almas, Itabuna, Vitória da Conquista e Ilhéus. Em torno de 39.337 trabalhadores (\% do Brasil: 11,3) atuam nas 104 empresas bahianas (\% do Brasil: 1,3), que produzem anualmente 43 milhões de pares de calçados; o Polo Calçadista do Ceará é o de Cariri, formado pelas cidades de Juazeiro do Norte, Crato e Barbalha, especializado na fabricação de sapatos de plástico ou borracha, sendo o terceiro maior polo calçadista do Brasil e de posição geográfica privilegiada para exportação.

Os Polos sediam 294 empresas fabricantes (\% do Brasil: 3,6), com um número de empregados de 63.562 pessoas (\% do Brasil: 18,2); e os Polos mais recentes, do Estado da Paraíba e Rio de Janeiro, um dos mais recentes polos de calçados do Brasil, possuem 112 empresas fabricantes (\% do Brasil: 1,4) com um total de 13.744 trabalhadores contratados (\% do Brasil: 3,9).

A Região Centro-Oeste possui o Polo do Estado de Goiás, também em formação, sendo estruturado como APL, composto por Empresas localizadas na cidade de Goianira, especializado em fabricar calçados em couro, um material em abundância local, por ser uma região responsável por $35 \%$ do rebanho bovino brasileiro.

A Região Norte, região brasileira que não se configura como Polo Calçadista, possui 21 empresas fabricantes que no ano de 2015 produziram 672.000 pares de calçados. 
Assim, tanto a demanda nacional quanto a demanda por municípios prioritários, seguirão uma definição de local para implantação do sistema levando em consideração a relação entre:

1) a oferta (em mão de obra e matéria-prima);

2) demanda de produção (no. de alunos matriculados).

3) capacidade de customização do desenvolvimento tecnológico realizado por APL's, definida pela participação de instituições de ciência e tecnologia.

A necessidade se dá porque cada região do Brasil se difere em características ambientais e culturais, impactando diretamente nos fatores de cada componente do produto. E como o sistema conta com o equilíbrio funcional da formação de capital social local de um APL, é proposto que cada local seja definido por uma combinação entre APL's capazes de serem responsáveis pelo desenvolvimento tecnológico personalizado ao seu território e ao mais próximo geograficamente que necessita de ajuda.

4) existem 35 empresas fabricantes de solados para calçados esportivos localizadas em cada estado do Brasil (ASSINTECAL, 2015), produzindo solados esportivos com os seguintes insumos, por ordem dos mais usados: borracha, poliuretano (PU), poliuretano termoplástico (TPU), policloreto de vinila (PVC); borracha termoplástica de estireno/butadieno (TR), Etileno Acetato de Vinila (EVA) e couro. O ranking do gráfico está relacionado com a propriedade do material para a função do produto (ASSINTECAL, 2014).

A correlação da distribuição de empresas fabricantes de solas no país, com os lotes de fornecimento de uniformes, definido pelo estudo da FGV (2010) para o FNDE e o número de alunos matriculados por região permite identificar o nível de combinação entre territórios fabricantes de sola com os territórios que estarão implantando o sistema e a sua cadeia de suprimentos (figura 41). 


\begin{tabular}{|c|c|c|c|}
\hline \multicolumn{4}{|c|}{$\mathbf{N}^{0 .}$ de alunos matriculados ensino fundamental $=10.749 .421$} \\
\hline $\begin{array}{l}\text { №. de lotes } \\
\text { definidos FGV } \\
(2010)\end{array}$ & \multicolumn{2}{|c|}{$\begin{array}{l}\text { №. de alunos matriculados por } \\
\text { estados de cada lote }\end{array}$} & Distribuição de solas \\
\hline 10. Lote & $\begin{array}{l}A C=59.722 \\
A M=286.685\end{array}$ & $\begin{array}{l}\mathrm{RR}=36.723 \\
\mathrm{PA}=547.283 \\
\mathrm{AP}=54.302\end{array}$ & $\begin{array}{l}\text { MG } 4 \text { = PA; RR; AP } \\
\text { RS } 16 \text { = AC; AM; }\end{array}$ \\
\hline $2^{\circ}$. Lote & $\begin{array}{l}\mathrm{RO}=106.682 \\
\mathrm{MT}=179.450 \\
\mathrm{TO}=869\end{array}$ & $\begin{array}{l}M A=502.251 \\
P I=199.475\end{array}$ & $\begin{array}{l}\text { RS } 16 \text { = RO; MS; } \\
\text { SC } 4 \text { = TO; MT; } \\
\text { MG } 4 \text { = MA; PI. }\end{array}$ \\
\hline $3^{\circ}$. Lote & $\begin{array}{l}\mathrm{CE}=485.633 \\
\mathrm{RN}=173.996\end{array}$ & $\mathrm{~PB}=215.699$ & SP 11 = CE; RN; PB. \\
\hline $4^{\circ}$. Lote & $\begin{aligned} P E & =490.309 \\
A L & =207.545\end{aligned}$ & $\mathrm{SE}=125.276$ & SP 11 = CE; RN; PB. \\
\hline $5^{\circ}$. Lote & $\mathrm{BA}=866.645$ & & \multirow{4}{*}{ Sem fábricas de solados } \\
\hline $6^{\circ}$. Lote & $\begin{array}{l}M G=1.169 .297 \\
E S=194.439\end{array}$ & $\mathrm{RJ}=707.273$ & \\
\hline $7^{\circ}$. Lote & $\mathrm{SP}=2.030 .009$ & & \\
\hline $8^{\circ}$. Lote & $\begin{array}{l}G O=319.391 \\
D F=133.242 \\
M S=153.051\end{array}$ & $\begin{array}{l}P R=821 \\
S C=291.457 \\
R S=530.865\end{array}$ & \\
\hline
\end{tabular}

Figura 41- Distribuição de fabricantes de sola por lotes de fornecimento do uniforme escolar definido pela FGV ao FNDE (2010).

Este indicador se refere à necessidade de desenvolvimento tecnológico para fabricação de solados escolares, considerando satisfazer as especificações técnicas do produto, orientadas pelos órgãos de fiscalização, como ABNT - Associação Brasileira de Normas Técnicas e INMETRO - Instituto Nacional de Metrologia. Orientações estas que fornecem parâmetros de conforto e segurança no uso do produto (fatores funcionais). Os fatores relacionados à dimensão ambiental e ergonomia do processo foram considerados no método em design para projetação do calçado (Ecodesign) e no modelo de fabricação do produto (Ecologia industrial).

No cadastro de Arranjos produtivos locais do Observatório Brasileiro de Arranjos produtivos locais (OBAPL), estão cadastrados 15 APL's do calçado no setor produtivo "Calçados", sendo eles: calçados do Cariri de Juazeiro do Norte; Calçados de Goiânia e Goianira; Calçados de Segurança de Guaxupé; Calçados de São João Batista; Calçados do Centro-oeste de Minas; Calçados e Acessórios de Belford Roxo e Duque de Caxias; Calçados e Bolsas da Região Metropolitana de 
Belo Horizonte; Calçados Femininos de Jaú, Calçados infantis de Birigui e Calçados Masculinos de Franca.

Foi identificada a ausência do mais importante APL do Calçado, o do Vale do Rio dos Sinos na lista de APL's do OBAPL. Nesse sentido, a pesquisadora contatou a ABICALÇADOS, por telefone e via email, para perguntar sobre esta ausência, e a entidade respondeu, por carta:

[...] não temos conhecimento de um APL formalizado em alguma instância governamental. O setor calçadista no Vale dos Sinos acabou se formando historicamente por conjunturas e não por um arranjo planejado.

Desta forma, há possibilidades de outros APL's, formados historicamente pela interação natural entre os agentes sociais do território, não estarem listados, cabendo uma investigação no território onde demonstrar necessidade de implementação do sistema.

Os dados mostram que o território brasileiro possui capacidade de oferta em mão de obra e insumos para o sistema de produção do calçado escolar, desde que seja realizada uma parceria entre territórios mais próximos geograficamente possíveis, especialmente no que se refere à cadeia de suprimentos do solado, por que: são poucas as empresas fabricantes e é um componente que demanda desenvolvimento e inovação tecnológica para atender os requisitos obrigatórios do método em design do sistema modelo.

\subsection{2.}

Trabalhadores artesanais da confecção de calçados e artefatos de couros e peles/Moda

Com a intenção de aproveitar a estrutura já instituída pelo MDIC de Arranjos Produtivos Locais e a motivação por parte do Plano Nacional de Cultura para que a cultura seja um vetor de desenvolvimento socioeconômico no Brasil, esta proposta considera o sapateiro local uma mão de obra de concepção cultural à manufatura do calçado escolar.

A profissão de sapateiro veio perdendo sua função prática, e não simbólica, desde que o processo de desenvolvimento tecnológico alcançou a indústria calçadista, tanto em nível mundial como nacional, com ofertas de calçados no mercado brasileiro, não mais fabricados por montagem artesanal e compostos pelo material couro para o cabedal, sola e demais componentes do calçado, e sim por materiais de fabricação padronizada e de larga escala produtiva como os solados 
de borrachas (elastômeros) e de base plástica como o PU, PVC e TPU. Componentes que definem processos de fabricação mais ágeis, de menos tempo e que conferem ao calçado uma obsolescência programada de três meses, em média, não permitindo ao consumidor uma redução de custo e benefício com sua manutenção em sapateiros locais, o que define que o descarte do produto terá destino no lixo doméstico e nos aterros sanitários.

Nesse sentido, foi realizada uma estratificação para identificar se os artesãos utilitários ou sapateiros locais teriam capacidade de produção destes calçados nos territórios do Brasil. A referencia foi a combinação entre os indicadores nacionais do número de trabalhadores artesanais da confecção de calçados e artefatos de couros e peles, de cada estado do Brasil, cadastrados no sistema de economia criativa do Brasil (APL's economia criativa, segmento MODA) (FIRJAN, 2013) e o número de alunos matriculados na rede pública de ensino fundamental de cada estado do Brasil (INEP, 2015) (Figura 42). 


\begin{tabular}{|c|c|c|c|c|c|c|}
\hline $\begin{array}{l}\mathrm{N}^{\mathrm{o}} \text { de ar } \\
\text { do Brasi }\end{array}$ & $\begin{array}{l}\text { tesãos por estados } \\
\text { I (economia criativa) }\end{array}$ & $\begin{array}{l}\mathrm{N}^{0} \text { de crianças } \mathrm{m} \\
\text { no ensino fundan } \\
\text { rede pública do } \mathrm{B} \\
\text { estado) }\end{array}$ & $\begin{array}{l}\text { atriculadas } \\
\text { ental da } \\
\text { rasil (por }\end{array}$ & $\begin{array}{l}\mathrm{N}^{\circ} \text {. de pares } \\
\text { de calçados } \\
\text { por } \mathrm{n}^{\circ} \text { de } \\
\text { artesãos ( } \mathrm{n}^{\circ} \text {. } \\
\text { de crianças } \\
\text { por } \\
\text { artesão). }\end{array}$ & $\begin{array}{l}\mathrm{N}^{0 .} \text { de } \\
\text { pares para } \\
\text { fabricar, } \\
\text { por dia, } \\
\text { durante } 90 \\
\text { dias }^{31} \text {, } \\
\text { trabalhando } \\
6 \text { horas por } \\
\text { dia. }\end{array}$ & $\begin{array}{l}\mathrm{N}^{\circ} \text { de } \\
\text { pares por } \\
\text { hora, } \\
\text { trabalhando } \\
6 \mathrm{~h} \text {, } \\
\text { durante } 90 \\
\text { dias. }\end{array}$ \\
\hline 36 & ACRE & ACRE & 119.444 & 3.318 & 9 & 2 \\
\hline 35 & ALAGOAS & ALAGOAS & 415090 & 11.860 & 33 & 5 \\
\hline 19 & AMAPA & AMAPA & 107.054 & 5.634 & 16 & 3 \\
\hline 45 & AMAZONAS & AMAZONAS & 573.370 & 12.742 & 35 & 6 \\
\hline 2.219 & BAHIA & BAHIA & 1733290 & 781 & 2 & 0 \\
\hline 1.657 & CEARA & CEARÃ & 971.266 & 586 & 2 & 0 \\
\hline 93 & $\begin{array}{l}\text { DISTRITO } \\
\text { FEDERAL }\end{array}$ & & & - & - & - \\
\hline 95 & ESPIRITO SANTO & $\begin{array}{l}\text { ESPIRITO } \\
\text { SANTO }\end{array}$ & 388878 & 4.093 & 11 & 2 \\
\hline 394 & GOIAS & GOIAS & 638.782 & 1.621 & 5 & 1 \\
\hline 39 & MARANHAO & MARANHAO & 1004502 & 25.756 & 72 & 12 \\
\hline 52 & MATO GROSSO & $\begin{array}{l}\text { MATO } \\
\text { GROSSO }\end{array}$ & 358.900 & 6.902 & 19 & 3 \\
\hline 93 & $\begin{array}{l}\text { MATO GROSSO } \\
\text { DO SUL }\end{array}$ & $\begin{array}{l}\text { MATO } \\
\text { GROSSO DO } \\
\text { SUL }\end{array}$ & 358.900 & 3.859 & 11 & 2 \\
\hline 2.123 & MINAS GERAIS & MINAS GERAIS & 2.338 .594 & 1.102 & 3 & 1 \\
\hline 41 & PARA & PARA & 1094566 & 26.697 & 74 & 12 \\
\hline 192 & PARAIBA & PARAIBA & 431398 & 2.247 & 6 & 1 \\
\hline 355 & PARANA & PARANA & 1163628 & 3.278 & 9 & 2 \\
\hline 169 & PERNAMBUCO & PERNAMBUCO & 980618 & 5.802 & 16 & 3 \\
\hline 35 & PIAUI & PIAUI & 398950 & 11.399 & 32 & 5 \\
\hline 477 & RIO DE JANEIRO & $\begin{array}{l}\text { RIO DE } \\
\text { JANEIRO }\end{array}$ & 1414546 & 2.966 & 8 & 1 \\
\hline 30 & $\begin{array}{l}\text { RIO GRANDE DO } \\
\text { NORTE }\end{array}$ & $\begin{array}{l}\text { RIO GRANDE } \\
\text { DO NORTE }\end{array}$ & 347.992 & 11.600 & 32 & 5 \\
\hline 2.588 & $\begin{array}{l}\text { RIO GRANDE DO } \\
\text { SUL }\end{array}$ & $\begin{array}{l}\text { RIO GRANDE } \\
\text { DO SUL }\end{array}$ & 1061730 & 410 & 1 & 0 \\
\hline 21 & RONDONIA & RONDONIA & 213.364 & 10.160 & 28 & 5 \\
\hline- & \begin{tabular}{|l} 
RORAIMA \\
\end{tabular} & RORAIMA & 73.446 & - & - & - \\
\hline 471 & \begin{tabular}{|l|} 
SANTA \\
CATARINA \\
\end{tabular} & $\begin{array}{l}\text { SANTA } \\
\text { CATARINA }\end{array}$ & 582914 & 1.238 & 3 & 1 \\
\hline 7.387 & SÃO PAULO & SÃO PAULO & 4.060 .018 & 550 & 2 & 0 \\
\hline 6 & SERGIPE & SERGIPE & 250.552 & 41.759 & 116 & 19 \\
\hline 12 & TOCANTINS & TOCANTINS & 1738 & 145 & 0 & 0 \\
\hline
\end{tabular}

Figura 42 - Capacidade para fabricação artesanal do calçado no Brasil

A coluna que mostra o número de pares a serem fabricados por hora indica a necessidade de cooperação, entre artesãos de regiões próximas, para equilibrar a

${ }^{31}$ Período de 90 dias: são os 3 meses (90 dias) para fabricação e entrega deste produto nas escolas, sabendo-se que outubro inicia o período das matrículas do ano vindouro a fevereiro quando inicia as aulas. 
quantidade de pares fabricados por cada artesão, respeitando a adaptação das condições de trabalho às características psicofisiológicas dos artesãos, e assim proporcionar um máximo de conforto, segurança e desempenho eficiente em relação à atividade realizada (Ministério do trabalho, 1983).

Esta realidade pode ser percebida na fala de sapateiros entrevistados na cidade de Novo Hamburgo, quando citam que as fabriquetas de calçados podem fazer a manufatura e eles a manutenção, descrita no item 4.6.2 deste capitulo. Contudo, se o planejamento de produção tiver um cronograma de fabricação de um semestre para outro, a capacidade produtiva e a oportunidade dos sapateiros participarem da manufatura se amplia, sem que eles tenham que deixar de fazer seus consertos tradicionais, principalmente nos territórios que precisam gerar trabalho e renda. Nesse sentido, pode-se estimar que a produção pode ser dividida (50\%) entre artesãos locais e MPE’́s fabricantes de calçados, que é mais do que a proporção de $30 \%$ concedida aos agricultores familiares para fornecimento de alimentos à merenda escolar (Figura 43).

\begin{tabular}{|c|c|c|c|c|c|}
\hline $\begin{array}{l}\text { Trabalh } \\
\text { Da Indú } \\
\text { Cadastr }\end{array}$ & $\begin{array}{l}\text { Iadores art } \\
\text { istria Criati } \\
\text { rados no s }\end{array}$ & $\begin{array}{l}\text { esanais da confecção } \\
\text { iva do Brasil } \\
\text { egmento: MODA }\end{array}$ & de calç & s e artefat & os de couros e peles \\
\hline $\begin{array}{l}\mathbf{N}^{\circ} . \\
\text { Ordem }\end{array}$ & \begin{tabular}{|l}
$N^{\circ}$. de \\
artesãos
\end{tabular} & Estado & \begin{tabular}{|l|}
$\mathbf{N}^{\circ}$. \\
ordem
\end{tabular} & \begin{tabular}{|l}
$N^{\circ}$. de \\
artesãos
\end{tabular} & Estado \\
\hline 1 & 36 & ACRE & 14 & 355 & PARANA \\
\hline 2 & 19 & AMAPA & 15 & 169 & PERNAMBUCO \\
\hline 3 & 45 & AMAZONAS & 16 & 35 & PIAUI \\
\hline 4 & 2.219 & BAHIA & 17 & 477 & RIO DE JANEIRO \\
\hline 5 & 1.657 & CEARÁ & 18 & 30 & \begin{tabular}{|l|} 
RIO GRANDE DO \\
NORTE
\end{tabular} \\
\hline 6 & 93 & DISTRITO FEDERAL & 19 & 2.588 & $\begin{array}{l}\text { RIO GRANDE DO } \\
\text { SUL }\end{array}$ \\
\hline 7 & 95 & ESPIRITO SANTO & 20 & 21 & RONDONIA \\
\hline 8 & 394 & GOIAS & 21 & 0 & RORAIMA \\
\hline 9 & 39 & MARANHÃO & 22 & 471 & SANTA CATARINA \\
\hline 10 & 52 & MATO GROSSO & 23 & 7.387 & SÃO PAULO \\
\hline 11 & 93 & $\begin{array}{l}\text { MATO GROSSO DO } \\
\text { SUL }\end{array}$ & 24 & 6 & SERGIPE \\
\hline 12 & 41 & PARA & 25 & 12 & \\
\hline 13 & 192 & PARAIIBA & 20 & 12 & IOCANIIN \\
\hline
\end{tabular}

Figura 43 - Consulta no Mapeamento da indústria criativa sobre trabalhadores artesanais da confecção de calçados (Firjan, 2014). 
Entretanto, ao pesquisar o número de APL's do Calçado do Brasil, foi identificado que no Mapeamento da Indústria Criativa no Brasil, eles estão alocados dentro do segmento de moda e são reconhecidos como: Trabalhadores artesanais da confecção de calçados e artefatos de couros e peles/Moda.

Assim sendo, foram solicitadas informações à FIRJAN sobre: 1) os critérios (indicadores) que os enquadram na categoria de artesanais; e 2) se neste grupo de profissionais estariam incluídos os profissionais atuantes nos APL's do Calçado, cadastrados pelo OBAPL, dentro do setor produtivo Calçado. A informação é necessária para identificar se esta mão de obra classificada como artesanal é de artesanato utilitário que podemos considerar como recurso ao sistema de produção para manufatura do calçado escolar no Rio de Janeiro, sem que se esteja promovendo qualquer intervenção no artesanato das pessoas em seus territórios e vidas.

A FIRJAN não respondeu, mas foram válidas, para a pesquisa, as informações que os agentes sociais de Duque de Caxias forneceram sobre as características dos profissionais que atuam no APL Lote XV, os sapateiros ou casqueteiros, como o Sr. Avelino respondeu: foram sapateiros a vida toda e com a formação do APL pretendem se profissionalizar mais. Agrega-se a isto, o que os sapateiros de novo Hamburgo informaram sobre sua rotina de trabalho.

\subsection{3.}

Oferta territorial de Novo Hamburgo: disponibilidade de mão de obra e insumos

De acordo com a formação do capital social do sistema-piloto de Novo Hamburgo, estão disponíveis como mão de obra local os artesãos manuais que participam das oficinas da Incubadora Popular da Prefeitura e as Fabriquetas de bairro ou MPE’s localizadas no município.

Oficialmente, o mural de economia criativa mostra que existem 18.650 trabalhadores artesanais da confecção de calçados e artefatos de couros e peles/Moda, o que não corresponde às informações dos agentes sociais do sistema-piloto, para eles: este número contem todos os profissionais ou parte deles atuantes nas empresas de calçados, assumidos pela FIRJAN como artesãos. Como a FIRJAN não respondeu a solicitação de informação sobre o assunto não podemos apresentar dados concretos, apenas o que foi identificado (Figura 44). 

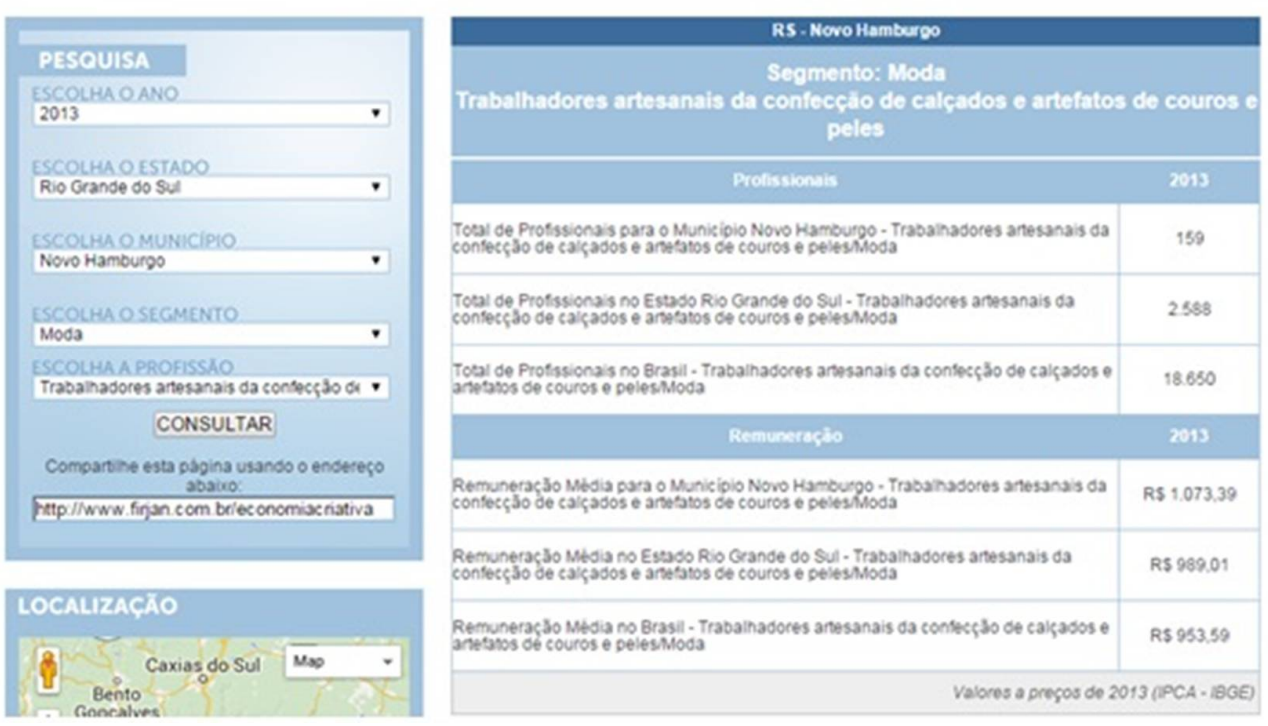

Figura 44- No. de Trabalhadores artesanais da confecção de calçados e artefatos de couros e peles da cidade de Novo Hamburgo (FIRJAN, 2013).

Quanto à disponibilidade de insumos, como a cidade de Novo Hamburgo faz parte do grupo de municípios do Polo calçadista do Vale do Rio dos Sinos e formada por um cluster de empresas de atividade relacionada, há empresas de componentes para calçados e desenvolvimento de inovações tecnológicas em quantidade suficiente para atender, com novos componentes ou com seus resíduos, desde que selecionados anteriormente. A Incubadora Popular da Prefeitura de Novo Hamburgo supre as oficinas artesanais que acontecem no espaço com estes resíduos.

Contudo, a ASSINTECAL, como é um dos agentes do grupo social do sistema-piloto, apresentou-se como apoiadora na indicação de empresas para a formação da cadeia de suprimentos. Como citado pelos agentes sociais:

[...] em novo Hamburgo não tem mistério, há opção, é só seguir as orientações do projeto para achar o componente certo. Mas vai ficar difícil achar solado que vire plantinha tchê.

O solado é o componente que mais demandou comentário entre o grupo social produtivo. Ainda sem receberem a ficha técnica com os requisitos obrigatórios para o projeto do produto.

Para o cabedal, o grupo citou utilizar: resíduos de tecido; tecido e linhas de lá fabricadas pelas artesãs de Lomba Grande (zona rural de $\mathrm{NH}$ ); linha de ponto celeiro para unir as partes do calçado, inclusive cabedal e solado; couro raspa e camurça, curtido ao vegetal, de classificação não aceita pelo mercado tradicional 
e, mas com propriedade para tênis escolar e a Cáritas de Novo Hamburgo, ofereceu os brechós que funcionam nas igrejas locais.

\subsection{4.}

\section{Capacidade de produção do calçado no território de Novo Hamburgo}

Segundo informações de um sapateiro local, um tênis pode ser manufaturado, de forma multifuncional (célula de produção) sem divisão do trabalho, por uma pessoa em 30 minutos.

Sabendo-se que de outubro (início das matrículas do ano vindouro) a fevereiro (início das aulas) existem 3 meses (90 dias) para fabricação e entrega deste produto nas escolas, a demanda de 23.426 alunos, ou pares de calçados, poderia ser atendida/manufaturada por 22 pessoas. Este cálculo poderá ser diferente se considerarmos produzir os calçados de um semestre para outro, para aumentar o tempo de elaboração do Plano-mestre e planejamento operacional da produção.

Assim, um município como Novo Hamburgo (cidade do calçado), reconhecido como o Polo e cluster calçadista mais importante do Brasil ${ }^{32}$, tem capacidade produtiva para atender sua autodemanda de forma personalizada, gerando trabalho, renda e respeitando os requisitos obrigatórios de produto e processo do método em design do modelo do sistema.

\subsection{5.}

Oferta territorial dos municípios de Belford Roxo e Duque de Caxias, no município do Rio de Janeiro: mão de obra e insumos

A oferta de mão de obra para o fornecimento do calçado no município do Rio de Janeiro pode ter fonte nas duas indicações de APL do Calçado do Rio de Janeiro (OBAPL, 2015), que estão localizados nos municípios de Belford Roxo e Duque de Caixas, no bairro do Lote XV e nas indicações do Mural de Economia Criativa sobre os trabalhadores artesãos da Confecção de calçados e artefatos de couros e peles (FIRJAN, 2013).

Conforme informações da SEDEIS/RJ:

O APL do Lote XV é formado de MPE's, cujo processo produtivo ainda é artesanal. $\mathrm{O}$ polo encontra-se em expansão e a maioria dos empresários vem

32 Polo calçadista mais importante do Brasil - os P\&D's das empresas ficam localizados em Novo Hamburgo e a produção em outras regiões do Brasil, como Nordeste, ou em outros países, como a China. Motivo: custo de produção e estratégia de logística de exportação. 
buscando a formalização e a regularização de suas atividades. As lideranças são atuantes e estão sempre apresentando novos projetos, dentre estes a criação de uma Fábrica Escola. A área do Lote XV, onde se localiza a maioria das empresas, é muito pobre e carente de empregos. Recentemente, instalou-se em Belford Roxo a filial de uma empresa de calçados do sul, atraída pelo expressivo mercado consumidor.

O Mapa da Economia criativa mostra que 477 profissionais no Estado do Rio de Janeiro, trabalhadores da Confecção de calçados e artefatos de couros e peles, cadastrados no segmento de moda, da economia criativa, são reconhecidos como artesãos (figura 45).
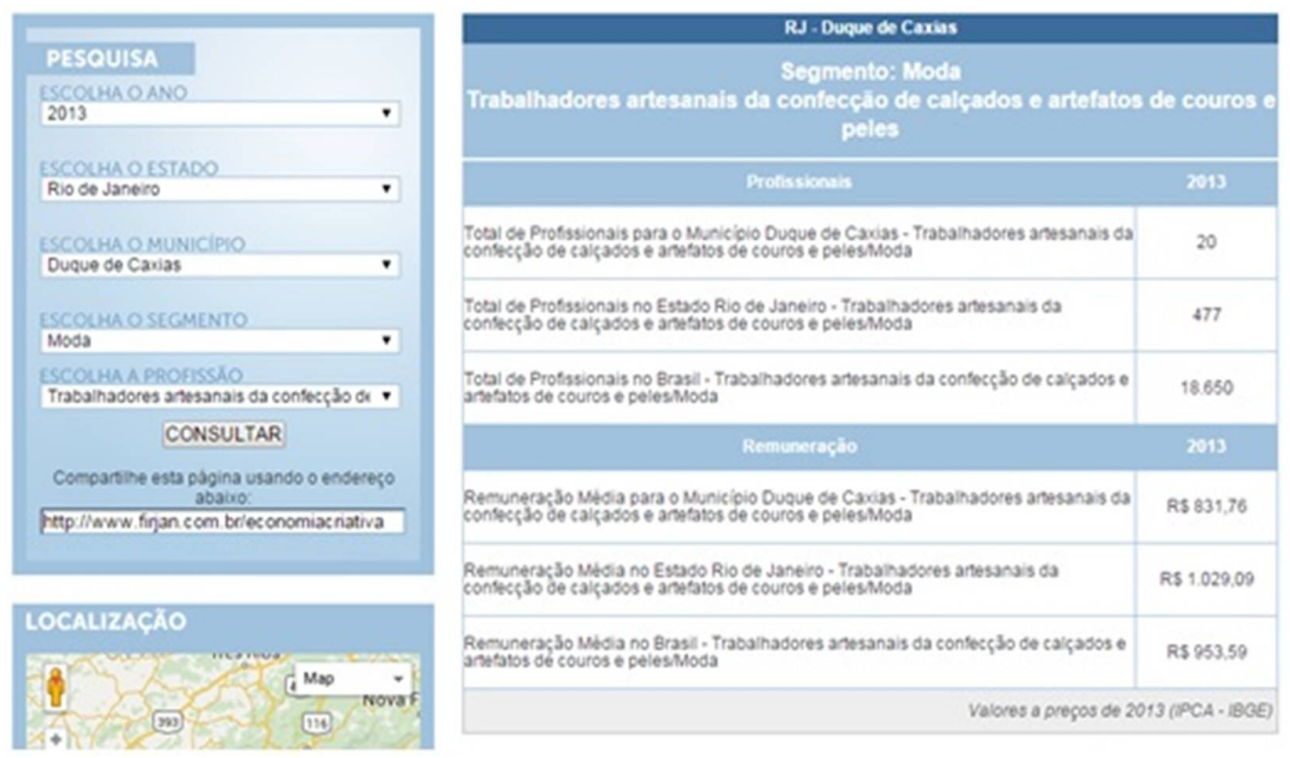

Figura 45 - No. de Trabalhadores artesanais da confecção de calçados e artefatos de couros e peles/Moda da cidade de Duque de Caxias (FIRJAN, 2013).

As informações concedidas pelo Sr. Avelino e pelo representante da Secretaria de Desenvolvimento econômico de Duque de Caxias sobre a cadeia de suprimentos das empresas de Duque de Caxias foi:

Os materiais são tecidos (na maioria), sintéticos, tiras para sandálias e couro. Mas são em quantidade pouca porque fabricamos muitas sandálias. Os solados a gente compra nos revendedores. Para desenvolver materiais novos é muito caro, por isso precisamos do APL para formar um grupo e melhorar esses problemas. Mas se for para fabricar a gente se vira e consegue o material correto. Temos vontade de crescer e acompanhar o mercado. Locais de venda estão no bairro da Penha (couro), Tecidos em Duque de Caxias, Engenho Novo, e demais acessórios em Madureira e alguma coisa no bairro de São Gonçalo, em Niterói. 
Alguns quando podem compram de Minas Gerais ou São Paulo que é mais perto e tem muita opção.

A informação da Secretaria de desenvolvimento econômico de Duque de Caxias informou que:

eles compram em Madureira. Tem muita loja de tecido, couro e materiais para calçados. Do outro lado da linha, indo para Praça Seca. Madureira tem opções. Na Penha tem revendedores de couro, mas não tem muitas opções. Poderia ter empresas fabricantes no município ou bons revendedores com preços mais atraentes, demanda tem pra isso. Porque se empresa gaúcha, fabricante de calçados, veio pra cá é porque tem mercado.

\subsection{6. \\ Capacidade de produção do calçado no território de Duque de Caxias e Belford Roxo}

Tomando como referência as informações coletadas para calcular a capacidade produtiva local pela demanda dos dois municípios, mesmo que Belford Roxo não tenha fornecido dados oficiais, a representante da Secretaria de educação informou, via telefone, que a cidade distribui o calçado escolar para todas as escolas, portanto demonstra oportunidade ao sistema local. Desta forma assumindo que:

Um tênis pode ser manufaturado, de forma multifuncional (célula de produção) sem divisão do trabalho, por uma pessoa em 30 minutos (informação confirmada, por um sapateiro da COOPFARJ).

Sabendo-se que de outubro (início das matrículas do ano vindouro) a fevereiro (início das aulas) e que teríamos 3 meses para fabricação e entrega deste produto nas escolas, a demanda de 93.927 alunos, ou pares de calçados, seria fabricado por 88 pessoas.

A cooperativa de fabricantes de calçados - COOPFARJ, do município de Duque de Caixas, composta por 80 empresas, localizadas no bairro Lote XV, demonstra ter capacidade produtiva para atender a demanda dos dois municípios.

O número de pessoas necessárias para fabricar a demanda de calçados dos territórios, assumindo que 1 pessoa, em 3 meses, produz 1056 pares, poderia ser suprido por um percentual de pessoas vulneráveis vivendo em cada um dos territórios (respeitando a condição de cada indivíduo), fazendo com que o sistema já estivesse contribuindo com a geração de renda, trabalho e desenvolvimento humano nestes territórios. 
Em conclusão, o Brasil e seus territórios, incluindo os municípios de Novo Hamburgo e Duque de Caxias, possuem capacidade produtiva para manufatura considerando como mão de obra artesãos utilitários, sejam eles os reconhecidos como sapateiros, casqueteiros, manuais ou trabalhadores artesanais da confecção de calçados e artefatos de couros e pele, principalmente se pertencem a territórios com IDHM baixo, denotando prioridade de atendimento. As únicas modalidades de artesanato que não gostaríamos de considerar seriam os conceituais e tradicionais, contudo, se for uma opção das pessoas, serão bem vindas, mas não o grupo social produtivo intervir em suas obras ou fazeres. Da mesma forma aos demais artesãos do artesanato utilitário, a proposta é de trabalho participativo e conhecimentos compartilhados.

\section{8.}

Cadeia de suprimentos do sistema de produção (Fase 3)

Para identificação das alternativas de fabricantes a comporem a cadeia de suprimentos para produção do calçado escolar, foi feita investigação no CATMAT. Foram identificados componentes de solados para calçados (figura 46) cadastrados no grupo de itens "não sustentáveis", o que permite assumir que a opção de compra de solado ou demais componentes para o calçado escolar é aceita pelos instrumentos da administração pública, conforme proposto pelo modelo do sistema. Outro bem que poderá ser adquirido, que foi identificado é "molde de solado", ou seja, também é possível solicitar a compra de matrizes de injeção para fabricação do solado, para não ocorrer limitações quanto ao atendimento dos fatores de produto, conforme a situação apresentada no município de Novo Hamburgo. 


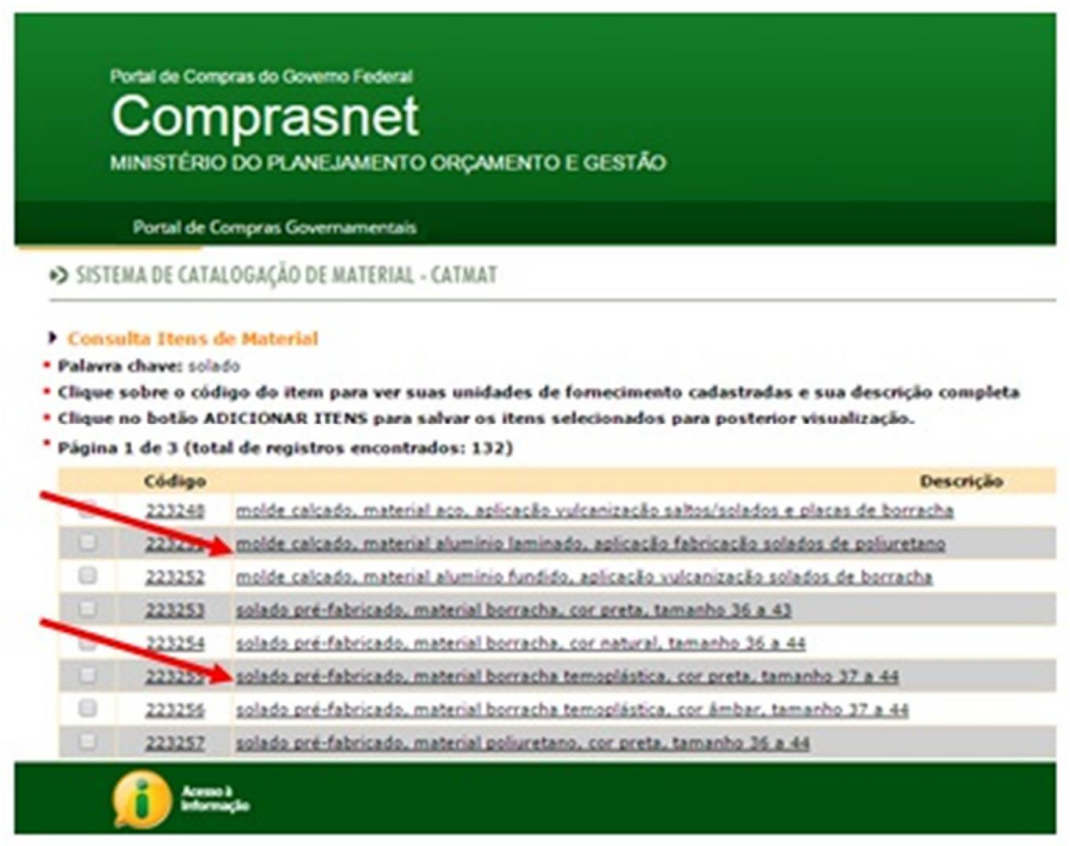

Figura 46 - Resultado da busca por "solado", sem a opção produto sustentável, no sistema de catalogação de material do portal de compras governamentais CATMAT.

Não foram encontrados calçados escolares cadastrados no sistema, mas foram identificados tênis, sem a especificação para uso escolar. Contudo, não foram identificados calçados, calçados escolares e tênis, na modalidade "item sustentável” no CATMAT.

\section{9.}

Método em design para projeto do calçado escolar (Fase 3)

O projeto do produto calçado escolar foi desenvolvido conforme as orientações do método em design, com base nas informações coletadas entre 2008 e 2015, a partir de uma amostra extraída das populações de cada ator social envolvido na problemática do calçado escolar. Entende-se por atores sociais as escolas de bairro (municipais e estaduais), as Secretarias de Educação (estaduais e municipais), professores, alunos matriculados nas escolas e seus pais, o Fundo Nacional de Desenvolvimento da Educação - FNDE e a Associação Brasileira das Indústrias de Calçados do Brasil - ABICALÇADOS.

A definição da amostra foi não probabilística, do tipo "a que tivemos acesso". Nos primeiros contatos realizados com os atores, principalmente aqueles vinculados as instituições públicas e as empresariais, foi percebido um desconforto das pessoas, em fornecer dados sobre o assunto, bem como permitir 
acesso oficial, junto às crianças matriculadas nas escolas, pais dos alunos e empresas fabricantes de calçados.

O primeiro passo foi contatar escolas próximas à residência da pesquisadora, onde as pessoas já a conheciam, especialmente na escola onde sua filha estava matriculada, e as escolas onde amigos poderiam indicar os propósitos da pesquisa à Diretora da Escola. O acesso aos alunos partia desses contatos que iam se fortalecendo, de indicação a indicação, bem como com as mães dos alunos.

Apesar da experiência negativa com as Secretarias de estado e município, com relação ao acesso às informações, foi contatado o FNDE, localizado em Brasília. Surpreendentemente, não só aceitaram repassar as informações, como esclareceram que tinham muita dificuldade de obter dados técnicos, funcionais, de produção e estéticos do "tênis escolar". Desta forma, fizeram um convite à pesquisadora para participar, como designer, junto às instituições como o SENAI - CT Calçados, responsáveis pelos ensaios das amostras desenvolvidas por empresas participantes do pregão nacional. A participação até hoje acontece, o que possibilita o acesso às informações atualizadas para esta pesquisa.

Quanto a ABICALÇADOS, o fato de a pesquisadora ser moradora da cidade de Novo Hamburgo e já tendo atuado como designer no setor calçadista, facilitou o acesso à Entidade, contudo também foi identificado um desconforto ao tratar do assunto "pregão do calçado escolar".

Tendo conhecimento da dificuldade de acesso às escolas, optou-se por identificar pessoas do convívio da pesquisadora que tivessem contato com escolas para indicar a pesquisa e permitir seu acesso. Desta forma, foram contatadas escolas de Centros Urbanos, como no Rio de Janeiro, São Paulo e Porto Alegre e em Novo Hamburgo, também nas periferias ou zonas rurais. O interesse era descobrir peculiaridades do ambiente urbano em relação aos ambientes periféricos, rural e subúrbios. A cidade de Novo Hamburgo tem uma peculiaridade em relação ao calçado, pois sua economia depende exclusivamente deste produto, e muitas crianças ainda trabalham no sistema produtivo do calçado. Elas acompanham o cotidiano da mãe, que trabalha em casa para os ateliês de costura ou preparação do calçado (que dizem: graças a Deus que existe este trabalho, preciso cuidar das crias).

Foi obtido acesso as escolas, no Estado do Rio Grande do Sul, nas cidades de Novo Hamburgo (distante $47 \mathrm{~km}$ da Capital) e Porto Alegre (Capital), bem 
como em escolas da cidade de São Paulo, localizada em uma comunidade de baixa renda do Bairro Interlagos, e do Rio de Janeiro, no bairro de Bento Ribeiro (subúrbio - distante $80 \mathrm{~km}$ do Centro do RJ), bairro natal da pesquisadora e residência atual de sua família.

O levantamento de dados iniciou com as escolas, seguindo um roteiro de entrevistas composto por três perguntas: vocês distribuem uniformes escolares? Por que sim ou e por que não? Se sim, o que distribuem?

Durante a visita aos ambientes escolares, foram contatados outros atores sociais além dos técnicos administrativos, para falar sobre o uniforme escolar, especialmente sobre o calçado.

\subsection{1.}

\section{Resultados do levantamento junto às escolas (diretores e professores)}

Alguns diretores de escolas responderam que a distribuição dos calçados: dependia da prefeitura de cada cidade, e que tinham o conhecimento de que algumas escolas distribuíam, mas muitas outras não, sem saber explicar o motivo. Nenhuma das entrevistadas disse que distribuía.

As professoras demonstraram ser favoráveis ao uso do uniforme, apesar de saberem que alguns podem adquirir e outros não. Contudo explicaram que as crianças, hoje em dia, já são tão rebeldes, que se houver a permissão de não usar o uniforme, não se consegue dar aula, parece que elas ficam mais incontroláveis em sala. Dizem elas que: o uniforme ajuda a disciplinar os alunos. Sem o uniforme a sala de aula mais parece um ponto de encontro da galera, com conversas inflamadas e desfiles de moda.

$\mathrm{Na}$ opinião dos professores e diretores de escola, o uniforme parece ter se transformado no escudo capaz de impedir os males da potencial violência no caminho entre a casa e a escola, principalmente em comunidades de alto risco, pela presença do tráfico de drogas.

As diretoras relataram a importância do uniforme, como identificação, para assegurar as crianças quando estão em ambientes externos da escola. Elas fizeram questão de citar que uma escola, no estado da Bahia, criou um uniforme com chip, permitindo a vigilância do aluno na frequência das aulas. E a dúvida delas era: mas como? Com que dinheiro fizeram isso? Porque essa nova tecnologia deve ser muito cara e quase inacessível. E a escola que distribui é pública. 
As diretoras falaram da não obrigatoriedade no uso: não há como exigir, caso não seja distribuído gratuitamente, se os pais não têm condições de comprar, principalmente os tênis, que são mais caros. Mas não há critérios por parte das instituições para o fornecimento do uniforme, tão pouco do tênis escolar. Nas escolas que prezam o uso do uniforme, o que normalmente acontece é um brechó, com doações dos próprios alunos e comunidade, o que permite a distribuição para os mais carentes.

Os brechós escolares são organizados por pais representantes, que coletam uniformes, já usados, e deixam à disposição na escola ou promovem feiras de trocas, entre eles mesmos, ou vendas a um custo (fixo para qualquer peça) bem abaixo do mercado. O montante arrecadado é usado em melhorias na escola, ou são revertidos para outra escola local com menor capacidade financeira de compra de uniformes.

Quanto à segunda pergunta: e os calçados escolares? As diretoras das escolas contatadas relataram que há poucos tênis nos brechós, porque eles se desgastam no período escolar, o que é ruim porque a compra de um novo par, sempre que necessário, fica muito caro.

Os relatos demonstram que os brechós, além de ser uma solução econômica interessante para todos os pais, principalmente aqueles que possuem mais de um filho na escola, proporcionam um reconhecimento de ensino e sensibilização à responsabilidade ambiental e social na comunidade. Falaram com orgulho que, na cidade de Porto Alegre, no estado do Rio Grande do Sul, estas iniciativas são divulgadas pelos jornais locais, os de grande circulação, como o Jornal Zero Hora (2013), como uma prática favorável à comunidade, independente de classe econômica:

Há cinco anos, a lojista Jurema Zanatta, 40 anos, passava por essa situação: no começo das aulas, tinha de se livrar dos uniformes escolares que os filhos usaram no ano anterior e comprar tudo novo. Mãe de Ana Luisa, três anos, e João Pedro, seis anos, Jurema se diz fã do brechó da escola: além de ser muito melhor financeiramente, é bom para educar nossos filhos sobre a importância da reciclagem para cuidar do nosso planeta. Desde que frequenta o brechó, há dois anos, a lojista já comprou e doou diversas peças. Somente na semana passada, Ana Luisa ganhou cinco uniformes reciclados, que exibe como se fossem novos (Jornal Zero Hora, 2013).

Os diretores e professores das escolas demonstraram ser interessante distribuir os uniformes escolares, o tênis principalmente, por ser um item muito caro e de gasto rápido, e os pais não possuem dinheiro para estar trocando sempre 
que o filho precisa. Mas admitem que antes do uniforme, as escolas têm outras necessidades mais básicas a serem supridas, como por exemplo, infraestrutura:

Conseguimos comprar, com o mutirão dos pais, todos os condicionadores de ar, tipo split, um para cada sala, mas agora não conseguimos usar, pois não conseguimos o novo relógio que suporta a carga de todos os aparelhos ligados ao mesmo tempo. O que seria contrapartida do governo. Ficamos na mesma (Diretora da Escola Estadual Otávio Rosa, na cidade de Novo Hamburgo, RS: escola que filha da pesquisadora estudou).

Algumas escolas distribuem o uniforme escolar, mas outras não, indicando ausência de critérios. Há disposição para iniciativas participativas, entre pais e escolas, para dar soluções alternativas. Mesmo com estas iniciativas, a contrapartida do Governo falha.

A análise do contexto social apresentou um ponto crítico: as professoras e a direção das escolas, localizadas em comunidades de alto risco, ficam entre a segurança dessas crianças por vigilância e a imposição do uso do uniforme escolar, sabendo que não podem fazê-lo, a menos que a escola o distribua gratuitamente. $\mathrm{O}$ uniforme realmente parece ter se transformado no escudo capaz de impedir os males da potencial violência no caminho entre a casa e a escola.

Quanto ao uniforme com chip, a Secretaria de Educação de Vitória da Conquista (Bahia) informou que a cidade foi a primeira a instalar chip em uniforme escolar (especificamente no escudo da escola aplicado na manga da camisa). A comunicação é feita para o celular dos pais quando o aluno passa pelo portão da escola (entrando ou saindo). Acreditam estar prezando pela segurança dos alunos e auxiliando os pais. Os pais também se posicionam satisfeitos com a solução tecnológica dizendo: com tanta violência precisamos ter certeza que nosso menino entrou na escola. A escola é pública, o uniforme é comprado pela prefeitura, mas não é similar ao tipo do kit montado pelo FNDE. O projeto foi abandonado, em 2013, por causa do custo bilionário de 1,1 bilhão de reais e pelo não funcionamento do chip com a lavagem e o uso da blusa.

As iniciativas dos brechós são soluções bem aceitas e realmente usadas pelos pais dos alunos. A pesquisadora participou, no período que sua filha estudava (até dezembro de 2014), levando todos os anos os uniformes usados do ano anterior e comprando outras peças. Mas tênis, realmente, nunca foram vistos no brechó da Escola Estadual Otávio Rosa, na cidade de Novo Hamburgo, conhecida como a cidade do calçado. 
Outro fator citado pelas mães foi que as crianças uniformizadas podem ser vigiadas pela comunidade local, porque no horário da escola algumas estão sempre trabalhando, e se os filhos estão gazeteando no horário da aula, alguém sempre avisa.

Uma das mães, gaúchas, relatou que o uniforme já salvou a vida do filho, quando os brigadianos (policiais militares) entraram na vila para dar uma batida: guri uniformizado não é ladrão, principalmente se estiver no horário de saída ou entrada da escola.

Uma das mães disse: essas crianças não têm querer, usam o que se tem. Por isso existe um uniforme que não precisa da marca da escola estampada, que é calça jeans, camiseta branca e tênis. Este fica mais fácil de conseguir e a escola autoriza o seu uso.

\subsection{2. \\ Resultados da Secretaria de Educação do Município de Duque de Caxias}

A Secretaria de Educação do Município de Duque de Caxias, através do departamento de infraestrutura da prefeitura, respondeu que distribui todos os anos o uniforme escolar, desde 2013, quando a nova gestão assumiu. A entrevista foi combinada presencialmente, contudo foi realizada, via telefone, para atender a agenda da entrevistada. Entretanto o resumo da entrevista concedida foi enviado para aprovação prévia, via email. Demais informações como as imagens do kit de uniforme escolar foram enviadas, pela entrevistada, via email.

As respostas do questionário foram:

$\left.1^{a}\right)$ Vocês distribuem uniformes escolares? Sim, o kit completo. Desde 2013. São distribuídos 80 mil kits de uniformes escolares, para rede de educação infantil e ensino fundamental.

2a.) Para Prefeitura o que representa esta iniciativa no município? E Por quê? Ver nossos alunos recebendo o uniforme escolar no início do ano letivo foi realmente uma conquista alcançada, estamos trabalhando muito para melhorar ainda mais a infraestrutura educacional do nosso município.

$3^{\mathrm{a}}$.) No que consiste o kit de uniforme escolar? 01 Bermuda, 01 blusa com manga e 02 sem manga, meias, casaco de frio, calça comprida, tênis e mochila.

(4 ${ }^{\mathrm{a}}$.) Sobre o uso pelas crianças: já realizaram alguma pesquisa com as crianças sobre o uniforme escolar? Ótima aceitação por parte dos alunos da rede; pouca resistência por uma pequena parcela dos alunos dos anos finais, por se tratarem de alunos na pré - adolescência, mas contornado naturalmente pela direção da unidade. 
$5^{\text {a) }}$ Vocês compram por licitação local ou no pregão FNDE? O Prefeito optou por comprar localmente, para beneficiar as empresas do município, gerando renda e trabalho local.

6 .) E o tênis escolar? Alguns problemas foram detectados na primeira remessa de 2013, sendo prontamente solucionados. Como? Trocando o modelo do tênis.

6) O tênis novo foi enviado para ensaios laboratoriais para verificar especificações técnicas: desgaste, tração ou umidade? Não.

$7^{\text {a }}$.) O modelo novo foi desenvolvido por algum escritório de design ou centro tecnológico? Não. A empresa apresentou a partir de seu portfólio onde a decisão final coube a Secretaria de Educação.

$8^{\mathrm{a}}$.) Sobre o valor do tênis. De acordo com a numeração do tênis.

Tam: 18 a $30=32,00 / 31$ a $49=47,00$ (o par).

$9^{a}$.) Como é realizada a logística de entrega nas escolas? Em articulação com a empresa elaboramos a seguinte estratégia: toda a separação dos pedidos, embalagem e emissão de recibos de entrega eram realizadas pela empresa e a distribuição era realizada pelos caminhões da empresa e da SME com saídas direto da fábrica com destino às unidades escolares. Resposta por telefone: desta forma otimizamos o atendimento das 175 unidades escolares distribuídas nos 04 distritos do município.

$10^{\mathrm{a}}$.) Qual a frequência de pedidos por escolas para tênis?

A entrega é realizada anualmente, podendo ocorrer, se necessário, reposição pontual. Observamos que uma parcela de nossos alunos também usa o tênis escolar fora do ambiente educacional.

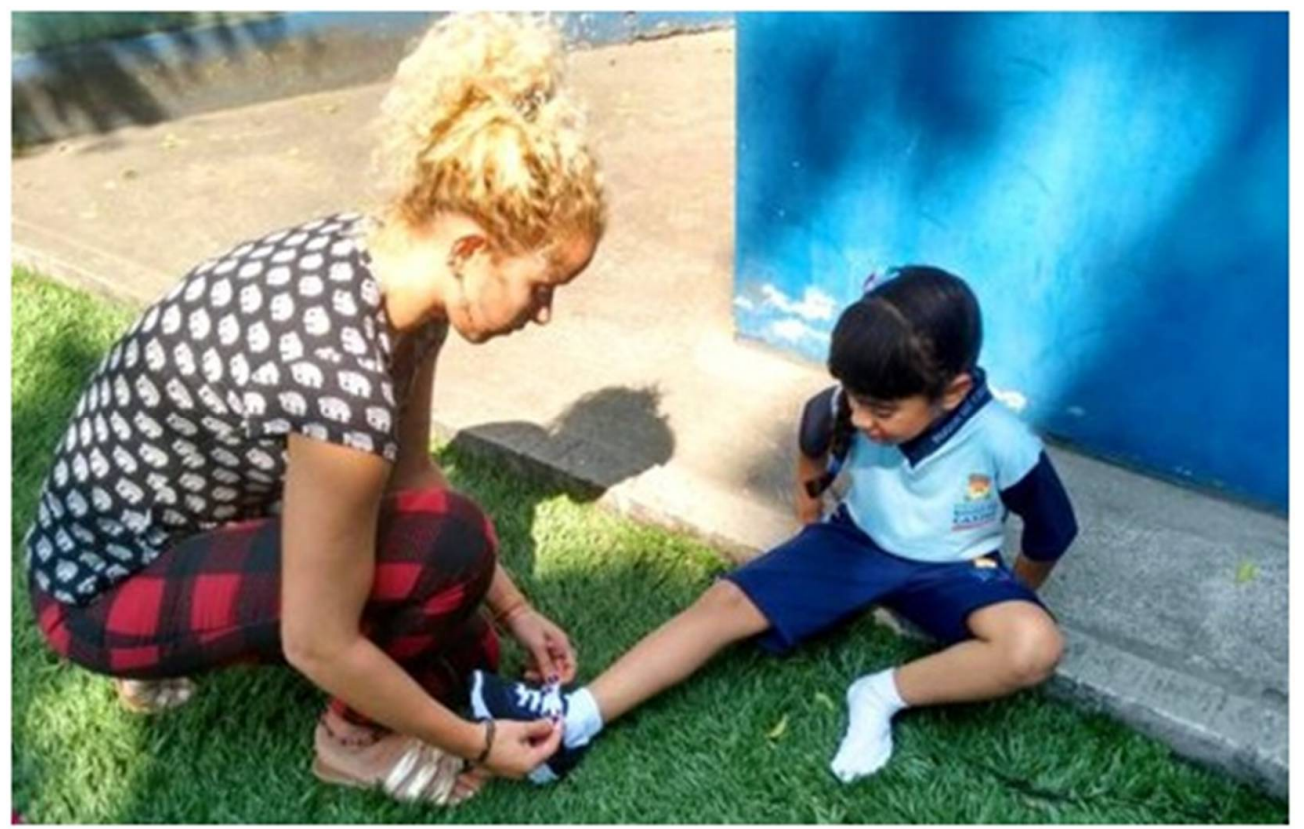

Figura 47 - Uniforme distribuído pela Prefeitura de Duque de Caxias (Fonte:

SMED de Duque de Caxias, 2015). 


\subsection{3. \\ Resultados do levantamento junto a Secretaria de Educação do Município de Belford Roxo}

A Secretaria de Educação do Município de Belford Roxo indicou a Diretora de Infraestrutura financeira, para prestar informações quanto à distribuição do uniforme escolar no município. A entrevista foi combinada presencialmente, contudo foi realizada via email, conforme solicitação da entrevistada. Infelizmente a pesquisadora não recebeu qualquer retorno do questionário enviado, conforme combinado. Desta forma não se tem informações sobre a distribuição de uniformes escolares no município de Belford Roxo, confirmada pela entrevistada no primeiro contato.

\subsection{4. \\ Resultados do levantamento junto a Secretaria de Educação da cidade de Porto Alegre}

A Secretaria Estadual da cidade de Porto Alegre ficou neutra em relação aos calçados escolares, e indicou buscar informações junto ao FNDE. Demais Secretarias da Cidade do Rio de Janeiro e São Paulo também não se dispuseram a conversar sobre o assunto. Contudo, sempre que possível a pesquisadora entra em contato para tentar uma nova oportunidade sobre as informações desejadas.

\subsection{5.}

Resultados do levantamento junto a Secretaria de Educação de Palmares do Sul

Em 2011, foi feito contato com a Prefeitura de Palmares do Sul, no Estado do Rio Grande do Sul, cidade onde o projeto "Fábrica da Inclusão" estava sendo implementado pelo grupo de pesquisa em design e ergonomia do PPGEP/ UFRGS, para descobrir que parâmetros definiam a distribuição do uniforme escolar. A resposta obtida da Secretaria Municipal de Educação da Cidade foi:

Depende do projeto e plano de governo da atual gestão. O uniforme escolar é uma necessidade e o tênis é o item mais difícil. Quando achamos fornecedor, o produto não é de qualidade. Quando compramos o produto, o que é entregue não atende as especificações do protótipo anteriormente apresentado. Parece que por saberem que o calçado e o uniforme serão distribuídos gratuitamente, acham que devem ser de baixa qualidade. Aqui na Prefeitura desistimos de comprar.

De fato, não obtivemos uma resposta clara e objetiva a respeito. Esperávamos encontrar a indicação de uma Portaria, Lei ou rubrica orçamentária. 
Fomos incentivados, pela Secretaria Municipal de Educação da Cidade de Palmares do Sul, a procurar o Fundo Nacional de Desenvolvimento da Educação (FNDE), como sendo o responsável pela compra nacional do uniforme escolar.

A Secretaria Municipal de Palmares do Sul demonstrou que estariam satisfeitos se conseguissem manter a compra de produtos/componentes de qualidade e iniciar o projeto de distribuição do uniforme escolar completo, conforme Programa já aprovado pela Prefeitura da cidade. E que não levavam adiante por falta de fornecedores qualificados e bem intencionados.

Em resumo, diante das informações coletadas junto as Secretarias de Educação, fica claro que não há parâmetros claros para a distribuição do uniforme escolar. Contudo foi possível perceber que há entraves relacionados à qualidade de fabricação quando se tem interesse em comprar e distribuir os uniformes escolares. Como referencia, a instituição governamental indicada foi o FNDE.

\subsection{6.}

Resultados do levantamento junto ao Ministério da Educação (MEC) e o Fundo Nacional de Desenvolvimento da Educação (FNDE)

O Fundo Nacional de Desenvolvimento da Educação (FNDE), autarquia federal responsável pela execução de políticas educacionais do Ministério da Educação (MEC), foi contatado para descrever o panorama nacional sobre a situação de distribuição do uniforme escolar. Aceitou participar, presencialmente e via e-mail, conforme necessidade da pesquisadora.

A primeira informação concedia foi sobre como o Governo Federal entende o uso do uniforme escolar. E os itens citados foram:

- Preserva o vínculo com a escola: fortalecendo o laço entre os alunos e a escola, pela identificação desse aluno, como parte integrante de um grupo social;

- Auxilia no orçamento familiar: evitando que as famílias, principalmente as cadastradas pelo Programa Bolsa família, utilizem tal renda para compra do uniforme;

- Minimiza a discriminação social, reduzindo a vergonha, questões de baixa autoestima e isolamento;

- Cria hábitos de higiene, organização e manutenção de ordem com o próprio uniforme e material didático;

- Assegura os alunos, bem como o ambiente escolar. 
Contudo, o próprio Governo Federal categoriza a distribuição do uniforme escolar como assistencialismo e não como medida de assistência social, principalmente o calçado. Mesmo assim, o FNDE realiza um Pregão Nacional para registro de preços dos itens do kit básico nacional de uniforme escolar, tendo como um dos componentes o calçado escolar. Cabe uma pergunta: por quê? Até hoje, setembro de 2015, sem resposta.

Não existe lei nacional sobre o assunto, entretanto nenhum direito pode sobrepor o direito de acesso à educação e à obrigatoriedade escolar, pois são considerados mais importantes do que qualquer deliberação da escola ou lei estadual ou municipal (Constituição Federal, art. 205, incisos I e art. 208, §1 ${ }^{\circ}$ ). Se o uso obrigatório da vestimenta esteja definido pela escola, ou por deliberação de um conselho escolar, o Poder Público deverá fornecer as peças, gratuitamente, a todos os estudantes. Caso contrário, a distribuição ou não, fica vinculada as orientações de planejamento estratégico dos gestores municipais e estaduais.

$\mathrm{O}$ argumento que fortalece a obrigatoriedade do uso do uniforme escolar tem origem no discurso dos pais e profissionais das escolas entrevistadas sobre segurança do aluno. Identificar uma criança como sendo aluno de uma escola, ou que ela esteja no trajeto de casa-escola-casa, é fundamental nas regiões de comunidades consideradas violentas em relação ao movimento do tráfico de drogas, ou até mesmo, pela grande distância percorrida pelo aluno neste trajeto. Este argumento é recorrente no grupo de itens citados pelos pais e profissionais das escolas.

Para um melhor atendimento aos estados e municípios, o FNDE configurou um kit básico de uniforme escolar, composto por 20 itens como: Calça Feminina/ Masculina Jeans; Calça Feminina/ Masculina Brim (tipo de tecido); Bermuda Feminina/ Masculina Jeans; Bermuda Feminina/ Masculina Brim; Saia Jeans; Saia Brim; Camiseta Meia-malha; Camiseta Regata Feminina/ Masculina para Educação Física; Calção de Ginástica; Bermuda Feminina/ Masculina para Educação Física; Agasalho com Capuz; Agasalho sem Capuz; Meia; Boné e Tênis. Segundo a FGV (2010), a demanda esperada de cada bem no registro de preços, em 2010, foi no total de 2.228.666, contudo alguns entraves foram identificados pelo estudo da FGV como: 
Em relação ao tênis, neste numero não estão incluídos. Há a informação de que integrantes da indústria de calçados também participaram da especificação. Certas empresas podem ter de realizar adequações.

Segundo o FNDE, o processo de compra pública foi implementado para assegurar transparência no processo licitatório e de economia aos cofres públicos de estados, municípios e do governo federal. Ele é organizado com base nas estimativas das necessidades regionais do Brasil. A partir destas informações, o FNDE realiza licitações e registra os preços que passam a ter validade em todo território nacional. A adesão no processo de compra via pregão nacional, permite aos estados e municípios a composição do kit de acordo com suas necessidades.

A partir deste procedimento, diz o FNDE, há ganhos de escala, favorecendo não só o governo federal, mas estados e municípios, que podem aderir a esses registros de preços, realizando, assim, suas compras de forma mais rápida e racional, como também impulsionando o desenvolvimento econômico. Com a adesão ao pregão do FNDE, tornam-se desnecessárias as licitações regionais, bastando aos entes federados pedir adesão ao registro de preços, já disponibilizado pelo FNDE, para efetivar a compra.

A quantidade de uniformes pode ser calculada com base na demanda de alunos em idade para uso de uniforme, o que exclui os alunos da educação básica matriculados em creches e pré-escola, do ensino Médio (incluindo o médio integrado e normal magistério), os alunos da Educação de Jovens e Adultos (EJA presencial Fundamental), Médio (incluindo a EJA integrada à educação profissional), bem como as matrículas dos alunos da Educação Especial. O número de alunos matriculados nas escolas de ensino público regular e especial do Brasil, em 2012, foi 37.830.103 (sendo 5.190.791 na Educação Infantil, 25.451.815 no Ensino fundamental, e 7.185.497 no Ensino médio). Em 2014 foram de 28.459.667 alunos matriculados no ensino fundamental das redes estaduais e municipais, urbanas e rurais em tempo parcial. Já no primeiro semestre de 2015 foram de 21.431.522 matrículas nas redes de ensino público de todo o Brasil (demanda nacional).

O FNDE organiza o pregão nacional para compra do calçado escolar objetivando economia aos cofres públicos, na transparência de processos administrativos e otimização na fabricação e logística de entrega. Mas ganha o edital a empresa que apresentar melhor preço, apesar da existência da Lei que 
instrui sobre compras públicas sustentáveis (Art. 3o da Lei No 8.666/1993, redação dada pela Lei no 12.349, de 2010) (Biderman et al., 2008). Entretanto a aquisição é de grande quantidade de peças, e o FNDE espera, sempre, conseguir preços mais baixos, em benefício de estados e municípios que aderirem ao registro para a compra de uniformes com seus próprios recursos. A decisão da empresa vencedora, entre outros pré-requisitos, é o menor preço, mas também a qualidade do produto.

A qualidade dos produtos é uma exigência do próprio protocolo do processo licitatório, sendo o processo de produção e as especificações técnicas, e cada item do kit, acompanhado por laboratórios atestados pelo Instituto Nacional de Metrologia, Normalização e Qualidade Industrial (INMETRO).

São contratados profissionais para a configuração da especificação técnica de cada componente do kit de uniforme escolar. Por exemplo, o calçado, proposto no Edital 2010/2011, foi especificado pelo Centro Tecnológico do Calçado SENAI e pela pesquisadora deste trabalho. Ao profissional participante, não basta apresentar as especificações, pois é necessária a construção de um protótipo para ensaios laboratoriais, seguindo as normas da Associação Brasileira de Normas Técnicas (ABNT) quanto à segurança, durabilidade, toxicidade, conforto (aspectos objetivos como umidade, dureza, transpiração, temperatura, migração de corantes dos componentes e medidas da forma) (FNDE, 2012) (CB-11, 2015).

A qualidade ambiental também tem que ser assegurada, conforme a Lei $\mathrm{N}^{\circ}$ 8.666 (1993) que instrui sobre compras públicas sustentáveis e a Agenda Ambiental da Administração pública (A3P) porque é exigida a descrição de todo o ciclo de vida do produto nos processos licitatórios.

Apesar da alta demanda por uniforme, relacionada ao número de alunos matriculados nas escolas de ensino público fundamental do Brasil, os pedidos são realizados sazonalmente, de acordo com os interesses dos municípios e estados, o que dificulta a participação das empresas nos editais para registro de preços. Não há como uma empresa se comprometer com tamanho e número de peças, no planejamento de sua produção, sem conhecer a real demanda, o prazo e a região que deverá fornecer.

Segundo o FNDE, as demandas, apesar de sazonais, podem conter qualquer quantidade de pares de calçados. Esta condição de imprevisibilidade, segundo a Associação Brasileira das Indústrias de Calçados (ABICALÇADOS) inviabiliza a 
participação das empresas brasileiras fabricantes de calçados. Nas palavras de um empresário entrevistado: seria como dar um tiro no próprio pé.

$\mathrm{Na}$ tentativa de minimizar os desafios para o fornecimento de uniformes em função dos pedidos sazonais de calçados e da capacidade produtiva das empresas brasileiras fabricantes, a Fundação Getúlio Vargas (2010), a pedido do FNDE, realizou um estudo com o objetivo de analisar e propor estratégias para aquisição dos uniformes escolares, por meio de leilão eletrônico com registro de preços. Especificamente o estudo foca em fornecer informações para maximizar a utilização dos recursos públicos, excluir quaisquer incertezas comerciais e auxiliar as empresas interessadas em participar do registro de preços no atendimento aos padrões técnicos determinados no edital. O estudo foi construído por cinco análises, quais sejam: Análise da Definição do Produto Licitado, Análise do Mercado, Análise Teórica do Processo de Compra, Análise das Formas de Compra e Análise de Formas de Pagamento.

A Análise do Mercado levantou a estrutura e as características gerais e relevantes do mercado nacional e mundial de confecção e calçados; as características técnicas, industriais e econômicas dos atores relevantes; a cadeia produtiva e estrutura de custos destes atores; cotações dos produtos a serem licitados, por meio de pesquisa de preços. A Análise Teórica do Processo de Compra enfatizou a teoria de leilões de múltiplos objetos com sinergia, sob incertezas, riscos de conluio $^{33}$ e cartelização. Já a Análise das Formas de Compra contemplou as diversas alternativas de modelagem de leilões quanto as suas vantagens e desvantagens, tendo em vista os resultados das demais análises e o resultado da Análise de Formas de Pagamento, especificamente, quanto aos seus impactos sobre os possíveis resultados do leilão.

A Análise de formas de compra apresentou parâmetros práticos que devem embasar a formatação do leilão em duas dimensões possíveis de fracionamento do pregão, quais sejam: o fracionamento do portfólio de produtos e o fracionamento geográfico (por localidade). Devido à heterogeneidade entre regiões geográficas e categorias de produtos, tal fracionamento permite aproveitar vantagens competitivas, não havendo elevados ganhos de escopo a perder; a demanda

33 Conluio - Combinação entre duas ou mais pessoas para lesar outrem; maquinação, trama, conspiração (Ferreira, 2014). 
projetada tem proporções vultosas em relação à escala característica das indústrias produtoras. Se não houver um fracionamento significativo dos lotes, ocorre uma virtual imposição do conluio, beneficiando inclusive os players mais inclinados a recorrer à importação para suprir a demanda.

Considerou-se que 6 critérios deveriam ser seguidos tanto quanto possível: (i) os lotes devem ter dimensões compatíveis entre si; (ii) a demanda total de cada lote deve permitir a participação de atores locais; (iii) a demanda total de cada lote deve ser grande o suficiente para representar um atrativo à participação dos grandes atores; (iv) em casos nos quais haja o risco de não existir produção local de dimensões suficientes para atender à demanda, deve ser considerada a possibilidade de incluir a localidade em outro lote; (v) dado o risco de contestação, foram excluídas soluções que envolvessem a inclusão de regiões geográficas desconectadas entre si em um mesmo lote; (vi) dado que as redes estaduais também participarão do registro de preços, não há fragmentação intraestadual, ou seja, cada estado faz parte de apenas um lote.

Para elaborar a proposta de fracionamento geográfico apresentada na figura 48, foi levado em consideração os critérios, anteriormente listados, bem como o número, localização e capacidade produtiva das empresas e suas unidades fabris, portanto uma proposta que conjugou as considerações de mercado de forma a permitir que um grau elevado de atores tenha condições e incentivos para competir por cada lote. Mas cabe ressaltar que: o critério de julgamento será "Menor Preço por Item" (FNDE, 2012).

\begin{tabular}{|l|r|}
\hline Proposta de Fracionamento Geográfico \\
\hline Fracionamento por UF's & $\begin{array}{l}\text { Em número total de } \\
\text { conjunto-aluno. }\end{array}$ \\
\hline 1 - AC, AM, RR, PA, AP & 276.278 \\
\hline 2 - RO, MT, TO, MA, PI & 293.295 \\
\hline 3 - CE, RN, PB. & 269.852 \\
\hline 4 - PE, AL, SE. & 247.518 \\
\hline 5 - BA & 261.848 \\
\hline 6 - MG, ES, RJ & 286.852 \\
\hline 7 - SP & 307.551 \\
\hline 8 - GO, DF, MS, PR, SC, RS & 285.473 \\
\hline
\end{tabular}

Figura 48- Número de lotes distribuídos por regiões do País

O FNDE demonstrou interesse na localização de empresas que queiram fabricar o calçado escolar, por isso investiram na estratificação do território 
brasileiro, para melhor otimizar o preço, a logística de entrega e a adesão de empresas ao pregão.

Demonstraram interesse em resolver a questão do período de solicitação e adesão por parte dos municípios e estados, bem como a definição de quantidades de itens por produto, o que impacta diretamente no planejamento do processo de fabricação, consequentemente na decisão das empresas participarem ou não do processo de registro de preços - Pregão Nacional.

Ainda não conseguem determinar quais municípios irão aderir ao pregão, visto que não é uma obrigatoriedade a distribuição do kit de uniforme, tão pouco qualquer item, como o calçado, a época de solicitação e a quantidade de produto, o que prejudica a adesão de empresas para fornecimento do produto.

Quanto ao Governo categorizar a distribuição do calçado escolar como assistencialismo, a única opção de argumentação encontrada foi de que não há uma classificação ou uma relação direta, do uniforme escolar e de seus itens, em um dos programas de assistência social do Governo, amparados pelo Art. 208, inciso VII, da Constituição Federal do Brasil (2008), que efetivam o dever do Estado com a educação mediante: o atendimento ao educando, no ensino fundamental, através de programas suplementares de material didático-escolar, transporte, alimentação e assistência à saúde. Não é compreendido que o calçado escolar possui a função de proteção e prevenção à saúde, portanto é assistência. Desta forma, o kit perde sua prioridade nas definições de rubrica orçamentária da verba pública, destinada aos produtos de assistência escolar, em todo território nacional.

O contato com o FNDE possibilitou compreender o papel do governo federal no fornecimento do calçado escolar, entendido como uma medida assistencialista; a existência de um kit básico de uniforme escolar nacional, tendo como um dos componentes de maior dificuldade no fornecimento, o calçado escolar; a obrigatoriedade da distribuição do calçado quando há exigência do uso do uniforme escolar por alguma escola ou grupo de pais de alunos e sobre a gerência da prefeitura na definição de compra (ou não) do uniforme e calçado escolar, o que não, necessariamente, precisam ser adquiridos no mesmo processo de compra ou solicitação para escolas. 


\subsection{7. Definição dos requisitos obrigatórios para o projeto do calçado escolar}

O planejamento para o desenvolvimento do produto deverá ser guiado por requisitos que o projeto deve satisfazer, ou seja, as restrições, as especificações, considerações e as variáveis, elencadas por duas categorias: os obrigatórios, aqueles que devem ser cumpridos para que a solução seja aceita, e os desejados, aqueles que no possível devem ser cumpridos (Pugh, 1990; Brod, 2009). Um dos requisitos obrigatórios para o projeto do calçado escolar, até o ultimo edital em 2015, é que o produto deve atender uma lista de especificações técnicas, com base em normas da ABNT, prescritas por um Laboratório de Ensaios técnicos para calçados, credenciado pelo INMETRO.

Contudo, está em projeto e discussão, pelo CB-11 - Comitê Brasileiro de Couro, Calçados e Artefatos de Courro (CB-11, 2015), órgão da estrutura da ABNT - Associação Brasileira de Normas Técnicas, responsável pela coordenação e planejamento das atividades de normalização relacionadas com seu âmbito de atuação, neste caso o setor coureiro-calçadista do Brasil, a Norma específica para calçados escolares: Norma de Conforto em calçados escolares Requisitos e ensaios. O projeto tem previsão de estar disponível para consulta nacional no mês de outubro de 2015, conforme o CB-11 informou à pesquisadora. A consulta pública é um procedimento exigido pela ABNT para que o projeto de uma norma passe a vigorar como Norma Técnica Brasileira.

A demanda para esta norma surgiu dos resultados da última audiência pública, convocada pelo FNDE aos agentes sociais interessados na demanda de compra de tênis escolares para as escolas públicas do Brasil, quando a ABICALÇADOS apresentou contribuições pontuais às especificações técnicas contidas no edital, em discussão nesta audiência. A intenção desta entidade seria de ampliar as oportunidades das especificações do Edital para que uma quantidade maior de Empresas brasileiras, fabricantes de calçados escolares, participasse junto ao Pregão do FNDE. Participação que não estava ocorrendo, porque as empresas alegavam que as especificações do Edital restringiam a competitividade, em relação ao tipo de processo de fabricação exigido para o tênis: tipo vulcanizado. Contudo, o FNDE estava apresentando um modelo desejado pelas 
crianças, tomando como referencia a pesquisa realizada por esta pesquisadora, conforme descrita no item 4.2.2 e Apêndice III.

A proposta do sistema e do método em design é que os grupos sociais produtivos locais possam atender os requisitos obrigatórios de atenção às especificidades do produto quanto à segurança do usuário; custo; e de sustentabilidade, segundo as diretrizes contidas no Decreto 7.746/10 (Arantes, 2014):

I - menor impacto sobre recursos naturais como flora, fauna, ar, solo e água; II - preferência para materiais, tecnologias e matérias-primas de origem local; III - maior eficiência na utilização de recursos naturais como água e energia; IV - maior geração de empregos, preferencialmente com mão de obra local; V - maior vida útil e menor custo de manutenção do bem e da obra; VI - uso de inovações que reduzam a pressão sobre recursos naturais; e VII - origem ambientalmente regular dos recursos naturais utilizados nos bens, serviços e obras.

Arantes (2014) cita que a verificação dos critérios segue os mesmos procedimentos da verificação dos requisitos de desempenho e qualidade, ou seja, das especificações técnicas, normalmente consideradas pelo FNDE, com base nas normas da ABNT, na fase de aceitação no Pregão, como trata da utilização do poder de compra do setor público para gerar benefícios econômicos e socioambientais, há cuidados na comprovação dos requisitos que são levados em consideração, como por exemplo, não frustrar a competitividade entre os licitantes, mesmo que os requisitos obrigatórios sejam para selecionar a alternativa mais vantajosa para a compra do calçado escolar. Por isso, tais requisitos não podem concorrer entre si, como as especificações contidas na Norma de Conforto do Calçado escolar e os critérios de sustentabilidade.

Segundo Arantes (2014), sempre haverá algum nível de restrição à competição, mas não poderá ser admitida a competição sem uma justificativa técnica que comprove a equidade nos critérios exigidos. Segundo o FNDE, em consulta pela pesquisadora, uma alternativa, caso seja identificada incompatibilidade das especificações técnicas com as exigências dos instrumentos da administração pública de maior valor à sociedade, os requisitos que seriam compulsórios deixam de ser na formatação do Edital.

Diante o contexto, o método utilizado para análise dos requisitos obrigatórios para fabricação do calçado escolar foi:

1) identificar as especificações técnicas para fabricação do calçado escolar; 
2) contatar o CB-11 para acesso ao documento do projeto à Norma para Conforto em calçados escolares - requisitos e ensaios;

3) solicitar acesso ao documento para o Coordenador do CB-11, via email, conforme protocolo do CB-11, que disponibilizou o documento em 19.09.2015;

4) fazer uma correlação comentada entre os itens do projeto da norma específica de conforto ao calçado escolar do Brasil (CB-11, 2015) com as sete estratégias de sustentabilidade (Brezet e Van Hemel, 1997), e demais atributos que estruturam as referências ao método em design (Capitulo 3, item 3.6) do sistema-modelo.

O Contato com o CB-11 foi realizado pessoalmente, e a solicitação conforme exigência do protocolo do Comitê foi realizada por email, como também o recebimento do arquivo do Projeto à Norma.

A Comparação comentada entre os itens do projeto da norma específica de conforto ao calçado escolar do Brasil (CB-11, 2015) com as sete estratégias de sustentabilidade (Brezet e Van Hemel, 1997) visam fornecer consistência e clareza aos requisitos obrigatórios do método em design à projetação do calçado, tanto para uma demanda nacional, como para a demanda territorial, porque de uma forma geral o conceito do calçado segue o ciclo de vida, proposto pelas características do sistema e do método em design: o calçado será fabricado, prevendo que seu ciclo de vida seja ampliado com a manutenção, e que após o uso, o mesmo seja desmontado para separação e reaproveitamento de cada parte, destinadas aos processos de reciclagem industrial e reincorporados como matériaprima em novos ciclos produtivos. O manejo do resíduo orgânico para o processo biológico de reciclagem terá como destino as composteiras locais.

\subsection{8.}

Comparação do projeto da norma específica de conforto do calçado escolar com as estratégias de sustentabilidade

O projeto é composto por 15 normas, sendo que a norma ABNT NBR 14834 que define o Conforto do calçado e de seus componentes - Requisitos e ensaios são determinados por um conjunto de normas sendo elas: ABNT NBR 10455:2014, ABNT NBR 14835:2013, ABNT NBR 14836:2014, ABNT NBR 14837:2011, ABNT NBR 14838:2011, ABNT NBR 14839:2013, ABNT NBR 14840:2011 e ABNT NBR 16037:2012. 
As demais normas que formam a lista de 15 normas são: ABNT NBR 14742 - Construção inferior do calçado - Solas, solados e materiais afins: determinação da resistência a flexões contínuas em um ângulo de 90; ABNT NBR 15171 Calçados: Determinação da resistência à flexão; ABNT NBR 15172 - Calçados: terminologia; ABNT NBR 14738 - Construção inferior do calçado - solas, solados e materiais afins: determinação da resistência ao desgaste por abrasão especial; perda de espessura; ABNT NBR 15379 - Calçados: determinação da resistência da colagem na banda lateral e ABNT NBR 14826 - Componentes plásticos para calçados e artefatos: identificação do material-base.

O método de análise seguiu 3 critérios para definir se atendem os propósitos do método em design do sistema-modelo: (1) aquelas que atendem; (2) aquelas que não atendem; (3) e as que atendem com considerações. Esta análise foi realizada em uma planilha, considerando uma nota de 0 a 7 para cada norma em relação a cada estratégia da sustentabilidade, sendo 0 (não se relaciona) ou 7 (atende). Para cada norma ou grupo de normas foi gerado um gráfico radar para melhor orientar, visualmente, os comentários realizados da pesquisadora.

Foram identificadas 5 normas que atendem os propósitos do método em design sendo:

$1^{\mathrm{a}}$.) a Norma ABNT NBR 14834, para medir Conforto do calçado e componentes - Requisitos e ensaios Atende as propostas do método em design porque prioriza o conforto ao usuário, e apesar de ser uma percepção subjetiva utiliza os parâmetros da norma ABNT NBR 14840 que mede o índice de percepção do usuário. O que deverá ser realizado após o protótipo confeccionado.

$2^{\mathrm{a}}$ e $3^{\mathrm{a}}$ ) As normas ABNT NBR 14836 - Calçados - Determinação dinâmica da distribuição da pressão plantar e ABNT NBR 14839 - Calçados Determinação do índice de pronação do calçado porque estão relacionadas à segurança e o conforto biomecânico no uso do calçado. Parâmetros relativos à ergonomia do calçado que devem ser aliados aos dados antropométricos dos alunos, que podem ser coletados no período de matrícula ao novo ano letivo. Uma proposta que auxilia o planejamento estratégico do sistema de produção, especificamente utilizados para construção da forma do calçado que dará suporte à modelagem do cabedal e do solado do calçado.

$4^{\mathrm{a}}$ ) As normas ABNT NBR 14742 - Construção inferior do calçado Solas, solados e materiais afins - Determinação da resistência a flexões 
contínuas em um ângulo de $90^{\circ}$ atende, desde que alcance a mesma resistência de conforto assegurando todas as estratégias do ecodesign, principalmente no que tange a minimização dos componentes e insumos para a estrutura de construção de solado.

5 ) A norma ABNT NBR 14840 - Calçados - Determinação dos níveis de percepção do calce, atende, mas cabe utilizar uma ferramenta de análise qualitativa e quantitativa que apoie na coleta e na análise da percepção do usuário quanto ao protótipo confeccionado pelo grupo social produtivo do território. $\mathrm{O}$ método de design do sistema indica o método de design macroergonômico (Fogliatto e Guimarães, 1999).

Dentre as normas que não atendem aos propósitos do método em design foi identificada uma: ABNT NBR 15379 - Calçados — Determinação da resistência da colagem na banda lateral, porque no processo de desmontagem para reciclagem das partes os materiais colados sofrerão delaminação, ao desmontar, partes ficarão presas uma a outra, ficando resíduos nas duas superfícies. Nos processos de reciclagem torna-se um problema. Se os materiais são compatíveis e a cola também, podem ser reutilizados, quando não, seu destino são os aterros sanitários, não atendendo aos propósitos do sistema.

Foram identificadas 8 normas que atendem o sistema, mas que precisam adequação às sete características do ecodesign, sendo elas:

$1^{\text {a) }}$ ABNT NBR 10455:2014 - Climatização de materiais usados na fabricação de calçados e correlatos. Esta climatização tem a finalidade de dar um padrão de temperatura $\left(23^{\circ}+/-2\right.$ : de $21^{\circ}$ a $\left.25^{\circ}\right)$ e umidade (De 40 a 50) do calçado e seus componentes para iniciar os ensaios laboratoriais.

2 ${ }^{\text {a }}$ ABNT NBR 14835 - Calçados — Determinação da massa do calçado: o peso do calçado tem relevância, porque será usado pelo aluno, mais que o tempo de permanência na escola, porque de acordo com os relatos (item 4.2.2 deste capítulo) algumas crianças só possuem este calçado para usar. Uma solução seria atuar com inovação tecnológica às propriedades dos componentes (atóxicos) para reduzir a massa específica ou na redução de peças para formação de um calçado $(\mathrm{D} f \mathrm{E}$ design for envinronment $=\mathrm{D} f \mathrm{~A}$ design for assembly $+\mathrm{D} f \mathrm{D}$ design for disassembly). 
3) As normas ABNT NBR 14837, ABNT NBR 14838, ABNT NBR 14737, ABNT NBR 16037:2015, ABNT NBR 15171, ABNT NBR 14738 possuem a mesma distribuição no gráfico radar sendo os comentários:

- ABNT NBR 14837 - Calçados - Determinação da temperatura interna do calçado: alguns territórios possuem temperaturas diferentes em relação ao clima. A escolha dos componentes precisa respeitar o ambiente local;

- ABNT NBR 14838 - Calçados - Determinação do índice de amortecimento do calçado: relevante para o impacto durante as atividades escolares, desde que as propriedades dos insumos para solado sejam compatíveis com um ciclo de vida sem impacto ambiental;

- ABNT NBR 14737 - Construção inferior do calçado - Solas, solados e materiais afins - Determinação da densidade em corpos de prova - Método hidrostático; ABNT NBR 14738 - Construção inferior do calçado - Solas, solados e materiais afins - Determinação da resistência ao desgaste por abrasão especial e ABNT NBR 15171 - Calçados - Determinação da resistência à flexão: podem ser aceitas desde que minimizem os materiais, determinando o solado com mesmo material ou compatíveis entre si para atender um ciclo de vida sem impactos ambientais e atóxicos aos seres humanos.

- ABNT NBR 16037:2015 Determinação de conforto em componentes para calçados - Forros: o forro não seria necessário, caso fosse utilizado um material de cabedal que permita contato com a pele (atóxico e de tatilidade permissiva à pele) e resistente ao rasgamento;

O projeto da Norma além de definir parâmetros para as análises biomecânicas, de toxicidade, de resistência física e mecânica de cada componente na estrutura do calçado, apresenta normas com propostas ao modelo e partes que compõem o objeto. Assim, da mesma forma que as normas foram analisadas quanto às estratégias do ecodesign, estas também o serão.

Foram realizadas análises quanto à proposta de cada parte listada abaixo:

1) forma do calçado (ABNT NBR 16260 e 15159);

2) modelo de tênis (ABNT NBR 15172);

3) cabedal;

4) contraforte;

5) couraça interna ;

6) forro de cabedal; 
7) debrum de acabamento/talão;

8) costuras;

9) palmilhas de montagem;

10) fixação do calçado ao pé;

11) sobrepalmilhas;

12) Ilhoses;

13) biqueira,

14) sobre a biqueira

15) banda lateral

16) sola.

A figura 49 é um modelo similar ao tênis proposto pela norma, mostrando a função de cada parte componente. Quanto às estratégias do ecodesign, percebe-se que nesta lista de 16 partes, há oportunidade de melhorias com a minimização da quantidade de componentes.

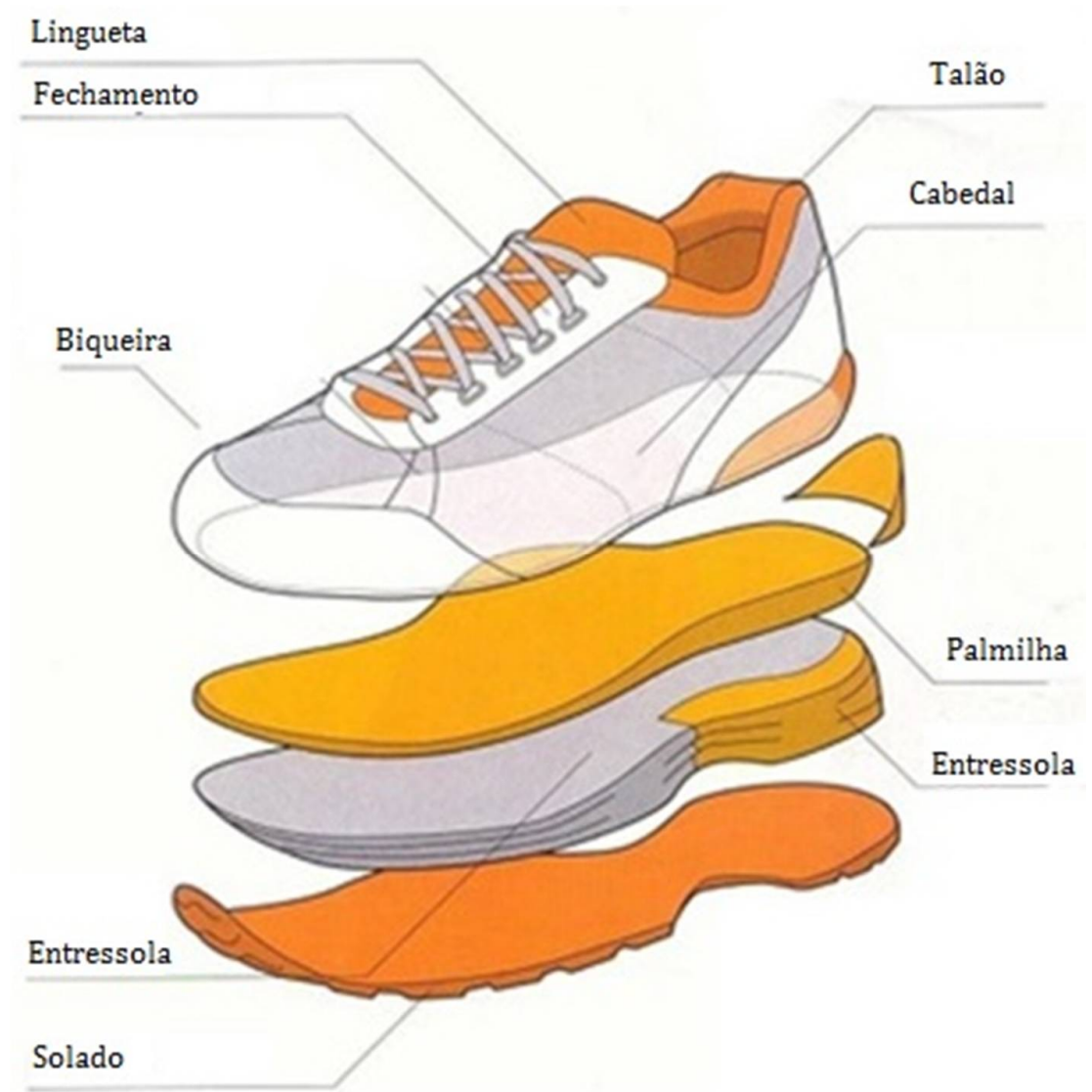

Figura 49 - Estrutura, em número de partes, de modelo similar ao proposto pelo projeto da norma específica ao calçado escolar do Brasil (A partir de Tênis para corrida, 2015). 
Contudo, para definir as partes que compõem o tênis ou modelo a ser fabricado, em cada território, serão levadas em consideração as análises realizadas sobre cada peça do modelo proposto pelo projeto da Norma. As análises podem ser consultadas nos Apêndices IV, V, VI, VII e VIII.

A primeira análise relaciona-se à forma do calçado, componente imprescindível para iniciar a projetação do calçado escolar, porque é a reprodução do pé humano. No projeto de produto, pode-se pensar alternativas de montagem do modelo na manufatura sem o uso da forma, considerando que o pé humano será o conformador do modelo, ao invés do modelo de calçado já sair da fábrica conformado por processos físicos e mecânicos, alternativa possível à manufatura do calçado escolar porque é um modelo que não possui salto alto, assemelhandose a modelos de tênis. Assim o custo desta manufatura reduz, e não seria um problema caso os alunos optem por um estilo de moda.

O modelo do tênis proposto no projeto da norma possui grande número de componentes exigindo: controle do ciclo de vida de materiais diversos, mais processos manuais para união das partes e na reciclagem para desmontagem, o que não garante aproveitamento de todos os componentes se estiverem colados. Os tipos de montagem e construção do modelo dificultam a reciclagem, se por injeção direta do solado, colado ou vulcanizado (solado no cabedal). O tipo proposto é montado com costura unindo o cabedal e o solado, o que permite fácil montagem e desmontagem e, portanto, contribui para a manutenção, reuso e reciclagem. Os sapateiros locais são, portanto, não só responsáveis pela montagem e manutenção do produto, mas também um elo fundamental na cadeia da logística reversa, enviando para as fábricas as partes que podem ser reutilizadas no metabolismo técnico.

O cabedal é imprescindível, contudo o grande número de componentes exige maior custo humano no processo montagem e desmontagem, além de não garantir, caso as partes estejam coladas e os componentes não forem compatíveis entre si para reciclagem. Quando montado com peças menos recortadas, maior será o custo do material pelo aproveitamento de corte. Uma opção será o fornecimento de matéria-prima no território, contudo não sendo possível usar qualquer resíduo como material para o cabedal, para redução deste custo. $\mathrm{O}$ resíduo deve ser analisado quanto à toxicidade e reciclagem. 
A couraça e o contra forte podem ser excluídas como componentes do calçado, cuja função é dar estrutura ao calçado e proteção ao pé, podendo ser substituídos por um solado com desenho permitindo laterais mais altas no bico e no traseiro, mais envolvente ao pé, até as possibilidades técnicas que a matrizaria irá permitir.

O forro permite conforto na escolha dos materiais que estarão em contato com a pele do pé, mas o forro poderá ser excluído. Se tiver que escolher entre o uso do forro ou o debrum (viés nas bordas), é melhor o forro, que poderá ter duas funções, proteção ao pé, resistência ao cabedal e prolongamento da vida útil, ajudando a impedir rasgamentos. Exclui o debrum porque o forro poderá ser unido por costura luva pela borda do cabedal e depois virado para a área interna do tênis.

Quanto ao solado, o projeto da norma específica para calçados escolares, define que esta peça é parte integrante da base inferior do calçado, podendo ser fabricada em polímero atendendo aos índices mínimos de abrasão e escorregamento. Não foram identificadas observações no Projeto da Norma sobre a exigência do uso de polímero que tenham propriedade para reciclagem ou reuso. Contudo foi identificado o quadro sobre substâncias atóxicas que não deverão ser usados na fabricação.

A sola também deverá passar por ensaios mecânicos como: 1) Determinação da resistência a flexões contínuas (até 30.000 flexões). Contudo a norma não apresenta uma estimativa do tempo de vida deste solado pelo número de flexões que exige, informação necessária para auxiliar na escolha do material para fabricação do solado e controle do ciclo de vida.

Após o estudo das normas, foi investigada, junto a um laboratório de ensaios técnicos para calçados, localizado na cidade Novo Hamburgo, a referência para determinar os parâmetros de medição das normas. A resposta da técnica foi:

Não temos nenhum protocolo como referência... mas no último curso que participei sobre atualização das normas, a discussão do grupo girou em torno das exigências do prazo de garantia do Código de Defesa do Consumidor para produto durável. Então este é o parâmetro, durar no mínimo o tempo previsto no código (a entrevistada preferiu não se identificar). 
Como o calçado escolar é um produto durável, o art. 26, do Código de Defesa do Consumidor (CDC - Lei $n^{\circ} 8.078$ de 11 de Setembro de 1990) que trata do tempo de garantia cita:

O direito de reclamar pelos vícios aparentes ou de fácil constatação caduca em:

I - trinta dias, tratando-se de fornecimento de serviço e de produtos não duráveis;

II - noventa dias, tratando-se de fornecimento de serviço e de produtos duráveis.

$\S 1^{\circ}$ Inicia-se a contagem do prazo decadencial a partir da entrega efetiva do produto ou do término da execução dos serviços.

Esta informação foi conferida junto aos usuários de calçados escolares, distribuídos pelo Município de Duque de Caxias no Rio de Janeiro, um dos territórios estudados. A pesquisadora trocou calçados novos pelos usados com uma mãe, residente do município (figuras 50 e 51), que possui 3 filhos matriculados em escolas municipais. A mãe dos alunos entrevistada informou que: o tênis dura no máximo 3 meses, se as crianças tiverem cuidado dura até 4 meses. Mas não há reposição. E a gente tem que comprar um novo.

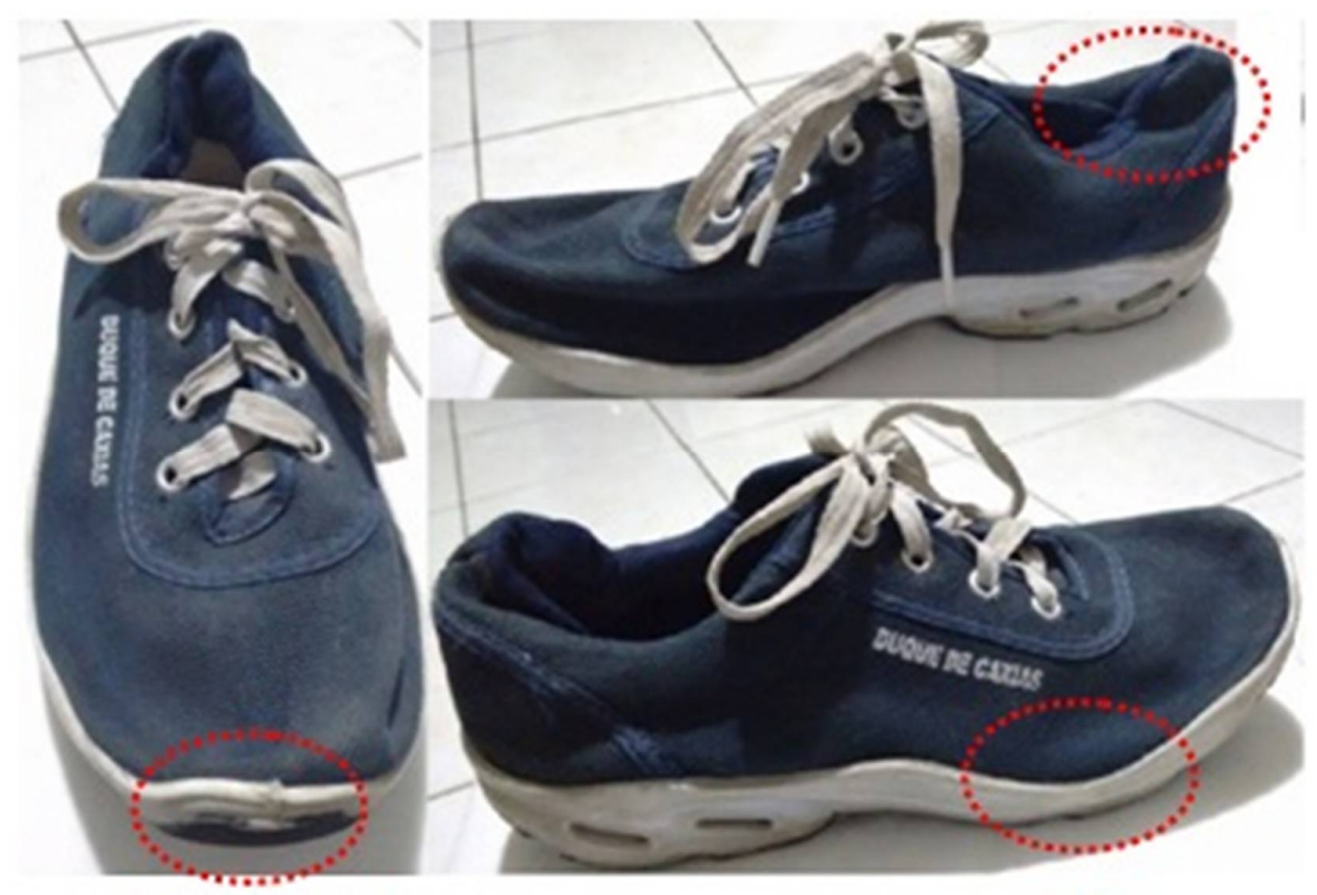

Figura 50 - Tênis escolar, distribuído por escolas do Município de Duque de Caxias no Rio de Janeiro, usado durante 3 meses, com previsão para uso de 12. 


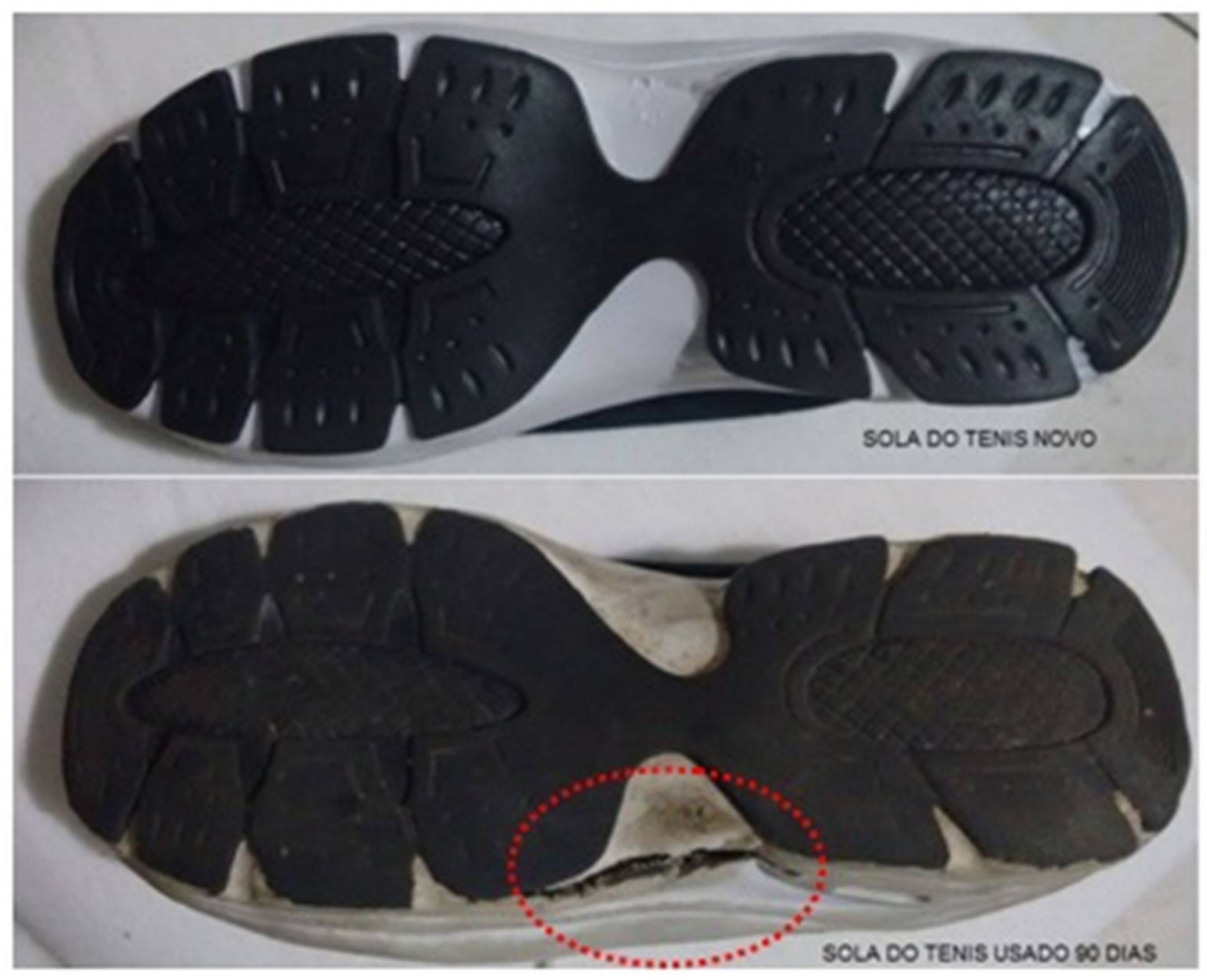

Figura 51 - Comparação visual entre a sola nova e a sola usada durante 90 dias, tênis tamanho 37-38, distribuído por escolas do Município de Duque de Caxias no Rio de Janeiro.

Em conclusão, com todas as exigências das especificações técnicas o tênis é fabricado para durar no mínimo o prazo de garantia estimado no CDC, que é de 6 meses. Quem tem poder de compra pode adquirir outro, mas os alunos do público-alvo deste sistema não podem. $O$ tempo de vida útil do tênis poderia ser expandido, com a manutenção que pode ser feita pelos sapateiros de bairro, desde que o projeto de produto estime esta possibilidade na configuração do modelo.

\subsection{9.}

\section{Requisitos desejados por alunos matriculados}

Os requisitos desejados é a demanda expressa pelos alunos, conforme resultados das entrevistas realizadas entre o ano de 2008-20015. O método de investigação da demanda dos alunos foi estruturado com base na ferramenta de Design Macroergonômico (DM), proposta por Fogliatto e Guimarães (1999). Os dados foram coletados por questionário, contendo perguntas relacionadas a dados demográficos e 2 do tipo aberta: $1^{\text {a }}$ pergunta: o que você espera de um calçado escolar? $2^{\text {a }}$. Pergunta: em qual calçado você pensou? 
Foram aplicados e coletados 480 questionários, com uma amostra de respondentes de alunos matriculados em escolas públicas, de ensino fundamental, do Estado do Rio Grande do Sul (nas cidades Porto Alegre e Novo Hamburgo), Rio de Janeiro e São Paulo, com idade entre 7 e 11 anos, no horário escolar: diurno, durante o verão. A amostra foi definida pelo tipo: "a que tivemos acesso". A distribuição das escolas visitadas, por número de respondentes, é apresentada na figura 52.

\begin{tabular}{|l|r|}
\hline $\begin{array}{l}\text { Regiões do Brasil, número de escolas e turmas “a que tivemos } \\
\text { acesso" do ensino fundamental da rede pública (Período escolar: } \\
\text { diurno). }\end{array}$ & $\begin{array}{l}\text { Número de } \\
\text { respondentes }\end{array}$ \\
\hline $\begin{array}{l}\text { São Paulo - Comunidade de Interlagos } \\
\text { (4 turmas de ensino fundamental = 2 escolas) }\end{array}$ & 164 \\
\hline $\begin{array}{l}\text { RS - Novo Hamburgo } \\
\text { (3 turmas, sendo: 2 na Escola Municipal Nilo Peçanha, e 1 na escola } \\
\text { Estadual Otavio Rosa). }\end{array}$ & 123 \\
\hline $\begin{array}{l}\text { RS - PORTO ALEGRE } \\
\text { (2 turmas de ensino fundamental = 1 escola }\end{array}$ & 115 \\
\hline $\begin{array}{l}\text { RJ - Rio de Janeiro } \\
\text { (2 turmas = Escola Municipal Cervantes) }\end{array}$ & 78 \\
\hline Total de respondentes & 480 \\
\hline
\end{tabular}

Figura 52 - Distribuição de escolas por número de respondentes

- A amostra da cidade de São Paulo foi de: 164 alunos, matriculados em escolas municipais, localizadas na comunidade do bairro de Interlagos. $\mathrm{O}$ acesso foi garantido através de um amigo, José Carlos de Ibualamo, coordenador de um Espaço Educativo - ensino de informática, sem fins lucrativos.

- A amostra da cidade do Rio de Janeiro foi de: 78 alunos, matriculados na Escola Municipal Cervantes, no bairro de Bento Ribeiro. O acesso foi garantido porque foi a escola na qual a pesquisadora estudou.

- A amostra coletada no Estado do Rio Grande do Sul foi de: 238 alunos, sendo 123 na cidade de Novo Hamburgo e 115, na cidade de Porto Alegre. O acesso na Escola Otávio Rosa, em NH, foi permitido porque a filha da pesquisadora era aluna na época. Já na escola de Porto Alegre, a mãe de uma das bolsistas do Projeto Fábrica da Inclusão, da UFRGS, era diretora da escola.

- A numeração dos pés para calce apresentada pela amostra: do número 27 ao número 41.

Os resultados dos itens mais citados pelos alunos entrevistados foram: 
- Resposta da $1^{\mathrm{a}}$ pergunta quanto a gênero: os meninos e as meninas responderam, nesta ordem: esperam que o calçado seja confortável, bonito e macio.

- Quanto à $1^{\mathrm{a}}$. pergunta, o total das respostas mostram que os alunos desejam, nesta ordem: conforto, beleza e maciez para um par de calçados (Figura 54).

\begin{tabular}{|c|l|}
\hline $\begin{array}{l}\text { Ordem de } \\
\text { importância do } \\
\text { item citado }\end{array}$ & $\begin{array}{l}\text { Demanda das crianças: } \\
\text { o que você espera de um calçado escolar? }\end{array}$ \\
\hline 1 & Confortável \\
\hline 2 & Bonito \\
\hline 3 & Macio \\
\hline 4 & Com Mola (amortecedor) \\
\hline 5 & Bom \\
\hline 6 & Da Nike \\
\hline 7 & Com Rodinhas \\
\hline 8 & Que Sirva no pé \\
\hline 9 & Estiloso \\
\hline 10 & Allstar \\
\hline
\end{tabular}

Figura 53 - Ordem de citação das respostas dos 480 respondentes para a $1^{\text {a }}$.

Foi possível organizar os dados da demanda dos alunos por série escolar, pelo total de respondentes (480), de todas as escolas a que tive acesso (figura 54):

\begin{tabular}{|c|l|l|l|l|l|}
\hline $\begin{array}{c}\text { Ordem de } \\
\text { importância do } \\
\text { item citado }\end{array}$ & \multicolumn{1}{|c|}{$\mathbf{3}^{\text {a. Série }}$} & $\mathbf{4}^{\text {a }}$ Série. & \multicolumn{1}{|c|}{$\mathbf{5}^{\text {a. Série }}$} & \multicolumn{1}{|l|}{$\mathbf{6}^{\text {a }}$ Série } & $\mathbf{8}^{\text {a }}$ Série \\
\hline 1 & confortável & confortável & confortável & bonito & confortável \\
\hline 2 & bonito & bonito & bonito & bom & bonito \\
\hline 3 & macio & estiloso & da Nike & com mola & macio \\
\hline 4 & que sirva no pé & com mola & estiloso & macio & com rodinhas \\
\hline 5 & Bom & não machuca & bom & confortável & com mola \\
\hline 6 & Rosa & da Nike & Allstar & de marca & Allstar \\
\hline 7 & $\begin{array}{l}\text { com } \\
\text { amortecedor }\end{array}$ & que dure & que dure & allstar & não machuca \\
\hline 8 & salto alto & Allstar & da Adidas & da Sandy & da Nike \\
\hline 9 & com rodinhas & macio & preto & da Nike & bom \\
\hline 10 & cano longo & com rodinhas & barato & da Adidas & da Adidas \\
\hline
\end{tabular}

Figura 54- Distribuição de demanda por série escolar.

Quanto à $2^{\mathrm{a}}$ pergunta: em qual calçado você pensou? Em relação às crianças que vivem em cidades maiores como, São Paulo e Rio de Janeiro, esperava-se considerações regionais, mais ainda, questões relacionadas à formatação dos 
brandings de moda, apresentados pelos outdoors ao longo do caminho urbano dessas crianças, no percurso casa-escola-casa.

Houve surpresa com as crianças paulistas, apesar de morarem no final da via Interlagos (cidade de São Paulo), cheia de outdoors fixados. Elas desejavam um tênis super barato, denominado por elas de tênis Society. Como elas mesmas descreveram: o tênis é o bixo! Dá para ir à escola, jogar futebol e passear, e ainda custa só $R \$ 24,90$.

As crianças do Rio de Janeiro também surpreenderam, não citaram marcas como "desejos". Disseram que gostariam de calçados que não queimassem o pé no sol, e que não furassem, com cacos de vidros, quando passavam nas portas dos bares. Ainda disseram que não desejavam tirar as tampinhas, de cerveja e refrigerantes, que ficavam presas no solado.

Na cidade de Porto Alegre sim, citaram marcas como Nike, Mizuno, Allstar e muitas referências com os times de futebol de preferência, como o Internacional e o Grêmio. É possível perceber tal inclinação, com os gaúchos, a tradição define: ou tu és colorado (torce pelo internacional) ou tu és gremista (torce pelo grêmio). E alguns ainda dão outra opção: tu escolhes peão - ou tu és colorado, gremista ou pelotense. O pelotense relembra os filhos dos donos de charqueadas que voltaram "aviadados" (citação local) pela educação europeizada.

Esperava-se que a opinião das crianças de Novo Hamburgo fossem enviesadas pelo fato delas viverem o mundo da fabricação de calçados, controlado pelo tempo e padronização do trabalho, taylorista/fordista e, também, pelo que é omitido e diluído pelos discursos políticos: o trabalho infantil na cidade. A hipótese foi confirmada, pois as crianças disseram que desejavam um calçado "sem defeitos". Contudo o modelo definido pela maioria das crianças foi tênis.

Algumas mães também foram ouvidas, e a principal preocupação é como manter o uniforme escolar, e mais uma vez, o tênis aparece como um dos componentes mais caros e mais vulneráveis ao uso diário. As mães dizem que o tênis não dura mais que três meses, nos pés de chumbo dos filhos, porque eles não são usados somente para irem à escola:

É um tênis para tudo. E para comprar, de três em três meses, não há condições financeiras. $O$ que se consegue é alternar o seu uso com chinelos: no inverno usam os tênis e no verão as crianças vão de chinelo, já que é calor mesmo. 
Os itens mais citados pelos alunos foram triados por fatores práticos e correlacionados com as Normas especificas que definem seus parâmetros no calçado (figura 55).

\begin{tabular}{|c|l|r|l|}
\hline \multicolumn{3}{|c|}{ Requisitos desejados pelos alunos que definem o fator Prático e sua relação com as } \\
Normas \\
$\begin{array}{l}\text { Ordem de } \\
\text { citação }\end{array}$ & ltens citados por ordem de importância & Norma \\
\hline 1 & Confortável & 7,67 & ABNT NBR 14834 \\
\hline 2 & Macio & 4,9 & $\begin{array}{l}\text { ABNT NBR 14836 } \\
\text { ABNT NBR 14838 } \\
\text { ABNT NBR 16037:2015 }\end{array}$ \\
\hline 4 & Que sirva no pé & 3,83 & ABNT NBR 14839 \\
\hline 6 & Com Amortecedor & 1,83 & ABNT NBR 14838 \\
\hline 7 & Solado duro para não grudar chapinha & 1,5 & $\begin{array}{l}\text { ABNT NBR 148737 } \\
\text { ABNT NBR 148738 }\end{array}$ \\
\hline 9 & de garrafa & 1,5 & $\begin{array}{l}\text { ABNT NBR } 14742 \\
\text { ABNT NBR 151171 }\end{array}$ \\
\hline 15 & Com & 0,75 & ABNT NBR 15172 \\
\hline 21 & De couro para ficar mais bonito & 0,33 & ABNT NBR 14742 \\
\hline 24 & De brim & 0,2 & ABNT NBR 16037 \\
\hline
\end{tabular}

Figura 55 - Requisitos desejados pelos alunos que definem o fator Prático e sua relação com as Normas.

Em conclusão, as análises auxiliaram a construir uma ficha técnica, conforme figura 56, onde estão dispostos os requisitos obrigatórios e desejados para orientar o projeto de produto do calçado escolar. Esta proposta difere do modelo apresentado pelo projeto da Norma porque levou em consideração: a) os resultados da análise comparativa entre os itens do Projeto da Norma com as estratégias de ecodesign (Brezet e Van Hemel, 1997); b) com os desejos e necessidades dos alunos; e c) as exigências da empresa focal para garantir os atributos de natureza técnica e ambiental de forma a não frustrar a competitividade entre as empresas ou grupos sociais produtivos participantes nos territórios ou entre eles. 


\begin{tabular}{|c|c|c|c|}
\hline \multicolumn{4}{|c|}{ Ficha técnica para orientar o método em design do calçado escolar } \\
\hline \multicolumn{3}{|c|}{ No. de descrição das partes do calçado } & Norma que atende \\
\hline \multicolumn{3}{|c|}{\begin{tabular}{|l|l|} 
Forma & Esculpir sob as informações dos alunos na \\
matricula escolar. Usar para a modelagem \\
e não usar no processo para fabricação.
\end{tabular}} & $\begin{array}{l}\text { ABNT NBR 16260, Conforto de } \\
\text { calçados - Fôrmas infantis. } \\
\text { •ABNT NBR 15159, Conforto de } \\
\text { calçados e componentes - Formas. }\end{array}$ \\
\hline \multicolumn{4}{|c|}{$\begin{array}{l}\text { Modelo } \\
\text { Tênis conforme o desejado pelas crianças. Não possuir tantas partes. Não há couraça } \\
\text { e nem contraforte. A palmilha interna foi excluída, considerando que a espessura da } \\
\text { palmilha de montagem (sistema de ensacamento) tem a função de manter a } \\
\text { estabilidade do tênis e a percepção de conforto no contato do pé com a palmilha. }\end{array}$} \\
\hline 2 & $\begin{array}{l}\text { Cabedal } \\
\text { Modelado com poucas partes. } \\
\text { Montado ao solado com costura, tipo } \\
\text { ponto celeiro, contribui à reciclagem. }\end{array}$ & \multirow{5}{*}{\multicolumn{2}{|c|}{$\begin{array}{l}\left({ }^{\star \star \star}\right) \\
\text { ABNT NBR } 14835 \text { - Determinação da } \\
\text { massa. } \\
\text { ABNT NBR } 14837 \text { - Determinação da } \\
\text { temperatura interna. } \\
\text { ABNT NBR } 16037: 2015 \text { - determinação } \\
\text { de conforto em componentes para } \\
\text { calçados; } \\
\text { ABNT NBR } 12834 \text { - Determinação da } \\
\text { permeabilidade } \\
\text { Requisitos de substâncias restritivas - } \\
\text { Materiais em que há contato direto } \\
\text { com a pele } \\
\text { 1. Chumbo Solúvel - EN } 71 \\
\text { 2. Chumbo Total - ABNT NBR 16268 } \\
\text { 3. Cádmio Solúvel - EN } 71 \\
\text { 4. Cádmio Total - ABNT NBR 16268 } \\
\text { 5. Formaldeído - ISO } 17226 \text { (couro) e } \\
\text { ISO 14184-1 (tecido) } \\
\text { 6. Cromo VI - ISO 17075 (couro) }\end{array}$}} \\
\hline 3 & $\begin{array}{l}\text { Lingueta } \\
\text { Proteção do peito do pé na zona de } \\
\text { fechamento. }\end{array}$ & & \\
\hline 4 & $\begin{array}{l}\text { Forro } \\
\text { Entre usar o forro ou o debrum, é } \\
\text { melhor o forro, que poderá ter duas } \\
\text { funções: resistência ao cabedal e } \\
\text { percepção de conforto do pé com a } \\
\text { área interna do calçado. }\end{array}$ & & \\
\hline 5 & $\begin{array}{l}\text { Costuras } \\
\text { Costuras suficientes para unir as } \\
\text { partes e permitir resistência ao } \\
\text { rasgamento. Linha usada para ponto } \\
\text { celeiro: costura manual com linha } 8 \\
\text { ou 6, encerada. }\end{array}$ & & \\
\hline 6 & $\begin{array}{l}\text { Palmilha de montagem } \\
\text { Fazendo o papel funcional da } \\
\text { palmilha interna e da sobre palmilha. }\end{array}$ & & \\
\hline 7 & $\begin{array}{l}\text { Solado } \\
\text { Apenas solado com a função de não } \\
\text { escorregar, e demais das normas. }\end{array}$ & \multicolumn{2}{|r|}{$\begin{array}{l}\left({ }^{\star \star *}\right) \\
\text { ABNT NBR } 14838 \text { - Índice de } \\
\text { amortecimento; } \\
\text { ABNT NBR } 14839 \text { - Índice de pronação; } \\
\text { ABNT NBR } 14840 \text { - Percepção de calce e } \\
\text { marcas no pé; } \\
\text { ABNT NBR } 14738 \text { - Resistência ao } \\
\text { desgaste por abrasão; } \\
\text { ABNT NBR } 14739 \text { - Determinação da } \\
\text { deformação; } \\
\text { ABNT NBR } 15275 \text { - Ensaios biológicos - } \\
\text { Palmilha, laminados sintéticos e solados } \\
\text { - Determinação da resistência ao. } \\
\text { ataque microbiano. }\end{array}$} \\
\hline & & & \\
\hline
\end{tabular}

Figura 56 - Ficha Técnica com propostas de requisitos obrigatórios para o método em design do calçado escolar com referência na análise do Projeto em relação à Norma específica ao calçado escolar. 


\subsubsection{0. \\ Projetação por grupos sociais produtivos em Caxias e Novo Hamburgo}

Nesta fase do método em design, o calçado escolar deve ser desenvolvido até o protótipo, por grupos sociais produtivos de diferentes territórios com base nos requisitos obrigatórios definidos no passo anterior e apresentados na figura 56. Dois territórios foram selecionados para estudo de campo desta tese, um grupo de Cidade Caxias (RJ) e outro de Novo Hamburgo (RS), e o propósito foi identificar se eles podem atender as exigências da Empresa focal. Deve-se notar que na fase de investigação quanto à mão de obra e oferta de insumos em cada território, foi realizado um encontro com o grupo social produtivo esclarecendo sobre os propósitos do sistema, peculiaridades do processo de desenvolvimento e fabricação do calçado como: atender as especificações técnicas, normas regulamentadoras do Ministério do Trabalho e atender as dimensões da sustentabilidade, sem deixar de satisfazer as necessidades dos usuários.

Para a confecção do tênis escolar, cada grupo social produtivo deve montar a matriz de oportunidades de projeto (necessidades) x matéria-prima com os recursos disponíveis no local. As necessidades estão relacionadas com os itens citados pelos alunos matriculados nas escolas do território, quanto ao clima, à capacidade de fabricação com o uso daquela matéria-prima. A matéria-prima é a encontrada no local para confecção do calçado. A matriz (figura 57) deve ser construída colocando na primeira linha as necessidades que cada material deverá atender; na $1^{\mathrm{a}}$ coluna a parte do calçado; na $2^{\mathrm{a}}$ coluna a proposta do material; na $3^{\mathrm{a}}$ coluna indicar se o material atende tal necessidade listada na primeira linha, o local onde será comprado, se no território ou próximo, e as propriedades do material conforme as especificações técnicas. Além disso, descrever quais os componentes que se mostraram atendendo todos os fatores do produto (funcional, estético, simbólico e ambiental), mas que não foi possível listar porque exigia desenvolvimento tecnológico, portanto não encontrado no mercado tradicional, na cadeia de fornecedores de insumos. 


\begin{tabular}{|c|c|c|c|c|c|c|}
\hline \multirow[b]{2}{*}{$\begin{array}{l}\text { Partes } \\
\text { do } \\
\text { calçado }\end{array}$} & \multicolumn{6}{|c|}{ Indicação de matéria-prima/componente } \\
\hline & Por gênero & $\begin{array}{l}\text { O chão é } \\
\text { quente }\end{array}$ & $\begin{array}{l}\text { Muita } \\
\text { lama }\end{array}$ & $\begin{array}{l}\text { Calçado } \\
\text { para sair } \\
\text { também? }\end{array}$ & cor & $\begin{array}{l}\text { Chove } \\
\text { muito }\end{array}$ \\
\hline \multirow[b]{2}{*}{ Modelo } & Ex.menina Allstar & & & & & \\
\hline & $\begin{array}{l}\text { Ex. Menino } \\
\text { Society }\end{array}$ & & & & & \\
\hline \multirow{2}{*}{ Cabedal } & menina & & & & & \\
\hline & menino & & & & & \\
\hline \multirow{2}{*}{ Solado } & menina & & & & & \\
\hline & menino & & & & & \\
\hline
\end{tabular}

Figura 57 - Modelo de matriz para definição de matéria-prima em relação aos fatores práticos citados pelos alunos.

Com a matriz de componentes montada, a próxima matriz é a matriz morfológica (figura 58) onde são realizadas as diversas combinações entre os componentes propostos para cada parte do calçado em relação ao solado e os meios e processos de fabricação. Os resultados desta matriz serão os vários modelos possíveis de tênis escolar para aquele território.

\begin{tabular}{|l|l|l|l|}
\hline \multicolumn{3}{|l}{ Matriz morfológica para definir opções de modelo do calçado escolar } \\
\hline $\begin{array}{l}\text { Partes do calçado } \\
\text { escolar }\end{array}$ & Opção 1 & Opção 2 \\
\hline 1 & Forma do calçado & Imagem (isométrica) & Imagem (isométrica) \\
\hline & Lingueta & Imagem componente & Imagem componente \\
\hline 2 & Forro & Imagem componente & Imagem componente \\
\hline 3 & Costuras & Tipo de linha e imagem & Tipo de linha e imagem \\
\hline 4 & Palmilha montagem & Tipo de componente & Tipo de componente \\
\hline 5 & Solado & Imagem solado & Imagem solado \\
\hline 6 & $\begin{array}{l}\text { Processo de } \\
\text { montagem }\end{array}$ & $\begin{array}{l}\text { Descrever processo de } \\
\text { montagem }\end{array}$ & $\begin{array}{l}\text { Descrever processo de } \\
\text { montagem }\end{array}$ \\
\hline $\begin{array}{l}\text { DESENHO/ESBOÇO } \\
\text { DA OPÇÃO }\end{array}$ & Desenho opção 1 & Desenho opção 2 \\
\hline
\end{tabular}

Figura 58 - Matriz morfológica para definir opções de modelo do calçado escolar

Deve-se notar, no entanto, que se fosse um processo de compra verdadeiro, deveria ser levado em consideração a aplicação dos ensaios técnicos de laboratório no protótipo escolhido e realizado os protocolos de avaliação de sustentabilidade como a Matriz SQC. Em seguida, seus resultados deveriam ser discutidos com os grupos sociais produtivos participantes do sistema de produção do calçado escolar no território. Os resultados da projetação em Novo Hamburgo e Duque de Caxias são apresentados a seguir. 


\subsubsection{1.}

\section{Resultados da Projetação em Novo Hamburgo}

O grupo social produtivo de Novo Hamburgo ficou formado pela Incubadora Popular de Novo Hamburgo, as artesãs manuais cadastradas na incubadora, o fórum de economia solidária, o grupo esperança do CRAS, um sapateiro convidado, um modelista de calçados e uma fabriqueta do Bairro Canudos e a pesquisadora (representando a Universidade). Contou também com as entidades de classe que se ofereceram para dar suporte como: a Assintecal e os sindicatos dos trabalhadores, bem como o movimento social local para a economia solidária. Contudo apresentou-se por uma iniciativa de implementação (neste caso de experimento) por aglomerados de agentes sociais, no formato de rede de atores do tipo THDS, composta pelo governo, as empresas, a universidade e a comunidade. Um formato igual ao do capital social nacional, porém com iniciativa de implementação do SPPD diferente, mostrando uma alteração no papel dos atores:

1. Não há empresa focal e sim Unidade Executora (UEx) que represente o aglomerado de agentes sociais, neste caso de NH é representada pela Incubadora da Prefeitura, nas pessoas dos Gestores Neca e Alex.

2. O governo, representado pela Prefeitura Municipal, em primeiro momento, participa como apoiador administrativo à ação da Incubadora, entendida como experimental. Futuramente, já está se discutindo a presença da prefeitura como agente de fomento e apoio político às ações do projeto, especialmente junto as empresas fabricantes de insumos, através de suas Entidade de Classe.

A participação do Governo, como Empresa focal, tomando iniciativa à implantação do sistema em parceria com demais Secretarias como a de educação, não foi possível, pela dificuldade em apresentar o projeto à Secretaria de Educação Municipal. Por este motivo foi construído, estrategicamente, um atalho pela Incubadora Popular para o experimento.

3. As empresas fornecedoras de insumos são representadas pela ASSINTECAL;

4. As empresas fabricantes são as MPE’s ou fabriquetas de bairro;

5. A comunidade é representada pelas habilidades locais das artesãs da economia solidária, pelos modelistas de calçados e solados que não são cadastrados como empresas. Os fóruns de movimentos sociais são representados pelo Fórum de Economia Solidária e pelo Sindicato dos trabalhadores das Indústrias de Calçados.

Esta formação pode ser dividida em três grupos sociais produtivos para atender o estágio de urgência da problemática do calçado escolar na cidade de 
Novo Hamburgo, e dar continuidade às atividades do sistema no local até atingir um estágio sustentável, gerando trabalho e renda: 1) a incubadora, os sapateiros locais, o modelista (Sr. Fernando), a pequena empresa fabricante e sua cadeia de suprimentos locais, 2) as artesãs, o grupo esperança do CRAS, a incubadora com seu potencial político-social para construir a cadeia de suprimentos, por parceria, e os sapateiros locais e 3) a fabriqueta e o modelista.

O grupo reuniu-se, a primeira vez, para receber a ficha técnica para o desenvolvimento do protótipo, definir a cadeia de suprimentos e os processos de fabricação. A reunião também serviu para discussão dos conceitos envolvidos na ficha técnica orientativa (figura 56). Os Itens questionados pelo grupo no 10. encontro foram:

1. O Dono da fabriqueta: $O$ solado só pode ser em TR? Tem o PVC que é mais baratinho e resolve o problema e ainda é mais macio para costurar a mão.

2. O Gestor da Incubadora: Precisa ser costurado à mão? Podemos conseguir ateliês só para fazer costura blaque. Ligaram na hora e perguntaram o preço do par: $\mathrm{R} \$ 0,65$ centavos.

3. As artesãs: não vamos costurar em máquinas, precisamos costurar a Mão. Não temos máquinas em casa.

4. O Dono da fabriqueta: na fábrica não tem mistério, podemos fazer costura blaque. Não podemos colocar mais uma costurinha no cabedal? Vamos tentar aproveitar mais o material, assim perde muito dinheiro.

5. O modelista (Sr. Fernando): explicou o conceito do calçado para o Dono da fabriqueta.

6. Uma das artesãs com experiência na fabricação de calçados: Mas sem estrutura não vai dar certo.

7. O modelista (Sr. Fernando): Você já tentou?

8. Um sapateiro convidado: esse sapato não dá lucro para as empresas, não tem nada nele.

9. A técnica da incubadora: mas não polui nossa cidade e do mesmo jeito gera emprego e trabalho para as fábricas e para as pessoas. Tem o suficiente. Precisamos testar.

10. O dono da fabriqueta: Mas pela minha experiência não vai dar certo. As crianças não gostam de tênis assim.

11. As artesãs: assim como? não vimos ainda. Vamos tentar disse o modelista.

12. O sapateiro convidado: bom pode ficar, não sei se vai ter resistência para o uso na escola. Tem que achar material de boa qualidade.

13. As artesãs: aqui na incubadora tem muito material resíduo de boa qualidade que dá pra fazer. É só selecionar como está escrito na ficha. 
14. A assistente social do CRAS, responsável pelo grupo esperança: enquanto isso vamos motivando o grupo do CRAS com oficinas, como aquelas já realizadas pela Ronise. Porque nosso grupo tem interesse, mas tem outras questões para resolver, então por hora as oficinas são de grande valia. O único problema é o solado, porque elas querem fazer e usar o calçado que fazem ou dar para os filhos. Nas oficinas anteriores utilizamos chinelos usados como solado. Podemos ir trabalhando habilidades com o cabedal.

O grupo combinou tentar orçamentos para fazer solados mais envolventes ao cabedal e procurar no mercado se havia alguma opção. O modelista ficou responsável por buscar alternativas de solados já comercializadas no mercado. A pesquisadora ficou responsável por tentar, junto a ASSINTECAL, alguma indicação de Empresa para solução do solado.

Foi contatada, por indicação da ASSINTECAL, a Empresa GRAVASUL, para que fosse desenvolvido um solado para experimento de calce por uma amostra de alunos de novo Hamburgo. Foram feitas tentativas de desenvolver um protótipo do solado, por prototipagem rápida ou impressão 3D, mas concluiu-se que a resina macia não iria aguentar o experimento com os alunos (calce).

A opção seria, então, fazer uma matriz e injetar para teste, que significa um investimento financeiro de 20 mil reais para: a prototipagem do solado, em material rígido, até ajustar o visual do modelo de solado; fabricar uma matriz de injeção dos pares de solado de acordo com o material a ser fabricado e injetar os pares de solados para fabricação de um grupo de amostras. A matriz e modelagem do visual do solado foram os vetores de maior custo, perfazendo um total de 10 mil reais.

O grupo social produtivo convidou a Empresa para participar do sistemapiloto, mas eles disseram que não poderiam, em função dos valores/hora dos profissionais que iriam executar o trabalho e todos os custos que envolvem a fabricação de uma matriz.

Este resultado mostra que, mesmo em uma cidade polo calçadista, com grandes empresas para fabricação de solados e com tecnologia de ponta para esse trabalho, há necessidade de motivar inovações tecnológicas no território, conforme proposta do SPPD.

As pequenas empresas não possuem condições financeiras para desenvolver uma matriz de solados somente para experimento. Um processo de desenvolvimento tecnológico em parceria, neste território, poderia contribuir 
com a indústria calçadista e demais empreendimentos para ampliar a capacidade de atendimento aos alunos, atendendo os requisitos obrigatórios relacionados aos fatores ambiental, funcional, simbólico e cultural do calçado brasileiro, de uma forma geral.

Em reunião com representantes da Incubadora Popular Municipal para formalização das atividades no local e apresentação do projeto detalhado do sistema-piloto, foram citados, também, os limitantes para o desenvolvimento tecnológico de produtos, como o solado. Mas os gestores apresentaram-se como parceiros em reduzir estes entraves, explicando, pelas palavras de Neca, (servidora pública) uma das técnicas do espaço:

Sem o solado vamos frustrar as pessoas envolvidas neste trabalho, principalmente os artesãos, se vamos experimentar o sistema-piloto devemos ir até a tangibilização do protótipo e o planejamento de opções de gerar renda, trabalho e construir um novo olhar para a incubadora, o de agregar inovação tecnológica às oficinas de artesanato que são atualmente realizadas aqui.

O gestor Alex, confirmou as palavras de Neca dizendo:

Não podemos é deixar de tentar.

Ronise (a pesquisadora) poderias nos apresentar um projeto detalhado para que possamos solicitar, junto a nossa Secretaria de Desenvolvimento Econômico, apoio financeiro para estas fases de desenvolvimento tecnológico do sistema-piloto? De qualquer forma, vamos juntos tentar parcerias com as empresas. De algum lugar vai sair. Senão vamos até onde conseguimos.

Desta forma, a Incubadora tornou-se a Empresa focal do sistema-piloto de novo Hamburgo, as solicitações já foram atendidas e as atividades do sistemapiloto oficializado.

O modelista (Sr. Fernando) chegou a um protótipo, conforme figura 59. E como agente do grupo social produtivo, formado por ele e a fabriqueta de Novo Hamburgo, relatou que:

O protótipo foi realizado com materiais já existentes no mercado. Deu trabalho para achar o solado. Primeiro achei o solado, depois desenvolvi a forma, depois a modelagem, a busca de materiais. Depois montei e desmontei tudo. Achei fácil. Agora vou montar outro de forma a tentar passar pelos ensaios de resistência das costuras e biqueira. Mas o modelo ficou bom.

E será possível manufaturar:

- sem forma.

- costura com linha de ponto celeiro.

- couro seria melhor, aquele camurção que falei. 
- o resíduo, estou achando complicado hein! Na hora de reciclar vai dar problema. Enfim!

- sola foi um parto, se é TR mesmo do bom não sei, confiei no que me venderam, mas o custo foi de $R \$ 2,50$ o par.

- o custo total deste tênis ficou em media: de 18,00 a 20,00 reais.

Ah! Não sei as artesãs ou o sapateiro ou o pessoal da fabriqueta, isso vai variar hein! Tempo de montagem: eu levei 1 hora. Mas foi bacana. Diferente e deu certo no visual. Agora vamos aos testes?

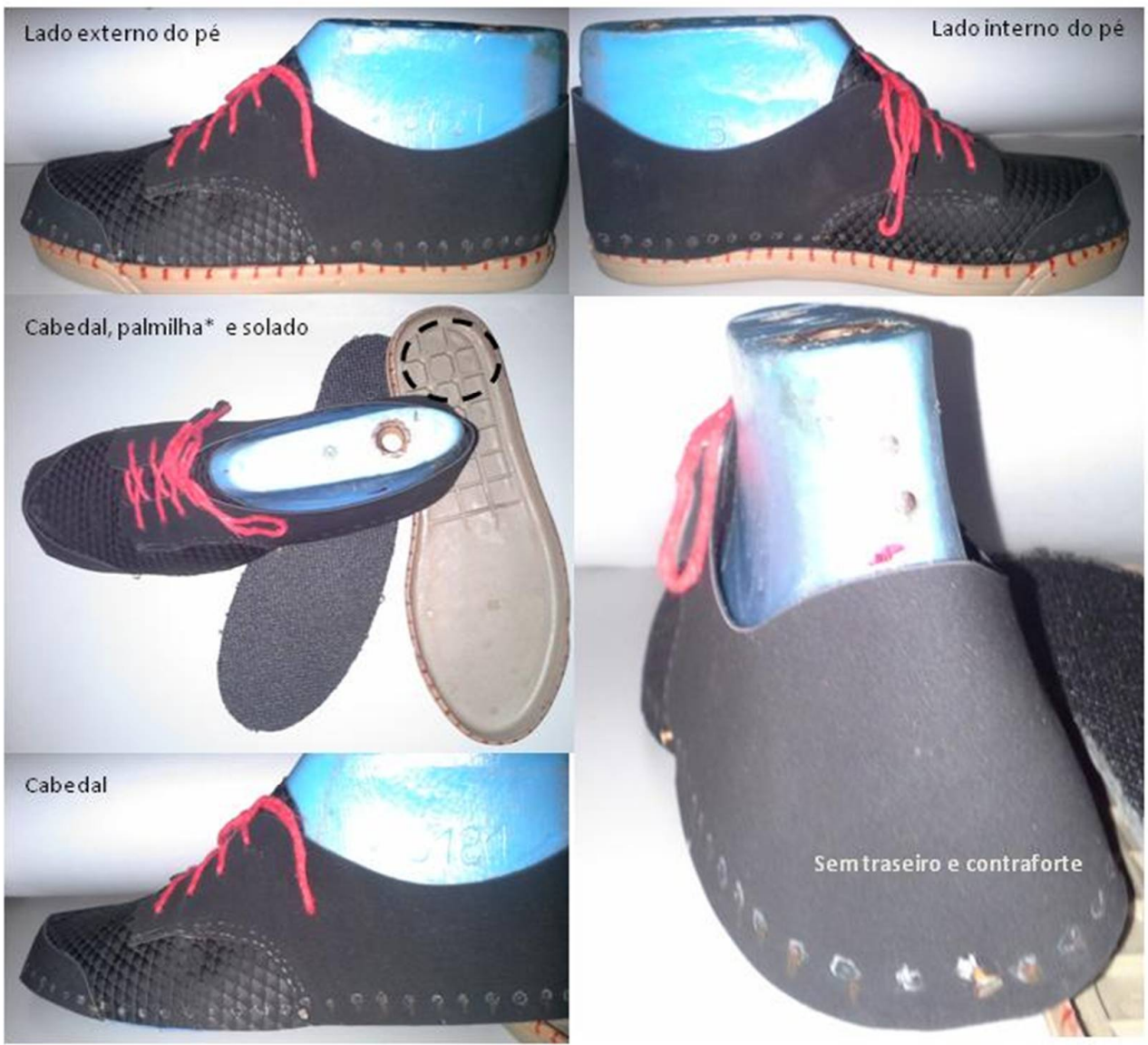

* $O$ solado foi comprado no mercado, com rouba peso, por isso a palmilha para proteção da sola do pé.

(_) Rouba-peso do solado.

Figura 59 - Protótipo apresentado pelo grupo social produtivo, formado pelo modelista e a fabriqueta de Novo Hamburgo.

Outra consideração quanto ao $\mathrm{Sr}$. Fernando (o modelista de calçados) vai de encontro ao que Albuquerque (2014) fala sobre cooperação, enquanto um processo que transforma o modo de pensar dos indivíduos, na medida em que as experiências positivas abrem possibilidade de continuidade da relação entre aqueles que participam. 
O Sr Fernando percebeu que através daquele processo de desenvolvimento de produto (calçado) compartilhado, ele conseguiria mais oxigênio para repensar suas ideias e tangibilizá-las em mais opções, e disse ele:

- Guria, tu nem sabe o que vou te mostrar, vai cair os butiá do bolso.... Olha este modelinho que já pensei para fazer com uma família, que tem uma fabriqueta em Canudos (bairro industrial de Novo Hamburgo). Olha isso guria...vai custar 10,00 reais na loja! (figura 60).

- A pesquisadora perguntou: como assim 10 reais na loja? Quais materiais?

- Não, não, não guria, vamos trabalhar juntos, o material é claro vai definir o custo final, mas já estamos pensando juntos em outras formas de produto, um melhorzinho, com opções de material melhor, porque este tem PVC na sola. Não é guria?, e daí não pode, NE guria?

E vamos propor para os skatistas.

Mas como sapato escolar ele poderia Tb? Guria a 10,00, escuta isso!

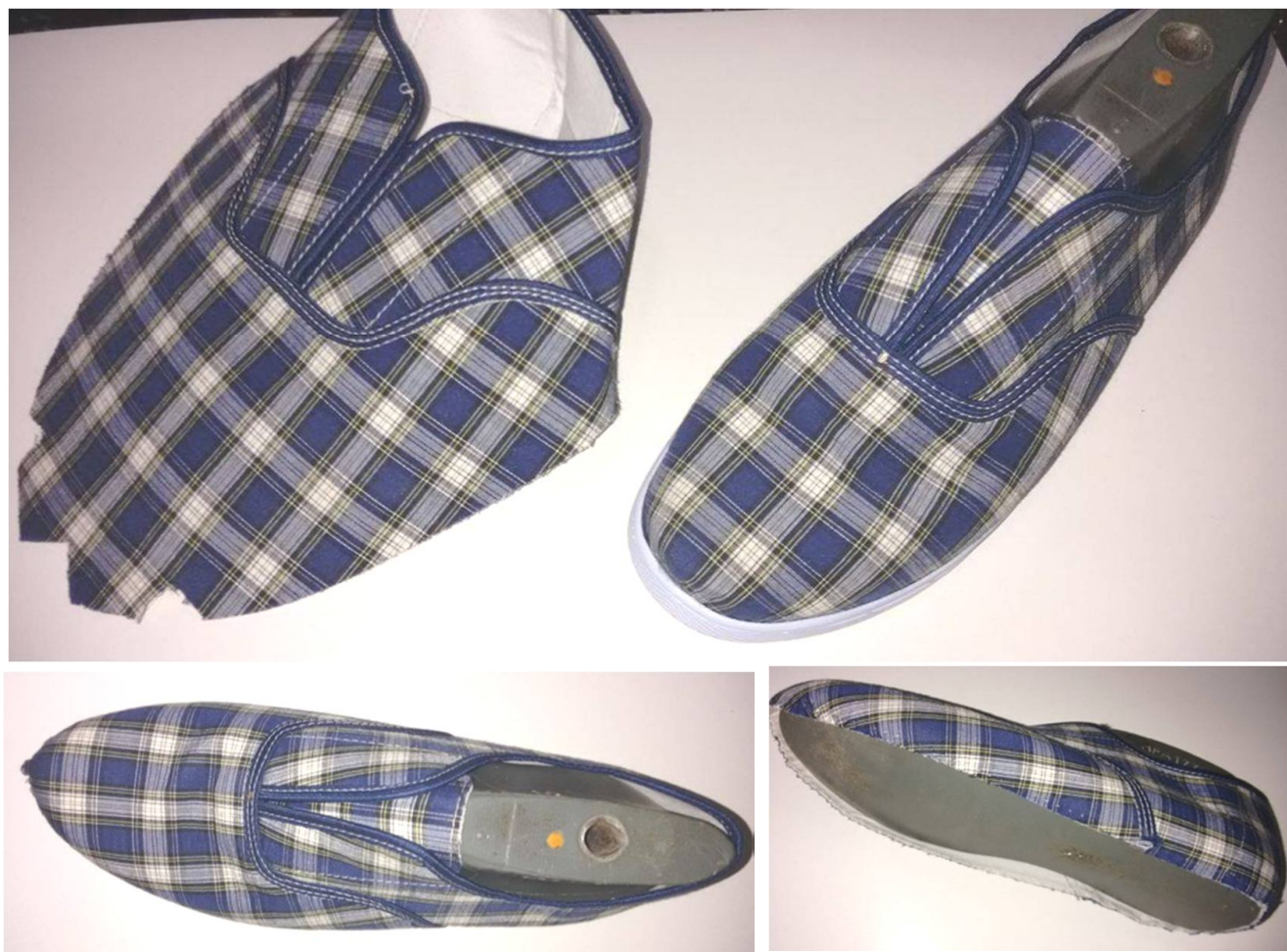

Figura 60 - Tênis desenvolvido pelo modelista, Sr Fernando, para fabricar com uma Família proprietária de uma fabriqueta em Canudos - Novo Hamburgo: definindo o $4^{\circ}$. grupo social produtivo do território.

O Sr Fernando construiu uma estratégia de negócio, pelo pensamento do produto, considerando o trabalho em grupo, necessariamente uma estratégia baseada nos diálogos e confrontos, nos debates que se fizeram, e ele foi buscar também fora, em outro grupo que ele potencializou, como a família dona da 
Fabriqueta. Isto mostrou que Novo Hamburgo formou 4 grupos sociais produtivos.

Este fato expressa o movimento da estrutura de inovação que é realizada por uma rede de atores, trabalhando em forma de engrenagem, impulsionados por uma estratégia de inovação tecnológica social (figura 6, capítulo II). Se os demais atores da rede, estivessem conscientizados a trabalhar no território, sob a lógica da THDS, já se constituiria um grupo produtivo real e operante.

Desta forma a figura 61 apresenta em fluxograma as fases do sistema de produção que o Grupo social produtivo de Novo Hamburgo alcançou. 


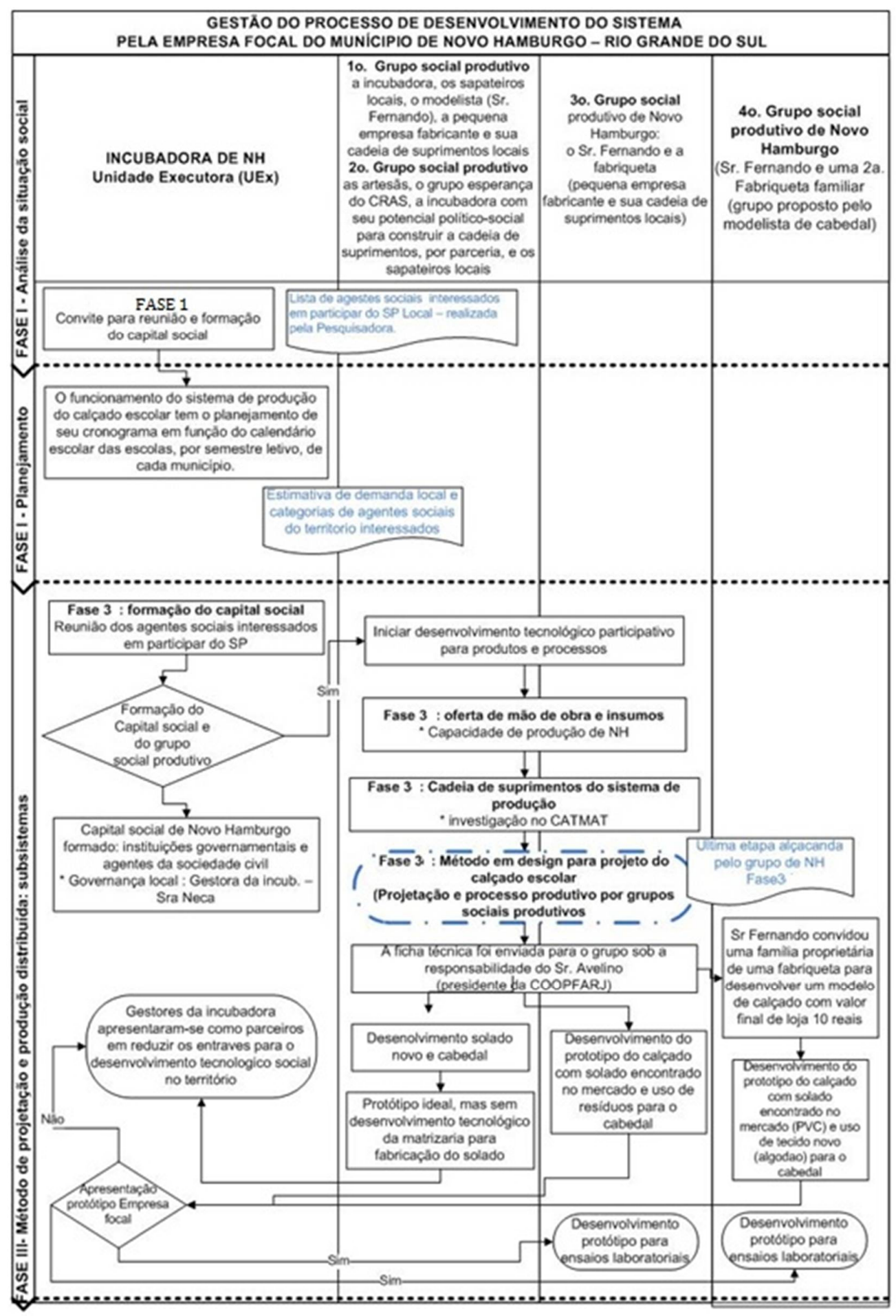

Figura 61 - Fluxograma do SPPD que o grupo social produtivo de Novo Hamburgo experimentou. 


\subsubsection{2.}

\section{Resultados da Projetação em Duque de Caxias}

Compreende-se como Grupo social produtivo do território de Duque de Caxias (RJ) a COOPFARJ - com o grupo de Empresas, representada pelo $\mathrm{Sr}$ Avelino, presidente da Cooperativa e representante do APL Lote XV.

Em email, o Sr. Avelino retornou dizendo: Preciso de um pouco de tempo para isso. Estou contatando o técnico e uma fábrica associada à Cooperativa. Lhe respondo o mais breve possivel.

Foram também feitas algumas tentativas de contato por telefone, e em todas, o Sr. Avelino disse: que está muito difícil, porque o modelo é muito diferente. E a sola não se encontra facilmente. E que as empresas acham que se fizerem estarão fazendo "porcaria" e queimando o filme delas. Mas ele ainda está tentando uma solução ou uma resposta.

Desta forma a figura 62 apresenta em fluxograma as fases do sistema de produção que o Grupo social produtivo de Duque de Caxias alcançou. 


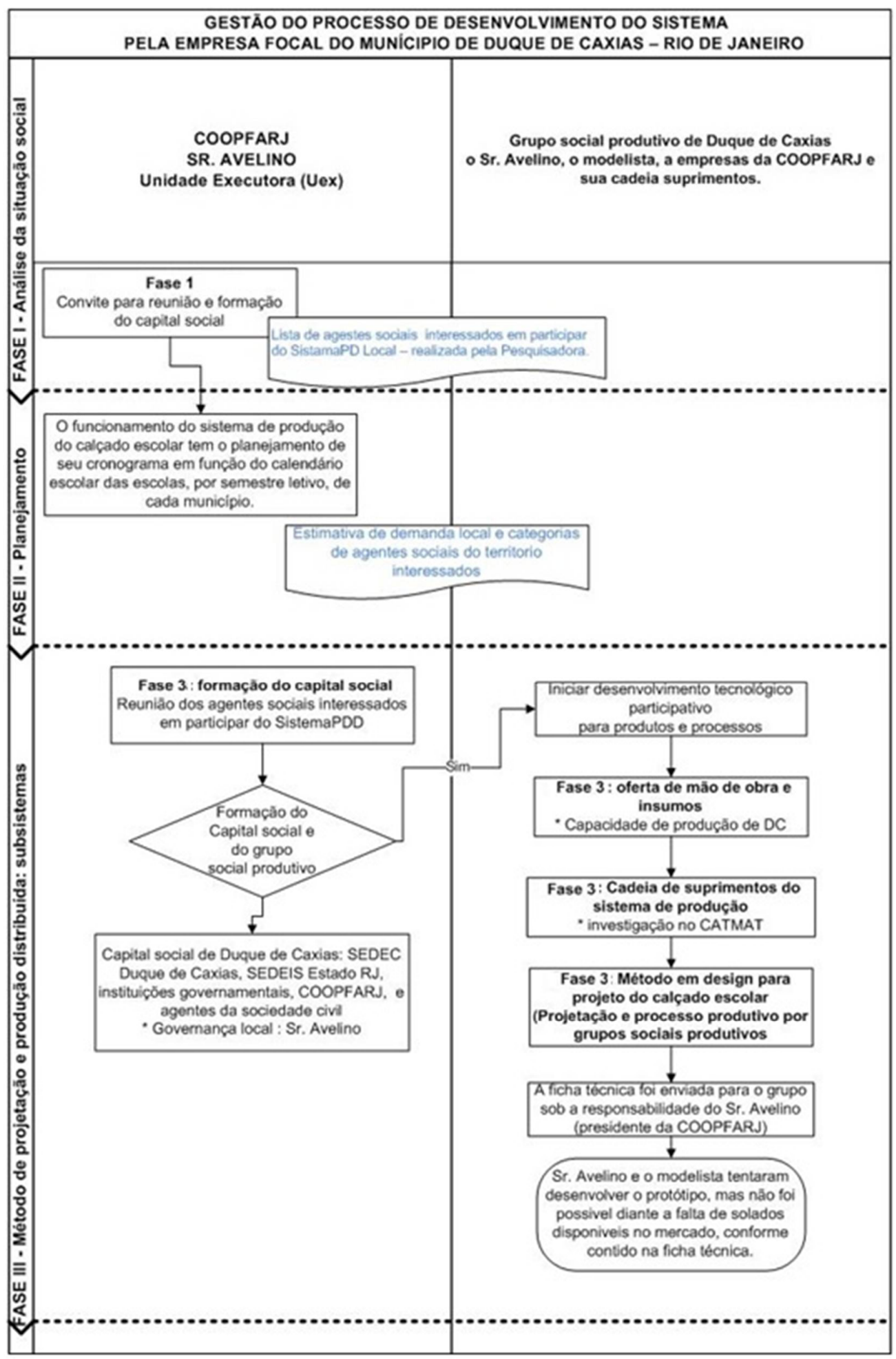

Figura 62 - Fluxograma das fases do SPPD que o grupo social produtivo de Duque de Caxias alcançou. 


\subsubsection{3.}

\section{Resultados alcançados pelo projeto-piloto do calçado escolar}

Os resultados mostram que a formação do capital social é o ponto mais crítico do sistema-modelo, principalmente em função de algumas dificuldades encontradas para solucionar questões técnicas e de projeto do produto, portanto de inovação tecnológica.

Nenhum dos grupos chegou à fase de "Aplicação da matriz morfológica para estimar configurações de produto, com base nos resultados da Matriz SQC”. O grupo de Novo Hamburgo inclusive alertou: fazer matriz é muito chato, isso é bom para designer. A gente faz na mesa e na cabeça a mesma combinação.

Os dois grupos não chegaram na fase que define o desenvolvimento dos protótipos de insumos (componentes) e seus testes de processos para fabricação dos produtos, e a fase de descrição final do projeto, quando são elaboradas as especificações técnicas que devem constar do Edital de Chamada pública para cadastro de fornecedores e fabricantes de componentes e produtos finais. Contudo, demonstraram interesse em chegar a uma solução possível nos seus territórios.

Mas o grupo de novo Hamburgo chegou a dois produtos, que deveriam ser repensado pelos demais do grupo social produtivo, mas com capacidade de realização dos ensaios laboratoriais (usou solado encontrado no mercado).

O território de Novo Hamburgo, apesar de ser um polo calçadista com todas as oportunidades de desenvolvimento tecnológico, mostrou entraves para a formação de parcerias necessárias ao desenvolvimento do solado. Seu grupo social produtivo ficou formado por empresas de pequeno porte e de artesãs manuais e de artesanato utilitário. Conseguiram também vincular a economia solidária como alternativa para as negociações entre os agentes produtivos. Além de formar seu capital social, descrever e estimar as fontes de componentes possíveis para formar a sua cadeia de suprimentos, conseguiu inserir o sapateiro como responsável pela manutenção dos calçados (para fazer os consertos). Mesmo com os entraves nas questões técnicas, foi mantido o interesse em continuar o desenvolvimento do sistema-piloto até atingir um ponto interessante ou bom, ou para desistir. Mas eles estão confiantes, como disse o gestor da Incubadora. 
No território de Duque de Caxias, no Rio de Janeiro, a luta para chegar a uma solução tangível dependeu somente do Sr Avelino. O resultado geral de pesquisa com o grupo de Duque de Caxias pode ser assim resumido: não conseguiram solucionar as exigências do solado e não possuem opções de componentes para definir "o que eles compreendem como resistência" do calçado, com os poucos componentes propostos para a projetação do modelo.

Neste sentido, o grupo não quer apresentar um modelo "porcaria", porque acham que irão perder crédito. O representante da Secretaria de desenvolvimento econômico de Duque de Caxias, explicou que não seria fácil um desenvolvimento tecnológico para o solado na região, apesar da boa vontade do Sr. Avelino. É preciso investir em tecnologia diz ele.

Em conclusão, pode-se dizer que, apesar dos grupos estarem familiarizados com a fabricação de calçados, ou seja, deterem o conhecimento tácito, não conseguem entender facilmente as especificações, operacionalizar as matrizes de projeto e desenvolver os protótipos naquilo que depende do conhecimento formal, e de inovação tecnológica. Há, portanto, necessidade de alocar, nos grupos, pessoas capacitadas que se responsabilizem pela parte técnica do projeto de produto e dos componentes mais complexos. Ou então, incentivar a capacitação nos locais onde estes grupos sociais produtivos estão localizados, como é caso de Duque de Caxias.

Os grupos formados tanto em Novo Hamburgo quanto em Duque de Caxias não têm os contatos necessários para a articulação com os fabricantes destes componentes, como é o caso, por exemplo, do solado, para desenvolverem inovação personalizada à situação problema estudada. Contudo, são especializados (conhecimento tácito) em identificar os insumos necessários que estão disponíveis no mercado. No entanto, isto não exclui a necessidade de ensaios laboratoriais para certificação conforme as exigências da Empresa focal.

Desta forma, fica claro que o sistema proposto não se sustenta sem um suporte técnico estruturado, sendo absolutamente necessária a participação de técnicos especializados, instituições de ensino e pesquisa na formação do capital social destes grupos e a parceria com as indústrias.

Assumindo que a configuração do capital social é crucial no modelo proposto, uma alternativa para garantir a fusão dos conhecimentos tácito e formal é que, no modelo, já esteja definido que a empresa focal (quer seja o governo, ou 
um grupo de aglomerados de agentes sociais) promova a parceria com cursos de design e/ou engenharia das regiões, porque então fariam parte dos grupos sociais produtivos enquanto agentes. Entidades como o SEBRAE ou outras que costumam atuar com consultoria em projetos e que tenham articulação com empresas fabricantes são importantes nesse processo de construir a rede de atores para atuar de forma estratégica, conforme item 3.1.3 do Capitulo III, e operacional. Talvez estas mediações sejam mais fáceis nos casos de territórios com formação de APLs, que, portanto, se mostram fundamentais para consolidação do sistema proposto.

\subsection{0.}

\section{Conclusão do Capítulo}

Este capítulo teve como propósito experimentar o sistema modelo para projetação e produção distribuída (SPPD) de produtos de atendimento básico, desenvolvido no Capitulo 3, considerando a problemática do calçado escolar do ensino público do Brasil.

Para descrever os resultados da experimentação do sistema-modelo considerou-se como referencia para as análises o que foi proposto como a hipótese desta tese: um sistema de produção distribuída, que congregue a indústria e os meios de produção local (artesanato utilitário) é uma solução para a fabricação de produtos de atenção básica de brasileiros de territórios diversos.

Desta forma, aceitar ou rejeitar a hipótese desta tese, dependerá do resultado das analises que serão realizadas para cada fase do sistema-modelo experimentado. A análise considerou:

1. o que foi proposto no SPPD;

2. como ficou configurada cada fase no experimento do calçado escolar considerando a instância nacional (governança federal), e os resultados nos municípios onde foram realizados os trabalhos de campo: Novo Hamburgo, no Estado do Rio Grande do Sul e Duque de Caxias, no estado do Rio de Janeiro.

3. os pontos fortes dos experimentos no atendimento ao modelo.

4. os pontos fracos dos experimentos no atendimento o modelo.

5. proposição de ajustes no modelo frente aos resultados das analises de cada fase. 
6. a contribuição do modelo para o campo do design social.

As análises foram realizadas no formato de tabela para melhor visualização da comparação entre os critérios considerados. Desta forma, a seguir, serão apresentadas 12 figuras, uma para cada Fase do experimento.

Em conclusão ficou identificado que a hipótese foi aceita, desde que as 23 propostas de ajustes ao sistema-modelo sejam realizadas. Também foram listadas 12 contribuições pontuais ao campo de ação do design social considerando suas competências estratégicas e operacionais no processo de planejamento e desenvolvimento de produto/ serviços. 
4.10.1.

Descrição dos resultados da Fase 1a: Situação social a ser atendida - a Indústria calçadista brasileira e a projetação, fabricação/distribuição do calçado escolar

O modelo propõe a descrição da demanda social ou a situação a ser atendida, para garantir que seja priorizada a investigação da situação a ser resolvida ao invés de tomar como parâmetro soluções já existentes

\begin{tabular}{|c|c|c|c|c|}
\hline social a ser atendida & & & & \\
\hline Demanda Nacional & Grupo de NH & Grupo DC & $\begin{array}{l}\text { Pontos fortes } \\
\text { (que atenderam ao modelo): }\end{array}$ & $\begin{array}{c}\text { Pontos fracos } \\
\text { (que não atenderam ao modelo e precisam mudar): }\end{array}$ \\
\hline $\begin{array}{l}\text { Há demanda para distribuição do } \\
\text { calçado escolar em todo território } \\
\text { Nacional, considerando, como } \\
\text { referência, o número de alunos } \\
\text { pertencentes as famílias } \\
\text { cadastradas no Programa Bolsa } \\
\text { Família. } \\
\text { O MEC concede rubrica aos } \\
\text { municípios para compra do } \\
\text { calçado escolar e disponibiliza o } \\
\text { FNDE para dar o suporte nos } \\
\text { processos de compra nacional. }\end{array}$ & $\begin{array}{l}\text { Há demanda para distribuição } \\
\text { do calçado escolar. } \\
\text { A prefeitura não distribui o } \\
\text { calçado escolar. } \\
\text { A cidade é reconhecida } \\
\text { mundialmente como o polo } \\
\text { calçadista mais importante por } \\
\text { ser um aglomerados de } \\
\text { empresas ou cluster (a cidade } \\
\text { do calçado). }\end{array}$ & $\begin{array}{l}\text { Há demanda para distribuição } \\
\text { do calçado escolar. } \\
\text { A Prefeitura distribui kits de } \\
\text { uniforme escolar, incluindo o } \\
\text { sapato. }\end{array}$ & $\begin{array}{l}\text { MEC concede rubrica para compra nacional e por licitação } \\
\text { municipal. } \\
\text { O modelo de compra por pregão nacional possui entraves. } \\
\text { O sistema-modelo propõe duas alternativas para implementação: } \\
\text { uma governamental e a outra por aglomerados de agentes da } \\
\text { sociedade civil (não dependente do governo). } \\
\text { Há demanda para o sistema do calçado em nível nacional. Os } \\
\text { dois municípios apresentaram demanda para distribuição do } \\
\text { calçado. } \\
\text { A prefeitura de DC prioriza as empresas locais para compra do } \\
\text { calçado. Na cidade há um APL do Calçado em formação. } \\
\text { Sobre o método projetual e a situação a ser atendida } \\
\text { Ao priorizar a investigação da situação, ao invés de realizar } \\
\text { análises diacrônicas ou sincrônicas como método projetual, são } \\
\text { reguardados, o caráter inovador da solução tecnológica a ser } \\
\text { alcançada e o atendimento aos requisitos obrigatórios e } \\
\text { desejados. }\end{array}$ & 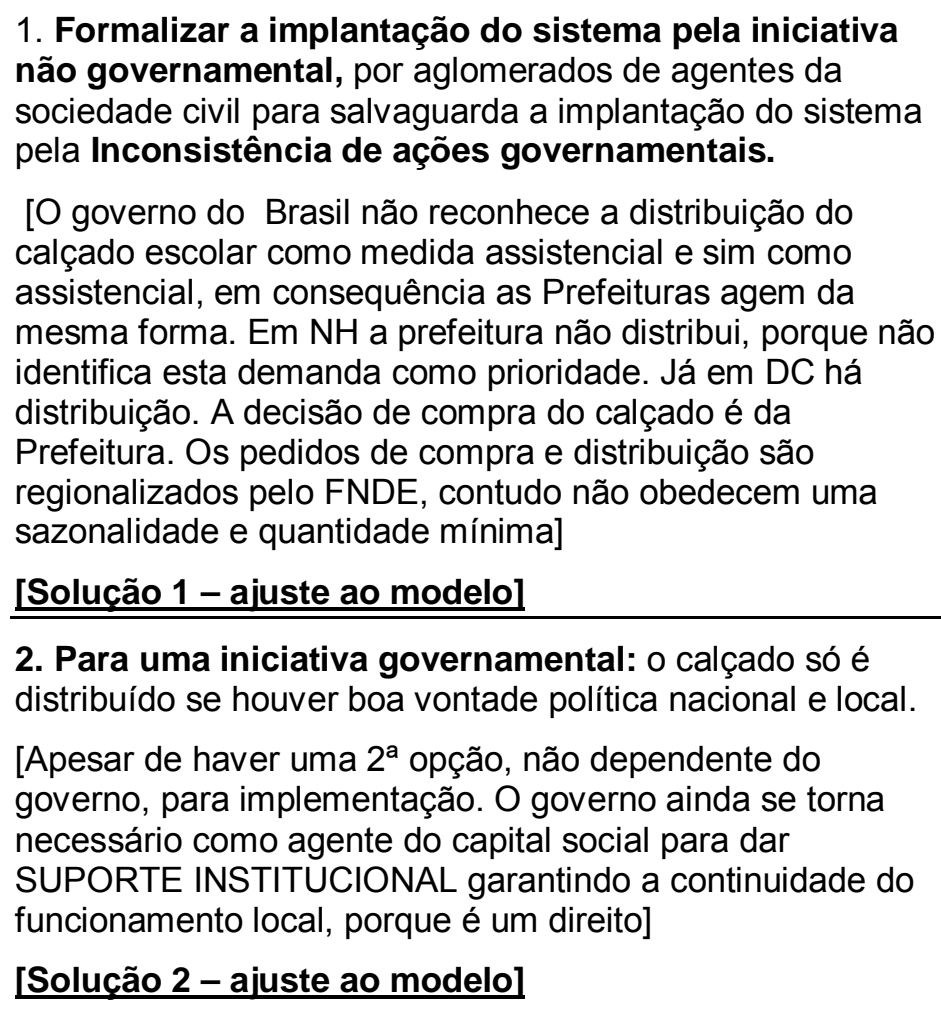 \\
\hline
\end{tabular}

\section{Ajustes no sistema modelo:}

[Solução 1 - ajuste ao modelo]

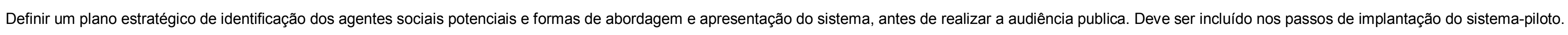
[Solução 2 - ajuste ao modelo]

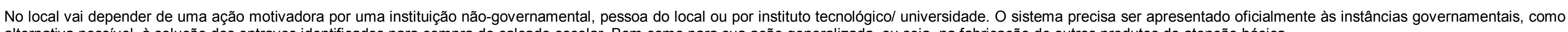
alternativa possível, à solução dos entraves identificados para compra do calçado escolar. Bem como para sua ação generalizada, ou seja, na fabricação de outros produtos de atenção básica.

Contribuição ao Campo do design social 1: Fortalecer o hábito de priorizar a investigação da situação, antes de identificar soluções similares já reconhecidas, para o desenvolvimento do método projetual.

Figura 63 - Análise final sobre a Fase 1a 
4.10.2.

Definição do problema (Fase 1)

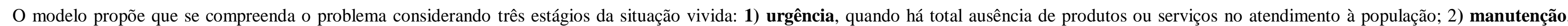

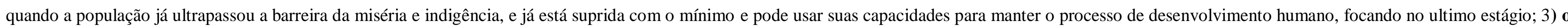

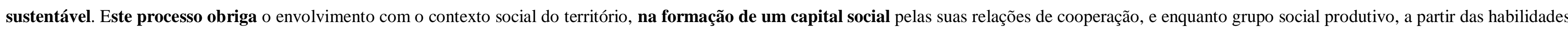
e especializações complementares. A meta é atender os três estágios mantendo um contínuo processo de desenvolvimento até que seja alcançado o estágio sustentável.

Definição do problema

\begin{tabular}{|c|c|c|c|}
\hline Problema nacional & Necessidades a serem atendidas pelo calçado escolar & Pontos fortes (que atenderam ao modelo) & $\begin{array}{l}\text { Pontos fracos (que não atenderam ao modelo e precisam } \\
\text { mudar) }\end{array}$ \\
\hline $\begin{array}{l}\text { demanda de calçado } \\
\text { scolar é de } 15,4 \text { milhões, } \\
\text { ara atender os alunos de } \\
\text { amílias beneficiárias do } \\
\text { rograma Bolsa Familia. } \\
\text { Ps preços dos tênis no } \\
\text { nercado significam } 42,14 \% \\
\text { tênis masculino) e } 67,60 \% \\
\text { tênis feminino) do valor } \\
\text { nédio de } R \$ 167,56 \text { (cento e } \\
\text { essenta e sete reais e } \\
\text { inquenta e seis centavos) } \\
\text { agoo pelo Beneficio a uma } \\
\text { amília (MDS, 2015). }\end{array}$ & $\begin{array}{l}\text { 1. O calçado escolar é de atenção básica para alunos de } \\
\text { escolas públicas do Brasil. } \\
\text { 2. Sua distribuição enquanto direito preserva a dignidade } \\
\text { humana dos alunos. } \\
\text { 3. Protege os pés durante a marcha; previne doenças de } \\
\text { solo (geominthoses) e doenças musculoesqueléticas } \\
\text { quando confortável. } \\
\text { 4. Permite segurança durante as atividades escolares; } \\
\text { 5. Protege contra as intempéries; } \\
\text { 6. Protege os pés em outros ambientes que não o escolar, } \\
\text { porque é um calçado para ser usado em outros ambientes } \\
\text { que não somente a escola. }\end{array}$ & $\begin{array}{l}\text { O SPPD do calçado atende ao problema porque prevê ação em } 3 \\
\text { estágios da situação: } \\
\text { 1.Assume-se a distribuição gratuita para a população em situação de } \\
\text { urgência; } \\
\text { 2.com a implantação do sistema no local, e pela ação dos grupos } \\
\text { sociais produtivos, assume-se que haverá geração de trabalho e renda } \\
\text { para o pessoal local e consequente desenvolvimento local. } \\
\text { 3. Em especial, espera-se que uma parcela desta população em } \\
\text { urgência migre para o estágio de manutenção, o que a possibilita } \\
\text { comprar, a preço justo, o seu calcado, movimentando a economia } \\
\text { local e garantindo a cidadania e auto-estima desta população em } \\
\text { direção ao } 3^{\circ} \text { estagio de uma vida sustentável. } \\
4.0 \text { método em design prevê a investigação da situação problema, o } \\
\text { que irá garantir o atendimento dos requisitos obrigatórios e desejados } \\
\text { do calçado. }\end{array}$ & $\begin{array}{l}\text { 1. O desafio de formar o capital social } \\
\text { [de constituir a formação do capital social e, } \\
\text { consequentemente, a formação do grupo social produtivo] } \\
\text { [Solução } 3 \text { - ajuste ao modelo] } \\
\text { 2. As duas lógicas econômicas } \\
\text { [definir um preço justo pelo conceito de comercio justo é um } \\
\text { desafio também, porque há duas lógicas econômicas em } \\
\text { questão: a de capital e a solidária (das relaçôes). Contudo não } \\
\text { precisam ser excludentes, desde que na chamada publica para } \\
\text { formação do capital social seja informado a FONTE DE } \\
\text { FOMENTO para o sistema e o ciclo econômico do SPPD] } \\
\text { [Solução 4 - ajuste ao modelo] }\end{array}$ \\
\hline
\end{tabular}

\section{Ajustes ao modelo:}

[Solução 3 - ajuste ao modelo]: O modelo deve prever a ação estratégica do design para identificar os potenciais agentes sociais e configurar uma abordagem anterior a chamada pública.

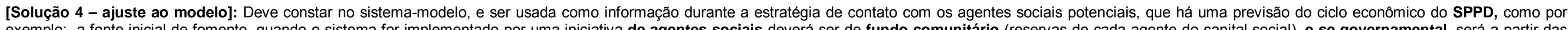

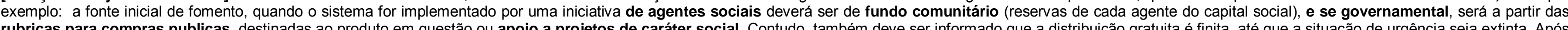

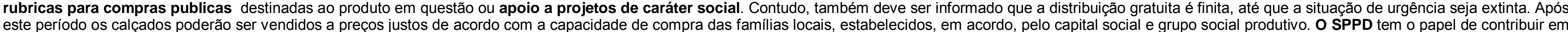
motivar as pessoas ao desenvolvimento de suas capacidades e a meta de uma vida sustentável.

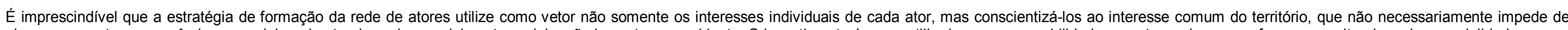
alcançar um retorno econômico, sem deixar de atender o desenvolvimento social e não impactar no ambiente. O investimento é compartilhado, as responsabilidade e o retorno da mesma forma, respeitando cada especialidade.

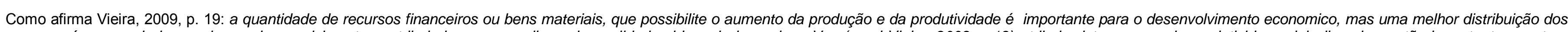

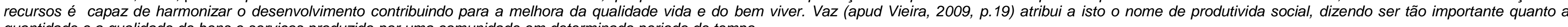

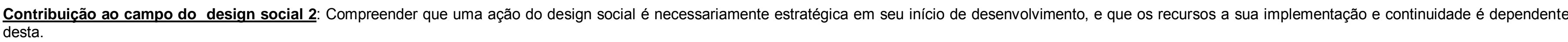

Figura 64 - Análise final sobre a Fase 1b 
4.10.3.

Características estratégicas do sistema de projetação, produção e distribuição do calçado escolar (Fase 1)

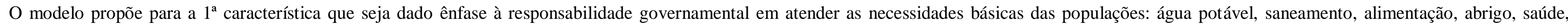

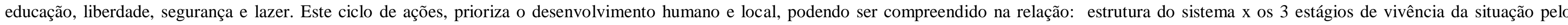
público-alvo x o formato sob a lógica da THDS (Figura 6, Capitulo II).

\begin{tabular}{|c|c|c|}
\hline \multicolumn{3}{|c|}{ 1. Característica estratégica } \\
\hline A realidade do estudo de caso & Pontos fortes (que atenderam ao modelo) & Pontos fracos (que não atenderam ao modelo e precisam mudar) \\
\hline $\begin{array}{l}\text { O Governo Brasileiro, através do MEC/FNDE, é o } \\
\text { responsável pela compra dos calçados escolares. } \\
\text { Uma ação que se apresenta no formato (governo- } \\
\text { empresa) e que não reproduz qualquer formato de rede de } \\
\text { atores para o desenvolvimento de inovação tecnológica, } \\
\text { apresentado pela literatura estudada } \\
\text { Com os resultados do trabalho de campo, identificou-se } \\
\text { que o direito em receber o calçado escolar não é } \\
\text { garantido, porque as prefeituras tem gerencia na decisão } \\
\text { de concede-lo à população ou não. }\end{array}$ & $\begin{array}{l}\text { O calçado escolar demonstrou ser um bom exemplo para experimentar o sistema- } \\
\text { modelo porque: } \\
\text { é um produto de atenção básica, portanto os alunos pertencentes a famílias em estado de } \\
\text { carência tem o direito recebê-lo, gratuitamente. } \\
\text { sua demanda é nacional e pode ser territorializada, porque é pulverizada a distribuição } \\
\text { geográfica da indústria calçadista brasileira, enquanto APL ou não, e há disponibilidade de } \\
\text { artesãos utilitários - sapateiros. } \\
\text { Sob a perspectiva do design: } \\
\text { (projeto de produto) é um produto de complexidade tecnológica e o FNDE não possui } \\
\text { designers no quadro de funcionários. } \\
\text { (design estratégico) é um produto que requer estratégias para congregar os recursos } \\
\text { necessários ao seu sistema de projetação e produção, em especial para a formatação da } \\
\text { rede de atores para o desenvolvimento das inovações tecnológicas de caráter social que se } \\
\text { fizerem necessárias. }\end{array}$ & $\begin{array}{l}\text { O direito existe, mas não é garantido } \\
\text { [O caráter inovador da proposta do SPPD atrelado ao não } \\
\text { reconhecimento do direito do individuo, contudo há rubrica pelo governo } \\
\text { para compra e a há uma segunda alternativa do para implementação do } \\
\text { sistema]. } \\
\text { [Solucão } 5 \text { - ajuste ao modelo] } \\
\text { O FNDE por não possui designers no seu quadro } \\
\text { [Se houver implementação governamental, haverá ausência na estratégia } \\
\text { de implementação do sistema] } \\
\text { [Solução } 6 \text { - ajuste ao modelo] }\end{array}$ \\
\hline $\begin{array}{l}\text { Ajustes no sistema modelo: } \\
\text { [Solução } 5 \text { - ajuste ao modelo]: A estratégia de aboro } \\
\text { desenvolvimento econômico, social e ambiental em ca }\end{array}$ & 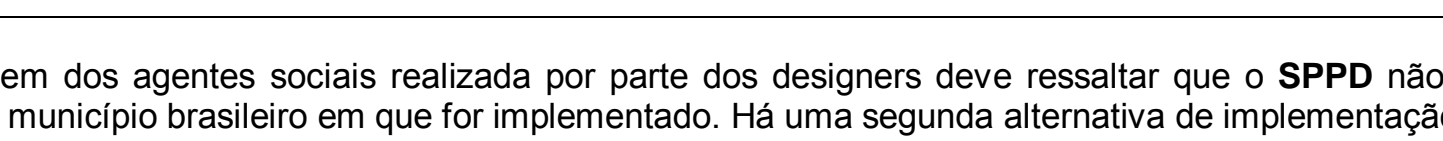 & $\begin{array}{l}\text { reve a manutenção do assistencialismo, pois foca em contribuir com o } \\
\text { lo sistema pelo grupo de agentes sociais locais. }\end{array}$ \\
\hline
\end{tabular}

Figura 65 - Analise final sobre a Fase 1c: $1^{\text {a }}$. Característica.

\footnotetext{
${ }^{34}$ (Sábato e Botana (1975), Etzkowitz e Leydesdorff (1998); Etkowitz e Zhou, 2006; Senhoras (2008, p. 139); Carvalho (2009, p. 111); BRASIL (2010, p. 18).
} 


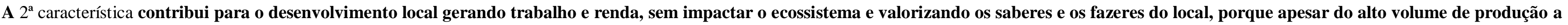
demanda é melhor atendida se for territorializada, porque cada região apresenta suas subjetividades e suas oportunidades.

A formação de uma cadeia de suprimentos do mercado tradicional local ou somente os conhecimentos tácitos e as habilidades de ofícios dos artesãos locais, não permitiriam satisfazer as especificações técnicas de produtos e processos.

A formação de um capital social produtivo que represente o potencial do local (industrial e artesanal) é capaz de satisfazer as exigências técnicas e as necessidades dos indivíduos.

\begin{tabular}{|c|c|c|}
\hline \multicolumn{3}{|c|}{ 2. Característica estratégica } \\
\hline A realidade do estudo de caso & Pontos fortes (que atenderam ao modelo) & Pontos fracos (que não atenderam ao modelo e precisam mudar) \\
\hline $\begin{array}{l}\text { O sistema para o calçado escolar assume a presença de um capital } \\
\text { social local capaz de satisfazer as exigências técnicas de } \\
\text { produtos e processos. } \\
\text { O mesmo define uma Unidade Executora (UEx), a mesma } \\
\text { alternativa usada pelo Programa Nacional de Alimentação Escolar } \\
\text { (PNAE) para: } \\
\text { • dispensar o processo licitatório e permitir compra direta de } \\
\text { alimentos dos agricultores locais. } \\
\text { - dispensar a figura do atravessador e assegurar um preço } \\
\text { justo e movimentar a economia local; } \\
\text { - contribuir com o desenvolvimento local escoando a } \\
\text { produção, gerando trabalho e renda local. }\end{array}$ & $\begin{array}{l}\text { Um Capital social conforme proposto pelo modelo, designando parte do } \\
\text { papel controlador a uma UEx: } \\
\text { 1. exclui os entraves, conforme vem ocorrendo na compra do calçado } \\
\text { por pregão e licitação nacional (larga escala) } \\
\text { 1. controla os requisitos de produto e processos no local (requisitos } \\
\text { obrigatórios); } \\
\text { 2. garante os atributos do produto citados pelos alunos (requisitos } \\
\text { desejados). } \\
\text { 3. contribui com o desenvolvimento local, gerando trabalho e renda na } \\
\text { valorização do ecossistema e dos saberes e fazeres do local, tanto } \\
\text { artesanal como tecno-industrial. }\end{array}$ & $\begin{array}{l}\text { Identificar os agentes sociais com capacidade para participar do capital social. } \\
\text { [Solução } 7 \text { - ajuste ao modelo] } \\
\text { Manter um formato de rede de atores do tipo HTD } \\
\text { govertentabilidade (universidade-empresa- } \\
\text { tecnológico socialade), estrategicamente motivado a alavancar o desenvolvimento } \\
\text { [Solução } 8 \text { - ajuste ao modelo] }\end{array}$ \\
\hline
\end{tabular}

\section{Ajustes no sistema modelo:}

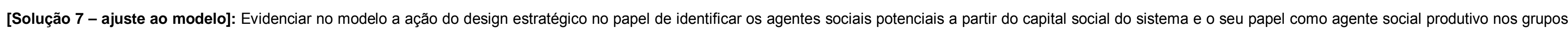
que se formarem nos territórios.

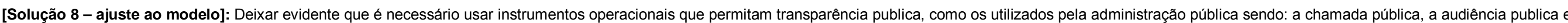

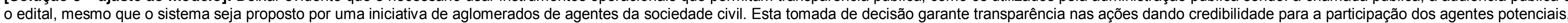
bem como de instancias governamentais.

Contribuição ao Campo do design social 4: Desenvolver métodos e ferramentas que contribuam com a inovação tecnológica social pela lógica THDS

Figura 66 - Análise final sobre a Fase 1c: 2a . Característica. 


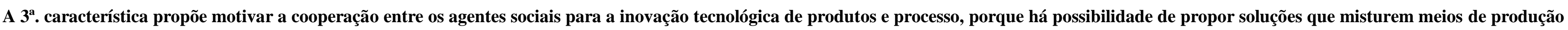
industrial (local ou mais próximo possível geograficamente) com as habilidades dos artesãos (artesanato utilitário) para impulsionar o desenvolvimento local.

A fundamentação vincula-se: 1) ao grau de padronização dos produtos; 2) satisfazer as necessidades; e 3) exigências em complexidade de produtos e processos de cada território

A inovação tecnológica DEVE SE DAR em cooperação com o grupo social produtivo local ou de lugares o mais próximo possível, atendendo 2 estratégias:

1) adotar formato Tríplice Hélice Dupla para a sustentabilidade (empresa-universidade-governo-sociedade)

2) aplicar a prática do sistema de produção distribuída (SPD), definido como a descentralização da produção, por meio de uma rede de fábricas geograficamente dispersas, mas que podem ser coordenadas por meio de tecnologia da informação (Kühnle, 2010; Whang e Shen, 2007).

3a. Característica estratégica

\begin{tabular}{|c|c|c|}
\hline \multicolumn{3}{|c|}{ 3. Característica estratégica } \\
\hline Com a realidade do estudo de caso & Pontos fortes (que atenderam ao modelo): & Pontos fracos (que não atenderam ao modelo e precisam mudar): \\
\hline $\begin{array}{l}\text { O sistema do calçado define os recursos e desenvolvimento de } \\
\text { inovação tecnológica cooperativo para seu planejamento } \\
\text { operacional por meio do: } \\
\text { formato de organização da indústria calçadista no brasileira, } \\
\text { que é de Polos Produtivos, reconhecidos por clusters ou } \\
\text { arranjos produtivos locais. } \\
\text { tradicional processo produtivo da indústria calçadista brasileira, } \\
\text { do tipo semi-industrial, intensivo em mão de obra e exigente em } \\
\text { desenvolvimento tecnológico e inovação. } \\
\text { mix entre meios de produção industrial (máquinas e } \\
\text { equipamentos), artesanal (manual) e tecnológico (softwares } \\
\text { específicos). }\end{array}$ & $\begin{array}{l}\text { as inter-relaç̃̃es que ocorrem entre as empresas } \\
\text { pertencentes aos aglomerados ou em trabalho compartilhado } \\
\text { à distância com outros. } \\
\text { o tradicional processo produtivo da indústria calçadista } \\
\text { brasileira permite fortalecer a } 2^{\mathrm{a}} \text {. e } 3^{\mathrm{a}} \text {. características } \\
\text { estratégicas do sistema. } \\
\text { Os meios de produção já utilizados pela indústria do } \\
\text { calçado fortalece a proposta de produção distribuída } \\
\text { como estratégia de desenvolvimento da inovação } \\
\text { tecnológica social necessária para a implementação do } \\
\text { sistema com capacidade de gerar seus recursos de } \\
\text { produção. }\end{array}$ & $\begin{array}{l}\text { Operacionalização da estrutura de desenvolvimento tecnológico social pela lógica da } \\
\text { THDS. } \\
\text { [Solução } 9 \text { - ajuste ao modelo]: } \\
\text { O sistema-modelo quando aplicado a outros setores produtivos, que não possuem a } \\
\text { pratica do uso da do sistema de produção distribuída (SPD) como a industria calçadista } \\
\text { cabe adequar-se. } \\
\text { [Solução } 10 \text { - ajuste ao modelo]: }\end{array}$ \\
\hline
\end{tabular}

\section{Aiustes no sistema modelo:}

[Solução 9 - ajuste ao modelo]: não foram identificadas experiências projetuais do design social utilizando esta lógica à inovação tecnológica social, desta forma, cabe instruir o sistema-modelo de que é preciso um tempo experimental para que se legitime, como uma alternativa "ótima", visto que nem o Sistema Nacional de Inovação do Brasil prevê este formato.

[Solução 10 - ajuste ao modelo]: O modelo deve ressaltar que não havendo uma prática de uso do sistema de produção distribuída (SPD) do setor produtivo em questão, deverão ser previstos planejamentos para informação e adequação.

Contribuicão ao Campo do design social 5: Desenvolver habilidades para atuação entre o método de design e a aplicação prática do sistema de produção distribuída (SPD) em prol do desenvolvimento da inovação tecnológica social sob o lógica THDS.

Figura 67 - Análise final sobre a Fase 1c: 3ª Característica. 
4.10.4.

\section{Demanda e local do sistema (Fase 1)}

O modelo propõe que o sistema atenda populações carentes de produtos de necessidade básica. Em se tratando da realidade brasileira, a demanda é de larga escala, pois compreende, no mínimo, 39.150 .981

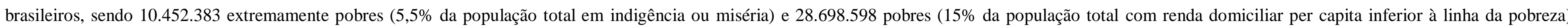

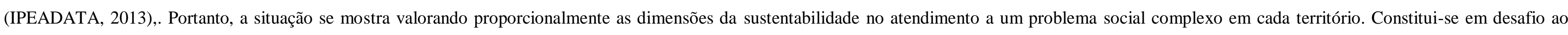
campo do design, porque diante os três estágios de atenção a uma necessidade básica (figura 15) nem sempre será suficiente o re-design ou um desenho incremental.

\begin{tabular}{|c|c|c|c|c|}
\hline \multicolumn{5}{|l|}{ Demanda do sistema } \\
\hline $\begin{array}{l}\text { Sistema Nacional do } \\
\text { Calçado }\end{array}$ & Grupo de NH & Grupo de DC & Pontos fortes (que atenderam ao modelo): & $\begin{array}{l}\text { Pontos fracos (que não atenderam ao } \\
\text { modelo e precisam mudar) }\end{array}$ \\
\hline $\begin{array}{l}\text { O número de alunos } \\
\text { matriculados no ensino } \\
\text { fundamental das redes de } \\
\text { ensino público de todo o } \\
\text { Brasil (demanda nacional)l } \\
\text { foi de } 28.459 .667 \text { em } 2014 . \\
\text { Já no primeiro semestre de } \\
2015 \text { foram de } 21.431 .522 \\
\text { matrículas nas redes }\end{array}$ & $\begin{array}{l}\text { O número de alunos matriculados no } \\
\text { ensino fundamental da rede pública, } \\
\text { estadual e municipal é de } 23.426 \text { alunos. } \\
\text { Não há distribuição do calçado escolar } \\
\text { apesar: } \\
\text { 1. do IDHM de Novo Hamburgo ser de } \\
\text { 0,747 (Atlas Brasil 2010). } \\
\text { 2. do percentual de crianças vulneráveis } \\
\text { à pobreza ser de } 27,73 \% \text {, o de crianças } \\
\text { pobres ser de } 8,70 \% \\
\text { 3. do percentual de mães, chefes de } \\
\text { família, sem fundamental e com filho } \\
\text { menor, ser de } 48,45 \% \text {. } \\
\text { 4. De } 9.499 \text { famílias serem beneficiárias } \\
\text { do Programa Bolsa Família, o que } \\
\text { representa um percentual de } 19,90 \% \text { da } \\
\text { população, assumindo que a média } \\
\text { familiar seja de } 5 \text { componentes, } \\
\text { considerando que a população de Novo } \\
\text { Hamburgo é de } 238.940 \text { (IBGE 2010). }\end{array}$ & $\begin{array}{l}\text { Os municípios de Duque de Caxias e } \\
\text { Belford Roxo tiveram, } \\
\text { respectivamente, } 72.424 \text { e } 21.503 \\
\text { alunos matriculados no ensino } \\
\text { fundamental, representando } 7,75 \% \text { do } \\
\text { total de alunos do estado do Rio de } \\
\text { Janeiro. } \\
\text { Ambos os municípios distribuem } \\
\text { calçados escolares }\end{array}$ & $\begin{array}{l}\text { Nacional } \\
\text { Ao analisar a demanda geral, sob a perspectiva do índice de } \\
\text { desenvolvimento humano municipal (IDHM), foi identificado um } \\
\text { grupo de brasileiros em situação de urgência para atendimento, } \\
\text { definindo territórios, em prioridade, para implantação do } \\
\text { sistema. } \\
\text { Levar em consideração os estados e seus municípios com } \\
\text { maiores índices de pobreza e miséria. } \\
\text { Se o modelo de plano-mestre de produção deste sistema fosse } \\
\text { utilizado para abrangência nacional, a estratégia de ação seria } \\
\text { de curto prazo, focada ao estágio de urgência. } \\
\text { NH } \\
\text { NH é uma cidade polo calçadista com capacidade de atender as } \\
\text { necessidades de recursos do sistema, inclusive o } \\
\text { desenvolvimento de inovação tecnológica. } \\
\text { DC } \\
\text { A prefeitura de DC já distribui e prioriza comprar os calçados } \\
\text { escolares de empresas locais. } \\
\text { Há uma APL do Calcado em formação } \\
\text { Há um centro tecnológico em construção com data para iniciar } \\
\text { suas atividades em março de } 2016 \text {. }\end{array}$ & $\begin{array}{l}\text { Nacional } \\
\text { Se fosse possível uma relação direta entre a } \\
\text { necessidade de mão de obra para a produção } \\
\text { de calçados, por estados prioritários em } \\
\text { atendimento, com o número de pessoas } \\
\text { vivendo em domicílios vulneráveis, o sistema } \\
\text { já estaria contribuindo com a geração de } \\
\text { trabalho e renda, e desenvolvimento humano } \\
\text { em todos os territórios. }\end{array}$ \\
\hline
\end{tabular}

Figura 68 - Análise final sobre a Fase 1d: sobre a demanda 
Sobre o Local

O modelo propõe que o local seja todo território brasileiro, contudo que seja de atenção customizada a cada município. Em especial aqueles que possuem baixo IDHMunicipal.

\begin{tabular}{|c|c|c|}
\hline \multicolumn{3}{|l|}{ Local do sistema } \\
\hline Os locais do SPPD & Pontos fortes (que atenderam ao modelo): & Pontos fracos (que não atenderam ao modelo e precisam mudar): \\
\hline $\begin{array}{l}\text { E territorial porque para funcionar e operar depende das } \\
\text { mínimas e básicas características de cada território, que são } \\
\text { diversas e mudam de região para regiâo. }\end{array}$ & $\begin{array}{l}\text { Considerar o IDHMunicipal permite identificar localidades em } \\
\text { prioridade no Brasil; } \\
\text { O sistema de produção distribuída permite trabalhar em parceria com } \\
\text { instituiç̃̃es tecnológicas ou APL's geograficamente localizados em } \\
\text { outra região para atender a demanda do território. } \\
\text { A capacidade de produção com a disponibilidade de mão de obra à } \\
\text { demanda do território, mais a presença de instituições tecnológicas } \\
\text { para apoiar as inovações e a oferta de matéria-prima local, ou o mais } \\
\text { próximo do território. }\end{array}$ & $\begin{array}{l}\text { O local também é virtual } \\
\text { [O Sistema de produção distribuída permite ao sistema interrelacionar com outros } \\
\text { agentes sociais produtivos à distancia. Contudo há que se formar a infraestrutura e as } \\
\text { relacoes para que funcione a contento.] } \\
\text { [Solução } 13 \text { - ajuste ao modelo] }\end{array}$ \\
\hline \multicolumn{3}{|l|}{ Ajustes no sistema modelo: } \\
\hline \multicolumn{3}{|c|}{$\begin{array}{l}\text { [Solução } 13 \text { - ajuste ao modelo]: Deve ser incluído no sistema modelo que além do local do SPPD considerar todos o território do Brasil, bem como cada município, há que considerar que o local também é virtual. C } \\
\text { Desenvolvimento tecnológico previsto contempla grupos de agentes produtivos à distância. }\end{array}$} \\
\hline
\end{tabular}

Figura 69 - Análise final sobre a Fase 1d: sobre o local 
4.10.5.

Planejamento da implementação e gestão do sistema produtivo (Fase 2)

Para que o sistema produtivo transforme suas entradas em produtos, o modelo propõe a adoção de planos e ações a curto, médio e longo prazo, construindo uma relação entre os 3 estágios de desenvolvimento humano (urgência, manutenção e sustentabilidade) para atender sua demanda e os prazos para ação do Planejamento produtivo.

Em curto prazo, será uma medida de urgência para amenizar o sofrimento dessas pessoas que estão em situação de carência em seu dia a dia

Em paralelo, a implementação do sistema deverá seguir com atividades de médio e longo prazo, porque visam a manutenção ou desenvolvimento humano contínuo, com ação em cada território, gerando trabalho e renda, para que essas pessoas não retornem ao estágio de urgência inicial.

São previstas complexidades na relação entre o grau de padronização dos produtos, a diversidade de contextos sociais, ambientais e culturais do Brasil e o volume de produção que tendem a se intensificar nas ações de médio e longo prazo.

O modelo esclarece que o Governo ou o grupo de agentes sociais, não são fabricantes do produto, e sim um cliente, que ao mesmo tempo exerce o papel de gestor do processo de produção pelo poder de compra e controle que possui.

\begin{tabular}{|c|c|c|}
\hline Planejamento Nacional & Pontos fortes (que atenderam ao modelo) & Pontos fracos (que não atenderam ao modelo e precisam mudar) \\
\hline $\begin{array}{l}\text { O funcionamento do sistema de produção do calçado } \\
\text { escolar tem o planejamento de seu cronograma em } \\
\text { função do calendário escolar das escolas, por semestre } \\
\text { letivo, de cada município. }\end{array}$ & $\begin{array}{l}\text { O período de matrícula é sempre realizado } 1 \text { mês antes de iniciar as férias de final de ano, por } \\
\text { isso marca o início do planejamento da produção para o sistema do calçado escolar e a chance } \\
\text { de coleta de dados: antropométricos, de fatores do simbólicos e estéticos permitirão identificar } \\
\text { requisitos desejados ao Método de design; Uma estimativa de valor do produto e outras } \\
\text { informacões relevantes para auxiliar na proietacão. }\end{array}$ & As escolas não aceitarem coletar mais dados no período de matrícula. \\
\hline
\end{tabular}

\section{Ajustes no sistema modelo:}

[Solução 14 - ajuste ao modelo]: O modelo deve considerar a necessidade de que outros Ministérios e Secretarias façam parte do capital social do Sistema, para contornar o ponto fraco.. .Por exemplo: o MDS e a Secretaria de desenvolvimento social; o MDIC, O MCT, e Min Trab. e as Secretaria de desenvolvimento Econômico.

Contribuição ao Campo do design social 8:. Um banco de dados multifunção composto por dados antropometricos, fatores simbólicos e estéticos de uma determinada população, região e época, com capacidade de cruzar os dados com os dados socioeconômicos alimentados pelas matriculas dos alunos da rede de ensino publica do Brasil.

Figura 70 - Análise final da FASE 2 
4.10.6.

\section{Formação do capital social (Fase 3)}

Para atender as estratégias do sistema, faz-se necessário iniciar o Plano Mestre da Produção (PMP) pela definição do capital social, do grupo social produtivo e de desenvolvimento da inovação, com

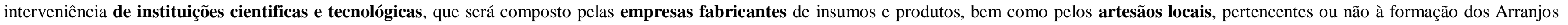
Produtivos Locais (APL's). Contudo, a Empresa focal ou gestora do sistema no local deverá estimar, listar e convidar agentes sociais de relevância diante as estratégias de operacionalização do sistema.

\section{Capital social naciona}

Detém uma iniciativa governamental, no formato de rede de atores do tipo THDS, composta pelo governo, as empresas, a

1. Dando ao Governo o papel de Empresa focal, 2. Já a Unidade Executora local (Uex) deverá ser escolhida pelo Capital social de cada território.

3. Os APL's tem o papel, diante sua formação, de facilitar o acesso às universidades, às empresas e aos artesãos. 4. Já a comunidade estará se apresentando pela articulação

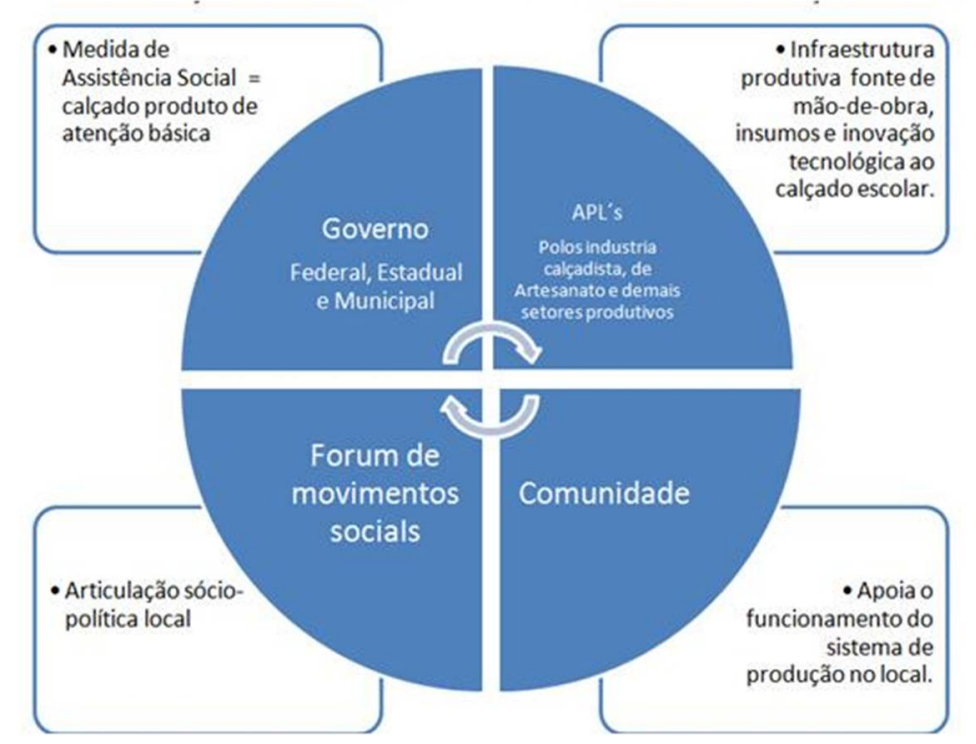

Detém uma iniciativa por aglomerados de agentes sociais, no formato de rede de atores do tipo THDS, composta pelo governo, as empresas, a universidade e a com iniciati 6. No caso de NH, não há empresa focal e sim Unidade Executora que representa o aglomerado de agentes sociais: a Incubadora da Prefeitura, nas pessoas dos Gestores Neca e Alex. participa como apoiador administrativo para a ação da Incubadora, entendida como experimental. Futuramente, já esta se discutindo a presença da prefeitura como agente de fomento e apoio político para as ações do projeto, especialmente junto as empresas fabricantes de insumos, através de suas Entidade de Classe.

A participação do Governo, como Empresa focal, tomando iniciativa à implantação do sistema em parceria com demais Secretarias, como a de educação, não foi possível, pela dificuldade em apresentar o projeto a Secretaria de Educação Municipal. Por este motivo foi construído, estrategicamente, um atalho pela Incubadora Popular para o experimento.

8. As empresas fornecedoras de insumos são representadas pela ASSINTECAL;

9. As empresas fabricantes são as MPE's ou fabriquetas de bairro; 10. A comunidade é representada pelas habildades locais das artesãs da como de Economia Solidária e pelo Sindicato dos trabalhadores das Industrias de Calçados.

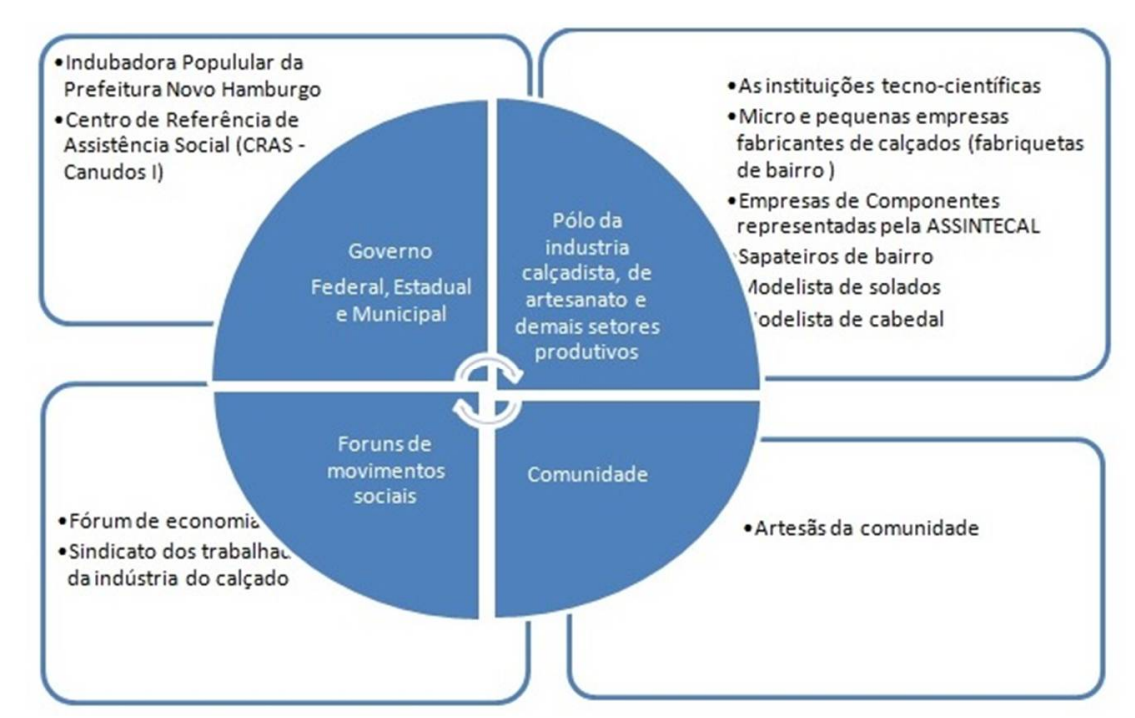

\section{Capital social de DC}

Detém uma iniciativa por aglomerados de agentes sociais, no formato de rede de atores do tipo Tríplice Hélice, composta pelo governo, as

cimento tecno-

Esta condição de $D C$ deve-se ao fato de que o Município está em comunidade, cooperados ou não, que fabricavam os calçados, sem qualquer infraestrutura de apoio á producão. 1. Em DC não se chegou a definir uma Unidade Executora, mas o $\mathrm{Sr}$. Avelino, presidente da COOPFERJ, tornou-se a pessoa representante do grupo.

2. O Governo, representado pela SEDEC da Prefeitura de DC e a SEDES do Estado do RJ que participaram como apoiadores administrativos e informantes sobre as caracteristicas do Municipio demonstraram interesse em experimentar oficialmente o SPPD após a implementação do APL do Calçado.

3. As empresas ficaram representadas pela Cooperativa de Fabricantes de Calçados de Duque de Caxias (COOPFERJ) e por sua cadeia de

4. A comunidade ficou representada pelo modelista que estava trabalhando com o Sr. Avelino na montagem do protótipo. Não houve

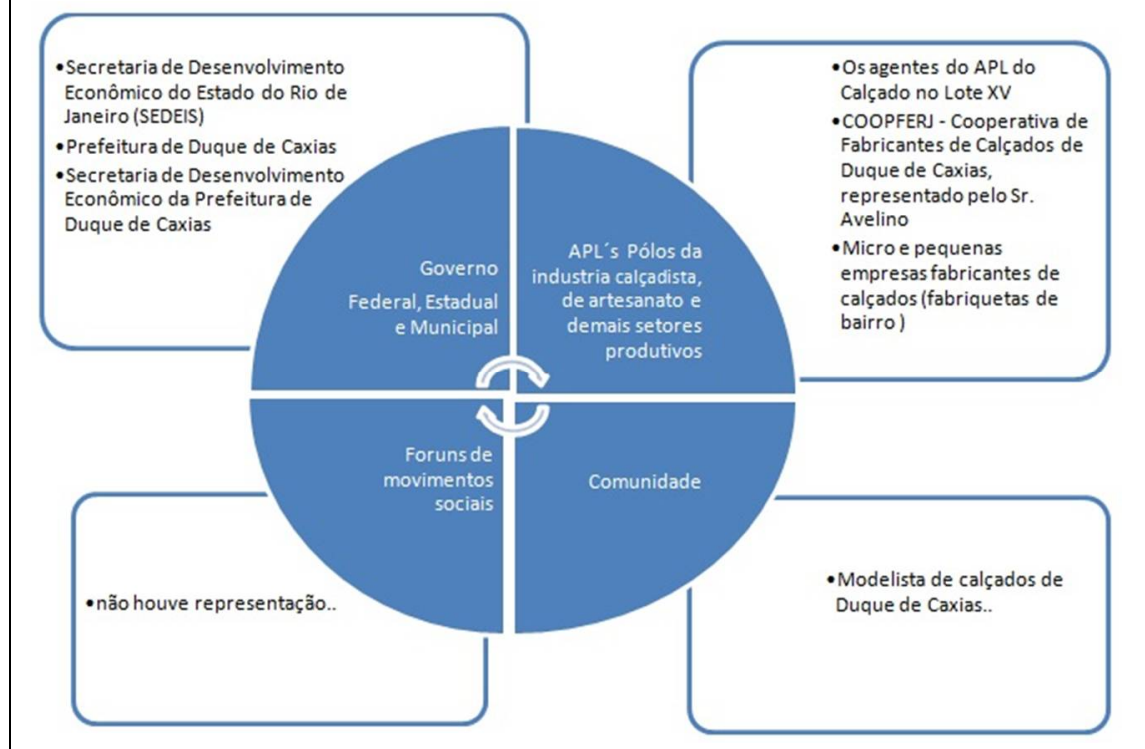




\section{Pontos fortes (que atenderam ao modelo)}

1. O formato de rede de atores do sistema do calçado nacional e de $\mathrm{NH}$ configurou-se como do tipo THDS, e demonstrou que contribui com o desenvolvimento da inovação tecnológica socia tanto para uma iniciativa governamental, quanto para uma iniciativa por aglomerados de agentes sociais, quando todos os seus atores estão envolvidos.

2. A presença das incubadoras tecnológicas ou populares, vinculadas às Prefeituras ou as Universidades mostraram ser motivadoras da implementação do Sistema pela iniciativa de aglomerados de agentes sociais. Como tambem podem fazer o papel de Unidades Executoras no ocal.

Os fóruns de movimentos sociais na cidade demonstraram ser motivadores à implementação do sistema quando realizada por aglomerados de agentes sociais.

\section{Ajustes no sistema modelo:}

[Solução 15 - ajuste ao modelo]: O modelo deve prever a ação estratégica do design, enquanto agente social do capital social, representando uma instituição de desenvolvimento tecnológico, como também agente do grupo social produtivo, para apoiar no estabelecimento das relações que já existem entre os agentes locais, mas que precisam mediação para harmonizar as tensões que ocorrem em função dos interesses individuais em relação aos interesses em comum ao território.

[Solução 16 - ajuste ao modelo]: Inserir no modelo que é importante a presença das incubadoras populares ou tecnológicas e os movimentos sociais locais como participantes do capital social do SPPD.

Contribuição ao Campo do design social 9: A ação coordenada entre as diferentes instituições para criar e motivar o surgimento das dinâmicas de inovações sociais e econômicas, permitindo a oportunidade do designer transitar e congregar, de forma estratégica e produtiva, contextos organizacionais de princípios conceituais diversos como: governamental, empresarial de micro, pequeno e médio porte; movimentos sociais e de grupos produtivos artesanais de cánter ulitário.

Figura 71 - Análise final Fase 3a
O situação ideal é de que todos os agentes listados participem. Contudo, são previstas tensões entre as relações, alguns (figura 7 , Capitulo II), o que vai impactar n: A ausência de boa

\section{[Solução 15 - ajuste ao modelo]}

\section{A importância das Incubadoras Populares e dos Foruns de movimentos sociais}

Ua foruns de movimentos sociais e de incubadoras populares ou tecnológicas no município pode dificultar a formação de um capital social para implementação do SPPD quando houve inação do Governo.

[Solução 16 - ajuste ao modelo]

\section{Previsão de tensões e omissões nas relações THDS}


4.10.7.

Oferta de mão de obra e insumos para o sistema de produção do calçado escolar (Fase 3)

Os APL's do Brasil podem ser a principal fonte para definir a mão de obra do sistema. São organizados por setores produtivos, e cada setor com seus segmentos, assim são interessantes para a formação de grupos sociais produtivos em oferta de mão de obra ou serviço: os APLs industriais; os APL's de artesanato e os APL's da economia criativa. Outra opção de mão de obra são os artesãos do utilitário que ainda não foram cadastrados no banco de APL's do artesanato (ou que queiram se manter sem cadastro). Considerar o artesão do utilitário, como fonte de mão de obra, pois é uma forma de reincorporar estes profissionais de valor cultural e simbólico ao território no modo de produção contemporâneo; incentivar um comportamento de consumo consciente na comunidade, a partir de seu trabalho de manutenção do produto durante o uso, que prolonga o ciclo de vida do produto e evita na fabricação de novos a geração de resíduos e uso de recursos ambientais. Quanto à questão de gênero, a presença das mulheres é constante, em números representativos, como formadoras de capital social.

Uma visão nacional para a disponibilidade de mão de obra

\begin{tabular}{|c|c|c|c|c|}
\hline \multicolumn{5}{|c|}{ Uma visão nacional para a disponibilidade de mão de obra } \\
\hline Sistema Nacional do Calçado & Grupo de NH & Grupo de DC & Pontos fortes (que atenderam ao modelo) & $\begin{array}{l}\text { Pontos fracos (que não atenderam ao } \\
\text { modelo e precisam mudar) }\end{array}$ \\
\hline $\begin{array}{l}\text { Mão de obra } \\
\text { Mapear os territórios pela localização dos Polos da } \\
\text { Indústria Calçadista brasileira e os Arranjos } \\
\text { Produtivos Locais do Calçado considerando: } \\
\text { - A localização no território nacional dos Polos } \\
\text { Calçadistas do Brasil } \\
\text { - O número de empresas fabricantes de calçados } \\
\text { O número de empresas fabricantes de calçados por } \\
\text { região do Brasil. } \\
\text { - Total de Profissionais no Brasil - Trabalhadores } \\
\text { artesanais da confecção de calçados e artefatos de } \\
\text { couros e peles/Moda } \\
\text { - Total de Profissionais para o Município Novo } \\
\text { Hamburgo - Trabalhadores artesanais da confecção } \\
\text { de calçados e artefatos de couros e peles/Moda } \\
\text { Total de Profissionais para o Município Duque de } \\
\text { Caxias - Trabalhadores artesanais da confecção de } \\
\text { calçados e artefatos de couros e peles/Moda } \\
\text { Há possibilidades de outros APL's, formados } \\
\text { historicamente pela interação natural entre os } \\
\text { agentes sociais do território } \\
\text { Insumos } \\
\text { O solado é um componente que demanda } \\
\text { desenvolvimento e inovação tecnológica para } \\
\text { atender os requisitos obrigatórios do método em } \\
\text { designn. }\end{array}$ & $\begin{array}{l}\text { Mão de obra } \\
\text { 1. A formação do capital social de } \\
\text { Novo Hamburgo disponibiliza como } \\
\text { mão de obra local os artesãos } \\
\text { manuais que participam das oficinas } \\
\text { da Incubadora Popular da Prefeitura e } \\
\text { as Fabriquetas de bairro ou MPME's } \\
\text { localizadas no município. } \\
\text { Insumos } \\
\text { 1. A cidade de NH faz parte do grupo } \\
\text { de municípios do Polo calçadista do } \\
\text { Vale do Rio dos Sinos e formada por } \\
\text { um cluster de empresas de atividade } \\
\text { relacionada. Há empresas de } \\
\text { componentes para calçados e } \\
\text { desenvolvimento de inovações } \\
\text { tecnológicas em quantidade } \\
\text { suficiente para atender, com novos } \\
\text { componentes ou com seus resíduos. } \\
\text { 2. O solado é o componente que } \\
\text { mais demandou comentário entre o } \\
\text { grupo social produtivo } \\
\text { Segundo informações de um sapateiro } \\
\text { local, um tênis pode ser manufaturado, } \\
\text { de forma multifuncional (célula de } \\
\text { produção) sem divisão do trabalho, por } \\
\text { uma pessoa, em } 30 \text { minutos }\end{array}$ & $\begin{array}{l}\text { A oferta de mão de obra para o } \\
\text { fornecimento do calçado no município } \\
\text { do Rio de Janeiro pode ter fonte nas } \\
\text { duas indicações de APL do Calçado } \\
\text { do Rio de Janeiro (OBAPL, 2015), que } \\
\text { estão localizados nos municípios de } \\
\text { Belford Roxo e Duque de Caixas, no } \\
\text { bairro do Lote XV e nas indicações do } \\
\text { Mural de Economia Criativa sobre os } \\
\text { trabalhadores artesãos da Confecção } \\
\text { de calçados e artefatos de couros e } \\
\text { peles (FIRJAN, 2013). } \\
\text { A cooperativa de fabricantes de } \\
\text { calçados - COOPFARJ, localizada no } \\
\text { município de Duque de Caixas, } \\
\text { composta por } 80 \text { empresas, } \\
\text { localizadas no bairro Lote XV, } \\
\text { demonstra ter capacidade produtiva } \\
\text { para atender a demanda dos dois } \\
\text { municípios. }\end{array}$ & $\begin{array}{l}\text { 1. Aproveita a estrutura já instituída pelo } \\
\text { MDIC de Arranjos Produtivos Locais. A } \\
\text { motivação do Plano Nacional de Cultura para } \\
\text { que a cultura seja um vetor de } \\
\text { desenvolvimento socioeconômico no Brasil, é } \\
\text { um ponto forte para considerar o sapateiro } \\
\text { local uma mão de obra de concepção cultural } \\
\text { à manufatura do calçado escolar. As únicas } \\
\text { modalidades de artesanato que não } \\
\text { gostariamos de considerar seriam os } \\
\text { conceituais e tradicionais, contudo, se for uma } \\
\text { opção das pessoas, serão bem vindas, mas } \\
\text { não o grupo social produtivo intervir em suas } \\
\text { obras ou fazeres. } \\
\text { 1. Os APL's tornam-se responsáveis pelo } \\
\text { desenvolvimento tecnológico personalizado no } \\
\text { seu território e no mais próximo } \\
\text { geograficamente que necessita de ajuda. } \\
\text { 2. O Brasil possui nove Polos calçadistas } \\
\text { distribuídos nas regiões Centro-Oeste, } \\
\text { Nordeste, Sudeste e Sul. } \\
\text { 3. Um município como Novo Hamburgo } \\
\text { (cidade do calçado), reconhecido como o Polo } \\
\text { e cluster calçadista mais importante do Brasil } \\
\text { tem capacidade produtiva para atender sua } \\
\text { auto demanda de forma personalizada. } \\
\text { 4. O Brasil e seus territórios, incluindo os } \\
\text { municípios de Novo Hamburgo e Duque de } \\
\text { Caxias, possuem capacidade produtiva para } \\
\text { manufatura considerando os artesãos } \\
\text { utilitários como mão de obra }\end{array}$ & $\begin{array}{l}\text { 1. Este indicador se refere à necessidade } \\
\text { de desenvolvimento tecnológico para } \\
\text { fabricação de solados escolares, } \\
\text { considerando satisfazer as especificações } \\
\text { técnicas do produto } \\
\text { 2. o mural de economia criativa mostra } \\
\text { que existem } 18.650 \text { trabalhadores } \\
\text { artesanais da confeç̧ão de calçados e } \\
\text { artefatos de couros e peles/Moda, o que } \\
\text { não corresponde às informações dos } \\
\text { agentes sociais do sistema-piloto } \\
\text { 3. Os dados mostram que o território } \\
\text { brasileiro possui capacidade de oferta em } \\
\text { mão de obra e insumos para o sistema de } \\
\text { produção do calçado escolar, desde que } \\
\text { seja realizada uma parceria entre territórios } \\
\text { mais próximos geograficamente possíveis, } \\
\text { especialmente no que se refere à cadeia de } \\
\text { suprimentos do solado, por que: são } \\
\text { poucas as empresas fabricantes }\end{array}$ \\
\hline
\end{tabular}

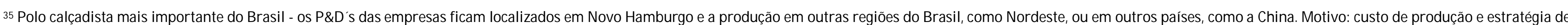
logística de exportação. 


\section{Ajustes no sistema modelo:}

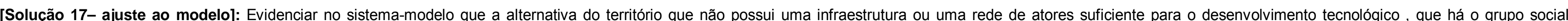
produtivo virtual. Nesse sentido, é imprescindível que se realize as parcerias entre os APL's ou Grupos de Empresas com capacidade tecnológica de atender á distancia tais territórios.

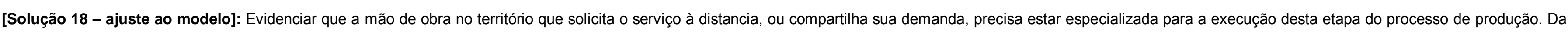

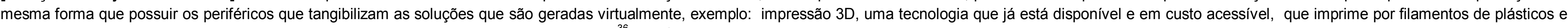
que podem ser reciclados após trabalho com o protótipo. A impressora $3 \mathrm{D}$ custa em média ${ }^{36}$ de $\mathrm{R} \$ 7.000$ reais.

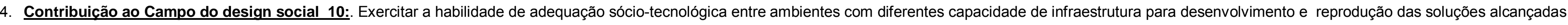
à distância.

Figura 72 - Análise final da fase $3 b$

36 Uma média de preço definida por uma pesquisa realizada no site mercado livre em 2015. A pesquisa priorizou a relação funcionalidade (imprime 3D, disponível no mercado, compatível com qualquer software amigável para projetos 3D, insumos de fácil acesso - cartuchos) e custo (de acordo com a necessidade: tangibilizar a projeto virtual para orientação de seu desenvolvimento e fabricação). 
4.10.8.

\section{Cadeia de suprimentos do sistema de produção (Fase 3)}

O SPPD ao atender uma demanda nacional de produtos de necessidade básica, é um consumidor em grande escala de insumos e serviços. O governo ou o aglomerado de agentes sociais desempenham o papel

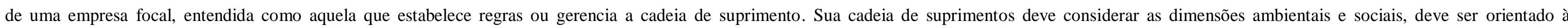
sustentabilidade, tendo, a empresa focal, o papel de induzir práticas socioambientais junto a fornecedores diretos e indiretos.

Contudo, será preciso que a empresa focal tenha a gestão da cadeia de suprimentos orientada por meio de metas sociais e ambientais, atreladas à capacidade de inovação. Para isso, deverão ser convidados fornecedores, nas diversas especialidades representativas para cada componente e processos.

Como o sistema visa o desenvolvimento local pela igualdade de direitos, a formação da cadeira de suprimentos deverá priorizar, a cada necessidade de compra, a chamada pública de fornecedores

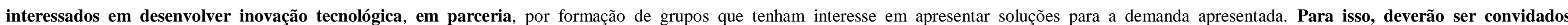

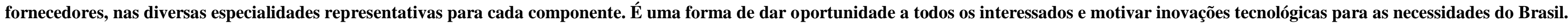

\begin{tabular}{|c|c|}
\hline Sistema Nacional do Calçado & Pontos fortes (que atenderam ao modelo) \\
\hline $\begin{array}{l}\text { Para identificação das alternativas de fabricantes a comporem a } \\
\text { cadeia de suprimentos para produção do calçado escolar, foi feita } \\
\text { investigação no CATMAT. } \\
\text { Não foram encontrados calçados escolares cadastrados no sistema, } \\
\text { mas foram identificados tênis, sem a especificação para uso escolar. } \\
\text { Contudo, não foram identificados calçados escolares e tênis, na } \\
\text { modalidade "item sustentável" no CATMAT. } \\
\text { Para que a cadeia de suprimentos seja orientada por meio de metas } \\
\text { que o desempenho, social e ambiental, esteja atrelado à capacidade } \\
\text { de inovação esta etapa do processo esteve vinculada ao método em } \\
\text { design, especificamente após a projetação do calçado e suas } \\
\text { especificações técnicas descritas no Edital de chamada publica para } \\
\text { formação dos grupos sociais produtivos. }\end{array}$ & $\begin{array}{l}\text { A cada necessidade de compra, o fato de formar novos grupos } \\
\text { sociais produtivos garante a igualdade de direitos a todos os } \\
\text { interessados e é uma forma de motivar inovações tecnológicas para } \\
\text { as necessidades sociais do Brasil. } \\
\text { Não foram encontrados calçados escolares cadastrados no } \\
\text { CATMAT, justificando os objetivos deste sistema à problemática do } \\
\text { calçado escolar, especialmente junto a administração publica. } \\
\text { Contudo foram identificadas compras de fôrmas e matrizes para } \\
\text { injeção de solados catalogadas no CATMAT, o que permite fomento } \\
\text { Governamental a esta etapa do processo de desenvolvimento do } \\
\text { solado para atendimento ao estado de urgência da situação nos } \\
\text { território. }\end{array}$ \\
\hline
\end{tabular}

Pontos fracos (que não atenderam ao modelo e precisam mudar):

\section{Consulta contínua no CATMA}

Quando a empresa focal for o Governo, e seja identificado o cadastro de algum calçado ou calcado escolar na modalidade sustentável do CATMAT, será preciso uma analise comparativa das especificaçōes deste produto com as especificaçōes de acordo, é preciso justificá-la para manter o SPPD do calçado em operação.]

\section{[Solução 19 - ajuste ao modelo]}

\section{Desenvolvimento tecnológico e fabricação do solado}

[Mesmo havendo a oportunidade de compra de matrizes ou formas para a injeção dos solados para compor os calçados escolares de atenção às situaçõ̃es de urgência, torna-se necessário o edital de abertura de licitação ou pregão para compra. Uma condição que deve ser considerada no Edital de implementação da

[Solução 20 - ajuste ao modelo]

\section{Ajustes no sistema modelo:}

[Solução 19 - ajuste ao modelo]: Evidenciar no sistema-modelo que a presença do designer no grupo social produtivo é importante pela habilidade técnica operacional ao utilizar métodos e ferramentas para ecodesign.

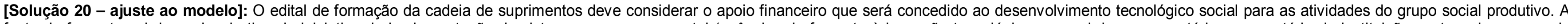

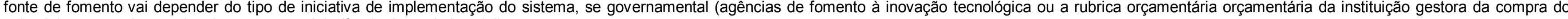
calçado) ou por aglomerados de agentes sociais (fundo do capital social).

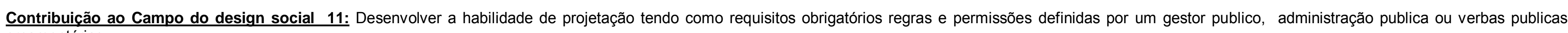
orçamentárias

Figura 73 - Análise final da fase $3 c$ 
4.10.9.

Método em design para projeto do calçado escolar (Fase 3)

A proposta metodológica em design de produto tem como ponto de partida compreender "a situação" ou o estado das pessoas insatisfeitas, como um problema que precisam solucionar, não se fixando a analisar propostas de produtos já existentes.

Tais contextos sociais fazem emergir, ao campo do design, o desafio de encontrar soluções por processos de inovação que tenham a sustentabilidade como meta, sem que as ações tornem-se

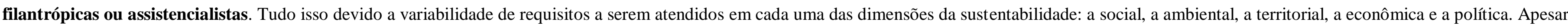
de priorizar o desenvolvimento de inovação em produtos e processos, deve-se considerar que os contextos sociais dos usuários em situação de carência apresentam-se em três estágios.

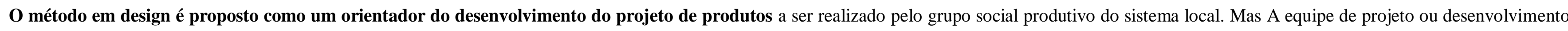
da inovação tecnológica será representada pelo grupo social produtivo, ressaltando a presença do designer.

O método em design subdivide-se em:

a) Planejamento: é feita uma lista de requisitos obrigatórios e desejados. A base é: o problema definido na realidade do público-alvo, nas três características do sistema de produção para cada estágio da situação (urgência, manutenção e sustentabilidade) e na relação destes três fatores com cada dimensão da sustentabilidade

(b) Análise; os requisitos devem ser analisados em função dos insumos disponíveis, das habilidades disponíveis e dos impactos sociais, ambientais e econômicos das alternativas podem ser utilizadas 4 matrizes

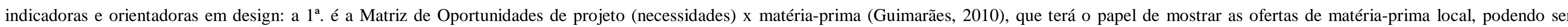

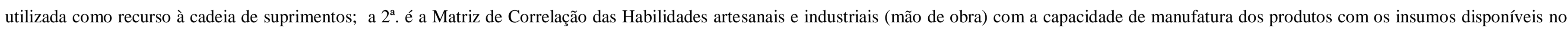
local/ a 3a. Matriz, a SQC - Sustentabilidade, Qualidade e Custo e $4^{\text {a }}$ Matriz, a Morfológica.

c) Projetação; os projetos de inovação, ou redesenho, serão dirigidos pela: definição do problema, os requisitos obrigatórios e desejados, o resultado da matriz que relaciona os tipos de produtos necessários, em cada estágio da situação (urgência, manutenção e sustentabilidade), conforme figura 20.

d) prototipagem e testes. Na Fase (d), as alternativas devem ser prototipadas, para posterior teste de insumos (componentes) e dos processos para fabricação dos produtos. Uma vez aprovadas, as soluções estão prontas para produção. 
Visão nacional para a disponibilidade de mão de obra

Sistema Nacional do Calçado

Planejamento/ Definição do problema: analise da situação coletados, entre 2008 e 2015 , junto aos atores envolvidos na problemática.

Lista de requisitos obrigatórios realizada relacionados à segurança do usuário; custo; e de sustentabilidade, devendo atender as especificações técnicas, com base em normas da ABNT. Assim fol prevista uma Comparação entre os itens do projeto da norma específica de conforto ao calçado escolar do Brasil (CB-11, 2015) (Brezet e Van Hemel, 1997).

Análise - São consideradas as matrizes como instrumento de verificação.

\section{Projetação}

A equipe de projeto são os grupos sociais produtivos locais, ressaltando a presenç do designer.

\section{Prototipagem e testes}

Os grupos devem apresentar protótipos que possam ser realizados ensaios para verificação das especificações contidas no Documento referencial de Projetação, conforme estipulado pela Empresa Foca.

\section{Grupo de NH}

Planejamento/ Definição do problema: foram coletadas informações, em 2015, junto aos atore envolvidos com a problemática localizados no

município.

Alista de requisitos obrigatórios e desejados foi compilada em um ficha tecnica a partir da análise comparada entre as Normas da ABNT para o

calçado escolar e as sete estra téglas de ecodesign,

realizada pela pesquisadora e complementada com

as informações do grupo social produtivo local.

Análise e Projetação - O grupo de NH não quis usar as matrizes, pois disseram ser ferramenta para designer e que poderiam executar a mesma tarefa sem usa-la, como a matriz de oportunidades recursos disponíveis no local. Ela foi usada durante $01^{\circ}$. Encontro do grupo, mas sem a

\section{presença da pesquisadora}

(designer/universidade) ficaria sem registro para um processo sistematizado de projeto.

\section{Prototipagem e testes}

Há ausência de capacidade econômica para desenvolver o solado somente para experimento.

O Sr Fernando construiu uma estratégia de trabalho em grupo, pelo pensamento do produto, porque ele foi buscar também fora do grupo, a oportunidade de formar um novo grupo social com uma família dona de Fabriqueta de calçado.

O grupo de NH desenvolveu - 1 protótipo que atende a situação de urgência, com insumos adquiridos no mercado. Náo priorizaram fazer ensaios para este probipo porque diante o curto presco facilmente atingidas pelo grupo com os inve oferecidos pelo mercado o que difere da versão por inovação (ficha técnica).

$\mathrm{O} 2^{\circ}$. versão deste protótipo

Cesenvolvimento tecnológico do solado insumos, personalizada para atender as especificações da ficha técnica não conseguiram,
Planejamento/ Definição do problema: foram coletadas informações, em 2015, junto aos atores envolvidos com a

A lista de requisitos obrigatórios $\mathrm{e}$ desejados foi compilada em um ficha técnica, a mesma repassada ao grupo de $\mathrm{NH}$.

\section{Análise, Projetação e Prototipagem e} testes

Compreende-se como Grupo social produtivo do território de Duque de Caxias (RJ) a Coopferj - com o grupo de

Empresas, representada pelo Sr Avelino, (

Não conseguiram desenvolver nenhum protótipo, porque no município não poss acessivel para uma compra de urgência que atenda a especificaçõ̃es mínimas de que atenda a especificaçôes minimas calçado. Dificultando ainda mais, se desejam um desenvolvimento de produto técnica.

Motivo que levou ao grupo a dizer: não queremos apresentar "porcaria". Apesa da boa vontade do Sr. Avelino. É preciso investir em tecnologia diz ele.

O Município não possui a mínima infraestrutura para atendimento ao desenvolvimento de inovação para

Há um movimento para formação do APL do Calçado no município.
Pontos fortes (que atenderam ao modelo):

O método em design prevê que o calcado seja fabricado, em um ciclo de vida ampliado com a manutenção, e no pós-uso que seja desmontado e reaproveitadas cada parte, industrial e reincorporados como matéria-prima em novos ciclos produtivos.

2. O fato do calçado estar determinado, pela Norma, a durar no mínimo o tempo previsto no código do consumidor justifica o conceito de produto do SPPD do calçado.

3.O manejo do resíduo orgânico para o processo biológico de reciclagem terá como destino as composteiras locais, gerando trabalho e renda no território com esta atividade. .A comparação entre a norma CB-11 e as consistencia e clareza aos requisitos obrigatórios.

5.0 modelo de tênis proposto pela norma quanto às estratégias do ecodesign possui partes, há oportunidade de melhorias com minimização da quantidade de componentes usando a ficha técnica desenvolvida na comparação entre as normas da ABNT e as sete estratégias de ecodesign.

A relação das pessoas do grupo social produtivo com o local, que se confirmou conforme previsto no sistema-modelo. A exemplo a postura do S Fernando (o modelista de cabedal) que firmou um novo grupo social produtivo para $\mathrm{NH}$. importancia das pessoas pro-ativas. . SPPD ao nivel nacional, por iniciativa govado contribui em disseminer práticas que beneficiam fatores disserninar prálicas que denvolvimento da inovacão tecomo motivar o nos Pais através de solucões sustentáveis em custo e relações sócio-ambientais. 7.A proposta da $3^{\mathrm{a}}$ caracteristica estratégica do sistema que se apresentou imprescindível após os resultados do experimento.
Pontos fracos (que não atenderam ao modelo e precisam mudar):

A exigência das especificações A cricas, com referência nas Normas da ABNT do calçado

[A referência para determinar os parâmetros de medição das normas do calçado é durar no mínimo o tempo previsto no codigo do

consumidor. Construindo uma relação com a obsolescência programada e náo priorizar o atendimento a necessidade do público-alvo e as dimensões de sustentabilidade.

[Solução 21 - ajuste ao modelo]

Relação da exigência de requisito e competitividade entre licitantes

[A exigência dos requisitos não devem frustrar a competitividade entre os licitantes, mesmo que os requisitos obrigatórios sejam para selecionar a alternativa mais vantajosa para a compra do calçado escolar.]

[Solução 22 - ajuste ao modelo]

Necessidade de Desenvolvimento tecnológico e ausência de 列 para desenvolvimento

[Demonstra a necessidade parceria entre todos os portes de empresa produc̃a distribuída pela quantidade de empresas detentora desta tecnologia no Brasil]

\section{Desenvolvimento de inovação}

Se os demais atores da rede em formato da Helice Tripla Dupla 


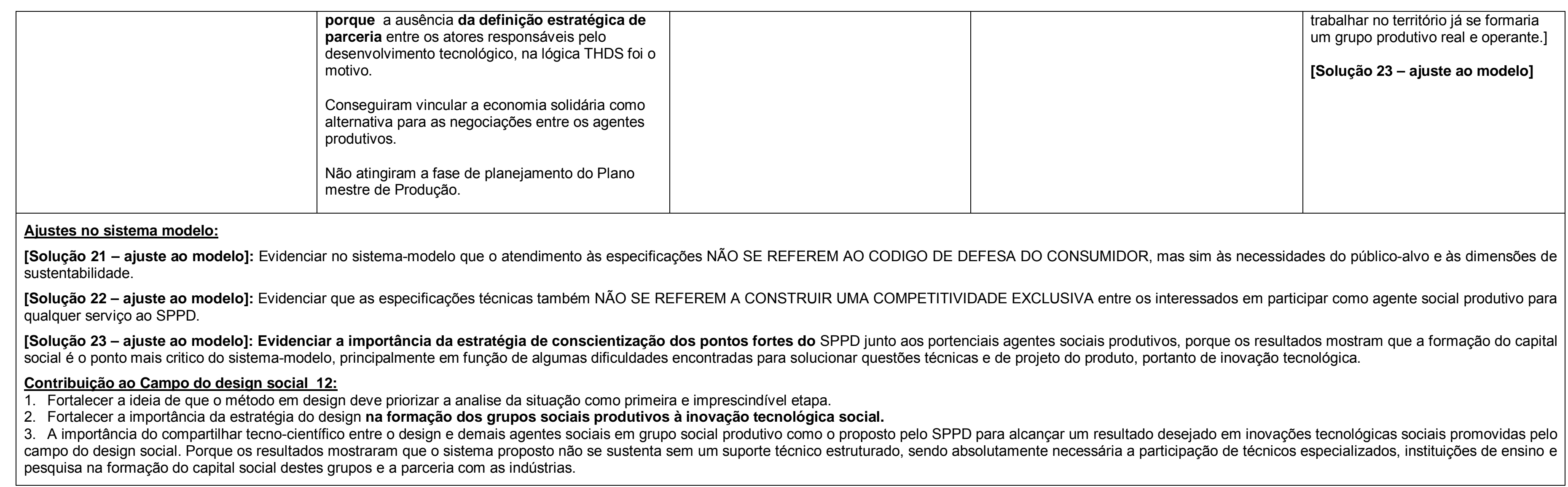

Figura 74 - Análise final da fase 3d 


\section{5 Considerações finais da tese}

Esta tese abordou a problemática do design, produção e distribuição de produtos de média complexidade para pessoas que não tem necessidades básicas atendidas. Estes produtos geralmente são de vestuário, auxilio a vida diária, educação, saúde, segurança e lazer, sendo que muitos são de responsabilidade do governo, conforme a Constituição Brasileira. O público alvo é mais de $20 \%$ da população brasileira pois engloba não só os 39.150 .981 pobres ou extremamente pobres, mas também aqueles que, apesar de ter meios de sobrevivência, também não são atendidos ou não podem arcar com o custo de produtos caros. Este grupo, no entanto, pode adquirir produtos importantes para sua saúde e segurança, se forem comercializados a um preço justo.

Com base na revisão de literatura sobre design e inovação social, e na análise de produtos desenvolvidos no Brasil e no exterior, esta tese propôs um sistema de design e produção distribuída (SPPD) que pudesse orientar decisões projetuais sustentáveis que atendessem a demanda por estes produtos básicos. $\mathrm{O}$ pensamento em design que orientou o processo de desenvolvimento do sistema, em consonância com a literatura do design e outras disciplinas que dialogaram, propôs, como estratégia do SPPD, a formação de um capital social para legitimar, com interveniência de designers e outros profissionais de instituições cientificas e tecnológicas, as ações de um grupo social produtivo local. Este é composto pelas empresas fabricantes de insumos e produtos, bem como pelos artesãos locais, pertencentes ou não à formação dos Arranjos Produtivos Locais (APL's), para atender, de forma customizada, as demandas de cada território.

O referencial teórico informava que um grupo mínimo de atores é imprescindível para a inovação tecnológica social. Por exemplo, apenas com uma rede entre universidade-governo-empresa-sociedade é possível garantir o alcance dos objetivos. Alguns projetos brasileiros, especialmente aqueles que foram desenvolvidos para atenção básica, não foram implementados porque faltou o planejamento estratégico para definir a rede de atores. 
A proposta do sistema é, portanto, garantir a operação em rede de atores, unir o potencial das empresas e da produção artesanal, para suprir necessidades locais com recursos locais, contribuindo assim para o desenvolvimento local pela geração de trabalho e renda, utilização de conhecimento endógeno e de recursos locais (ou quanto mais próximo geograficamente). O sistema tem 3 características estratégicas: ênfase na responsabilidade governamental, oportunizar o desenvolvimento local, e motivar a cooperação entre os agentes sociais para a inovação tecnológica. Ele propõe que as ações se deem em curto prazo (para atender a situações de urgência), médio (para desenvolvimento humano) e longo prazo (para manutenção do estado de desenvolvimento humano, ou de sustentabilidade).

A demanda se dá por iniciativa governamental ou aglomerados de agentes sociais, por meio de chamada publica. O demandante estabelece os requisitos para produção e aquisição do produto. A fim de atender as demandas locais e o desenvolvimento local, o sistema incorpora o capital e o grupo social produtivo (composto pelo governo, designers, agentes locais) dentro da filosofia da produção distribuída. O papel do demandante é definir as políticas de aquisição e impulsionar a demanda, o do designer/universidade é de definir os requisitos técnicos, identificar as necessidades dos usuários e customizar o projeto para atender as necessidades dos territórios, junto com o grupo social produtivo a quem cabe a produção em cada território sob a gerencia da empresa focal.

O SPPD foi colocado em prática considerando o calçado escolar como estudo de caso. Calçado é um item caro, mas necessário para garantir a saúde e segurança dos cidadãos. O Brasil é o terceiro maior produtor de calçados do mundo, mas o governo não consegue garantir a compra de calçados escolares a um preço justo porque as normas técnicas brasileiras que definem as especificações técnicas do calçado oneram o preço do produto colocando exigindo o uso de componentes desnecessários e que não constam da demanda dos usuários. A título de atender esta demanda, os responsáveis pela execução do projeto, que são o governo ou aglomerados de agentes sociais, podem abrir uma licitação, com as especificações técnicas necessárias (estabelecidas pelo designer e com amparo nas especificações estabelecidas por órgãos competentes). Os componentes mais complexos (o solado, no caso do calçado) são fabricados por indústrias de componentes calçadistas que já detém a tecnologia. A montagem e 
manutenção do produto é feita localmente, utilizando os artesãos locais (os sapateiros, no caso do calçado). A distribuição do componente é feita pelo fabricante, já a distribuição do calçado fabricado é feita pelo agente social fabricante ou pelas Unidades Executoras locais (como as escolas) determinadas pela Empresa Focal e grupo social produtivo. Utilizando a logística reversa, o take back é realizado por agentes sociais definidos a este serviço ou pelos artesãos, ambos responsáveis pela coleta, desmonte do produto, separação e envio dos componentes reaproveitáveis para as fábricas ou para a compostagem local.

Com base na experiência com o calçado, ficou claro que independente da disponibilidade dos recursos, como mão de obra (conhecimento técnico, científico ou tácito) e matéria prima, o sistema não se sustenta se não houver relações sociais estruturadas. Tais relações são de ordem macro, quando representadas pelas interações entre as instituições governamentais (federais, estaduais e municipais), organizacionais (setores produtivos brasileiros) e de coletivos sociais (fóruns de movimentos sociais) e de ordem micro, quando o ponto de comunicação e informação é uma pessoa de referência do local. Tal formatação de relações sociais torna o sistema proposto flexível, e portanto generalizável podendo ser implantado em diferentes territórios utilizando os recursos locais ou não, e com gerenciamento local ou central à distância, seguindo o conceito de produção distribuída.

Além da importância da rede de atores, a experiência com o projeto do calçado revelou que é imprescindível um designer/projetista no sistema, para definir os requisitos básicos de projeto e orientar a customização. Os artesãos, que devem formar o capital social produtivo no sistema proposto, tem o saber fazer, domínio de materiais e dos processos pouco complexos mas não conseguem traduzir as especificações técnicas. Portanto, o SPPD prevê que as especificações e o projeto customizado para a produção de produtos em cada território sejam coordenadas pelos designers. A territorialização em um país de grande extensão geográfica quanto o Brasil não é um problema porque hoje há a facilidade de integração pelas tecnologias virtuais, como preconizado pela produção distribuída.

\section{Pesquisas futuras}

Durante o desenvolvimento desta tese surgiram oportunidades para dar continuidade à ação prática experimental do SistemaPPD, em primeiro momento 
com os municípios que participaram da pesquisa, dando ênfase ao desenvolvimento de projetos de pesquisa, ensino e extensão, em parceria com os cursos de design das universidades da região, a fim de gerar e ampliar as contribuições tecno-científicas à sociedade local e ao campo do design.

Em conclusão, há a intenção de apresentar os resultados desta pesquisa à equipe de compras do FNDE como contribuição ao processo de aquisição nacional do calçado escolar, bem como aos processos dos demais produtos de média complexidade de apoio à educação licitados pela instituição. 


\section{6 Referências}

ABDI - AGÊNCIA BRASILEIRA DE DESENVOLVIMENTO INDUSTRIAL. Política de Desenvolvimento Produtivo. Disponível em: <http://www.abdi.com.br/Paginas/politica_industrial.aspx>. Acesso em: 24 jun. 2015.

ABICALÇADOS - Associação das Indústrias de Calçados e Afins. Cartilha Indústria de Calçados do Brasil 2012. Novo Hamburgo: 2012. Disponível em:

<http://www.abicalcados.com.br/site/inteligencia.php>. Acesso em 24 out. 2015.

ALBAGLI, S.; MACIEL, M. L. Capital social e empreendedorismo local. In: Lastres, H. M. M.; Cassiolato, J. E.; Maciel, M. L. Pequena Empresa: cooperação e desenvolvimento local. p. 3. Rio de Janeiro: REDSIST, 2002. Disponível em: <

http://www.ie.ufrj.br/redesist/NTF2/NT\%20SaritaMLucia.PDF>. Acesso em: 05 set. 2015.

ALBUQUERQUE, E. M. Idéias fundadoras. v. 3, n.1. São Paulo: Revista Brasileira de Inovação, 2004. p. 9-13. Disponível em:<http://ocs.ige.unicamp.br/ojs/rbi/article/view/264/180>. Acesso em: 06 out. 2015 .

ALBUQUERQUE, P. P. Elementos para repensar el concepto de autogestión. In: Economía social y solidaria : praxis, vivencias e intenciones. Rosario: Universidade Nacional de Rosario, Ediciones Del Revés, 1 ed. , p. 392-393, 2014. p. 464. Disponível em:<http://docplayer.es/933051-Edicionesdelreves-economia-social-y-solidaria-praxis-vivencias-e-intenciones.html> Acesso em: 07 out.2015.

ALBURQUERQUE, F. Marco conceitual e estratégia para o desenvolvimento local. In: Desenvolvimento Local e Participação Social, Zapata, Tania (org.). Recife: Editora Livro RápidoElógica, 2007. Disponivel

em: <https://ppintervencaoterritorial.files.wordpress.com/2015/02/alburquerque22.pdf >. Acesso 07 set.2015.

AMARAL FILHO, J. Sistemas e arranjos produtivos locais. In: Planejamento e políticas públicas, n. 36, 2011. Disponível em: <http://www.ipea.gov.br/ppp/index.php/PPP/\%E2\%80\%A8article/viewFile/226/20>. Acesso em: 20 jun. 2015.

AMARAL, J. A endogeneização no desenvolvimento econômico regional e local. n. 23. Brasília: IPEA, Planejamento e políticas públicas, 2001. Disponível em: <www.ipea.gov.br/ppp/index.php/PPP/article/view/78/89>. Acesso em: 05 set.2015.

ANDRADE, T. N. Aspectos Sociais e Tecnológicos das Atividades de Inovação, Lua Nova, n. 66, p. 139-166, 2006. p. 148. Disponível em: 〈http://www.scielo.br/pdf/ln/n66/29087.pdf〉. Acesso em: 10 out.2015.

ANDRÉ, I.; ABREU, A. Dimensões e espaços da inovação social. v. XLI, n. 81. Lisboa: Finisterra, 2006. p. 121-141. Disponível em:<http://www.ceg.ul.pt/finisterra/numeros/200681/81_06.pdf>. Acesso em: 05 set. 2015.

ANGOLA, C. Cisternas garantem água em escolas do Semiárido. Recife:Ed. Articulação Semiárido Brasileiro (ASA), ASCOM, 2015. Disponível em:<http://www.asabrasil.org.br/noticias?artigo_id=7094> Acesso em 15 ago. 2015.

ARANTES, R. S. Os Cuidados na Comprovação dos Requisitos de Sustentabilidade. In: MINISTÉRIO DO PLANEJAMENTO: Compras Governamentais, Capacitação. Brasília: EPPGG, 2014. Disponível em: <http://www.comprasgovernamentais.gov.br/arquivos/capacitacao/3-oscuidados-na-comprovacao-dos-requisitos-de-sustentabilidade.pdf $>$. Acesso em: 25 set. 2015. 
ARAÚJO, C. M. Biodigestores em Escolas Públicas: Uma Ideia Energética. Rio de Janeiro: BANCO DE TECNOLOGIAS SOCIAIS DA FBB, 2011. Disponível em: <http://www.fbb.org.br/tecnologiasocial/banco-de-tecnologias-sociais/pesquisartecnologias/biodigestores-em-escolas-publicas-uma-ideia-energetica.htm>. Acesso em 07 ago. 2015.

BANCO DO BRASIL. Banco de Tecnologias do Banco do Brasil. FBB, 2015. Disponível em:<http://www.fbb.org.br/tecnologiasocial/>. Acesso em: 03 ago. 2015.

BANCO PALMAS. A Moeda Social Eletrônica do Banco Palmas: e-dinheiro. Fortaleza: 2015. Disponível em:<http://www.institutobancopalmas.org/e-dinheiro/> Acesso em 22 set.2015.

BARBOSA, R. A questão social e politica no Brasil. Rio de Janeiro: Casa Rui Barbosa, 1919.

BARROSO NETO, Eduardo. O que é artesanato? In: Curso de Artesanto, Modulo 1, p. 4-5, 2001. Disponível em: <http://www.fbes.org.br/biblioteca22/artesanato_mod1.pdf>. Acesso em: 05 set. 2015.

BERTONCELLO, I; GOMES, L. V. N. Análise diacrônica e sincrônica da cadeira de rodas mecanomanual. IN: Revista Produção. vol. 12, n. 1, p. 74, 2002, p 72-84. Disponível em: < http://www.readcube.com/articles/10.1590\%2Fs0103-65132002000100007> Acesso em: 09 out. 2015.

BETIOL, L. S. et al. Compra Sustentável: a força do consumo público e empresarial para uma economia verde e inclusiva. 1. ed. p. 56-57. São Paulo: Gestão Pública e Cidadania, FGV-EAESP, 2012. Disponível em: <http://ghgprotocolbrasil.com.br/compra-sustentavel-a-forca-do-consumopublico-e-empresarial-para-uma-economia-verde-e-inclusiva?locale=pt-br $>$ Acesso em 06 out. 2015.

BHATTACHARYA C. B.; KORSCHUN D.; SEN S. Using Corporate Social Responsibility to Win the War for Talent. MIT Sloan Management Review. v. 49(2), p. 37-44. 2008. Disponível em:< http://sloanreview.mit.edu/article/using-corporate-social-responsibility-to-win-the-war-fortalent/>. Acesso em: 05 set. 2015.

BIDERMAN, R. et al. Guia de compras públicas sustentáveis: Uso do poder de compra do governo para a promoção do desenvolvimento sustentável. 2. ed. Brasília, DF: Ministério do Meio Ambiente, 2008. Disponível em: <

http://cpsustentaveis.planejamento.gov.br/assets/conteudo/uploads/compraspublicas2aed5aprova.p df>. Acesso em: 11 abr. 2014.

BIGNETTI, L. P. As inovações sociais: uma incursão por ideias, tendências e focos de pesquisa. Ciências Sociais Unisinos. v. 47, n.1, p. 4-6. São Leopoldo: 2011. Disponível em: $<$ http://revistas.unisinos.br/index.php/ciencias_sociais/article/viewFile/1040/235>. Acesso em: 04 ago. 2015.

BOEIJEN, A. V. Delft Design Guide. Holanda: Delft University of Technology, 2014.

BONSIEPE, G. Design como prática de projeto: São Paulo, Ed. Blucher, p. prefácio, 2012, p. 216.

BORJA DE MOZOTA, B. Design management: using design to build brand value and corporate innovation. New York: Allworth Press, 2003.

BRASIL. Constituição (1988). Art. 205. Prevê o dever do Estado com a educação. Brasília, DF: Presidência da República: Casa Civil, 1988. Disponível em:

<http://www.planalto.gov.br/ccivil_03/constituicao/ConstituicaoCompilado.htm> Acesso em: 30 jun. 2010.

. Constituição (1988). Art. 208, inciso vii. Prevê o dever do Estado com a educação.

Brasília, DF: Presidência da República: Casa Civil, 1988. Disponível em: <http://www.planalto.gov.br/ccivil_03/constituicao/ConstituicaoCompilado.htm> Acesso em: 30 jun. 2010.

DECRETO DE 25 DE FEVEREIRO DE 2008. Art. $1^{\circ}$., $\S 2^{\circ}$, Institui o Programa Territórios da Cidadania. Brasília, DF:Presidência da República: Casa Civil, 2008. Disponível em: <http://www.territoriosdacidadania.gov.br/dotlrn/clubs/territriosrurais/filestorage/file?file_id=9085852>. Acesso em: 04 jun. 2015. 
. Decreto $\mathrm{n}^{\circ}$ 591, de 6 de julho de 1992. Atos Internacionais. Pacto Internacional sobre Direitos Econômicos, Sociais e Culturais. Promulgação. Brasília, DF: Presidência da República, 1992. Disponível em:< http://www.planalto.gov.br/ccivil_03/decreto/1990-1994/D0591.htm>. Acesso em:

DECRETO No 7.746, DE 5 DE JUNHO DE 2012. Regulamenta o art. 3o da Lei no 8.666, de 21 de junho de 1993, para estabelecer critérios, práticas e diretrizes para a promoção do desenvolvimento nacional sustentável nas contratações realizadas pela administração pública federal, e institui a Comissão Interministerial de Sustentabilidade na Administração Pública CISAP. Brasília, DF: Presidência da República: Casa Civil, 2012. Disponível em: <http://www.planalto.gov.br/ccivil_03/_ato2011-2014/2012/decreto/d7746.htm>. Acesso em: 05 out. 2015.

. LEI COMPLEMENTAR No 101, DE 4 DE MAIO DE 2000. Estabelece normas de finanças públicas voltadas para a responsabilidade na gestão fiscal e dá outras providências. Brasília, DF: Presidência da República: Casa Civil, 2014. Disponível em: <http://www.planalto.gov.br/ccivil_03/leis/LCP/Lcp123.htm\#art88>. Acesso em: 25 jun. 2015.

. LEI COMPLEMENTAR Nº 123, DE 14 DE DEZEMBRO DE 2006. Institui o Estatuto Nacional da Microempresa e da Empresa de Pequeno Porte: Esta Lei Complementar estabelece normas gerais relativas ao tratamento diferenciado e favorecido a ser dispensado às microempresas e empresas de pequeno porte no âmbito dos Poderes da União, dos Estados, do Distrito Federal e dos Municípios. Brasília, DF: Presidência da República: Casa Civil, 2014. Disponível em: <http://www.planalto.gov.br/ccivil_03/leis/LCP/Lcp123.htm\#art88>. Acesso em: 25 jun. 2015.

LEI No 11.947, DE 16 DE JUNHO DE 2009. Dispõe sobre o atendimento da alimentação escolar e do Programa Dinheiro Direto na Escola aos alunos da educação básica. Brasília, DF: Presidência da República: Casa civil, 1988. Disponível em : <http://www.planalto.gov.br/ccivil_03/_ato2007-2010/2009/lei/111947.htm>. Acesso em : 30 jun. 2010 .

LEI N ${ }^{\circ}$ 12.305, DE 2 DE AGOSTO DE 2010. Institui a Política Nacional de Resíduos Sólidos. Brasília, DF: Presidência da República: Casa Civil, 1988. Disponível em: <http://www.planalto.gov.br/ccivil_03/_ato2007-2010/2010/lei/112305.htm>. Acesso em: 03 mar. 2014.

LEI No 12.343, DE 02 DEZEMBRO DE 2010. Institui o Plano Nacional de Cultura PNC, cria o Sistema Nacional de Informações e Indicadores Culturais - SNIIC e dá outras providências.Brasília, DF: . Disponível em: <http://www.cultura.gov.br/documents/10907/963783/Lei+12.343++PNC.pdf/e9882c97-f62a40de-bc74-8dc694fe777a>. Acesso em: 07 out. 2015.

LEI N $^{\circ}$ 12.349, DE 15 DE DEZEMBRO DE 2010. Altera as Leis nos 8.666, de 21 de junho de 1993, 8.958, de 20 de dezembro de 1994, e 10.973, de 2 de dezembro de 2004; e revoga o $\S 1$ o do art. 20 da Lei no 11.273, de 6 de fevereiro de 2006. Brasília, DF: Presidência da República: Casa Civil, 2015. Disponível em: <http://www.planalto.gov.br/ccivil_03/_Ato20072010/2010/Lei/L12349.htm>. Acesso em 25 set. 2015.

. LEI No 8.666, DE 21 DE JUNHO DE 1993. Art. 3, redação dada pela Lei no 12.349, de 2010. Brasília, DF: Presidência da República: Casa Civil, 1988. Disponível em : <http://www.planalto.gov.br/ccivil_03/Leis/L8666cons.htm>. Acesso em :25 ju. 2013.

. LEI No 8.742, DE 7 DE DEZEMBRO DE 1993. Lei Orgânica da Assistência Social LOAS: Dispõe sobre a organização da Assistência Social e dá outras providências. Brasília, DF: Presidência da República: Casa Civil, 1988. Disponível em: <http://www.planalto.gov.br/ccivil_03/LEIS/L8742compilado.htm>. Acesso em: 25 jun. 2015.

.Constituição (1988). Art. 7, inciso iv. Capítulo II - Dos Direitos Sociais. Brasília, DF: Presidência da República: Casa Civil, 1988. Disponível em: <http://www.planalto.gov.br/ccivil_03/constituicao/ConstituicaoCompilado.htm>. Acesso em : 30 jun. 2015.

BREZET, H.; VAN HEMEL, C. EcoDesign: A Promising Approach to Sustainable Production and Consumption. Paris: UNEP, 1997. 
CALDAS, E. L.; NONATO, R. S. Compras Públicas em favor do desenvolvimento local: O Caso de Osasco. In: CONGRESSO INTERNACIONAL INTERDISCIPLINAR EM SOCIAIS E HUMANIDADES. Rio de Janeiro: ANINTER-SH/ PPGSD-UFF, 2012. Disponível em: <http://webcache.googleusercontent.com/search?q=cache:UQ10AVS7hT4J:www.aninter.com.br/A NAIS \%2520I\%2520CONITER/GT02\%2520Gest\%25E3o,\%2520pol\%25EDticas\%2520p\%25FAb licas $\% 2520 \mathrm{e} \% 2520$ sociais/COMPRAS $\% 2520 \mathrm{P} \% 25 \mathrm{DABLICAS} \% 2520 \mathrm{EM} \% 2520 \mathrm{FAVOR} \% 2520$ DO\%2520DESENVOLVIMENTO\%2520LOCAL\%2520O\%2520CASO\%2520DE\%2520OSASC O-\%2520Trabalho\%2520completo.pdf $+\& \mathrm{~cd}=3 \& \mathrm{hl}=\mathrm{pt}-\mathrm{BR} \& \mathrm{ct}=\mathrm{clnk} \& \mathrm{gl}=\mathrm{br}>$. Acesso em: 13 ago. 2015.

CARRASCO, J.M. Engenharia do Produto: sistemas de fabricação I, 1970. 154 p.

CARVALHO, A. P. GESTÃO SUSTENTÁVEL DE CADEIAS DE SUPRIMENTO: análise da indução e implementação de práticas socioambientais por uma empresa brasileira do setor de cosméticos: Tese de doutorado. São Paulo: FUNDAÇÃO GETULIO VARGAS ESCOLA DE ADMINISTRAÇÃO DE EMPRESAS DE SÃO PAULO, 2011. p. 187. Disponível em: $<$ https://s3-sa-east1.amazonaws.com/arquivos.gvces.com.br/arquivos_gvces/arquivos/231/Tese_Andre_Pereira_de_ Carvalho.pdf>. Acesso em: 23 ago. 2015.

CASSIOLATO, J. E.; MATOS, M. P. Política brasileira para arranjos produtivos locais: o aprendizado acumulado e suas perspectivas. In: A Nova Geração de Políticas de Desenvolvimento Produtivo Sustentabilidade Social e Ambiental. Brasília: CNI, 2012. p.192. Disponível em: < http://www10.iadb.org/intal/intalcdi/PE/2013/10891.pdf>. Acesso em: 19 ago. 2015.

CASTIONI, R. A. Educação dos trabalhadores nos APL's: convergência de políticas e construção de itinerários formativos. Apresentado parcialmente sob o título: Educar para o emprego educar para o (des)emprego: a trajetória das políticas de educação voltadas ao mercado de trabalho na última década. In: XI Congresso - Federação Internacional de Estudos Sobre a América Latina e Caribe. Japão, Osaka: XI Congresso - FIEALC, 2003. Disponível em: $<$ http://www.fe.unb.br/catedraunescoead/quem-equem/docentes/r/remi/publicacoes/8_Educacao_APLS.pdf>. Acesso em: 19 ago. 2015.

CLARK K. B. and WHEELWRIGHT S. C. (Editors) The Product Development Challenge: Competing Through Speed, Quality and Creativity. Boston: Harvard Business School Publishing, 1994. p. 431

CLOUTIER, J. Qu'est-ce que l'innovation sociale? In: Collection Études théoriques. n. ET0314. Canadá: Crises, 2003. Disponível em: <https://crises.uqam.ca/upload/files/publications/etudestheoriques/CRISES_ET0314.pdf>. Acesso em: 18 jul. 2015

COSTA, A. S. Cisternas nas escolas. Bahia: Banco de tecnologias sociais da Fundação Banco do Brasil, 2011. Disponivel em: < http://www.fbb.org.br/tecnologiasocial/banco-de-tecnologiassociais/pesquisar-tecnologias/cisternas-nas-escolas.htm>. Acesso em: 08 jul. 2015.

CRUZ, B. P. A.; PITHON, C. F. C. M. Os Reflexos da Crise Financeira nas Práticas de Responsabilidade Social de Empresas dos Setores de Energia Elétrica e Bancário que Compõem o Índice de Sustentabilidade Empresarial da BM\&FBovespa. In: Anais Eletrônicos do XXXIII Encontro Anual da ANPAD, p. 4-5, 2009. Disponível em:<http://www.anpad.org.br/admin/pdf/ESO1837.pdf> Acesso em: 10 ago. 2009.

CZELUSNIAK, V. A.; Cordeiro, P. V. M; Dergint, D. A. Contribuições dos quadros teóricos da tríplice hélice e dos estudos da ciência, tecnologia e sociedade para políticas de inovação tecnológica na América Latina. Buenos Aires: IN: ESOCITE 2010. VIII JORNADAS LATINOAMERICANAS DE ESTUDIOS SOCIALES DE LA CIENCIA Y TECNOLOGÍA, 2010. Disponível em:< http://www.esocite2010.escyt.org/sesion_ampliada.php?id_Sesion=83\#> Acesso em: 05 out.2015.

DAGNINO, R. P et al. Sobre o marco Analítico-conceitual da tecnologia social. In: Tecnologia social: uma estratégia para o desenvolvimento. P. 14; 54-57. Rio de Janeiro: Fundação Banco do Brasil, 2004.

DAGNINO, R. P. Adequação Sociotecnologica: tecnologia social. In: Ciclo de Conferências Teoria Crítica da Tecnologia. Universidade Brasília, 2010. Disponível em: <http://www.youtube.com/watch?v=Lq_DA1_00NE> Acesso em: 05 set. 2013. 
DAGNINO, R. P. Tecnologia social: retomando um debate. Espacios. v. 27 (2), p. 16-18-20. Brasília: 2006. Disponivel em:< http://www.revistaespacios.com/a06v27n02/06270231.html> Acesso em: 05 ago. 2013.

DAGNINO, R; Tecnologia social : ferramenta para construir outra sociedade. 2 ed. São Paulo, Campinas: Komedi, 2010.

DIEESE - Departamento Intersindical de Estatística e Estudos Socioeconômicos. Custo da Cesta básica tem comportamento diferenciado nas capitais pesquisadas. In: Cesta Básica de Alimentos, Resultados Mensais de 2015, 2015. Disponível em: <http://www.dieese.org.br/analisecestabasica/2015/201510cestabasica.pdf> Acesso em: $20 \mathrm{dez}$. 2015.

ETZKOWITZ, H.; LEYDESDORFF, L. Emergence of a triple helix of university -industry government relations. Science and Public Policy, v. 23, n. 5, p. 279-286, 1998.

ETZKOWITZ, H; ZHOU, C. Triple Helix twins: innovation and sustainability. Science and Public Policy, Surrey, v. 33, n. 1, p. 77-83, 2006.Disponível em: http://spp.oxfordjournals.org/content/33/1/77.abstract> Acesso em: 15 ago.2015.

FEITOSA, C. O. Aglomerações Industriais como fator de desenvolvimento regional: um estudo de caso no Nordeste brasileiro. Espanha: Ed. EUMED.NET - Biblioteca Virtual de Derecho, Economía y Ciencias Sociales, p. 11-12, 2009. Disponível em: <http://www.eumed.net/libros/2009a/521> Acesso em: 10 set. 2015.

FERREIRA, A. B. H. Mini dicionário Aurélio de Língua Portuguesa. Positivo, 2014. 960 p.

FIGUEIREDO P. N. ACUMULAÇÃO TECNOLÓGICA E INOVAÇÃO INDUSTRIAL conceitos, mensuração e evidências no Brasil. v. 19, n. 1, p. 54-69, jan./mar. 2005. São Paulo: 2005. p. 54. Disponível em: <http://www.scielo.br/pdf/spp/v19n1/v19n1a05.pdf>. Acesso em:

FILHO, A. P. D. F.; FARIAS, F. M. H.; ARAÚJO, P. M. M. Fogão Solar. In: Banco de Tecnologias da Fundação Banco do Brasil. Disponível em: $<$ http://www.fbb.org.br/tecnologiasocial/banco-de-tecnologias-sociais/pesquisartecnologias/fogao-solar.htm>. Acesso em: 13 out. 2015.

FNDE - Fundo Nacional de Desenvolvimento da Educação. Sobre o Programa Nacional de Alimentação Escolar (PNAE). Disponível em: <http://www.fnde.gov.br/index.php/programas/alimentacao-escolar/alimentacao-escolarapresentacao>. Acesso em: 13 set. 2015.

. Audiência Pública no 9/2011 - Uniforme Escolar. Brasília, DF: FNDE. Diponível em: <http://www.fnde.gov.br/portaldecompras/index.php/editais/audiencias-publicas/audienciaspublicas-2011/item/342-audiencia-publica-n-9-2011-uniforme-escol>. Acesso em: 25 jun. 2015.

FNDE. Uniforme escolar: apresentação. Brasília, DF: FNDE, 2012. Diponível em: <http://www.fnde.gov.br/portaldecompras/index.php/produtos/uniformes-escolares >. Acesso em: 20 mai. 2015.

FOGLIATTO, F; GUIMARÃES, L.B.M. Design Macroergonômico: uma proposta metodológica para projeto de produto. Produto \& Produção. v.3, n. 3. Porto Alegre: PPGEP UFRGS, 1999.

FRANZATO, C. O processo de inovação dirigida pelo design: um modelo teórico, REDIGE, v. 2, n. 1, 2011. Disponível em: <

http://www2.cetiqt.senai.br/ead/redige/index.php/redige/article/viewFile/72/138>. Acesso em: 05 jul. 2015.

FREEMAN, C. The "National Systems of Innovation" in historical perspective. Cambridge Journal of Economics 1995, v. 19, p. 5-24. Disponível em:

<http://www.globelicsacademy.org/2011_pdf/Freeman\%20NSI\%20historial\%20perspective.pdf>. Acesso em:

FREIRE, K. M. DESIGN ESTRATÉGICO: ORIGENS E DESDOBRAMENTOS. p. 2815-2829 . In: Anais do $11^{\circ}$ Congresso Brasileiro de Pesquisa e Desenvolvimento em Design. v. 1, n. 4. São Paulo: Blucher, 2014.

FREIRE, M. V. Moedas sociais: contributo em prol de um marco legal e regulatório para as moedas sociais circulantes locais no Brasil. Brasília: Faculdade de Direito, 2011. Disponível em:< 
http://repositorio.unb.br/bitstream/10482/9485/1/2011_MarusaVasconcelosFreire.pdf>. Acesso em: 03 ago. 2015.

FUNDAÇÃO CENTRO TECNOLÓGICO DE MINAS GERAIS - CETEC. Projeto Juramento: Prática de Implantação e Disseminação de Tecnologia Apropriada ao Meio Rural. Minas Gerais, Belo Horizonte: CETEC, FINEP, 1985.

FUNDAÇÃO GETÚLIO VARGAS. Estratégias para Aquisição de Uniformes Escolares. In: Relatório Preliminar: Fundo Nacional de Desenvolvimento da Educação. Brasília, DF: Ministério da Educação, 2010. p. 37

GIL, A. C. Como elaborar projetos de pesquisa. 4 ed. São Paulo: Atlas, 2002.

GUIMARÃES, L.B.M. Polos Sustentáveis no Rio Grande do Sul sob enfoque Zeri. Projeto CNPq número do Processo: 504183/2008-7, 2008.

GUIMARÃES, L.B.M. Sociotechnical design for sustainable development. In: Design and sustainability. Porto Alegre: FEENG, 2010. cap. 4, p. 1-82

HANISIAN, K.; FORD, R. Design Impact. Cincinatti, 2008. Disponível em:<http://www.dimpact.org/\#mission>. Acesso em: 04 jul. 2013.

HARVEY, D. Condição Pós-Moderna: uma pesquisa sobre as origens da Mudança Cultural. 2 ed. São Paulo: Edições Loyola, 2012. p.26

HENG, L. C. Caracterização da Gestão de Desenvolvimento do Produto: Delineando o seu Contorno e Dimensões Básicas. In: Anais do II Congresso Brasileiro de Gestão de Desenvolvimento de Produto. São Carlos: 2000. p. 1-9. Disponível em: <http://www.dep.ufmg.br/old/disciplinas/epd034/artigo2.pdf>. Acesso em: 19 ago. 2015.

KÜHNLE, H. Distributed Manufacturing: Paradigm, Concepts, Solutions and Examples. Stuttgart: Springer, 2010.

IBGE - INSTITUTO BRASILEIRO DE GEOGRAFIA E ESTATISTICA (IBGE). CIDADES@. IN: Rio Grande do Sul, Novo Hamburgo, Estimativa da população 2015. Disponível em: <http://cidades.ibge.gov.br/xtras/perfil.php?lang=\&codmun=431340\&search $=\|$ infogr\%E1ficos :-informa\%E7\%F5es-completas $>$. Acesso em 03 set.2015.

IBGE - INSTITUTO BRASILEIRO DE GEOGRAFIA E ESTATISTICA (IBGE). CIDADES@ . IN: Rio Grande do Sul, Novo Hamburgo, Informações Completas, 2010. Disponível em: <http://cidades.ibge.gov.br/xtras/perfil.php?lang=\&codmun=431340\&search=\|infogr\%E1 ficos :-informa\%E7\%F5es-completas>. Acesso em 03 set.2015.

IEIS, F. et al. Sistema Nacional de Inovação: Relações de Cooperação para Inovar nas Empresas Privadas e Estatais Brasileiras. Venezuela: Ed. Spacios. Vol. 34, nº. 7, p. 5, 2013. Disponível em: <http://www.revistaespacios.com/a13v34n07/13340705.html> Acesso em: 04 set.2015.

INSTITUTO CIDADANIA. Projeto Política Nacional de Apoio ao Desenvolvimento Local. Documento de conclusão versão inicial para discussão, complementação e ajustes. Set. 2006. Disponível em: <http://www.polis.org.br/uploads/1509/1509.pdf>. Acesso em: 23 mar. 2015.

IPEA - INSTITUTO DE PESQUISA ECONÔMICA APLICADA. Número de indivíduos pobres Linha de Pobreza Baseada em Necessidades Calóricas. In: IPEADATA, Social, Renda. Brasília: 2013. Disponível em: 〈http://www.ipeadata.gov.br/>. Acesso em: 09 ago. 2015.

IPEA - INSTITUTO DE PESQUISA ECONÔMICA APLICADA. Uma Proposta de Erradicação da Extrema Pobreza Urbana via Inclusão Produtiva. In: Relatório de Pesquisa. Rio de Janeiro: IPEA, 2013. p. 7.

ITS - INSTITUTO DE TECNOLOGIA SOCIAL. Tecnologia Social. Instituto de Tecnologia Social: série "Conhecimento e Cidadania I". p. 15-19. São Paulo: ITS, 2007. Disponível em: < http://www.itsbrasil.org.br/sites/itsbrasil.w20.com.br/files/Digite_o_texto/Caderno_Serie_Conheci mento_e_Cidadania_-_Tecnologia_social_-_1.pdf>. Acesso em 12 mar. 2012.

INEP - INSTITUTO NACIONAL DE ESTUDOS E PESQUISAS DUCACIONAIS ANÍSIO TEIXEIRA. Data escola Brasil. 2015. Disponível em: <http://www.dataescolabrasil.inep.gov.br/dataEscolaBrasil/home.seam>. Acesso em: 16 set. 2015. 
INEP - INSTITUTO NACIONAL DE ESTUDOS E PESQUISAS EDUCACIONAIS ANÍSIO TEIXEIRA. Dados finais do Censo Escolar da Educação Básica de 2014 - Apêndice I. In: Censo Escolar. 2014. Disponível em: < http://portal.inep.gov.br/basica-censo>. Acesso em: 27 mai. 2015.

JORNAL ZERO HORA. Brechó na Escola: feiras de uniformes escolares usados aliviam o bolso dos pais no início do ano letivo. Caderno Meu Filho. Porto Alegre: 2013. Disponível em: $<$ http://zerohora.clicrbs.com.br/rs/vida-e-estilo/bem-estar/noticia/2013/03/feiras-de-uniformesescolares-usados-aliviam-o-bolso-dos-pais-no-inicio-do-ano-letivo-4070592.html>. Acesso em 28 jun. 2013.

"KANDACHAR. P. et al. Emergin Designing wigth Markets: Design of Products and Services. Holanda: Delft University, 2011. Disponível em: <http://www.io.tudelft.nl/fileadmin/Faculteit/IO/Actueel/Congressen_en_symposia/2012/Beyond_ design/TUDELFT_BOP_CROP_S.pdf> acessado em 10 mar. 2014.

KAY J., Foundations of corporate success: how business strategies add value. Oxford: Oxford University Press, 1993

KELLER, P.; LIMA, R. G. Artesanato em debate, Pós Ciências Sociais, v.8, n.15, jan./jun. 2011. Disponível em:

<http://www.periodicoseletronicos.ufma.br/index.php/rpcsoc/article/viewFile/593/339>. Acesso em: 20 set.2015.

KRUCKEN, L. Design e Território: valorização de Identidades e Produtos Locais. Studio Nobel, 2009. p. 17;32.

LASTRES, H. M. M.; CASSIOLATO, J. E. Glossário de Arranjos e Sistemas Produtivos e Inovativos Locais. In: arranjos produtivos locais: uma nova estratégia de ação para o sebrae. REDESIST, 2003. p. 3-4. Disponível em: < http://portalapl.ibict.br/export/sites/apl/galerias/arquivos_noticias/glossario.pdf >. Acesso em: 05 set. 2015.

LEIS, F. et al. Sistema Nacional de Inovação: Relações de Cooperação para Inovar nas Empresas Privadas e Estatais Brasileiras. v. 34(7) Venezuela: Spacios, 2013, p. 5. Disponível em:< http://www.revistaespacios.com/a13v34n07/13340705.html> Acesso em: 04 set.2015.

LEROI - GOURHAN, A. Os Caçadores da Pré - História. 70 ed. 2007. p. 113

LOBACH, B. Design Industrial: Bases para a configuração dos produtos industriais. São Paulo: Edgard Blucher, 2001. p. 54

LOBATO, M. Urupês. 37 ed. Revisada. São Paulo: Brasiliense, 1994. (4ª reimpressão 1998).

MACHADO, C. J. S. As relações entre tecnologia, inovação e sociedade. Ciência da Informação, v.7, n.1, 2006. Disponível em: <http://www.dgz.org.br/fev06/Art_02.htm>. Acesso em: 05 out.2015.

MACIEL, M. L.; ALBAGLI, S. Conhecimento e aprendizado por interação: notas metodológicas para estudos empíricos em APLs. In: ARRANJOS PRODUTIVOS LOCAIS: UMA NOVA ESTRATÉGIA DE AÇÃO PARA O SEBRAE - Conhecimento e Aprendizado por Interação. p. 2-5. Rio de Janeiro: REDESIST e SEBRAE, 2002. Disponível em: <http://www.ie.ufrj.br/redesist/piloto/Textos/aprendizado.PDF>. Acesso em 05 set. 2015.

MANZINI, E. Design para a inovação social e sustentabilidade. Caderno do Grupo de Altos Estudos. v. 1 Rio de Janeiro: Programa de Engenharia de Produção da Coppe/UFRJ, 2008.

MARGOLIN, V.; MARGOLIN, S. A "Social Model” of Design: Issues of Practice and Research. In: Design Issues: Massachusetts Institute of Technology, v 18, n. 4 , 2002. Disponível em: $<$ http://www.dis.uia.mx/profesores/juanfdonoso/spring2010/dint8/descargas/SocialModelofDesign .pdf>. Acesso em:

MARTINS, S. Contribuição ao Estudo Científico do Artesanato. Belo Horizonte: Imprensa Oficial do Estado de Minas Gerais, 1973.

MATOS, M. G. P. Arranjos Produtivos Locais de base cultural e desenvolvimento: determinantes de competitividade e sustentabilidade. Rio de Janeiro, 2013 Disponível em:< 
http://www.redesist.ie.ufrj.br/lalics/papers/85_Arranjos_Produtivos_Locais_de_base_cultural_e_d esenvolvimento_determinantes_de_competitividade_e_sustentabilidade.pdf $>$. Acesso em:

MAYER, G. W.; BORGES, J. R. Canteiros produtivos e terreiros de raspa de mandioca. Bahia: Banco de Tecnologias Sociais da Funcação Banco do Brasil, 2013. Disponível em: < http://www.fbb.org.br/tecnologiasocial/banco-de-tecnologias-sociais/pesquisartecnologias/detalhar-tecnologia-68.htm>. Acesso em: 08 jul. 2015.

MELO, J. J. BANCO PALMAS ... um caminho. n. 29. Brasília: Banco Centro do Brasil, In: Boletim Responsabilidade Social e Ambiental do Sistema Financeiro, Ano 3, 2008. Disponível em: < https://www.bcb.gov.br/pre/boletimrsa/BOLRSA200804.pdf>. Acesso em: 15 out.2015.

MENDONÇA, H. Comércio justo e economia solidária no brasil e o papel da política pública na sua promoção. n. 49 Brasília: IPEA, Mercado de trabalho, 2011. Disponível em:< http://repositorio.ipea.gov.br/bitstream/11058/3934/1/bmt49_econ01_comerciojusto.pdf > Acesso em: 09 set.2015.

MERONI, A. Estrategic design: where are we now? Reflection around the foundations of a recent discipline, SDRJ (Strategic design research journal ), v. 1, n. 1, 2008. Disponível em: <http://revistas.unisinos.br/index.php/sdrj/article/view/5567>. Acesso em:

MINISTÉRIO DA CIÊNCIA, TECNOLOGIA E INOVAÇÃO. Estratégia Nacional de Ciência, Tecnologia e Inovação 2012 - 2015. Brasília: MCTI, 2012. p. 220. Disponível em:<http://www.mct.gov.br/upd_blob/0218/218981.pdf> Acesso em: 09 out. 2015.

. Estratégia Nacional de Ciência, Tecnologia e Inovação 2012 - 2015. Brasília: MCTI, 2012. p. 220. Disponível em:〈http://www.mct.gov.br/upd_blob/0218/218981.pdf>. Acesso em: 09 out. 2015.

. Plano de Ação em Ciência, Tecnologia e Inovação Principais Resultados e Avanços 2007 - 2010. Brasília: MCT, 2010. p. 18 Disponível em:〈http://www.mct.gov.br/upd_blob/0214/214525.pdf>. Acesso em: 03 out. 2015.

MINISTÉRIO DA SAÚDE. Política Nacional de Atenção Básica. Brasília, DF: Ministério da Saúde, 2012. p. 9-10-43. Disponível em: <http://189.28.128.100/dab/docs/publicacoes/geral/pnab.pdf> acesso em: 12 out. 2015.

. Política Nacional de Educação Popular em Saúde [Pneps]. Brasília: COMITÊ NACIONAL DE EDUCAÇÃO POPULAR EM SAÚDE - CNEPS, 2012. Disponível em: <http://www.crpsp.org.br/diverpsi/arquivos/PNEPS-2012.PDF>. Acesso em: 12 set. 2015.

MINISTÉRIO DO DESENVOLVIMENTO SOCIAL (MDS). Bolsa Família complementa renda de 14 milhões de famílias em janeiro. In: Sala de Imprensa, Notícias, 2015. Disponível em: < http://www.brasil.gov.br/cidadania-e-justica/2015/01/bolsa-familia-complementa-renda-de-14-mide-familias-em-janeiro>. Acesso em: 14 ago. 2015.

. Bolsa Família: quase $96 \%$ dos estudantes acompanhados cumpriram frequência escolar. In: Sala de Imprensa, Notícias, 2014. Disponível em: <http://mds.gov.br/area-deimprensa/noticias/2014/julho/bolsa-familia-96-4-dos-alunos-acompanhados-cumpriramfrequencia-exigida>. Acesso em: 04 ago. 2015.

MINISTÉRIO DO TRABALHO. Norma Regulamentadora ${ }^{\circ}$. 1. In: Legislação, Normas Regulamentadoras: Alteração dada pela Portaria n. ${ }^{\circ}$ 06, de 09/03/83. Brasília: 1983. Disponível em: <http://acesso.mte.gov.br/legislacao/normas-regulamentadoras-1.htm>. Acesso em: 19 ago. 2015.

MORAES, D. Limites do design, Editora Estúdio Nobel, 3 ed. revisada e ampliada, 2008. p. 80-82

MOULAERT, F. et al. Introduction: Social Innovation and Governance in European Cities. European Urban and Regional Studies, v. 14(3), p. 195-209, 2007. Disponível em:<http://dx.doi.org/10.1177/0969776407077737>. Acesso em: 08 out. 2015.

MULGAN, G. et al. Social silicon valleys - a manifesto for social innovation. London: The Young Foundation. 2006. Disponível em: <http://www.anobium.es/docs/gc_fichas/doc/5IMOVYfjkw.pdf>. Acesso em: 08 out. 2015. 
MULGAN, G.; TUCKER, S.; SANDERS, B. Social Innovation: What It Is, Why It Matters and How It Can Be Accelerated. London: The Young Foundation, 2007. Disponível em:< www.youngfoundation.org>. Acesso em: 08 set. 2015.

MURRAY, R.; CAULIER-GRICE, J.; MULGAN, G. The Open Book of Social Innovation. London: The Young Foundation, 2010. Disponível em: < www.nesta.org.uk/publications/assets/features/the_open_book_of_social_innovation>. Acesso em: 18 jun. 2015.

NASCIMENTO, E. P.; COSTA, H. A. DÁDIVA E ARRANJOS PRODUTIVOS LOCAIS: uma abordagem ampliada da cooperação entre empresários. v. 1, n. 17. Pernambuco: PPGS - Revista do Programa de Pós-Graduação em Sociologia da UFPE, 2011. Disponível em:< http://www.revista.ufpe.br/revsocio/index.php/revista/article/view/51/41> Acesso em: 13 out.2015.

NAVARRO, V.L. Trabalho e trabalhadores do calçado. São Paulo: Expressão Popular, 2006. p. 304

NERI, M. Extrema pobreza reduz 63,3\% nos últimos dez anos. Instituto de Pesquisa Econômica Aplicada (Ipea). Brasília: 2013. Disponível em:<

http://www.mds.gov.br/saladeimprensa/noticias/2013/outubro/extrema-pobreza-reduz-63-3-nosultimos-dez-anos> Acesso em: 12 fev. 2014.

NICOLAU, G. H. Brasil criativo \# artesanato. Brasilia: Ministério da Cultura: Secretaria de Políticas Culturais Diretoria de Cultura, Desenvolvimento e Inovação, 2015. Disponível em: <http://www19.senado.gov.br/sdleg-getter/public/getDocument?docverid=eb1de6d5-32c5-4127a363-c86ca43041f4;1.0> Acesso em: 11 AGO.2015.

OBSERVATÓRIO BRASILEIRO DE ARRANJOS PRODUTIVOS LOCAIS. Conheça os APLs: mapa de busca dos APLs brasileiros. In: APLs. OBAPL, 2015. Disponível em:

<http://portalapl.ibict.br/apls/index.html>. Acesso em: 13 ago. 2015.

OBSERVATÓRIO DE ARRANJOS PRODUTIVOS LOCAIS. Lista completa dos APL's do Brasil. In: Biblioteca. GT APL, 2014. Disponível em: <http://portalapl.ibict.br/biblioteca/Lista_de_APLs_do_Brasil_-_2014.html>. Acesso em: 20 ago. 2015 .

OCDE- Organização para Cooperação e Desenvolvimento Econômico. Manual de Oslo: Propostas de diretrizes para coleta e Interpretação de Dados sobre Inovação Técnológica. OCDE, 1997. p. 21. Disponível em: <http://download.finep.gov.br/imprensa/manual_de_oslo.pdf>. Acesso em:

ORGANIZAÇÃO DAS NAÇÕES UNIDAS. Declaração Universal dos Direitos Humanos, Artigo XXV, 1948; Adotada e proclamada pela resolução 217 A (III) da Assembléia Geral das Nações Unidas em 10 de dezembro de 1948. Brasília: UNESCO no Brasil, 1998. Disponível em:<D205http://unesdoc.unesco.org/images/0013/001394/139423por.pdf>. Acesso em: 10 ago. 2015.

ORLOVICIN, N. V.; SUZIGAN, W. Sistemas Locais de Produção na Indústria Brasileira de Calçados: Diagnóstico e Avaliação. In: Projeto de Pesquisa. UNICAMP: Instituto de Economia, 2005. Disponível em: <

http://geein.fclar.unesp.br/arquivos/cluster/ic/arquivos/projeto_pibic_natalia.pdf>. Acesso em 05 jun. 2015.

OTTERLOO, A. M. C. A tecnologia a serviço da inclusão social e como política Pública. In: Tecnologia Social e Desenvolvimento Sustentável: Contribuições da RTS para a formulação de uma Política de Estado de Ciência, Tecnologia e Inovação. Secretaria Executiva da Rede de Tecnologia Social (RTS). Brasília: 2010. p. 17. Disponível em:〈http://www.rts.org.br/bibliotecarts/livros/tecsocialdessust.pdf>. Acesso em: 06 jul. 2013.

PACHECO, H.S. O design e o aprendizado [recurso eletrônico]: barraca: quando o design social deságua no desenho coletivo. Rio de Janeiro, 1996. Originalmente apresentada como Dissertação de mestrado, Pontifícia Universidade Católica do Rio de Janeiro, Departamento de Artes, 107f. Disponível em: 〈http://www.dbd.puc-rio.br/pergamum/biblioteca_s/php/login_tese.php>. Acessado em: 20 fev. 2014. 
PARADIZO, R. J. S. Cooperação para o aprendizado inovativo no Arranjo Produtivo Local de confecções em Campina Grande: Dissertação de Mestrado em Economia - Centro de Ciência Sociais Aplicadas/ Universidade Federal da Paraíba. Paraíba: 2005. p. 114

PNUD BRASIL. Negócios inclusivos apresentam dificuldades para desenvolver seus modelos, mas estratégias específicas ajudam a superar entraves. In: MERCADOS INCLUSIVOS NO BRASIL: desafios e oportunidades do ecossistema de negócios. p. 14-15 Brasília: PNUD BRASIL, DOM CABRAL, 2015. Disponível em:<http://www.iniciativaincluir.org.br/Public/upload/ckfinder/files/PNUD_Mercados\%20Inclusi vos\%20no\%20Brasil_Desafios\%20e\%20oportunidades.pdf >. Acesso em 05.10.2015.

PORTER, M. E. A vantagem competitiva das nações. Rio de Janeiro: Campus, 1989.

PRAHALAD, C.K.; HART, S. The fortune at the bottom of the pyramid. Strategy + Business, n. 26, 2002. Disponível em: 〈http://www.cs.berkeley.edu/ brewer/ict4b/Fortune-BoP.pdf〉. Acesso em: 07 ago. 2013.

PROGRAMA DAS NAÇÕES UNIDAS PARA O DESENVOLVIMENTO. Ranking IDHM Municípios 2010. In: Atlas do Desenvolvimento Humano no Brasil, 2013. Disponível em:<http://www.pnud.org.br/atlas/ranking/ranking-idhm-municipios-2010.aspx>. Acesso em: 04 ago. 2015.

PUGH, S. Total Design: integrated Methods for Successful Product Engineering. Wokingham: Addison Wesley. 1990

REDE DE TECNOLOGIA SOCIAL. Documento Constitutivo Da Rede De Tecnologia Social. Brasília: 2005. Disponível em:< http://rts.ibict.br/a-rts/documentoconstitutivo/documento_constitutivo.pdf $>$. Acesso em: 03 ago. 2015.

REDESIST - Rede de Pesquisa em Sistemas Produtivos e Inovativos Locais. Glossário de Arranjos e Sistemas Produtivos e Inovativos Locais. In: arranjos produtivos locais: uma nova estratégia de ação para o SEBRAE, 2003. Disponível em: <http://portalapl.ibict.br/export/sites/apl/galerias/arquivos_noticias/glossario.pdf>. Acesso em: 08. Jun. 2015.

REDIG, J. Design: responsabilidade social no horário do expediente. In: O papel social do design gráfico. História, conceitos \& atuação profissional. 1 ed. São Paulo: Senac, 2011. p. 93

Redig, J. Design: responsabilidade social no horário do expediente. In: O papel social do design gráfico. História, conceitos \& atuação profissional. 1 ed. São Paulo: Senac. 2011.

REINHARDT , A. Steve jobs: there's sanity returning. In: Business week, Q\&A, 25 mai. 1998. Disponível em:< http://www.businessweek.com/1998/21/b3579165.htm>. Acesso em: 09 out. 2015.

REINHARDT , A. Steve jobs: there's sanity returning. In: Business week. Q\&A, 25 mai. 1998. Disponível em:< http://www.businessweek.com/1998/21/b3579165.htm>. Acesso em: 09 out. 2015.

RIBEIRO, D. Apresentação do Livro A Tecnologia da Tecnologia 1983. In: BONSIEPE, G. Design como prática de projeto. p. 9-12. São Paulo: Blucher, 2012.

Rodrigues, I.; Barbieri, J. C. A emergência da tecnologia social: revisitando o movimento da tecnologia apropriada como estratégia de desenvolvimento sustentável. Rio de Janeiro: Rap, 2006. Disponível em: <http://www.scielo.br/pdf/rap/v42n6/03.pdf>. Acesso em 21 out. 2013

ROOZENBURG, N. F. M.; EEKELS, J. Product Design: Fundamentals and Methods. Utrecht: Lemma, 1995

ROZAS, G. Pobreza y desarrollo local. In: Excerpta. n. 7. Universidade do Chile: Faculdad de Ciencias Sociales, 1998. Disponível em:

<http://www.facso.uchile.cl/publicaciones/biblioteca/docs/excerpta/excerpta7.pdf>. Acesso em: 23 mai. 2015

ROZENFELD, H. et al. Gestão de desenvolvimento de produtos: uma referência para melhoria do processo. São Paulo: Saraiva, 2006.

SACHS, I. Desenvolvimento Includente, Sustentável, Sustentado. Rio de Janeiro: Garammond \& SEBRAE, 2004. p. 38. 
SAE - Secretaria de Assuntos Estratégicos. Vozes da Classe Média: é ouvindo a população que se constroem políticas públicas adequadas. Brasília: Ed. Presidência da República, edição Marco Zero, p. 13-14, 2012. Disponível em:< http://www.sae.gov.br/wp-content/uploads/Cartilha-VozesClasse-Media.pdf> Acesso em: 20 dez. 2015.

Assuntos estratégicos social e renda: a classe média brasileira. Brasília: Ed. Presidência da República, no. 1, 2015. Disponível em:< http://www.sae.gov.br/wpcontent/uploads/ebook_ClasseMedia1.pdf> Acesso em: 20 dez. 2015.

SANTOS, F. M. A Positive Theory of Social Entrepreneurship. In: INSEAD Working Paper Series. França, Fontainebleau: INSEAD, 2009. Disponível em: <https://www.insead.edu/facultyresearch/centres/social_entrepreneurship/research_resources/docu ments/2009-23.pdf>. Acesso em: 21 set. 2015.

SANTOS, M. Por uma outra globalização: do pensamento único à consciência universal. Rio de Janeiro: Record, 2000. p. 53-57. Disponível

em:<http://www.educadores.diaadia.pr.gov.br/arquivos/File/2010/sugestao_leitura/sociologia/outr a_globalizacao.pdf> Acesso em: 10 out. 2015.

SANTOS, R. F. Investigação do método de desenvolvimento de calçados no pólo calçadista do Vale do Rio dos Sinos e Paranhana, no Estado do Rio Grande do Sul. Dissertação de Mestrado em Engenharia da Produção. Programa de Pós-Graduação em Engenharia de Produção, Universidade Federal do Rio Grande do Sul. Porto Alegre: 2008.

SEBRAE - SERVIÇO BRASILEIRO DE APOIO À MICRO E PEQUENAS EMPRESAS. Governança e cooperação. In: Reunião Plenária do GTP-APL. Brasília: SEBRAE, 2010. Disponível:

$<$ http://portalapl.ibict.br/export/sites/apl/menu/itens_menu/gtp_apl/reunioes/links/EIXO_GOVER NANxA_E_COOPERAxO_xSEBRAE_DNx.pdf>. Acesso em: 10 set. 2015.

SEN, A. Desenvolvimento como liberdade. São Paulo: Cia. das Letras, 2000. Disponível em: 〈http://www.companhiadasletras.com.br/trechos/80156.pdf〉. Acesso em: 18 jan. 2015.

SENHORAS, E. M. As redes do desenvolvimento econômico e social no sistema de ensino superior brasileiro, Liinc em Revista. v.4, n.1, p.138-153. Rio de Janeiro, mar. 2008. Disponível em: 〈http://www.ibict.br/liinc>. Acesso em: 15 ago.2015

SEURING, S.; MÜLLER, M. Core issues in sustainable supply chain management - a Delphi Study. Business Strategy and the Environment. V. 17, 2008(a). p. 455-66

SEURING, S.; MÜLLER, M. From a literature review to a conceptual framework for sustainable supply chain management. Journal of Clean Production, v. 16, 2008 (b), p. 1699-1710

SILVA, C. H. Território: Uma Combinação De Enfoques: Material, Simbólico E Espaço De Ação Social. In: Revista Geografar. v. 4, n.1, p. 98-115, jan/jun. Curitiba: 2009. Disponível em: <http://ojs.c3sl.ufpr.br/ojs/index.php/geografar/article/view/14430/9698>. Acesso em: 04 jun. 2015.

SLACK, N.; CHAMBERS, S.; JOHNSTON, R. Administração da produção. 2 ed. São Paulo: Atlas, 2002.

SMITH, A. The International Development Design Summit. MIT, 2007. Disponível em:< http://iddsummit.org/about?sub=2007>. Acesso em: 20 mai.2012.

SUZIGAN, W. et al. Sistemas Locais de Produção: mapeamento, tipologia e sugestões de políticas. In: Pesquisa Cnpq, pesquisa, Processo 466034/2000-8, 2003. Disponivel em:<http://www.anpec.org.br/encontro2003/artigos/E28.pdf> Acesso em: 06 jun. 2015.

THIOLLENT, M. Metodologia da Pesquisa-Ação. 18 ed. Cortez, 2011.

TiCE, D. d.light S2: The Learning Light. In: D-Light Company, 2013. Disponível em: $<$ http://www.dlight.com/solar-lighting-products/single-function/dlight-s2/\#section-tabOverview>. Acesso em: 05.09.2014.

TUBINO, D. F. Planejamento e controle da produção: teoria e prática. São Paulo: Atlas, 2007. p. 1- 5- 51 . 
União Nacional dos Dirigentes Municipais de Educação (Undime). Governo cancela pregão do uniforme escolar. In: Notícias. Brasília: 2003. Disponível em:

$<$ http://undime.org.br/noticia/governo-cancela-pregao-do-uniforme-escolar>. Acesso em: 15 out. 2015.

UNITED NATIONS. The Millennium Development Goals Report 2015. New York: UNO, 2015. Disponível em:

<http://mdgs.un.org/unsd/mdg/Resources/Static/Products/Progress2015/English2015.pdf>. Acesso em: 05 set. 2015 .

VIDIGAL, M. Ricardo Lima, um antropólogo de mãos dadas com o artesanato. In: ENCONTROS. São Paulo: A CASA, 2003. Disponível em: 〈http://www.acasa.org.br/biblioteca/texto/45>. Acesso em: 04 nov. 2014.

VIEIRA, E. T. Industrialização e Políticas de Desenvolvimento Regional: o Vale do Paraíba paulista na segunda metade do século XX. Tese de Doutorado em Historia Econômica, Universidade de São Paulo. p. 19. São Paulo: 2009. Disponível em: <http://www.teses.usp.br/teses/disponiveis/8/8137/tde-03022010-143611/pt-br.php>. Acesso em: 25 set. 2015

VULCABRÁS, A. Processo Produtivo. In: A Empresa. 2015. Disponível em: $<$ http://vulcabrasazaleiari.com.br/a-empresa/processo-produtivo/>. Acesso em: 18 ago. 2015.

WANG, L.; SHEN, W. An Effective Approach for distributed process planning enabled by eventdriven function blocks. In: Process Planning and Scheduling for Distributed Manufacturing. Londres: Spring, 2007. p. 5-6

ZURLO, F. Design Strategico. In: XXI Secolo, Gli spazi e le arti, v. 4. Roma: Enciclopedia Treccani, 2010. Disponível em: $<$ http://www.treccani.it/enciclopedia/designstrategico_(XXI_Secolo)/>.Acesso em: 30 de abri. 2014. 


\title{
ANEXOS
}

\section{1. \\ ANEXO I - Email do Diretor da Secretaria de Tecnologia e Inclusão, do Ministério da Ciência e Tecnologia, durante entrevista para esta pesquisadora}

\author{
De: Diretor da Secretaria de Tecnologia e Inclusão do MCT 26/02/2014
}

\author{
Para: ronises@hotmail.com
}

\section{Prezada Rosine}

A tecnologia social compreende produtos, técnicas ou metodologias, reaplicáveis, desenvolvidas na interação com a comunidade e que representam efetivas soluções de transformação social.A Tecnologia Social abrange temas e áreas voltadas especificamente para a identificação e solução de demandas sociais locais, para as quais as tecnologias não se mostram adequadas ou acessíveis. $\mathrm{O}$ acesso da população às tecnologias sociais é favorecido por meio de projetos de extensão, de desenvolvimento, de reaplicação e de capacitação em tecnologia social, bem como pela fomento a instituições de pesquisa, entidades da administração pública direta e indireta e de organizações sociais sem fins lucrativos com comprovada experiência na área.

As primeiras discussões em torno do que hoje convencionou chamar de Tecnologia Social como proposta de política pública começaram em julho de 2004 a partir dos debates sobre extensão tecnológica, tecnologias apropriadas e da abordagem crítica em torno das tecnologias convencionais e do processo de exclusão social associado a estas.

Em agosto de 2004 foram formados Grupos de Trabalho, responsáveis pelo aprofundamento dos debates e pela construção dos conceitos e a estruturação de uma rede de instituições públicas e privadas ligadas ao tema da tecnologia social. Em novembro de 2004 foi realizada na cidade de São Paulo a $1^{\text {a }}$ Conferência Internacional e Mostra de Tecnologia Social.

As reuniões com os primeiros interessados em participar do debate, principalmente universidades e instituições do terceiro setor, proporcionou um avanço na compreensão do tema e contribuiu para o início das discussões sobre a tecnologia social.

A SECIS, desde então, participa ativamente do desenvolvimento da Tecnologia Social como solução efetiva da transformação social, com foco na resolução dos problemas sociais enfrentados por populações sem acesso aos recursos tecnológicos convencionais.

Ainda em 2004 a SECIS apoiou projetos por meio dos seguintes editais conjuntos: Edital MCT/MDA/EMBRAPA 2004 - Disponibilização e apropriação de tecnologias para agricultores familiares brasileiros, resultando em 70 projetos aprovados. Edital CT-AGRO/MCT/MDA/CNPq 22/2004 - Apoio a projetos de tecnologias apropriadas à agricultura familiar, com 99 projetos aprovados.

Em abril de 2005, a Rede de Tecnologia Social foi formalmente criada, composta por entidades públicas e privadas com o objetivo de reunir e organizar um conjunto de instituições com o propósito de promover o desenvolvimento sustentável mediante a difusão e a reaplicação em escala de tecnologias sociais. Entre os objetivos da RTS destacam-se: 1) a adoção de tecnologias sociais como Políticas Públicas e 2) a apropriação pelas comunidades-alvo das tecnologias sociais reaplicadas.

Ainda neste ano foram lançados os seguintes editais na área de Tecnologia Social: Edital MCT/CNPq $n^{\circ}$ 18/2005 - Apoio a projetos de tecnologias sociais para inclusão social de catadores de materiais recicláveis, com 35 projetos aprovados. Edital MCT/CNPq n 19/2005 Disponibilização de tecnologias para inclusão social: água, alimentação humana e animal, com 93 projetos aprovados. Edital MCT/CNPq n ${ }^{\circ}$ 20/2005 - Disponibilização de tecnologias de base 
ecológica apropriada à agricultura familiar, com 62 projetos aprovados. Edital MCT/MMA/SEAP/SEPPIR/CNPq no 26/2005 - Apoio a projetos de tecnologias sociais para comunidades tradicionais e indígenas, com 42 projetos aprovados.

Entre 2006 foram realizados articulações com a FINEP, com vistas ao desenvolvimento de um programa de extensão tecnológica voltado para o desenvolvimento social.

Em 2008, o conceito de tecnologia social passa a ser apropriado nas universidades brasileiras, resultando em diversas publicações sobre o tema. Neste foi lançado Edital em parceria com o CNPq e a Secretaria de Aquicultura e Pesca para a seleção de Projetos de Geração e Disponibilização de Tecnologias para a Agricultura Familiar de Base Ecológica, Comunidades Tradicionais e Povos Indígenas, somando um total de 68 propostas aprovadas.

Em 2009, foi lançado em parceria com a FINEP, a Chamada Pública para apoio a Projetos de Tecnologias para o Desenvolvimento Social, com um alinha temática específica para o desenvolvimento de tecnologia social em contextos produtivos de empreendimentos solidários, em territórios urbanos ou rurais, com vistas a contribuir para a redução da pobreza e das desigualdades sociais e para o desenvolvimento territorial sustentável e solidário. Foram aprovados 13 projetos. Ainda este ano foi lançado em parceria com o CNPq Edital para apoio a projetos de Extensão Tecnológico com foco no incremento da produtividade da cadeia de recicláveis, em Tecnologias de Gestão de empreendimentos solidários, na melhoria da condição de trabalho e na segurança alimentar e nutricional dos catadores materiais recicláveis, bem como na produção transformação, comercialização e consumo de produtos orgânicos/ecológicos, somando 78 projetos aprovados.

Em 2010 em, novamente em parceria com o CNPq foi lançado Edital para apoio a projetos de pesquisa na área temática de Segurança Alimentar e Nutricional, com previsão de apoio para linhas de pesquisa em Tecnologia Social para a Segurança Alimentar e Nutricional e para a produção de alimentos orgânicos, somando um total de 30 projetos aprovados.

Em 2011, a SECIS lançou chamamento público para apoio a projetos em Extensão Tecnológica para o Desenvolvimento Social, com uma linha de ação específica para apoio a projetos de Tecnologia Social. Neste chamamento foram aprovados 6 projetos.

Em 2013, em aprceria com o CNPQ e o Ministério do Trabalho foi aberto Chamada Pública para seleção de projetos de pesquisa e extensão de Incubadoras de Empreendimentos Econômicos Solidários. Foram apoiadas 86 propostas.

Objetivos da Ação:

- Apoio a projetos para a pesquisa, desenvolvimento e reaplicação de tecnologias sociais.

- Incentivo a processos de pesquisa participativa e de formação de redes locais e regionais de experimentadores.

- Apoio a empreendimentos econômicos solidários que estejam relacionadas aos processos de inovação ou geração de novos conhecimentos.

- Promoção de alternativas tecnológicas de acesso à água para famílias do semi árido.

- Promoção de alternativas tecnológicas para o fortalecimento dos sistemas produtivos locais, baseado em metodologias participativas e sustentáveis.

- Fortalecimento de núcleos universitários de pesquisa e desenvolvimento em tecnologia social. - Apoio à formação de técnicos, tecnólogos, graduandos, mestres e doutores em tecnologia social. Eu particularmente, à título de exemplificação, recomendo a consulta ao Banco de Tecnologias Sociais da Fundação Banco do Brasil. 
7.2 .

ANEXO II - MATRIZ SQC - SUSTENTABILIDADE, QUALIDADE E CUSTO

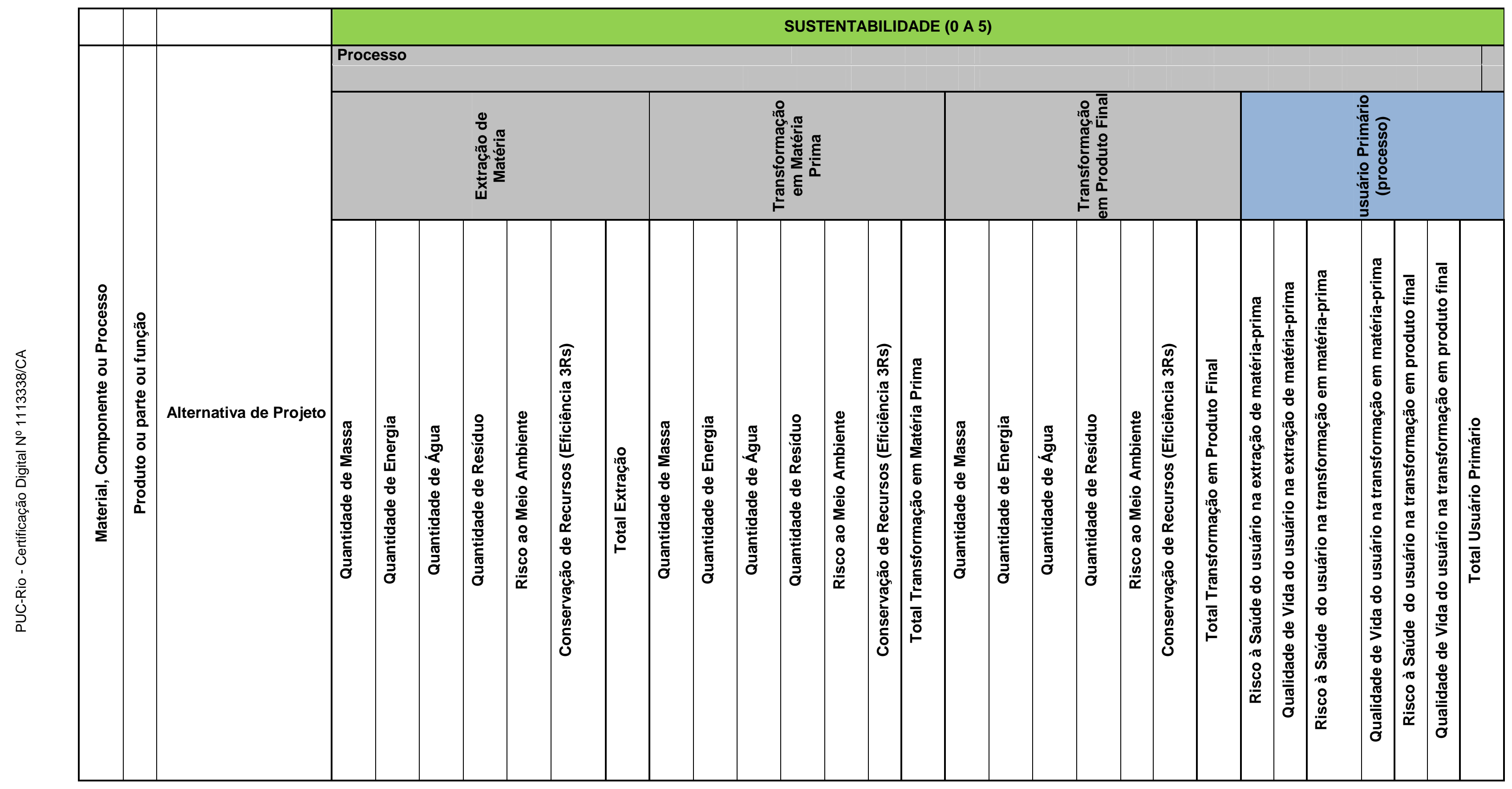




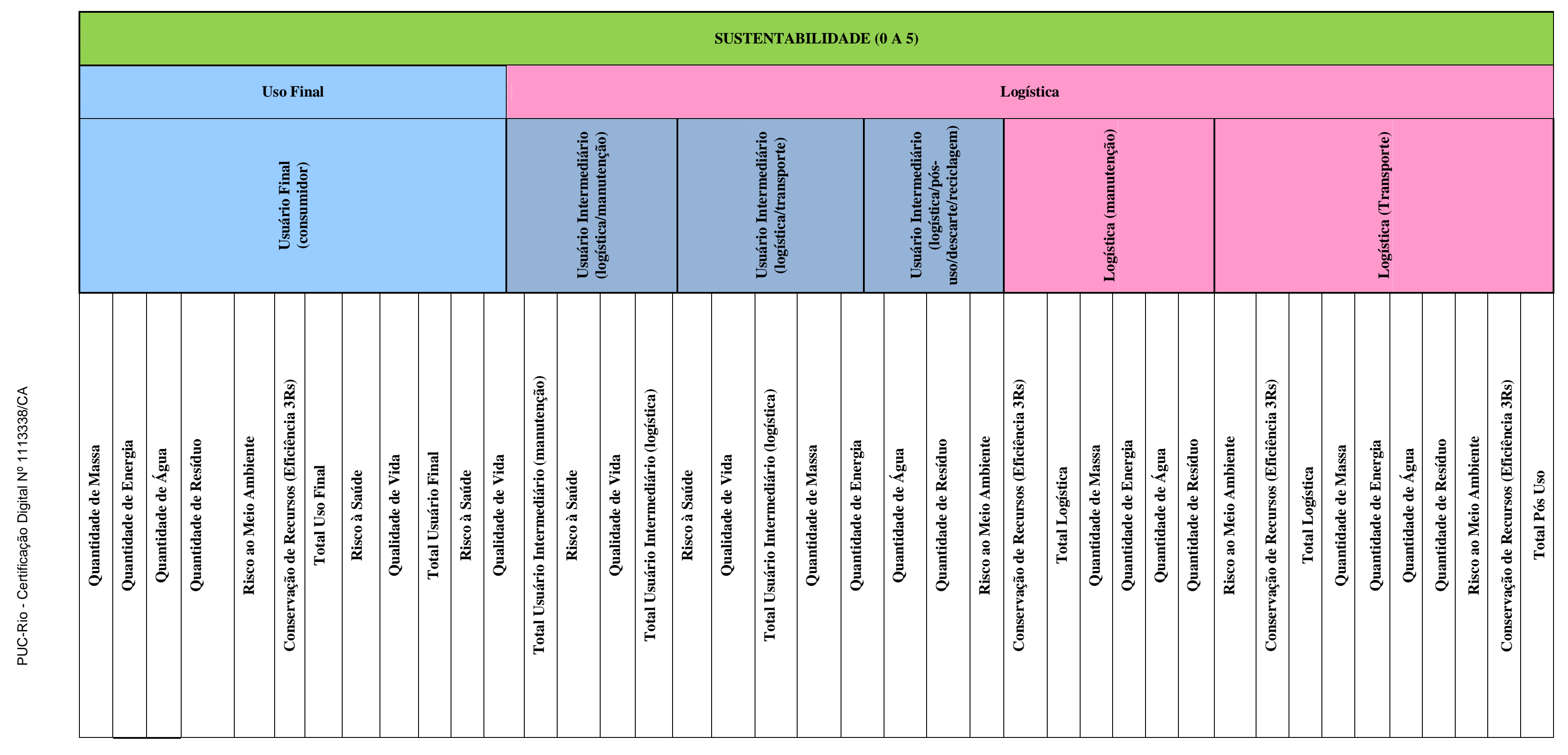




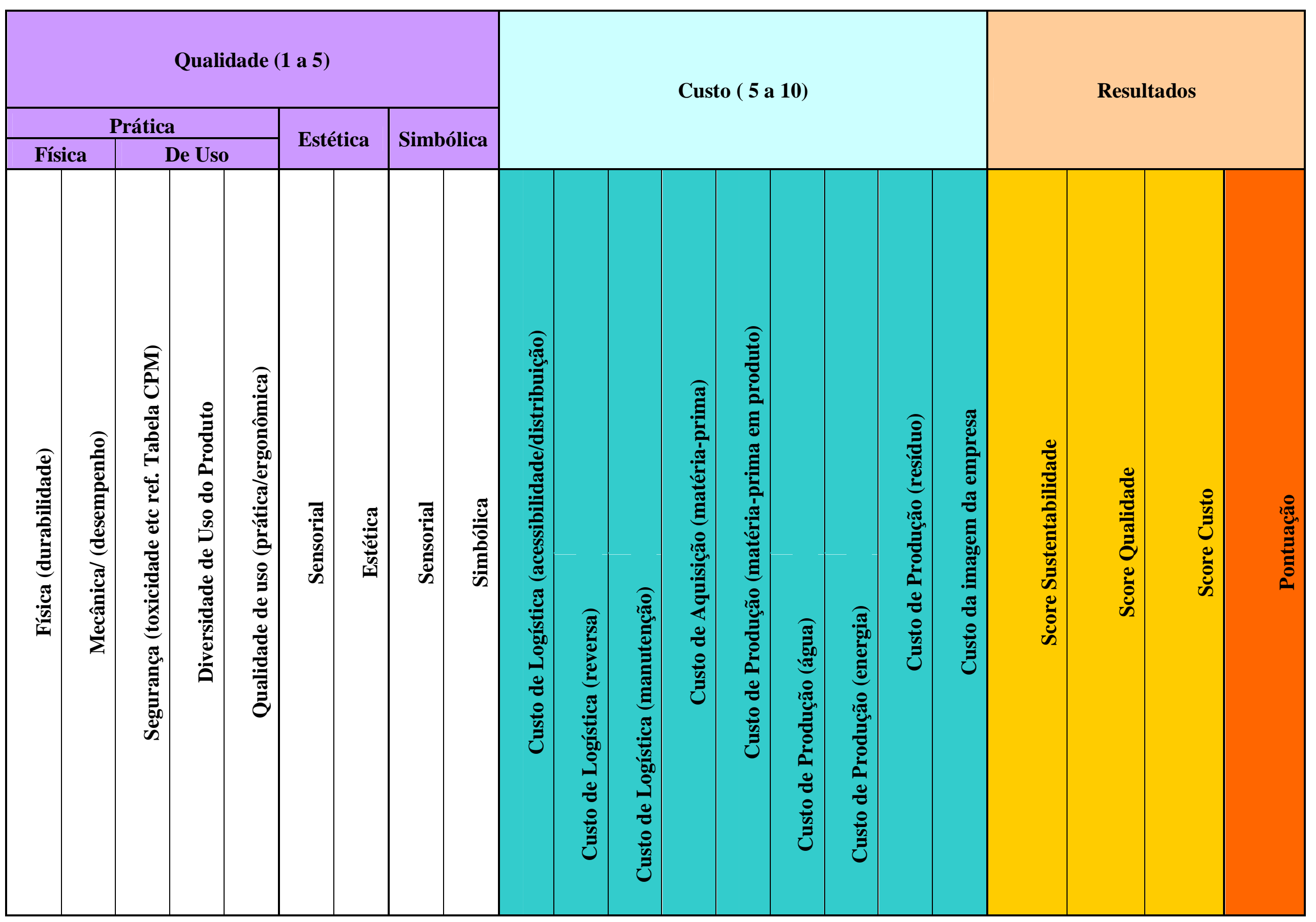




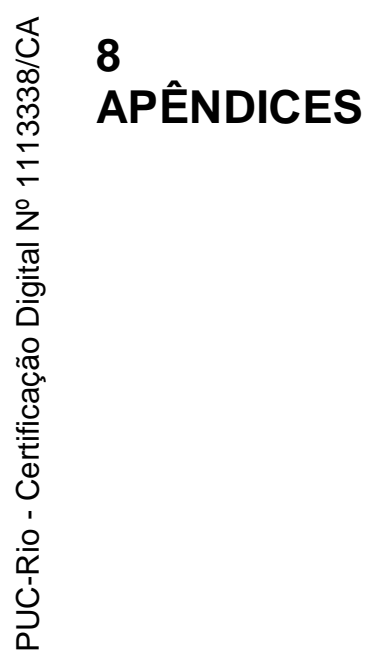


8.1.

APÊNDICE I- Planilha com critérios de análise para as experiências projetuais do Brasil e do Grupo de Delft

Grupo 1 - Dados identificadores / demográficos do projeto

\begin{tabular}{|c|c|c|c|}
\hline $\begin{array}{l}\text { No. total } \\
\text { critérios }\end{array}$ & $\begin{array}{l}\text { No. de } \\
\text { critérios } \\
\text { p/ Grupo }\end{array}$ & Critérios de analise dos projetos & Descrição do critério \\
\hline 1 & 1 & Nome do Projeto; Ano inicial; Local & Dados demográficos do Projeto para melhor identificação \\
\hline 2 & 2 & \begin{tabular}{|l|l} 
Público alvo & \\
\end{tabular} & Identificar se o projeto atendeu populações de baixa renda. \\
\hline 3 & 3 & $\begin{array}{l}\text { Qual a necessidade básica atendida: água, energia, } \\
\text { alimentação, saúde, habitação, lazer, subsistência por } \\
\text { inclusão produtiva ou outro? }\end{array}$ & $\begin{array}{l}\text { De acordo com os direitos humanos todo individuo deve ter suas necessidades básicas } \\
\text { atendidas. E este projeto está considerando a abordagem do design comprometido com } \\
\text { questões sociais de populações de baixa renda como praticas de atendimento os direitos } \\
\text { humanos. Este critério tem impacto nos propósitos projetuais: critério } 3 \text { do Grupo } 6 \text {. }\end{array}$ \\
\hline 5 & 5 & $\begin{array}{l}\text { Houve desenvolvimento de produto? Que tipo de } \\
\text { produto: individual, familiar ou coletivo? }\end{array}$ & $\begin{array}{l}\text { Este critério tem relação com um dos critérios gerais para triagem dos projetos a serem } \\
\text { analisados, descrito no item 1.1.1.4, desde Capítulo Interessa identificar o numero de projetos } \\
\text { que se preocuparam em atender necessidades individuais dos seres humanos, conforme } \\
\text { descrito o item } 1.1 .1 .3 \text { e conforme o estudo de caso desta tese. Pois tal característica } \\
\text { restringe o uso de uma das estratégias de design Sistema-Produto-Servico (SPS) muito } \\
\text { utilizada no planejamento operacional para este tipo de projeto, em relevância aos conceitos de } \\
\text { sustentabilidade. }\end{array}$ \\
\hline 6 & 6 & Quais os atores envolvidos? & $\begin{array}{l}\text { Identificar qual o perfil dos setores de economia }\left(1^{\circ}, 2^{\circ} \text {. ou } 3^{\circ}\right) \text { da rede de cooperação } \\
\text { organizacional que mais se apresenta para operacionalizar este tipo de projeto. }\end{array}$ \\
\hline 7 & 7 & $\begin{array}{l}\text { Quais os profissionais envolvidos ou normalmente } \\
\text { envolvidos (além do designer-pesquisador)? } \\
\text { (antropólogos, sociólogos, assistentes sociais, } \\
\text { engenheiros...). }\end{array}$ & $\begin{array}{l}\text { Identificar o perfil multidisciplinar deste tipo de projeto. E se foram considerados } \\
\text { profissionais como: psicólogos, assistentes sociais, médicos, sociólogos ou antropólogos. }\end{array}$ \\
\hline 8 & 8 & $\begin{array}{l}\text { A partir do campo do design: como o projeto se } \\
\text { auto-define (design social, design comprometido } \\
\text { com questões sociais ou outro)? }\end{array}$ & $\begin{array}{l}\text { Como design social, o termo mais usado conduz a discussão de que todo projeto de } \\
\text { design é destinado à sociedade, apesar da conotação de preocupação com necessidades de } \\
\text { populações de baixa renda dada ao termo. Durante os acessos à literatura foram diversos os } \\
\text { termos encontrados referindo-se a esta prática do design. Caberia então questionar para uma } \\
\text { descrição da nomenclatura, a partir deste trabalho. }\end{array}$ \\
\hline
\end{tabular}


Grupo 2 - Dados do Planejamento estratégicos do projeto

\begin{tabular}{|c|c|c|c|}
\hline $\begin{array}{l}\text { No. total } \\
\text { critérios }\end{array}$ & $\begin{array}{c}\text { No. de } \\
\text { critérios p/ } \\
\text { Grupo }\end{array}$ & Critérios de analise dos projetos & Descrição do critério \\
\hline 9 & 1 & $\begin{array}{l}\text { Qual o foco projetual: negócios, } \\
\text { transformação social, ou outro? Porque? }\end{array}$ & $\begin{array}{l}\text { Este critério define qual o propósito do projeto, se apenas há a entrega de um produto por } \\
\text { venda à população. O que os mantém distante de um processo de desenvolvimento com } \\
\text { liberdade (Sen, 2010). Não os permitem desenvolver suas capacidades de "ser e fazer" por si } \\
\text { mesmos (Robeyns, 2006). Critério que orienta a postura ética do design quando propõe um } \\
\text { projeto desta natureza e define seu foco: negócio, transformação social e outros tipos } \\
\text { organizacionais (Critério } 1 \text { - Grupo 2) }\end{array}$ \\
\hline 10 & 2 & $\begin{array}{l}\text { Qual é a específica necessidade que ele } \\
\text { atende? Sobre o problema. }\end{array}$ & $\begin{array}{l}\text { Este critério está relacionado às necessidades humanas () consideradas como direitos } \\
\text { humanos. Aqueles que são exatamente os direitos correspondentes à dignidade dos seres } \\
\text { humanos, ou seja, são direitos que possuímos pelo simples fato de que somos humanos } \\
\text { (Rabenhorst, 2001). Sendo algumas: água, energia, alimentação, saúde, educação (ONU, 1995; } \\
\text { Artigo 25, pag. 31) }\end{array}$ \\
\hline 11 & 3 & Como tudo começou? & $\begin{array}{l}\text { Ė importante conhecer a historia do projeto desde o início, porque apresenta parte de seus } \\
\text { propósitos e condução de seu desenvolvimento. Se demanda popular, governamental, } \\
\text { autônoma, por entidade não-governamental ou por empresa. }\end{array}$ \\
\hline 12 & 4 & $\begin{array}{l}\text { Sobre o preço do produto cobrado para o } \\
\text { público-alvo? }\end{array}$ & $\begin{array}{l}\text { Este critério vai de encontro ao critério no } 1 \text { (deste Grupo) em relação ao foco do negócio. } \\
\text { A proposta é de valores acessíveis que possui como renda menos que } 1 \$ \text { por dia. }\end{array}$ \\
\hline 13 & 5 & $\begin{array}{l}\text { Há prioridade para que a origem } \\
\text { dos insumos/ componentes seja } \\
\text { local? }\end{array}$ & $\begin{array}{l}\text { Este critério depende do foco projetual. Define se o projeto tem interesse no } \\
\text { desenvolvimento humano e local. Se há interesse em melhorias da qualidade vida da } \\
\text { população-alvolocal. }\end{array}$ \\
\hline
\end{tabular}


Grupo 3 - Dados metodológicos do projeto

\begin{tabular}{|c|c|c|c|}
\hline $\begin{array}{l}\text { No. total } \\
\text { critérios }\end{array}$ & $\begin{array}{l}\text { No. de } \\
\text { critérios } \\
\text { p/grupo }\end{array}$ & Critérios de analise dos projetos & Descrição do critério \\
\hline 14 & 1 & $\begin{array}{l}\text { Qual a verdadeira missão, os } \\
\text { propósitos? (mitigar, } \\
\text { prospectar negócios ou } \\
\text { solucionar?) }\end{array}$ & $\begin{array}{l}\text { Os procedimentos metodológicos dos projetos validam as informações dos projetos que } \\
\text { normalmente estão no site ou nos briefings projetuais. Exemplo: o case da Portable light } \\
\text { (http://portablelight.org/), projeto do MIT, em parceria com a ADP BRASIL, operacionalizado por } \\
\text { ONG's brasileiras como a IDEAAS. Foi preciso uma entrevista com um dos parceiros para } \\
\text { compreender o verdadeiro propósito do projeto - prospecção de mercado/ Business. O que gerou } \\
\text { grande expectativa nas pessoas que foram usadas como público-alvo para o experimento. Não } \\
\text { resolveu, não mitigou, apenas experimentou. Foram distribuídos os kits, não havia manutenção do } \\
\text { kit e não havia planos de continuidade ou de troca por novos kits. Contudo a luminescência do kit } \\
\text { equivale a } 3 \text { velas acessas, o que não resolve o problema da ausência de energia local. O nome da } \\
\text { pessoa entrevistada não foi citado por solicitação do mesmo. Está disponível somente à banca de } \\
\text { defesa. }\end{array}$ \\
\hline 15 & 2 & $\begin{array}{l}\text { Quais os parâmetros e indicadores } \\
\text { utilizados? (Oficial statistical data) }\end{array}$ & $\begin{array}{l}\text { Este critério vai depender de como o projeto começou, com partiu a demanda. O que também vai } \\
\text { mudar de local para local. No Brasil eu citaria como parâmetro: o Índice de Desenvolvimento } \\
\text { Humano Nacional e Municipal, o IDH e o IDH-M, o IBGE - Instituto Brasileiro de Geografia e } \\
\text { Estatística, o Instituto de Pesquisa Econômica Aplicada (IPEA) e as próprias fontes delimitadas pelo } \\
\text { grupo de pesquisa de acordo com a especificidade do problema abordado. }\end{array}$ \\
\hline 16 & 3 & Quanto tempo de desenvolvimento? & Ė um critério para compreender o tempo médio de desenvolvimento deste tipo de projeto. \\
\hline 17 & 4 & $\begin{array}{l}\text { Ferramentas utilizadas para o } \\
\text { desenvolvimento (organização, }\end{array}$ & $\begin{array}{l}\text { Ter o conhecimento das maneiras que os grupos operacionalizaram suas práticas, identificar } \\
\text { ferramentas úteis e o perfil multidisciplinar de construção dos métodos. }\end{array}$ \\
\hline 18 & 5 & $\begin{array}{l}\text { Seguiram algum modelo de } \\
\text { desenvolvimento de produto/projetação } \\
\text { proposto pela literatura? Ou definiram pela } \\
\text { ousctã } n \text { nroinual? }\end{array}$ & $\begin{array}{l}\text { Compreender a realidade de demais grupos de designers quanto as suas referencias projetuais, ou } \\
\text { compreender como eles abordam suas metodologias projetuais. }\end{array}$ \\
\hline 19 & 6 & $\begin{array}{l}\text { Estão na lista de prioridades atender } \\
\text { fatores estéticos, simbólicos e culturais do } \\
\text { produto? }\end{array}$ & $\begin{array}{l}\text { Durante analises de campo sobre o Case desta tese, um servidora municipal relatou: as empresas } \\
\text { não entregam produtos de boa qualidade - se é para pobre não precisa. Gostaria de identificar a } \\
\text { opinião dos designers sobre o tema. }\end{array}$ \\
\hline
\end{tabular}


Grupo 5 - Pós-desenvolvimento e resultados do Projeto

\begin{tabular}{|c|c|c|c|}
\hline \multicolumn{4}{|c|}{ Grupo 5 - Pós-desenvolvimento e resultados do Projeto } \\
\hline $\begin{array}{l}\text { No. total } \\
\text { critérios }\end{array}$ & $\begin{array}{l}\text { No. de } \\
\text { critérios } \\
\text { p/ Grupo }\end{array}$ & Critérios de analise dos projetos & Descrição do critério \\
\hline 28 & 1 & Manufatura local? & $\begin{array}{l}\text { Este critério depende do foco projetual. Define se o projeto tem interesse no } \\
\text { desenvolvimento humano e local. Se há interesse em melhorias da qualidade vida da } \\
\text { população-alvo. Bem como no desafio da transformação da invenção para produto, ou seja } \\
\text { da tecnologia emergente (TE - inovação) para a transformação da tecnologia (TT) } \\
\text { (Tempelman et al, 2012) }\end{array}$ \\
\hline 29 & 2 & $\begin{array}{l}\text { Qual a estrutura organizacional que fornece } \\
\text { trabalho à comunidade: cooperativismo, } \\
\text { empregado de Empresa ou outros? }\end{array}$ & $\begin{array}{l}\text { Este critério depende do foco projetual. Define se o projeto tem interesse no } \\
\text { desenvolvimento humano e local. }\end{array}$ \\
\hline 30 & 3 & O projeto mitigou, aliviou ou resolveu o problema? & Este critério esta relacionado com o critério no. 1 do Grupo 3. \\
\hline 31 & 4 & Como o produto foi oferecido à comunidade? & $\begin{array}{l}\text { Compreender se o produto é vendido por uma empresa, distribuído gratuitamente por } \\
\text { políticas públicas, ONG's ou se é fabricado localmente pela comunidade e vendido seus } \\
\text { excedentes. }\end{array}$ \\
\hline 32 & 5 & Houve reaplicabilidade em outra região? & $\begin{array}{l}\text { Compreender como foram solucionadas as questões de escala projetual, os desafios, e } \\
\text { quais as soluções. }\end{array}$ \\
\hline 33 & 6 & $\begin{array}{l}\text { Qual foi a estratégia de continuidade para o } \\
\text { atendimento às necessidades da população-alvo? }\end{array}$ & $\begin{array}{l}\text { Este critério relaciona-se com o critério } 2 \text {, do Grupo } 2 \text {, quanto aos direitos humanos. Se o } \\
\text { projeto atendeu uma necessidade de atenção básica qual foi o papel do ator } \\
\text { governamental, enquanto política publica. Ou não foi considerado, por falta de interesse. }\end{array}$ \\
\hline
\end{tabular}


Grupo 4 - Dados sobre o desenvolvimento do produto

\begin{tabular}{|c|c|c|c|}
\hline $\begin{array}{l}\text { No. total } \\
\text { de } \\
\text { critérios }\end{array}$ & $\begin{array}{c}\text { No. de } \\
\text { critérios } \\
\text { p/Grupo }\end{array}$ & Critérios de analise dos projetos & Descrição do critério \\
\hline 20 & 1 & $\begin{array}{l}\text { Houve um padrão tecnológico (modelo) que } \\
\text { permitiu uma adequação sociotécnica com a } \\
\text { população-alvo? Ou foi desenvolvido somente } \\
\text { pela Universidade e seus parceiros sendo } \\
\text { apresentado para a população em protótipo para } \\
\text { experimento? }\end{array}$ & $\begin{array}{l}\text { Os princípios da tecnologia social prevê uma adequação sociotécnica (Dagnino, 2006) } \\
\text { (entre as propostas de tecnologia dos pesquisadores/cientistas e a comunidade para o qual estão } \\
\text { atendendo sua demanda. Nesse sentido deve-se cada parte contribuir com um ponto de partida o } \\
\text { cientista/pesquisador com uma base tecnológica, preview de um produto ou ideia, que deverá } \\
\text { ser aperfeiçoado junto com o grupo de pessoas. Da mesma forma a comunidade deverá munir o } \\
\text { grupo de cientistas/pesquisadores de conhecimentos } \\
\text { empírico-populares de suas realidades para a construção de um protótipo. A sociotecnia } \\
\text { desenvolve-se durante o PD da tecnologia. Não há adequação pós-desenvolvimento. Por isso } \\
\text { que a ferramenta que mais parecem apropriada foi a C.A. }\end{array}$ \\
\hline 21 & 2 & O protótipo foi desenvolvido por quem? & \multirow{4}{*}{$\begin{array}{l}\text { Este critério depende do foco projetual. Define se o projeto tem interesse no } \\
\text { desenvolvimento humano e local. Se há interesse em melhorias da qualidade vida da } \\
\text { população-alvo. } \\
\text { Este critério está vinculado ao propósito do projeto, se é apenas a entrega de um produto por } \\
\text { venda à população, situação que o indivíduo mantém distante de um processo de } \\
\text { desenvolvimento com liberdade (Sen, 2010). Não os permite desenvolver suas capacidades de } \\
\text { "ser e fazer" por si mesmos (Robeyns, 2006). }\end{array}$} \\
\hline 23 & 3 & Quem testou o protótipo? & \\
\hline 24 & 4 & Quanto tempo testou? & \\
\hline 25 & 5 & Quem e onde ocorreu o experimento? & \\
\hline 27 & 6 & $\begin{array}{l}\text { Principais desafios para ampliar os projetos em } \\
\text { escala de uso ao público-alvo? }\end{array}$ & $\begin{array}{l}\text { O artigo do case D.Light: Selling Solar to the poor (Case Stanford:IDE-03, 2012) comenta } \\
\text { dentre muitos desafios, mesmo que para uma empresa, a questão da logística de distribuição em } \\
\text { relação ao valor de venda. É preciso uma estrutura em cada local de mercado (INSEAD, 2007). } \\
\text { Outro desafio é a transformação da invenção para produto, ou seja, da tecnologia emergente } \\
\text { (TE - inovação) para a transformação da tecnologia (TT) (Tempelman et al, 2012) }\end{array}$ \\
\hline
\end{tabular}




\section{2. \\ APÊNDICE II - Questionário aplicado às Secretarias Municipais e Estaduais de Educação dos territórios estudados}

Questionário

1. A Prefeitura distribui uniformes escolares?

2. Caso haja distribuição: o que representa esta iniciativa para o município?

3. Caso não haja distribuição: porque?

4. Caso haja distribuição, quais os itens do kit de uniforme escolar?

5. A Prefeitura possui informação sobre a opinião das crianças e dos seus pais sobre o uso do uniforme escolar?

6. Se distribuem, a aquisição é realizada por licitação local ou pelo pregão nacional do FNDE?

7. Se distribuem, o tênis é um dos componentes do kit de uniforme escolar?

8. Poderiam falar sobre este produto em relação a realidade de uso das crianças?

9. Como é definido o modelo do tênis escolar?

10. Como é realizada a logística de entrega nas escolas?

11. Qual a frequência de pedidos, por escolas, para entrega do tênis?

12. Sobre a média de valor do tênis. 


\section{3.}

\section{APÊNDICE III - Pesquisa de campo realizada com alunos matriculados nas escolas públicas de São Paulo, Rio de Janeiro e Rio Grande do Sul (Período de 2008 a 2015)}

\begin{tabular}{|c|c|}
\hline \multicolumn{2}{|c|}{$\begin{array}{l}\text { ITENS CITADOS POR TODOS OS ALUNOS ENTREVISTADOS PARA A PERGUNTA: } \\
\text { QUE CALCADO VOCE DESEJA? } \\
\text { POR ORDEM DE IMPORTÂNCIA (MAIS VEZES CITADOS) } \\
\end{array}$} \\
\hline confortável & 45,58 \\
\hline bonito & 23,42 \\
\hline macio & 16,75 \\
\hline com amortecedor & 7,17 \\
\hline salto alto & 6,50 \\
\hline que seja bom & 6,50 \\
\hline muito confortável & 5,50 \\
\hline cor de rosa & 5,42 \\
\hline o meu tamanho_que sirva no meu pe & 4,78 \\
\hline cano longo & 3,83 \\
\hline barato & 3,58 \\
\hline desde que não machuque & 3,33 \\
\hline um tenis da nike & 3,33 \\
\hline que tenha sola macia & 3,00 \\
\hline cor vermelho & 2,87 \\
\hline um sapato que dure & 2,83 \\
\hline cor preta & 2,57 \\
\hline bico fino & 2,17 \\
\hline umas flores & 2,00 \\
\hline que nao seja apertado & 2,00 \\
\hline fofo & 2,00 \\
\hline cor rosa shock & 2,00 \\
\hline bem na moda de hoje & 1,92 \\
\hline colorido & 1,83 \\
\hline um solado duro & 1,75 \\
\hline com bastante brilho & 1,58 \\
\hline cor azul & 1,50 \\
\hline com boa qualidade & 1,42 \\
\hline lindo & 1,33 \\
\hline que entre no meu pé & 1,25 \\
\hline um simbolo de uma marca & 1,00 \\
\hline um simbolo da nike bem lindo! & 1,00 \\
\hline um sapato para escola & 1,00 \\
\hline um sapato lindo & 1,00 \\
\hline um pouco da cor cinza, rosa, azul, lilas & 1,00 \\
\hline um especial para skate & 1,00 \\
\hline quentinho & 1,00 \\
\hline que tivesse um som bem alto & 1,00 \\
\hline que seja radical & 1,00 \\
\hline que seja bom de usar & 1,00 \\
\hline para jogar basquete & 1,00 \\
\hline o que há de melhor & 1,00 \\
\hline Não QUERO & 1,00 \\
\hline EU TENHO UM TENIS DURO & 1,00 \\
\hline
\end{tabular}




\begin{tabular}{|c|c|}
\hline de jogar futebol & 1,00 \\
\hline de borracha firme & 1,00 \\
\hline cores do meu time & 1,00 \\
\hline cor laranja & 1,00 \\
\hline com rodinhas & 1,00 \\
\hline bom & 1,00 \\
\hline que seja do grêmio & 0,92 \\
\hline que não molhe os pés & 0,83 \\
\hline elegante & 0,75 \\
\hline cadarços na frente e pequenos & 0,75 \\
\hline que tenha cano & 0,58 \\
\hline de estilo & 0,58 \\
\hline tênis da bibi & 0,50 \\
\hline rasteirinho & 0,50 \\
\hline que vire um skate & 0,50 \\
\hline que tenha roda embaixo & 0,50 \\
\hline que tenha luz & 0,50 \\
\hline que seja do meu numero & 0,50 \\
\hline que seja ADDAN (marca de skate) & 0,50 \\
\hline que não entre água & 0,50 \\
\hline que faça barulho quando ande & 0,50 \\
\hline para jogar futebol & 0,50 \\
\hline palmilha macia & 0,50 \\
\hline delicado & 0,50 \\
\hline de menininha sabe? & 0,50 \\
\hline cor verde & 0,50 \\
\hline cor marrom e branco & 0,50 \\
\hline cor clara & 0,50 \\
\hline cor branco & 0,50 \\
\hline com tracos femininos & 0,50 \\
\hline com mola & 0,50 \\
\hline com fivelas & 0,50 \\
\hline bem bonito & 0,50 \\
\hline que seja baixo & 0,45 \\
\hline um de couro para ficar mais bonito & 0,33 \\
\hline tops, chadreizinhos, tirinhas & 0,33 \\
\hline salto plataforma bota & 0,33 \\
\hline que seja do $34-39$ & 0,33 \\
\hline que comum & 0,33 \\
\hline leve & 0,33 \\
\hline de camurça bota & 0,33 \\
\hline da adidas & 0,33 \\
\hline cor prata & 0,33 \\
\hline cor de rosa com branco & 0,33 \\
\hline como se não houvesse nada nos pés & 0,33 \\
\hline cheia de detalhes & 0,33 \\
\hline salto médio & 0,25 \\
\hline moderno & 0,25 \\
\hline apto para todo tipo de roupa & 0,20 \\
\hline salto rasteiro bota & 0,20 \\
\hline preços acessíveis & 0,20 \\
\hline legal & 0,20 \\
\hline
\end{tabular}




\begin{tabular}{|l|r|}
\hline de brim & 0,20 \\
\hline bem colado & 0,20 \\
\hline de verniz & 0,17 \\
\hline de marca legal & 0,17 \\
\hline da diadora & 0,17 \\
\hline
\end{tabular}

\subsection{1.}

\section{Organização dos itens citados por fatores de produto}

\begin{tabular}{|c|c|c|c|c|}
\hline & Constructo & Respostas & \multicolumn{2}{|c|}{ R. Final $\left(\%{ }^{*}\right)$} \\
\hline \multirow{18}{*}{ 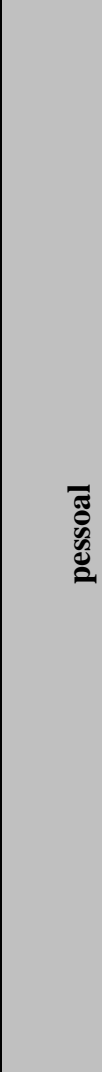 } & estético & bonito & 11,08 & \multirow{18}{*}{63,35748} \\
\hline & estético & cano longo & 9,80 & \\
\hline & estético & cor rosa shock & 5,11 & \\
\hline & estético & cor rosa & 3,83 & \\
\hline & estético & cor azul & 3,20 & \\
\hline & estético & cor preta & 3,07 & \\
\hline & estético & cor laranja & 2,56 & \\
\hline & estético & com fivelas & 1,28 & \\
\hline & estético & cor prata & 0,85 & \\
\hline & estético & de verniz & 0,43 & \\
\hline & estético/simbólico & bico fino & 5,54 & \\
\hline & estético/simbólico & lindo & 3,41 & \\
\hline & estético/simbólico & salto alto & 2,56 & \\
\hline & estético/simbólico & com mola & 1,28 & \\
\hline & estético/simbólico & cheia de detalhes & 0,85 & \\
\hline & simbólico & um tenis da nike & 5,11 & \\
\hline & simbólico & cores do meu time & 2,56 & \\
\hline & simbólico & um tenis da nike & 0,85 & \\
\hline \multirow{9}{*}{ 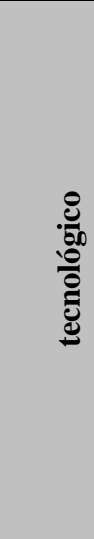 } & prático & confortavel & 19,17 & \multirow{9}{*}{36,64252} \\
\hline & prático & barato & 3,41 & \\
\hline & prático & que entre no meu pé & 3,20 & \\
\hline & prático & bom & 2,56 & \\
\hline & prático & de jogar futebol & 2,56 & \\
\hline & prático & para jogar basquete & 2,56 & \\
\hline & prático & rasteirinho & 1,28 & \\
\hline & prático & para jogar futebol & 1,28 & \\
\hline & prático & salto medio & 0,64 & \\
\hline Total & & & 100 & 100 \\
\hline
\end{tabular}


8.4.

\section{APENDICE IV - Análise sobre as especificações técnicas à forma do calçado, contidas na Norma referente a forma de calçados}

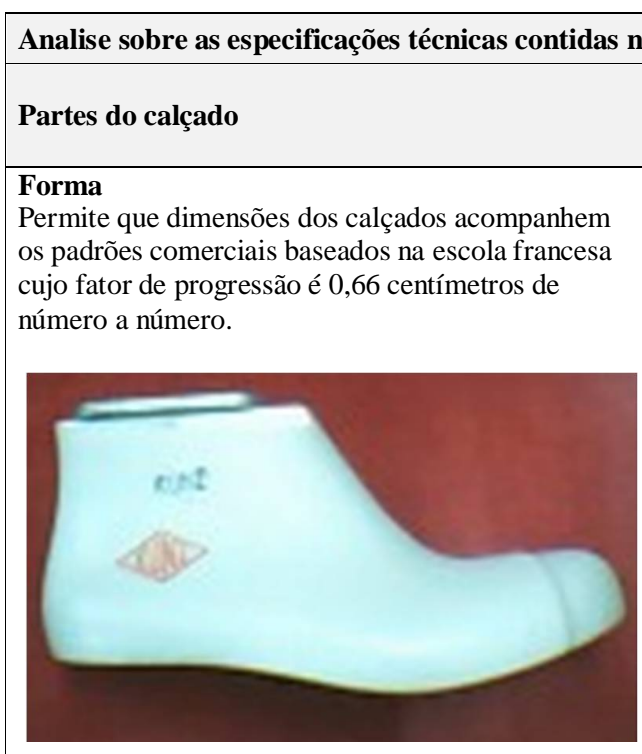

componentes - determinação dos diferentes perfis para o mesmo número - forma
comana

\begin{tabular}{|l}
$\begin{array}{l}\text { Itens citados pelos entrevistados sobre a } \\
\text { necessidade da forma }\end{array}$ \\
$\begin{array}{l}\text { Imprescindível para modelar o calçado porque é a } \\
\text { representação do pé humano - Antropometria. }\end{array}$ \\
$\begin{array}{l}\text { Ausência da forma na fabricação do calçado não } \\
\text { permite conformação, no termo popular signfica } \\
\text { "não selar". }\end{array}$ \\
\hline Se calçado de salto impossível fabricar sem form \\
\hline $\begin{array}{l}\text { uma coleção de forma para fabricação precisa } \\
\text { investimento financeiro, as empresas procuram } \\
\text { aproveitar.Se seguir moda tem que mudar a form }\end{array}$
\end{tabular}
entrevistados e as exigências da norma

Sim, é imprescindível para iniciar o projetação do calçado escolar.

No projeto de produto pode-se pensar alternativa de montagem na

manufatura. Considerar o pé humano como conformador do modelo.

O calçado escolar não tem salto alto, assemelham a modelos de tênis.

3. modelagem do solado; relaciona no momento de matricula;

2.Modelagem do calçado escolar;
Processos do sistema que se

1. Coleta dados Antropométricos

4. Apresentação do Protótipo 
8.5.

APÊNDICE V - Análise sobre as especificações técnicas sobre os modelos de tênis propostos pelo projeto da Norma referente

Analise sobre as especificações técnicas contidas na Norma referente aos modelos de tenis

\begin{tabular}{|c|c|c|c|}
\hline Partes do calçado & $\begin{array}{l}\text { Itens citados pelos entrevistados sobre o modelo } \\
\text { do tenis }\end{array}$ & $\begin{array}{l}\text { Comentários sobre a opinião dos } \\
\text { entrevistados e as exigências da norma }\end{array}$ & $\begin{array}{l}\text { Processos do sistema que se } \\
\text { relaciona }\end{array}$ \\
\hline \multirow{4}{*}{$\begin{array}{l}\text { O calçado deve se } \\
\text { injeção direta }\end{array}$} & $\begin{array}{l}\text { Calçado que tem como característica o grande } \\
\text { número de componentes. }\end{array}$ & \multirow{3}{*}{$\begin{array}{l}\text { O grande número de componentes exige: } \\
\text { controle do ciclo de vida de materiais diversos, } \\
\text { mais processos manuais para união das partes e } \\
\text { na reciclagem para desmontagem, o que não } \\
\text { garante aproveitamento de todos se estiverem } \\
\text { colados. }\end{array}$} & \multirow{5}{*}{$\begin{array}{l}\text { Todos os processos o que vai } \\
\text { depender do tipo de } \\
\text { montagem definida para o } \\
\text { modelo. }\end{array}$} \\
\hline & $\begin{array}{l}\text { Tem reforços e costuras na gáspea,colarinhos ou } \\
\text { linguetas e cadarços reforçados destinado } \\
\text { geralmente a atividades esportivas ou lazer. }\end{array}$ & & \\
\hline & $\begin{array}{l}\text { Dependendo de sua finalidade, encontrado com } \\
\text { diferentes alturas cano. }\end{array}$ & & \\
\hline & $\begin{array}{l}\text { Tipo de montagens diferentes o que determina } \\
\text { estética diferente. }\end{array}$ & $\begin{array}{l}\text { Tipo de montagem dificultam a reciclagem se } \\
\text { por injeção direta do solado, colado ou } \\
\text { vulcanizado (solado na cabedal). O tipo montado } \\
\text { com costura cabedal e solado contribui para } \\
\text { reciclagem. }\end{array}$ & \\
\hline Vulcanizado & & & \\
\hline
\end{tabular}


8.6.

\section{APÊNDICE VI - Análise sobre as especificações técnicas sobre o cabedal do calçado escolar contidas no Projeto da} Norma

Analise sobre as especificações técnicas contidas na Norma referente

as partes que compõem um tênis escolar

Partes do calçado

Comentários sobre a as

Cabedal

Parte superior do calçado.

Determinação da permeabilidade ao No mínimo, $0,8 \mathrm{mg} /\left(\mathrm{cm}^{2} . \mathrm{h}\right)$

Poderá ser composto por gáspea, traseiro, biqueira e lingueta, estes itens deverão ser

fabricados em material têxtil, sintético ou couro.

Construção superior do vapor d'água. $\mathrm{O}$ ensaio deve ser

efetuado em corpos-de-prova

constituídos pelo cabedal e o

forro na forma em que estão

unidos no calçado).

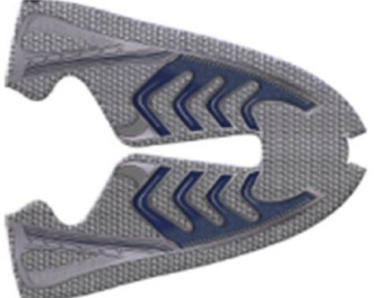

O ensaio deve ser efetuado em corpos-de-prova constituídos pelo cabedal e o forro na forma em que estão unidos no calçado).

1 item: Gáspea (pode ter mais itens depende do desenho)

Feito em alta frequência, visão superior aberto.

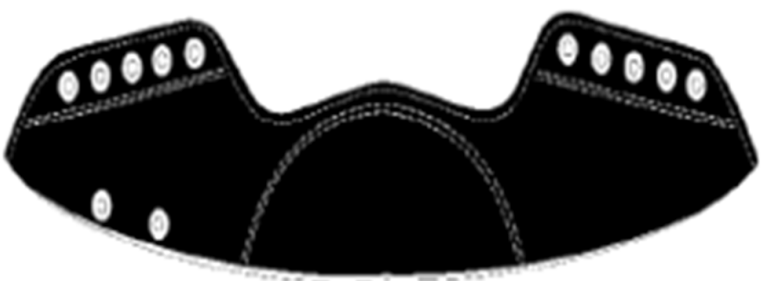

Montado manualmente, com visao do traseiro e fechamento em ilhoses.

Quando montado com várias partes possibilidade de reaproveitamento de retalhos e amplia cartela de composições estilísticas cores/texturas.

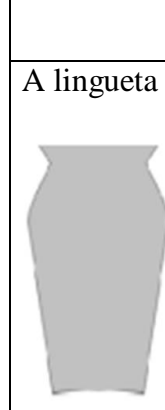

proporcionar conforto e proteção aos pés no calce. exigências da norma

È imprescindível.

Maior custo de processo

montagem e desmontagem.

Quando montado com

menos partes maior custo

no uso do material, mas

menos processo humano

montagem e desmontagem.

Maior possibilidade de reciclagem.

Dependendo do modelo do tênis a modelagem não precisa considerar lingueta. O que já exclui mais uma parte no calçado e

processos, uso de material e resíduo. 


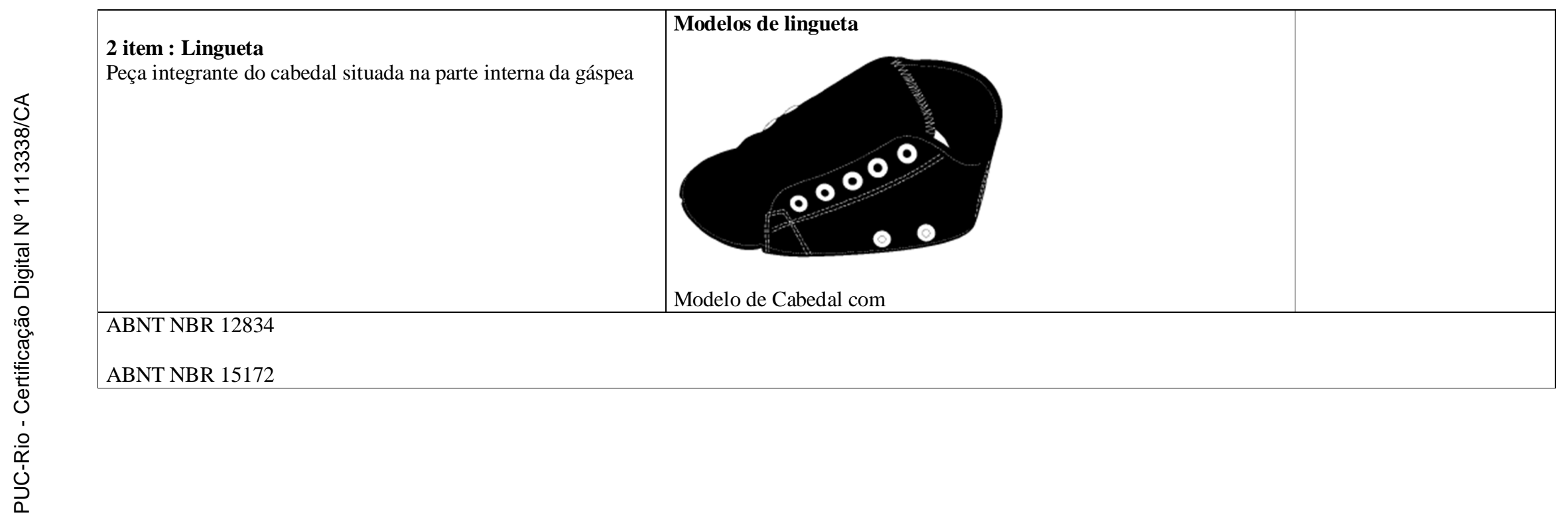




\section{7.}

\section{APÊNDICE VII - Análise sobre as especificações técnicas sobre a estrutura do cabedal - couraça, contra-forte e forro, contidas no Projeto da Norma}

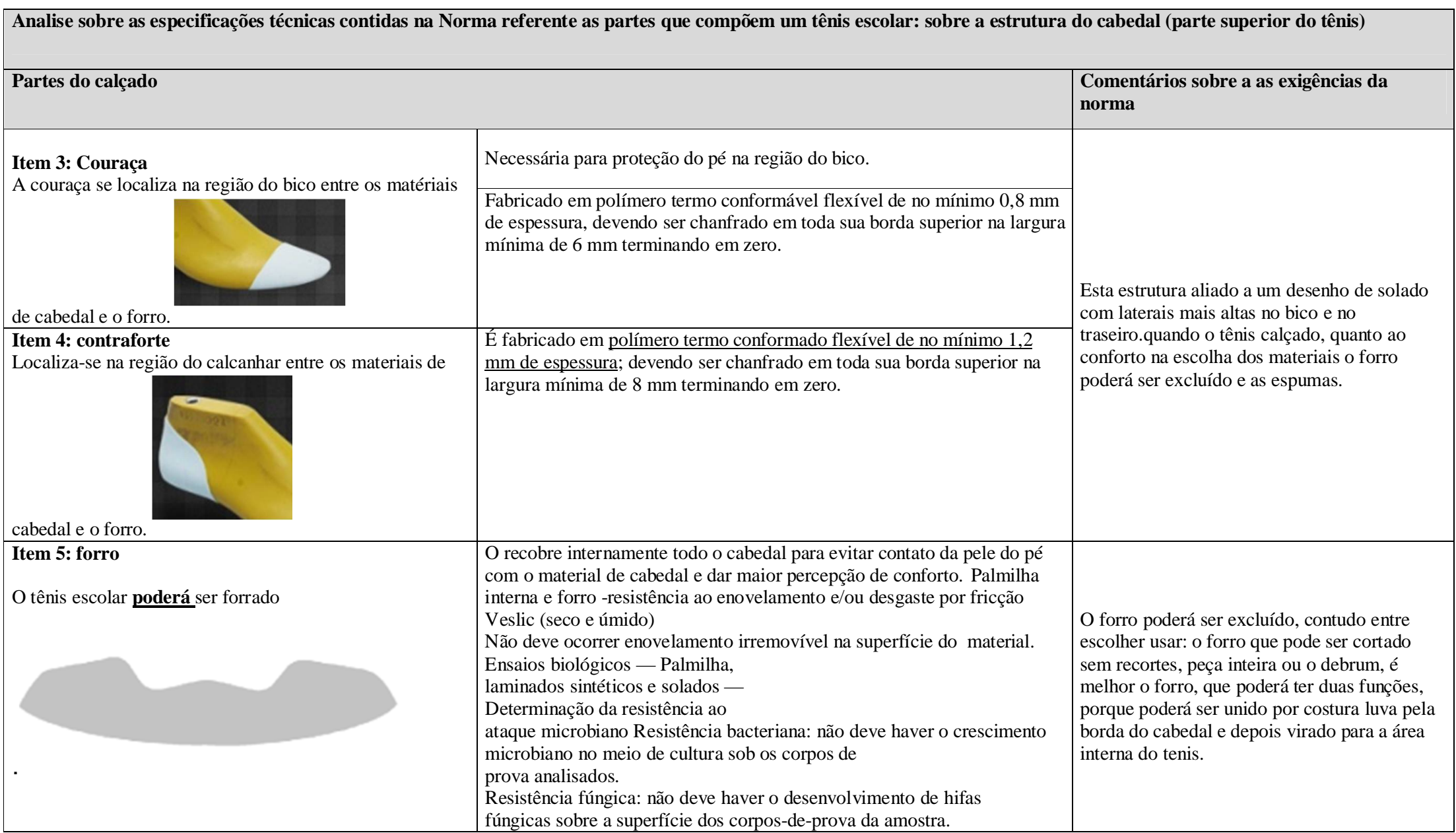




\begin{tabular}{|l|l|l|l|}
\hline $\begin{array}{l}\text { Item 6: debrum } \\
\text { Caso o modelo use o debrum, deverá ser de viés para as } \\
\text { bordas não desfiarem. Na mesma cor do cabedal. Caso o } \\
\text { modelo não use outro tipo de acabamento deverá ser usado } \\
\text { para que não fiquem à fio. }\end{array}$ & $\begin{array}{l}\text { Caso o modelo use o } \\
\text { debrum, o mesmo deverá ser de viés com largura mínima de } 12 \mathrm{~mm} \text { e com } \\
\text { bordas que não desfiam. Na mesma cor do cabedal. }\end{array}$ \\
\cline { 2 - 4 } & & $\begin{array}{l}\text { As bordas para que não fiquem à fio sem contenção para não desfiarem ou } \\
\text { sofrer alargamento }\end{array}$ \\
\hline
\end{tabular}


8.8.

\section{APÊNDICE VIII - Análise sobre as especificações técnicas sobre a montagem do cabedal (parte superior do tênis) contidas no Projeto da Norma}

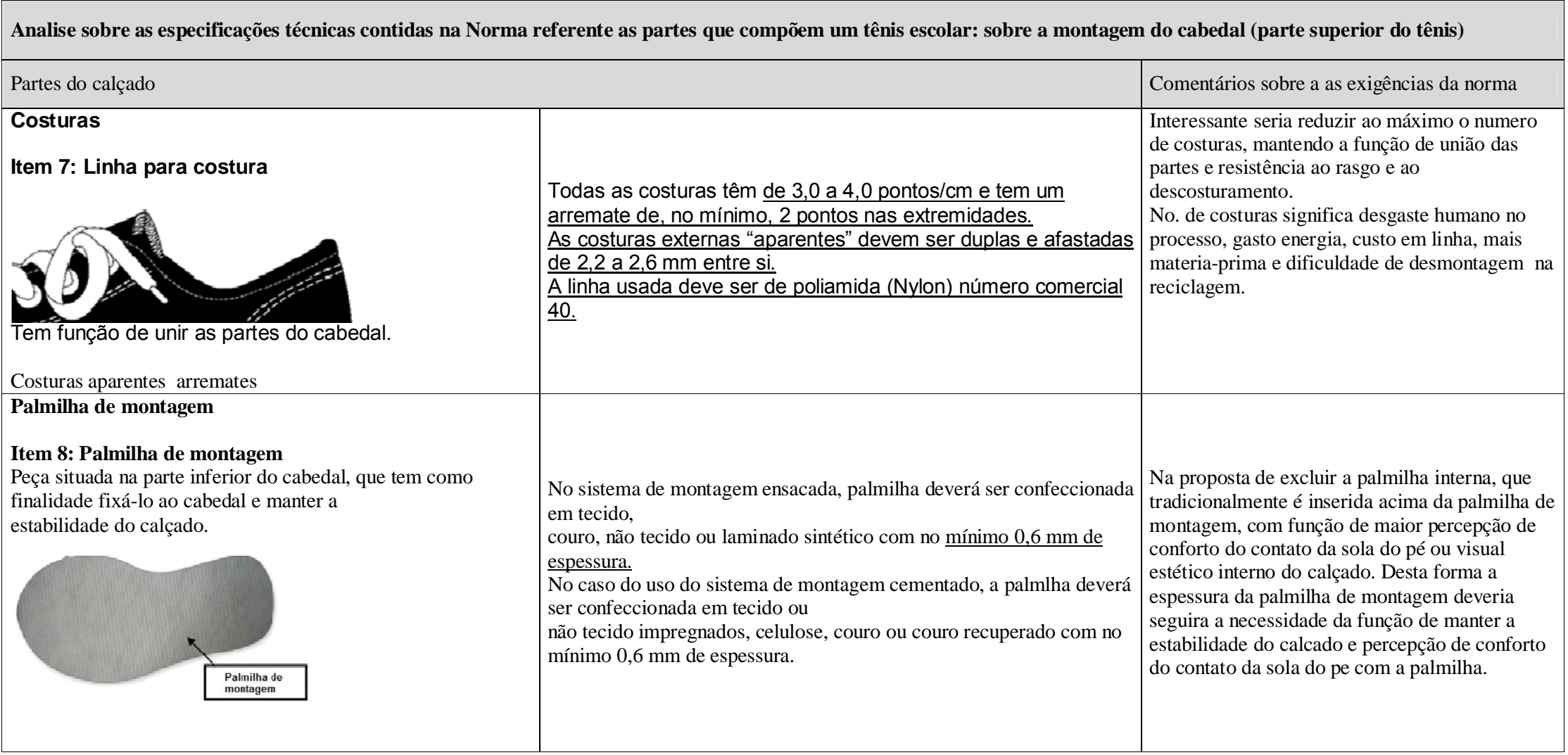




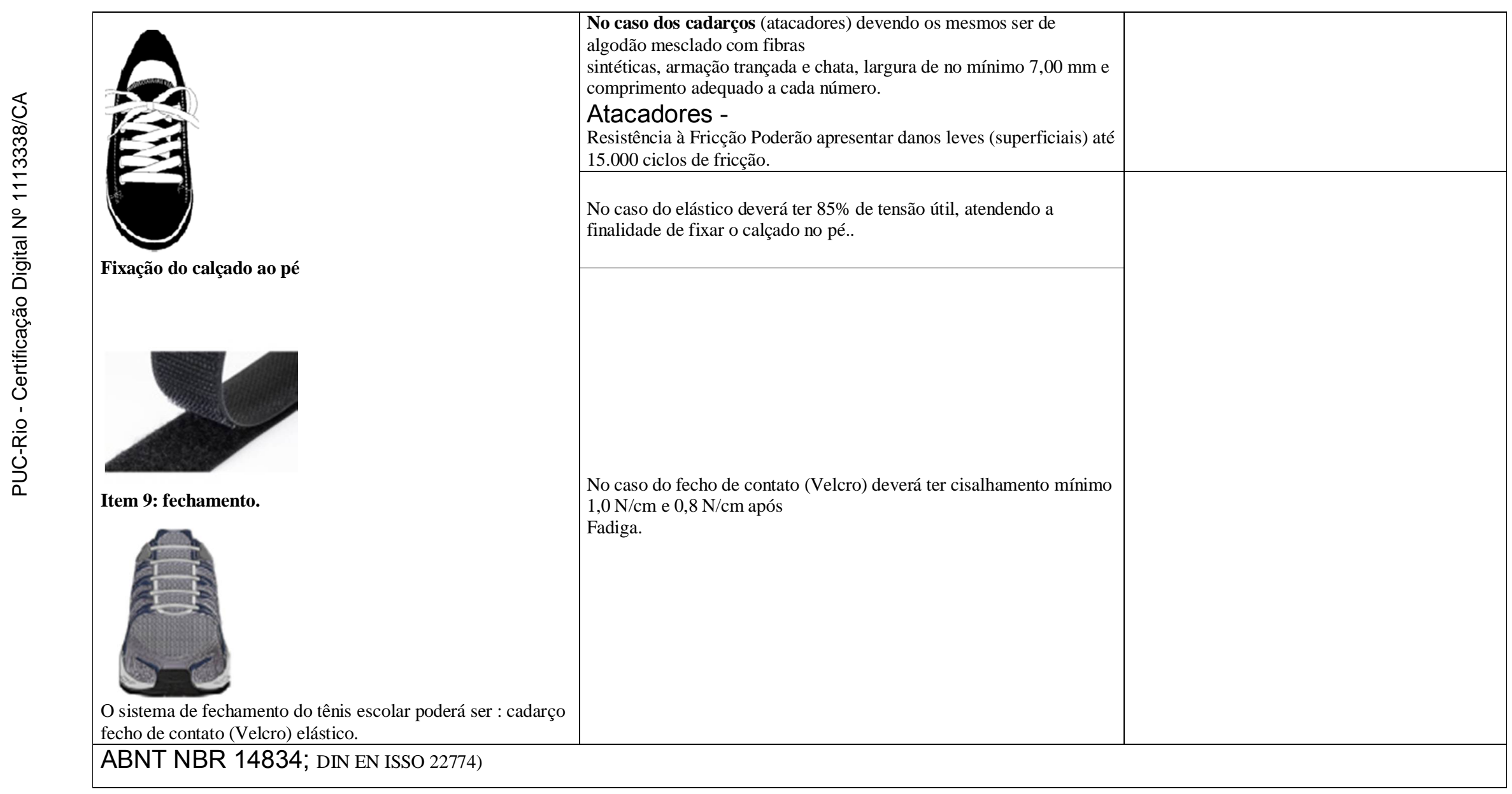

